\title{
Urban Airshed Modeling of Air Quality Impacts of Alternative Transportation Fuel Use in Los Angeles and Atlanta
}

Earth Technology, Inc.

Concord, Massachusetts

NREL Technical Monitors: Paul Bergeron and Michelle Bergin
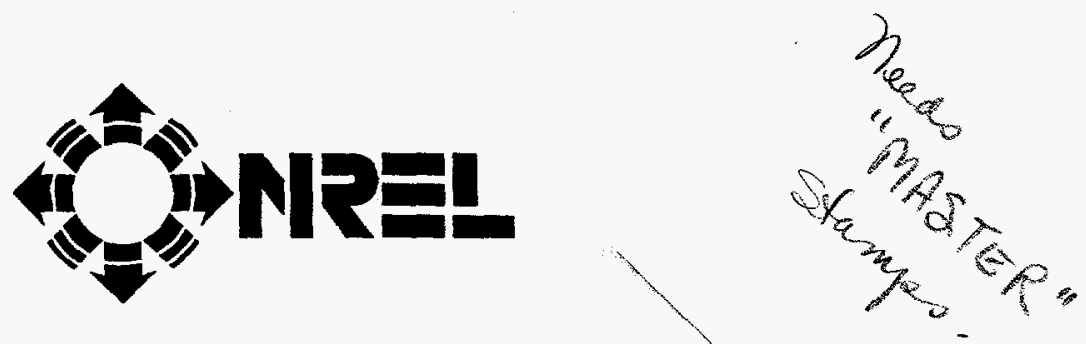

Alternative Fuels Hotline: 1-800-423-1DOE

Alternative Fuels Data Center World Wide Web Site: http://www. afa

National Renewable Energy Laboratory

1617 Cole Boulevard

Golden, Colorado 80401-3393

A national laboratory of the

U.S. Department of Energy

Managed by the Midwest Research Institute

For the U.S. Department of Energy

Under Contract No. DE-AC36-83CH10093

Prepared under Subcontract Number ACl-7-17013-01

December 1997 
This putlication was reproduced from the best available camera-seady copy submitte 1 by the subcontractor and received no editorial review at NREL

\section{NOTICE}

This report was prepared as an account of work sponsored by an agency of the United States govemment. Neither the United States go'vemment nor any agency thereof, nor any of their employees, makes any warranty, express or implied, cr assumes any legal liability or responsibility for the accuracy, completeness, or usefulness of any information, apparatus, product, or process disclosed, or represents that its use would not infringe privately owned rigrts. Reference herein to any specific commercial product, process, or service by trade name, trademark, manufacturer, or otherwise does not necessarily consitute or imply its endorsement, recommendation, or favoring by the United States government or any agency thereof. The views and opinions of authors expressed herein do not necessarily state or reflect those of the United States government or any agency thireof.

Available to DOE and DOE contractors from:

Office of Scientific and Technical Information (OSTI)

P.O. Box 62

Oak Ridge, TN 37831

Pricus available by calling (423) $576-8401$

Available to the public from:

National Technical Information Service (NTIS)

U.S. Department of Commerce

5285 Port Royal Road

Springfield, VA 22161

(703) 487-4650 


\section{DISCLAMIER}

Portions of this document may be illegible in electronic image produets. Images are produced from the best available origion docomenter. 


\section{TABLE OF CONTENTS}

Page

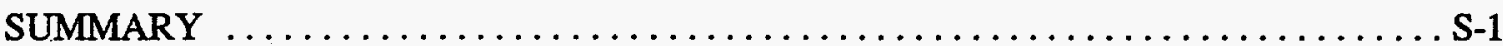

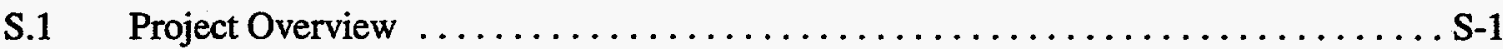

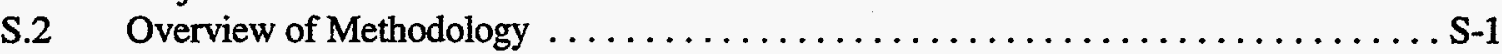

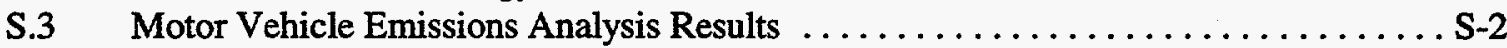

S.4 Development of Toxics CBM-IV Chemical Mechanism ...............

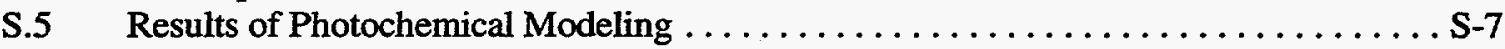

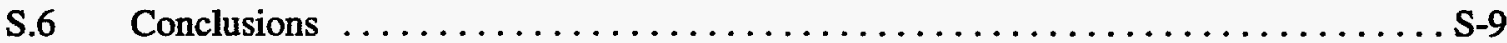

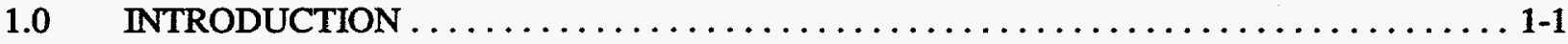

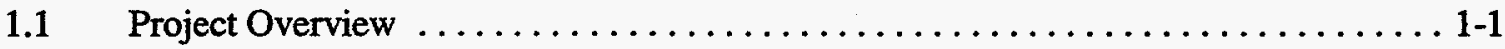

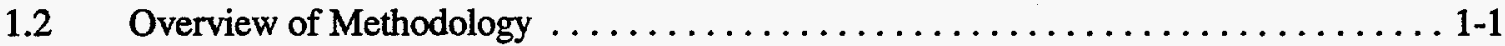

1.3 Overview of Photochemical Modeling Methodology ................. 1-2

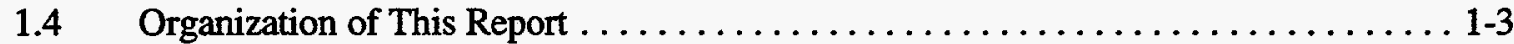

2.0 MOTOR VEHICLE EMISSIONS ANALYSIS $\ldots \ldots \ldots \ldots \ldots \ldots \ldots \ldots \ldots \ldots \ldots \ldots \ldots \ldots \ldots$

2.1 Future Year Motor Vehicle Scenario Definition $\ldots \ldots \ldots \ldots \ldots \ldots \ldots \ldots \ldots . . \ldots \ldots$

2.2 Overview of Motor Vehicle Emissions Analysis Methodology . . . . . . . . . . 2-2

2.3 Summary of Motor Vehicle Emission Analysis Results ................ 2-3

2.4 Emission Estimates for Greenhouse Gases and Air Toxics $\ldots \ldots \ldots \ldots \ldots \ldots \ldots \ldots$

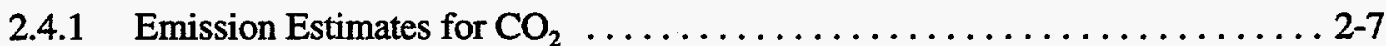

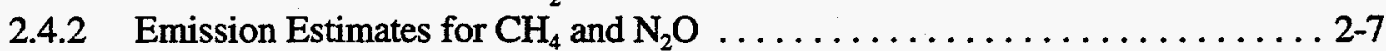

2.4.3 Emission Estimates for Air Toxics ..................... 2-9

3.0 DEVELOPMENT AND TESTING OF A TOXICS CBM-IV CHEMICAL

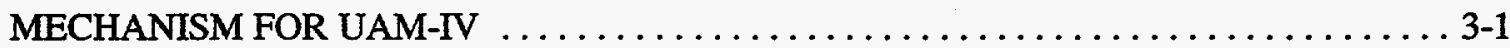

3.1 Modifications of the CBM-IV Surrogate Approximation $\ldots \ldots \ldots \ldots \ldots \ldots \ldots \ldots .1$

3.2 Testing of the CBM-IV Toxics Chemical Mechanism $\ldots \ldots \ldots \ldots \ldots \ldots \ldots \ldots \ldots \ldots \ldots$

4.0 MODEL SETUP AND QUALITY ASSURANCE FOR LOS ANGELES $\ldots \ldots \ldots \ldots \ldots 4-1$

4.1 Modeling Scenario and Sources of Model Inputs . . . . . . . . . . . . .

4.2 Modification of Initial Input Data Sets for Toxic Compounds . . . . . . . . . . 4-2

4.3 Evaluation of Base Case Simulation without Air Toxics $\ldots \ldots \ldots \ldots \ldots \ldots \ldots . . \ldots \ldots$

4.4 Comparison of Base Year with and without Toxic Compound

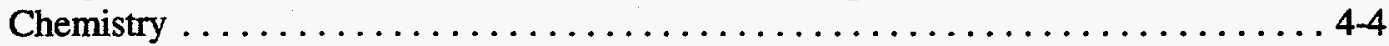

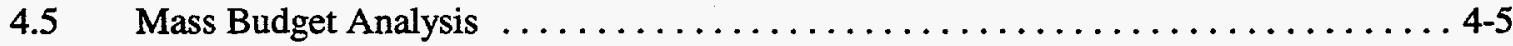




\section{TABLE OF CONTENTS (Concluded)}

5.0 MODEL SETUP AND QUALITY ASSURANCE FOR ATLANTA $5-1$

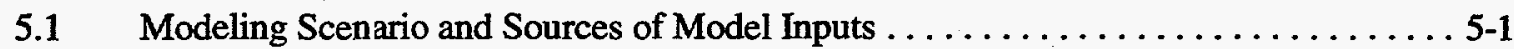

5.2 Modification o: Initial Input Data Sets for Toxic Compounds . . . . . . . . . . . 5-2

5.3 Evaluation of Eiase Run without Air Toxics .................... 5-3

5.4 Comparison of Base Run with and without Toxic Compound

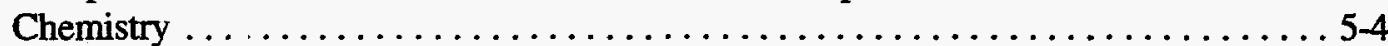

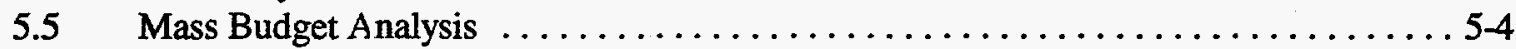

6.0 ANALYSIS OF FUTURE YEAR MODELING RESULTS FOR LOS ANGELES

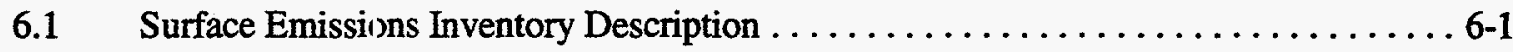

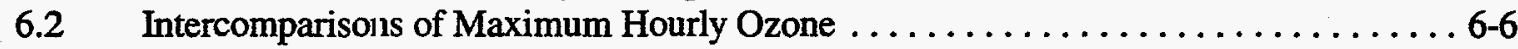

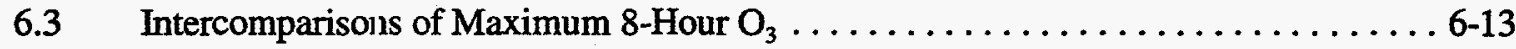

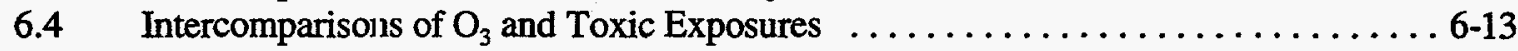

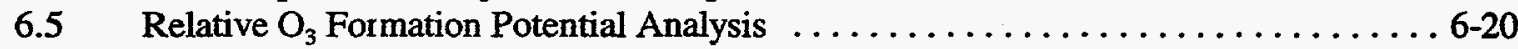

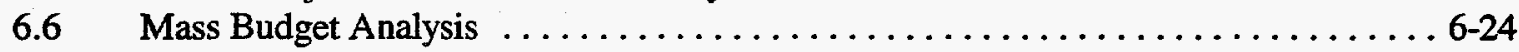

7.0 ANALYSIS OF FUTUIRE-YEAR MODELING RESULTS FOR ATLANTA $\ldots \ldots \ldots \ldots 7-1$

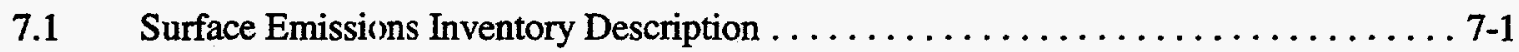

7.2 Intercomparisons of Daily Maximum Hourly $\mathrm{O}_{3} \ldots \ldots \ldots \ldots \ldots \ldots \ldots \ldots$

7.3 Intercomparisons of Daily Maximum 8-Hour Ozone $\ldots \ldots \ldots \ldots \ldots \ldots \ldots \ldots \ldots .7 .13$

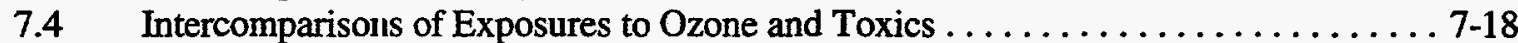

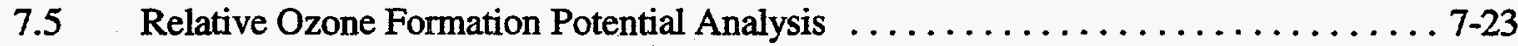

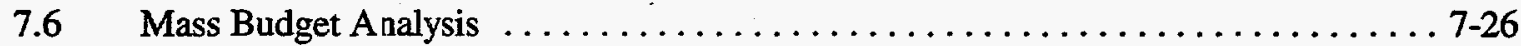




\section{LIST OF FIGURES}

Page

3-1 BOXCHEM comparison of CBM-IV, Base, and Toxics mechanisms for midday simulation . 3-13

4-1 Comparison of daily maximum 1-hour surface $\mathrm{O}_{3}$ concentrations for 27 August

for SCAQMD simulation (isopleths in pphm) and QA1 simulation (tiles in ppb) . . . . . 4-6

4-2 Comparison of daily maximum 1-hour surface $\mathrm{O}_{3}$ concentrations for 28 August

for SCAQMD simulation (isopleths in pphm) and QA1 simulation (tiles in ppb) . . . . . 4-7

4-3 Hourly observed and predicted 1-hour surface ozone concentrations at Azusa

(top) and Norco (bottom) for 27-28 August 1987 AQMP episode . . . . . . . . . . . . . . 4-8

4-4 Daily maximum 1-hour surface $\mathrm{O}_{3}$ concentrations for Los Angeles for 27 August for QA1 (Base) and QA2 (Air Toxics) QA simulations . . . . . . . . . . . . 4-9

4-5 Daily maximum 1-hour surface $\mathrm{O}_{3}$ concentrations for Los Angeles for 28 August for QA1 (Base) and QA2 (Air Toxics) QA simulations . . . . . . . . . . . . 4-10

4-6 Difference in daily maximum 1-hour surface $\mathrm{O}_{3}$ concentrations for Los Angeles for 27 August for QA1 (Base) minus QA2 (Air Toxics) QA simulations . . . . . . . . 4-11

4-7 Difference in daily maximum 1-hour surface $\mathrm{O}_{3}$ concentrations for Los Angeles for 28 August for QA1 (Base) minus QA2 (Air Toxics) QA simulations . . . . . . . . 4-12

4-8 Daily maximum 1-hour surface VOC concentrations for Los Angeles for 28 August for QA1 (Base) and QA2 (Air Toxics) QA simulations ............. 4-13

4-9 Daily maximum 1-hour surface $\mathrm{NO}_{\mathrm{x}}$ concentrations for Los Angeles for 28 August for QA1 (Base) and QA2 (Air Toxics) QA simulations .............. 4-14

4-10 Daily maximum 1-hour surface formaldehyde (FORM) concentrations for Los Angeles for 28 August for QA1 (Base) and QA2 (Air Toxics) QA simulations . . . . . 4-15

5-1 Comparison of daily maximum 1-hour $\mathrm{O}_{3}$ concentrations for 30 July for

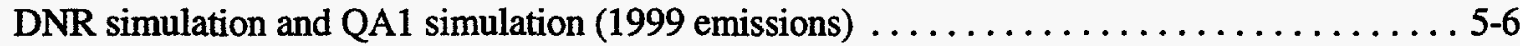

5-2 Comparison of daily maximum 1-hour $\mathrm{O}_{3}$ concentrations for 31 July for

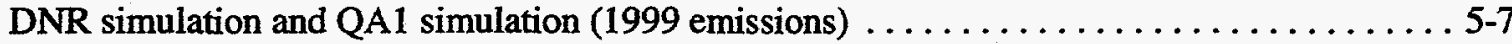

5-3 Comparison of daily maximum 1-hour surface $\mathrm{O}_{3}$ concentrations for 30 July for Atlanta for QA1 (Base) and QA2 (Air Toxics) QA

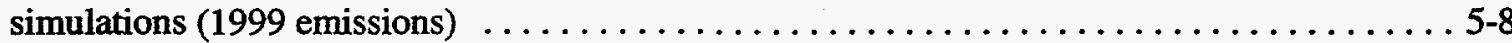

5-4 Comparison of daily maximum 1-hour surface $\mathrm{O}_{3}$ concentrations for $31 \mathrm{July}$ for Atlanta for QA1 (Base) and QA2 (Air Toxics) simulations (1999 emissions) . . . . . . . . . 5-9

5-5 Hourly predicted 1-hour surface ozone concentrations at MLK MARTA (top) and Dawsonville (bottom) for 30-31 July 1987 for QA1 (Base) and QA2 (Air Toxics) simulations

5-6 Difference in daily maximum 1-hour surface $\mathrm{O}_{3}$ concentration for Atlanta for 30 July for QA1 (Base) minus QA2 (Air Toxics) QA

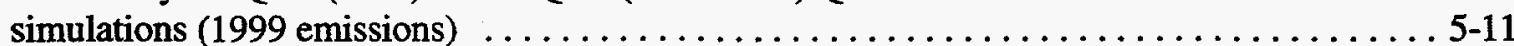

5-7 Difference in daily maximum 1-hour surface $\mathrm{O}_{3}$ concentration for Atlanta for 31 July for QA1 (Base) minus QA2 (Air Toxics) QA simulations (1999 emissions) 


\section{LIST OF FIGURES (Continued)}

5-8 Daily maximum 1-hour surface VOC concentrations for Atlanta for 31 July for QA1 (Base) and QA.2 (Air Toxics) QA simulations (1999 emissions) . . . . . . . . . 5-13

5-9 Daily maximum 1-hour surface $\mathrm{NO}_{\mathrm{x}}$ concentrations for Atlanta for 31 July for QA1 (Base) and QA.2 (Air Toxics) QA simulations (1999 emissions) . . . . . . . . . 5-14

5-10 Daily maximum 1-hour surface FORM concentrations for Atlanta for 31 July for QA1 (Base) and QA2 (Air Toxics) QA simulations (1999 emissions) . . . . . . . 5-15

6-1 Daily VOC and $\mathrm{NO}_{x}$ enission density plots with on-road light- and medium-duty vehicle ernissions removed for Los Angeles for 28 August 2007 . . . . . . . . 6-3

6-2 Diurnal trend in $\mathrm{NO}_{\mathrm{x}}$ and VOC emissions for Los Angeles by emission

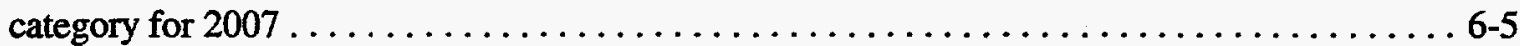

6-3 Daily VOC emission density plots for CNG and RFG scenarios for

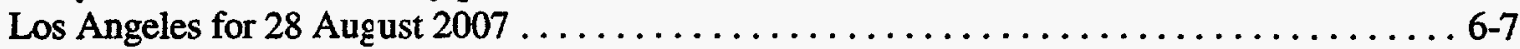

6-4 Daily $\mathrm{NO}_{x}$ emission density plots for CNG and RFG scenarios for

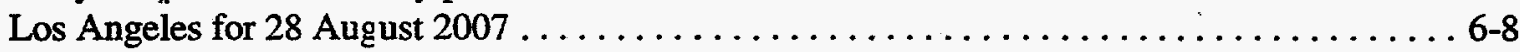

6-5 Daily maximum 1-hour $\mathrm{O}_{3}$ concentrations with and without on-road motor vehicles for the RFG scinario for Los Angeles for 27 August 2007

6-6 Daily maximum 1-hour $\mathrm{O}_{3}$ concentrations with and without on-road motor vehicles for the RFG scienario for Los Angeles for 28 August 2007

6-7 Daily maximum 1-hour $\mathrm{O}_{3}$ concentrations for $\mathrm{RFG}$ and $\mathrm{CNG}$ scenarios for Los Angeles for 27 August 2007 .

6-8 Daily maximum 1-hour $\mathrm{O}_{3}$ concentrations for RFG and CNG scenarios for

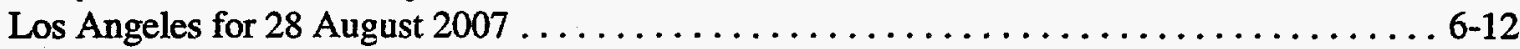

6-9 Daily maximum 1-hour VOC concentrations for RFG and CNG scenarios for

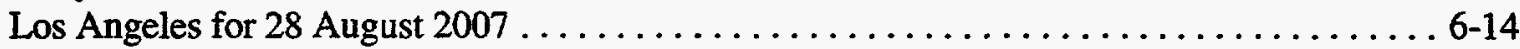

6-10 Daily maximum 1-hour $\mathrm{NO}_{\mathrm{x}}$ concentrations for RFG and CNG scenarios for

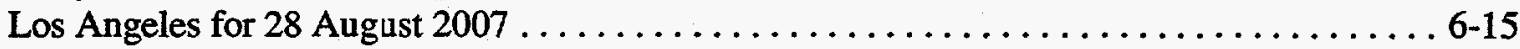

6-11 Daily maximum 8-hour $\mathrm{O}_{3}$ concentration for $\mathrm{RFG}$ and $\mathrm{CNG}$ scenarios for

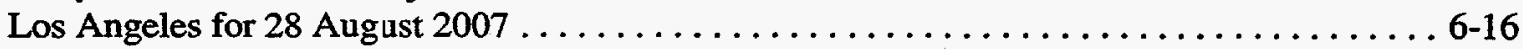

6-12 Population density in $L c s$ Angeles area for $1990 \ldots \ldots \ldots \ldots \ldots \ldots \ldots \ldots \ldots \ldots \ldots \ldots \ldots$

6-13 Cumulative $\mathrm{O}_{3}$ exposure for RFG and $\mathrm{CNG}$ scenarios for Los Angeles

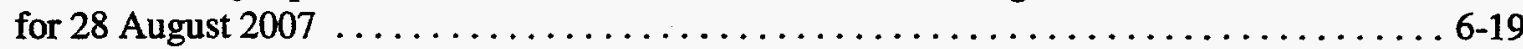

6-14 Cumulative FORM exposure for RFG and CNG scenarios for Los Angeles for 28 Aug ast 2007

7-1 Daily Atlanta VOC and $\mathrm{NO}_{\mathrm{x}}$ emissions density plot for 2007 with on-road

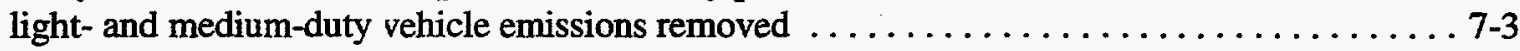

7-2 Diurnal trend in $\mathrm{NO}_{x}$ ani VOC emissions for Atlanta by ennission category

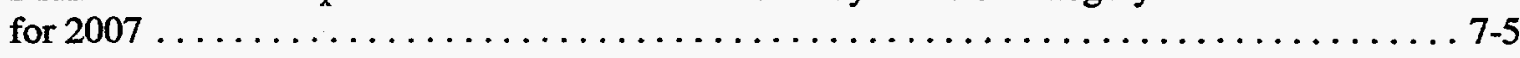

7-3 Spatial pattern of daily VOC emissions in Atlanta for 31 July 2007 CNG and RFG scenario: . . . . . . . . . . . . .

7-4 Spatial pattern of daily $\mathrm{NO}_{\mathrm{x}}$ emissions in Atlanta for 31 July 2007

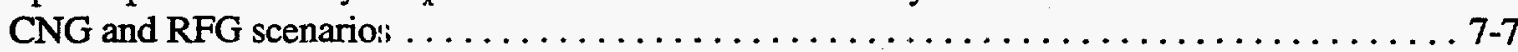

7-5 Daily maximum 1-hour $\mathrm{O}_{3}$ concentrations with and without on-road motor vehicles for Atlanta for 30 July 2007 RFG scenario 


\section{LIST OF FIGURES (Concluded)}

7-6 Daily maximum 1-hour $\mathrm{O}_{3}$ concentrations with and without on-road motor vehicles for Atlanta for 31 July 2007 RFG scenario $\ldots \ldots \ldots \ldots \ldots \ldots \ldots \ldots \ldots \ldots$

7-7 Daily maximum 1-hour $\mathrm{O}_{3}$ concentrations with and without on-road motor vehicles for Atlanta for 30 July 2007 for CNG scenario . . . . . . . . . . . . 7-11

7-8 Daily maximum 1-hour $\mathrm{O}_{3}$ concentrations with and without on-road motor vehicles for Atlanta for 31 July 2007 for CNG scenario . . . . . . . . . . . . . 7-12

7-9 Daily maximum 1-hour surface VOC concentrations for Atlanta

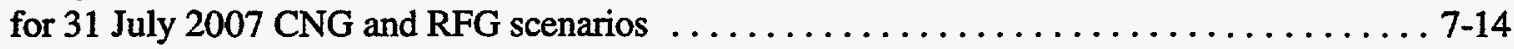

7-10 Daily maximum 1-hour surface $\mathrm{NO}_{x}$ concentrations for Atlanta

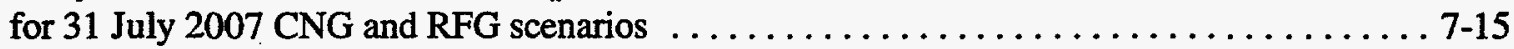

7-11 Daily maximum 8-hour surface $\mathrm{O}_{3}$ concentrations for Atlanta for 30 July $2007 \mathrm{CNG}$ and RFG scenarios .......................... 7-16

7-12 Daily maximum 8-hour surface $\mathrm{O}_{3}$ concentrations for Atlanta

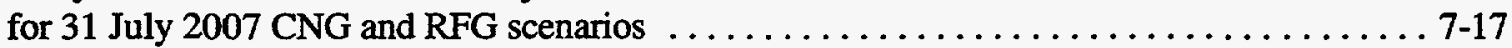

7-13 Population density in the Atlanta modeling domain for $1990 \ldots \ldots \ldots \ldots \ldots \ldots \ldots \ldots$. 19

7-14 Cumulative surface $\mathrm{O}_{3}$ exposures for Atlanta for 31 July 2007

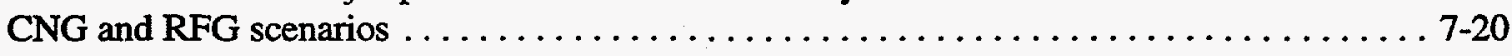

7-15 Cumulative surface FORM exposures for Atlanta for 31 July 2007 CNG and RFG scenarios $\ldots \ldots \ldots \ldots \ldots \ldots \ldots \ldots \ldots \ldots \ldots \ldots \ldots \ldots \ldots \ldots \ldots \ldots \ldots .22$

7-16 Estimated daily average VOC: $\mathrm{NO}_{x}$ concentration ratios for Atlanta for 31 July 2007 CNG and RFG scenarios 


\section{LIST OF TABLES}

Page

S-1 Criteria, Toxic, and Greenhouse Gas Pollutants for Which Emission Estimates

Were Developed for Allernative Fuel Vehicles . . . . . . . . . . . . . . . . . . S 1

S-2 Estimated Light- and Medium-Duty Fleet Composite Average Exhaust Emission

Factors for FTP Operation for Year 2007, Average Summer Day . . . . . . . . . . . S-3

S-3 Exhaust Emission Adju stment Factors for Atlanta for Year $2007 \ldots \ldots \ldots \ldots \ldots \ldots \ldots \ldots$. . . . . .

S-4 Exhaust Emission Adju stment Factors for Los Angeles for Year $2007 \ldots \ldots \ldots \ldots \ldots$. . . S-5

S-5 Greenhouse Gas Emissions from Light- and Medium-Duty

Vehicles for Alternative Fuel Scenarios for $2007 \ldots \ldots \ldots \ldots \ldots \ldots \ldots \ldots \ldots \ldots \ldots$. $6 \ldots \ldots$

S-6 Air Toxic Emissions frcm Light- and Medium-Duty Vehicles for

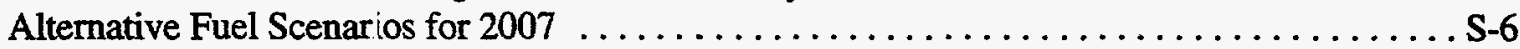

1-1 Criteria, Toxic, and Greenhouse Gas Pollutants for which Emission Estimates

Were Developed for Allernative Fuel Vehicles . . . . . . . . . . . . . . . . . . 1-1

2-1 Estimated Light- and Medium-Duty Fleet Composite Average Exhaust Emission

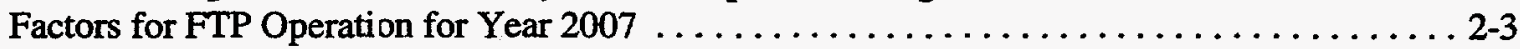

2-2 Exhaust Emission Adjuistment Factors for Atlanta for Year $2007 \ldots \ldots \ldots \ldots \ldots \ldots \ldots \ldots$. $\ldots \ldots$

2-3 Exhaust Emission Adjuistment Factors Los Angeles for Year $2007 \ldots \ldots \ldots \ldots \ldots \ldots \ldots$

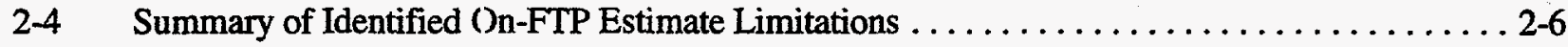

2-5 Summary of Identified (Off-FTP Estimate Limitations $\ldots \ldots \ldots \ldots \ldots \ldots \ldots \ldots \ldots \ldots \ldots$

2-6 Estimated Fuel Usage, Finergy Usage, Carbon Emission Factors and $\mathrm{CO}_{2}$

Emission Rates for Los Angeles and Atlanta for Year 2007 for Light-

and Medium-Duty Gasoline- and CNG-Fueled Vehicles $\ldots \ldots \ldots \ldots \ldots \ldots \ldots \ldots \ldots \ldots$

2-7 Estimated $\mathrm{CH}_{4}$ and $\mathrm{N}_{2} \mathrm{O}$ Emissions from Affected On-Road Mobile Sources in

Los Angeles (tons/day) . . . . . . . . . . . . .

2-8 Estimated $\mathrm{CH}_{4}$ and $\mathrm{N}_{2} \mathrm{O}$ Emissions from Affected On-Road Mobile Sources in

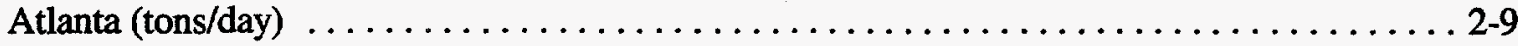

2-9 Estimated Air Toxic Emissions from Affected On-Road Mobile Sources in

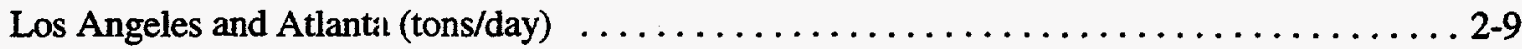

3-1 Chemical Species in the Toxics Version of the CBM-IV Mechanism . . . . . . . . . . . 3-3

3-2 The Toxics Version of the Carbon Bond Mechanism IV $\ldots \ldots \ldots \ldots \ldots \ldots \ldots \ldots \ldots .5$

3-3 Final Predicted Concentrations for the Major Nitrogen Species from the 6-Hour Daytime

BOXCHEM Simulation CBM and TOXIC (units are ppm) . . . . . . . . . . $3-12$

4-1 A Summary of Los Angeles Modeling Domain Characteristics . . . . . . . . . . . . 4-1

4-2 Summary of Input Data Sources for the Los Angeles Episode . . . . . . . . . . . . 4-2

4-3 Summary of Major Sources and Sinks of the Toxic Chemicals in the

Los Angeles Modeling Iomain for the Base Year (1987) . . . . . . . . . . . . . 4-3

4-4 Summary of the Chemical Production of $\mathrm{O}_{3}$ and Other Chemicals over

the Period 27-28 August in the Los Angeles Modeling Donnain . . . . . . . . . . . . 4-5

5-1 Summary of Atlanta Modeling Domain Characteristics $\ldots \ldots \ldots \ldots \ldots \ldots \ldots \ldots \ldots \ldots$

5-2 Summary of Input Data Sources for the Atlanta Episode $\ldots \ldots \ldots \ldots \ldots \ldots \ldots \ldots \ldots .2$

5-3 A Summary of Major Scurces and Sinks of the Toxic Chemicals in the Atlanta Modeling Domain for the Base Run for $30-31$ July $1987 \ldots \ldots \ldots \ldots \ldots \ldots \ldots \ldots \ldots$

5-4 A Summary of the Chenical Production of $\mathrm{O}_{3}$ and Other Chemicals over the Period 30-31 July 1987 in the Atlanta Modeling Domain . . . . . . . . . . . . 5-5

Urban Airshed Modeling of Air Quality Imps.cts of Alternative 


\section{LIST OF TABLES (Concluded)}

Page

6-1 Estimated Emissions in Los Angeles Modeling Domain for 2007 for SI Scenario and RFG and CNG Scenarios Incremental Emissions ...................... 6-2

6-2 RFG Scenario Selected Speciation of Gasoline Powered On-Road Motor

Vehicle Emissions for Los Angeles for 2007 Expressed as $\mathrm{CH}_{4}$

Equivalents . . . . . . . . . . . . . . . . .

6-3 Daily Maximum and Average $\mathrm{O}_{3}$ Concentrations in the Los Angeles

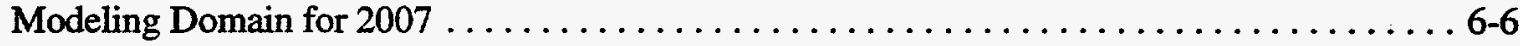

6-4 Daily Maximum and Average 8-Hour $\mathrm{O}_{3}$ Concentrations in the Los Angeles

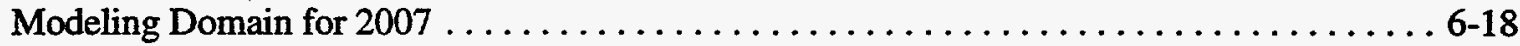

6-5 Population Exposure to Predicted Surface $\mathrm{O}_{3}$

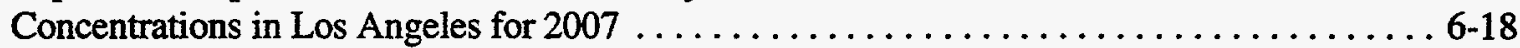

6-6 Daily Maximum 1-Hour Concentrations and Domain-Wide Cumulative

Population Exposures to Each of the Four Toxic Compounds in the

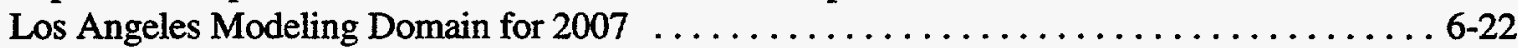

6-7 $\quad \mathrm{O}_{3}$ Sensitivities (ppb/ton) for Peak Maximum Daily $\mathrm{O}_{3}$ in

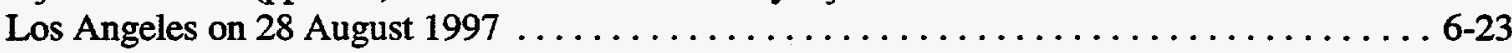

6-8 $\mathrm{O}_{3}$ Formation Potentials (ton- $\mathrm{O}_{3}$ /ton-emissions) over the Entire Modeling Domain

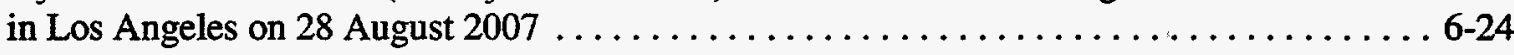

6-9 Reactivity-Weighted Daily VOC Emissions Increment for Alternative

Fuel Scenarios, Los Angeles, 2007

6-10 A Summary of Cumulative Domain-wide Mass Exchanges (Fluxes, Sources,

Sinks) for Selected Chemicals over the 2-Day Period 27-28 August 2007

7-1 Estimated Emissions in Atlanta Modeling Domain for 2007

Emissions Scenarios

7-2 Speciation of VC Emissions Increment for LRVP Gasoline

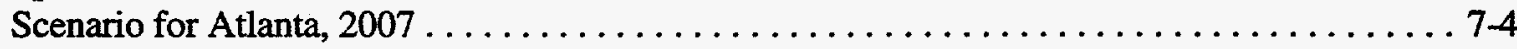

7-3 Daily Maximum and Average $\mathrm{Peak} \mathrm{O}_{3}$ Concentrations for 2007Atlanta

Emissions Scenarios . ...........................

7-4 Maximum and Domain-Wide Average Peak 8-hour Average

$\mathrm{O}_{3}$ Concentration in the Atlanta Modeling Domain ..................... $7-13$

7-5 Estimated Population Exposures to Predicted $\mathrm{O}_{3}$

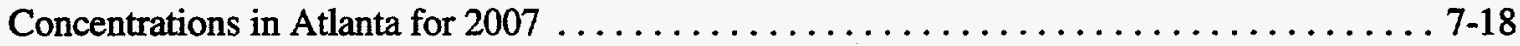

7-6 Daily Maximum 1-Hour Concentrations and Domain-Wide Cumulative

Population Exposures to Each of the Four Toxic Compounds in the Atlanta

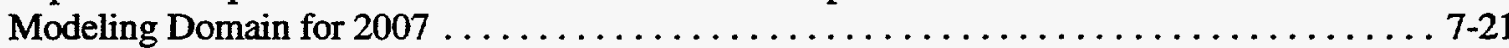

7-7 $\quad \mathrm{O}_{3}$ Sensitivities (ppb/ton) Based on Maximum 1-Hour

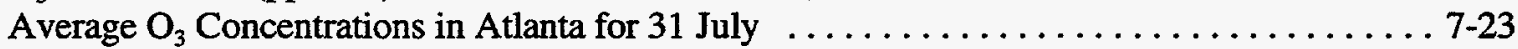

7-8 $\quad \mathrm{O}_{3}$ Formation Potentials (ton- $\mathrm{O}_{3}$ /ton-emissions) Over Atlanta Modeling

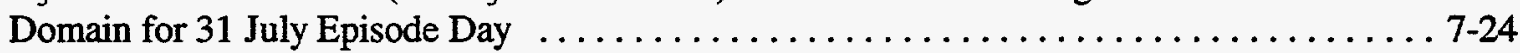

7-9 Summary of Actual and Reactivity-Weighted Daily VOC Emissions from

Alternatively Fueled vehicles by Species for 31 July 2007 in the Atlanta

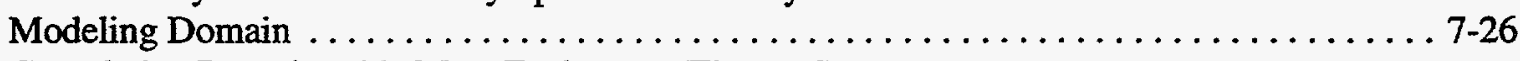

7-10 Cumulative Domain-wide Mass Exchanges (Fluxes, Sources,

Sinks) for Selected Chemical Species Over the 2-Day Period 30-31 July $2007 \ldots \ldots \ldots \ldots$ 7-27

Urban Airshed Modeling of Air Quality Impacts of Alternative

Transportation Fuel Use in Los Angeles and Atlanta 


\section{List of Acronyms}

ACRO Acrolein - CBM-IV species name for air toxics version

ACET Acetaldehyde - (.BM-IV species name for toxics version

AFV

Alternatively fueled vehicle or alternate fuel vehicle

ALD2 higher aldehydes - Original CBM-IV species name

AQMP Air Quality Management Plan

ARB California Air R zsources Board

BEIS Biogenic Emission Information System

BENZ Benzene - CBM-IV species name for air toxics version

BTU British thermal unit

BUDI 1,3-butadiene - CBM-IV species name for air toxics version

CBM-IV Carbon Bond Mechanism, Version IV, a chemical kinetics mechanism used in photochemical miodels

\section{$\mathrm{CH}_{4} \quad$ Methane}

CNG Compressed natural gas

$\mathrm{CO} \quad$ Carbon monoxide

$\mathrm{CO}_{2} \quad$ Carbon dioxide

DNR Georgia Department of Natural Resources

EMFAC7F Version for the rnotor vehicle emission factor model developed by the ARB

ETH Ethylene - CBM.IV species name

FORM Formaldehyde - CBM-IV species name

FTP Federal Test Procedure - the standard driving cycle

GEMAP Geocoded Emissions Modeling and Projection - an emission processing model used to develop model ready emissions files

GHG Greenhouse gases

HALD Higher aldehyde; - CBM-IV species name for air toxics version

$\mathrm{HNO}_{3} \quad$ Nitric acid

IOLE Internal olefins - CBM-IV species name for air toxics version

IR Incremental reactivity

LAX Los Angeles International Airport

LDT Light-duty truck

LDGV Light-duty gasoline vehicle

LDV Light-duty vehicle

LRVP Low Reid Vapor Pressure Gasoline

LST $\quad$ Local standard time

MDT Medium-duty tru.ck

MIR Maximum incrernental reactivity

MOBILE5a Latest version of the motor vehicle emission factor model developed by the U.S. EPA

MOR Maximum ozone reactivity

NO Nitric oxide

$\mathrm{NO}_{2} \quad$ Nitrogen dioxide

$\mathrm{NO}_{x} \quad$ Nitrogen oxides, composed of $\mathrm{NO}$ and $\mathrm{NO}_{2}$

$\mathrm{NO}_{\mathrm{y}} \quad$ Total nitrogen oxides

NREL National Renew:ble Energy Laboratory

$\mathrm{O}_{3} \quad$ Ozone 


\section{List of Acronyms (Continued)}

Off-FTP As used in this study, operation of a motor vehicle outside the speed and acceleration (load) boundaries of the FTP

OLE Olefins - CBM-IV species name

PAN Peroxyacetyl nitrate - CBM-IV species name

PAR Paraffin - CBM-IV species name

$\mathrm{ppb} \quad$ parts per billion - a unit of concentration

QA Quality assurance

RFG Reformulated gasoline

RVP Reid vapor pressure, a measure of gasoline volatility

SAI Systems Applications International

SCAQMD South Coast Air Quality Management District

SIP State Implementation Plan

TOG Total organic gas

TOL Toluene - CBM-IV species name

UAM Urban Airshed Model - A photochemical grid model

UAM-IV Version IV of the Urban Airshed Model

ULEV Ultra low emission vehicle

UNIX A computer operating system

U.S. DOE United States Department of Energy

U.S. EPA United States Environmental Protection Agency

UTM Universal Transverse Mercator map grid system

VMT Vehicle miles traveled

VOC Volatile organic compound

VOC:NO ${ }_{x}$ Ratio of volatile organic compound to nitrogen oxides

XYL Xylene - CBM-IV species name 


\section{Summary}

This report documents a photochemical modeling study of the potential impacts on air quality of future emissions from alternative fuel vehicles (AFVs). Although the emissions scenarios examined in this study are unlikely to occur in the time frame postulated, they provide a consistent basis on which to evaluate potential air quality impacts associated with future potential use of each fuel. This report is funded under subcontract YCC-05-14072-01 from the National Renewable Energy Laboratory (NREL).

\section{S.1 Project Overview}

The main objective of NREL in supporting this study is to determine the relative air quality impact of the use of compressed natural gas (CNG) as an alternative transportation fuel when compared to low Reid vapor pressure (RVP) gasoline and reformulated gasoline (RFG). Table S-1 lists the criteria, air toxic, and greenhouse gas pollutants for which emissions were estimated for the alternative fuel scenarios. Air quality impacts were then estimated by performing photochemical modeling of the alternative fuel scenarios using the Urban Airshed Model Version 6.21 and the Carbon Bond Mechanism Version IV (CBM-IV) (Geary et al., 1988). Using this model, we examined the formation and transport of ozone under alternative fuel strategies for motor vehicle transportation sources for the year 2007. Photochemical modeling was performed for modeling domains in Los Angeles, California, and Atlanta, Georgia.

Table S-1. Criteria, Toxic, and Greenhouse Gas Pollutants for Which Emission Estimates Were Developed for Alternative Fuel Vehicles

\begin{tabular}{ccc}
\hline Criteria & Toxicities & Greenhouse Gases \\
\hline Nitrogen oxides $\left(\mathrm{NO}_{\mathrm{x}}\right)$ & Benzene & Methane $\left(\mathrm{CH}_{4}\right)$ \\
Volatile organic compounds $(\mathrm{VOC})$ & 1,3 -Butadiene & Carbon dioxide $\left(\mathrm{CO}_{2}\right)$ \\
Carbon monoxide $(\mathrm{CO})$ & Formaldehyde & Nitrous oxide $\left(\mathrm{N}_{2} \mathrm{O}\right)$ \\
& Acetaldehyde & \\
\hline
\end{tabular}

A project team consisting of Radian Corporation, Earth Technology Corporation, and Mr. James Killus performed this study. Radian was responsible for overall management of the project, emissions estimation and modeling, and preparation of project reports. Earth Technology was responsible for photochemical modeling and analysis of air quality impacts. Mr. Killus modified the chemical mechanisms used in the photochemical modeling to handle explicitly the toxic compounds emitted from AFVs.

\section{S.2 Overview of Methodology}

Emissions estimates for the two future-year fuel scenarios, gasoline and CNG, for the two modeling domains, Los Angeles and Atlanta, were based on the most advanced vehicle technology currently available. Advanced CNG vehicles are dedicated to the use of CNG, but are not optimized for use of CNG. Emissions for the future year (2007) baseline scenario were calculated using emission factors for gasoline fueled vehicles from the current emission factor models, MOBILE5a (U.S. EPA 1993) and EMFAC7F (ARB 1994). The gasoline-based fuels are assumed to be California Phase 2 RFG for Los Angeles and conventional reduced Reid vapor pressure (RVP) gasoline for Atlanta. From this future-year 
baseline scenario, we developed the future-year CNG scenario which assumes $100 \%$ penetration of CNG into the light- and medium-duty' vehicle fleet.

After estimating future-year enission factors for vehicle fleets fueled with RFG (Los Angeles) and low RVP (LRVP) gasoline (Atlanta), we developed emission adjustment factors to account for potential average fleet operation outside the bounds of the Federal Test Procedure (FTP) and for the use of CNG as a motor vehicle fuel. For this study, off.FTP operation was defined as vehicle operation outside the speed and load (acceleration) boundaries encoinpassed by the FTP. Emission adjustment factors for off-FTP operation and for CNG fueled vehicles were developed by Radian from motor vehicle emission test data available from several recent research programs, such as Kelley and Grablicki (1993), and Marshal (1994).

The motor vehicle emissions inputs for UAM-IV for each modeling scenario were calculated using files of hourly, gridded traffic characteristics obtained from the South Coast Air Quality Management District (SCAQMD) and the Georgia Department of Natural Resources (DNR). Emission estimates of the air toxic compounds were obtained directly from the speciation of total organic gas (TOG) emissions into constituent compounds using the Geocoder Emissions Modeling and Projection (GEMAP) System which has been upgraded to the EMS-95 described by Emigh and Wilkinson (1995). For estimating $\mathrm{CO}_{2}$ emissions, we assumed all fuel carbon was combusted to $\mathrm{CO}_{2}$. For $\mathrm{CH}_{4}$ and $\mathrm{N}_{2} \mathrm{O}$ emissions, we used three methods to estimate emissions; direct speciation, and application of two alternative sets of emission factors.

To accomplish our modeling objectives, we obtained data files from UAM-IV regulatory ozone modeling episodes developed by SCAQMD and DNR. After evaluating the available episodes, we selected for modeling in this study the 27-28 August 1987 modeling episode for Los Angeles and the 29-31 July 1987 modeling episode for Atlanta. In our modeling, we used the agency methodology and modified model input files only where necessary to address the alternative fuel scenarios. Our goal in modeling was to duplicate the agency regulatory modeling methodology as closely as possible. As part of our analysis of model output, we examined pe:k 1-hour concentrations of ozone, VOC, $\mathrm{NO}_{\mathrm{x}}$, and air toxicities; 8-hour average ozone concentrations; population exposure to ozone and air toxicities; ozone formation potential of emissions; and reactivity-weighted emissions.

Animation files that include side-by-side comparisons of the emissions and photochemical modeling results are provided as part of the final report. We prepared animations of hourly ozone isopleths and VOC and $\mathrm{NO}_{\mathrm{x}}$ emissions tile plots. Indivirlual animations of emissions and ozone concentrations were prepared for both cities for the gasoline and CNG scenarios for 2007. These animations are in a file format suitable for linking to a Web page or viewing with public domain animation software.

\section{S.3 Motor Vehicle Emissions Analysis Results}

The available data on motor vehicle emissions reflect both current technology and technology that is expected in the near future. NREL supplied to Radian a database of all motor vehicle emissions test data for alternative fuels and RFG available at NREL at the time of the study. These include exhaust and evaporative emissions data for advanced technology CNG vehicles, as well as data for California RFG vehicles. We also performed a literature search and updated the NREL-supplied data with data from other sources. Of these data, only emissions data that reflect vehicles optimized for RFG or gasoline or dedicated for CNG were used in this study.

After assembling these data, we developed adjustment factors representing the ratio of fleet-average CNG emission factors to low RVP gesoline or RFG emission factors to reflect the use of CNG as the vehicle fuel. In addition, we developed. speciation profiles for CNG vehicle exhaust and evaporative emissions. 
Our estimates of future-year emissions account for future emission standards and the impact of expected control technology. The emissions adjustment factors account for emissions from vehicles operating under both FTP and off-FTP conditions of speed and load.

Emission adjustment factors were developed from these data for light- and medium-duty gasoline vehicles. The adjustment factors are multiplicative factors that are applied to the MOBILE5a and EMFAC7F emission factors to yield emission factors for CNG-powered vehicles, and to reflect the effects of off-FTP operation. The emission factor models themselves were not modified. The adjustment factors are "fleetaverage" values (averaged over vehicle age and operating cycle) by vehicle type (light-duty vehicle, lightduty truck, etc.) and by operating mode (cold start, hot start, etc.). Adjustment factors are applied by vehicle type and emission mode, without regard for variations in other environmental or operating characteristics, such as ambient temperature or speed distribution. Three sets of adjustment factors were developed and applied for this study: off-FTP adjustment factors for gasoline-fueled vehicles (one set of factors applicable to both Atlanta and Los Angeles); gasoline-to-CNG adjustment factors (including off-FTP effects) for Atlanta; and RFG-to-CNG adjustment factors for Los Angeles. Differences in the chemical speciation of the total organic gas (TOG) emissions resulting from CNG rather than gasoline usage were accounted for.

Table S-2 represents our best estimates of composite fleet-average RFG, low RVP gasoline, and CNG emissions factors for 2007 for Los Angeles and Atlanta assuming operation within the bounds of the FTP test procedure. Tables S-3 and S-4 present the adjustment factors applied to estimate exhaust emissions for 2007 for Atlanta and Los Angeles, respectively, that account for the effects of fuel and off-FTP operation by vehicle type and emission mode.

Table S-2. Estimated Light- and Medium-Duty Fleet Composite Average Exhaust Emission Factors for FTP Operation for Year 2007, Average Summer Day (units are grams/mile)

\begin{tabular}{lccc}
\hline Pollutant & $\begin{array}{c}\text { Los Angeles } \\
\text { RFG Baseline }\end{array}$ & $\begin{array}{c}\text { Atlanta } \\
\text { Low RVP Gasoline } \\
\text { Baseline }\end{array}$ & CNG \\
\hline TOG & 0.27 & 0.85 & 0.55 \\
NO & 0.53 & 1.1 & 0.20 \\
CO & 3.8 & 11.0 & 1.9 \\
\hline
\end{tabular}


Table S-3. Exhaust Ernission Adjustment Factors for Atlanta for Year 2007 (off-FTP)

\begin{tabular}{llcl}
\hline Pollutant & $\begin{array}{l}\text { Vehicle } \\
\text { Type }\end{array}$ & $\begin{array}{l}\text { Low RVP } \\
\text { Gasoline }^{\text {b }}\end{array}$ & CNG $^{\text {b }}$ \\
\hline TOG & LDGV & 1.3 & 0.75 \\
& LDGT1 & 1.2 & 0.69 \\
& LDGT2 & 1.3 & 0.62 \\
$\mathrm{NO}_{\mathrm{x}}$ & LDGV & 2.0 & 0.29 \\
& LDGT1 & 1.8 & 0.27 \\
& LDGT2 & 1.6 & 0.30 \\
CO & LDGV & 2.7 & 0.34 \\
& LDGT1 & 2.2 & 0.32 \\
& LDGT2 & 2.4 & 0.59 \\
\hline
\end{tabular}

a Note: LDGV = Light-duty gasoline vehicles

LDGT1 $=$ Light-duty ga soline trucks ( $0-6,000$ pounds gross vehicle weight (GWW)

LDGT2 $=$ Light-duty gesoline trucks $(6,000-8,500$ pounds $G W M)$

- To obtain the adjusted exhaust emissions including off-FTP impacts for a given fuel, the baseline emissions estimated using the MOBILE5a emission model are multiplied by the appropriate adjustment factor.

The motor vehicle emissions estimates developed in this study are subject to significant limitations and uncertainties, beyond those assuciated with emission estimates for conventional gasoline-fueled vehicles. Available test data used to chajacterize emissions from CNG-fueled vehicles or from off-FTP operation of gasoline-fueled vehicles is quite limited. From the available data, it is not feasible to develop emission factors or adjustment factors thit accurately reflect variations in emissions by vehicle type and operating mode. The emissions estimation procedures employed for this study are intended only to characterize the relative quantities of composite, fleet-average emissions for different fuel scenarios. 
Table S-4. Exhaust Emission Adjustment Factors for Los Angeles for Year 2007 (off-FTP)

\begin{tabular}{|c|c|c|c|c|}
\hline Pollutant & Operating Mode & Vehicle Type $^{a}$ & $\mathrm{RFG}^{\mathrm{b}}$ & $\mathrm{CNG}^{\mathrm{t}}$ \\
\hline \multirow[t]{9}{*}{ TOG } & Cold Start & LDV & 1.3 & 1.0 \\
\hline & & LDT & 1.2 & 1.0 \\
\hline & & MDT & 1.3 & 1.0 \\
\hline & Hot Start & LDV & 1.3 & 4.3 \\
\hline & & LDT & 1.2 & 4.3 \\
\hline & & MDT & 1.3 & 4.3 \\
\hline & Hot Stabilized & LDV & 1.3 & 2.8 \\
\hline & & LDT & 1.2 & 2.8 \\
\hline & & MDT & 1.3 & 2.8 \\
\hline \multirow[t]{9}{*}{$\mathrm{NO}_{x}$} & Cold Start & LDV & 2.0 & 1.1 \\
\hline & & LDT & 1.8 & 1.1 \\
\hline & & MDT & 1.6 & 1.1 \\
\hline & Hot Start & LDV & 2.0 & 0.57 \\
\hline & & LDT & 1.8 & 0.57 \\
\hline & & MDT & 1.6 & 0.57 \\
\hline & Hot Stabilized & LDV & 2.0 & 0.40 \\
\hline & & LDT & 1.8 & 0.40 \\
\hline & & MDT & 1.6 & 0.40 \\
\hline \multirow[t]{9}{*}{ Co } & Cold Start & LDV & 2.7 & 1.2 \\
\hline & & LDT & 2.2 & 1.2 \\
\hline & & MDT & 2.4 & 1.2 \\
\hline & Hot Start & LDV & 2.7 & 2.3 \\
\hline & & LDT & 2.2 & 2.3 \\
\hline & & MDT & 2.4 & 2.3 \\
\hline & Hot Stabilized & LDV & 2.7 & 0.82 \\
\hline & & LDT & 2.2 & 0.82 \\
\hline & & MDT & 2.4 & 0.82 \\
\hline
\end{tabular}

Note: LDV = Light-duty vehicles

LDT = Light-duty trucks

MDT = Medium-duty trucks

- To obtain the adjusted exhaust emissions including off-FTP impacts for a given fuel, the baseline emissions estimated using the EMFAC7F emission model are multiplied by the appropriate adjustment factor.

Estimates of greenhouse gas emissions for 2007 for the gasoline/RFG and CNG scenarios are given in Table S-5. For both areas, the $\mathrm{CO}_{2}$ emissions for the gasoline scenarios are larger than those for CNG, while $\mathrm{CH}_{4}$ emissions are smaller. All carbon in the fuels was assumed to be combusted to $\mathrm{CO}_{2}$. No $\mathrm{N}_{2} \mathrm{O}$ is estimated to be emitted from CNG vehicles, while small amounts are emitted from gasoline-fueled vehicles. 
Table Si-5. Greenhouse Gas Emissions from Light- and Medium-Duty Vehicles for Alternative Fuel Scenarios for 2007 [tons/day]

\begin{tabular}{ccccc}
\hline Area & Modeling Scenario & $\mathrm{CO}_{2}$ & $\mathrm{CH}_{4}$ & $\mathrm{~N}_{2} \mathrm{O}$ \\
\hline Los Angeles & RFG & 160,000 & 30 & 8 \\
& CNG & 120,000 & 200 & 0 \\
\multirow{2}{*}{ Atlanta } & Low R'/P Gasoline & 67,000 & 25 & 15 \\
& CNG & 50,000 & 140 & 0 \\
\hline
\end{tabular}

Note: All emission estimates are rounded to two or fewer significant figures.

Estimates of air toxic emissions for the two areas and fuel scenarios are given in Table S-6. For each city, the CNG scenario produces lowrer emissions of all four air toxicities compounds.

Table S-6. Air Toxic Emissions from Light- and Medium-Duty Vehicles for Alternative Fuel Scenarios for $\mathbf{2 0 0 7}$ (tons/day)

\begin{tabular}{|c|c|c|c|c|c|}
\hline Area & $\begin{array}{c}\text { Fuel } \\
\text { Scenario } \\
\end{array}$ & Benzene & 1, 3-Butadiene & Acetaldehyde & Formaldehyde \\
\hline \multirow{2}{*}{$\begin{array}{c}\text { Los } \\
\text { Angeles }\end{array}$} & RFG & 5.7 & 0.28 & 0.25 & 0.80 \\
\hline & CNG & 0.03 & 0.02 & 0.02 & 0.15 \\
\hline \multirow[t]{2}{*}{ Atlanta } & $\begin{array}{l}\text { Low RVP } \\
\text { Gasoline }\end{array}$ & 8.2 & 0.88 & 0.88 & 1.9 \\
\hline & CNG & 0.02 & 0.01 & 0.01 & 0.11 \\
\hline
\end{tabular}

Note: All emission estimates are rounded to two or fewer significant figures.

\section{S.4 Development of Toxics CBM-IV Chemical Mechanism}

The identification of acetaldehy'de as a toxic chemical of concern in this project required that the higher aldehyde chemical lumping of the present version of the CBM-IV mechanism be revised to break out acetaldehyde as a separate chemical species. This disaggregation requires significant changes in the CBM-IV mechanism used in UAM-IV version 6.21. Other changes were required to account for the gas phase chemistry of the toxic species benzene and 1, 3-Butadiene.

The highly aggregated version of the Carbon Bond chemical reaction mechanism known as CBM-IV has 10 primary organic species. Three of these species are highly lumped surrogates: paraffins (PAR), olefins 
(OLE), and higher aldehydes (ALD2). The complete chemical mechanism has 23 species total and is represented by 86 chemical reactions. In the toxicities enhancement to the CBM-IV mechanism, 23 new reactions have been added. Most significantly, the "higher aldehydes" surrogate (ALD2) has been separated into three species: acetaldehyde (ACET); internal olefins, including cis- and trans- 2 butene (IOLE); and the remaining higher aldehydes (HALD).

The toxic species benzene and 1, 3-Butadiene, plus acrolein (a species whose chemistry is linked to 1, 3Butadiene) were installed as "ghost" state variables, with no feedback to ozone photochemistry. Thus, the emission and decay of those three compounds can be described explicitly, whereas their role in ozone photochemistry is treated within the existing Carbon Bond structural classes already in the model.

The results of testing the toxicities version of the CBM-IV chemical mechanism indicate that:

- Between $5 \%$ and $10 \%$ less ozone is formed using the toxic CBM-IV mechanism. The modifications lead to reductions in photolysis, changes in radical production resulting from the altered breakdown pathway for aldehydes, and changes in the efficiency of $\mathrm{NO}$ to $\mathrm{NO}_{2}$ conversion by radicals.

- Benzene decays very slowly, so that most emitted benzene is likely to be exported out of the modeling domain. 1, 3-Butadiene reacts very rapidly; significant concentrations of 1, 3-Butadiene are likely to exist only near large source regions.

- The changes in the model chemistry did not make any significant change in either the predicted ambient $\mathrm{NO}_{\mathrm{x}}$ concentrations or VOC concentrations.

\section{S.5 Results of Photochemical Modeling}

Three modeling emission scenarios were developed for Los Angeles and Atlanta for the future year (2007). The S1 scenario consists of emissions from all sources in the future-year emission inventory except lightand medium-duty gasoline or CNG-fueled vehicles and the fuel marketing and distribution sources supporting these vehicles. This scenario represents the "maximum" emission reduction scenario whereby all light and medium duty gasoline or CNG on-road vehicle emissions are eliminated. This scenario represents the unaffected sources whose emissions remain the same, regardless of motor vehicle fuel option.

The gasoline-fueled scenario contains emissions from all light- and medium-duty on-road gasoline vehicles and their associated fuel marketing and distribution emissions, assuming operation on RFG (Los Angeles) or low RVP gasoline (Atlanta), together with the S1 scenario emissions. Likewise, the CNG emissions scenario consisted of all light- and medium-duty vehicles operating on CNG, plus the S1 emissions.

The UAM-IV model output for the three scenarios for the two cities was examined using the following metrics: peak 1-hour and 8-hour surface ozone concentration, cumulative ozone and air toxicities exposures, and sensitivity of predicted ozone production to reactivity-weighted incremental emissions.

For peak 1-hour and 8-hour ozone concentrations, the following results were obtained:

- In Los Angeles, domain-wide emissions of VOC and $\mathrm{NO}_{\mathrm{x}}$ were largest for the gasoline-fueled (RFG) scenario. The RFG scenario produced the highest predicted peak 1-hour ozone 
concentrations, while the S1 scenario predicted the lowest. This result was true for both days of the two-day simulation

- For Atlanta, domain-vride $\mathrm{NO}_{\mathrm{x}}$ and VOC emissions were highest for the low RVP gasoline scenario. For July 30 , the highest peak 1-hour ozone concentration (172 ppb) was predicted for the low RVP gasoline scenario. For July 31, the highest 1-hour ozone concentration (again 172 $\mathrm{ppb}$ ) was predicted for the $\mathrm{S} 1$ scenario.

- For both modeling domains, the spatial pattern of predicted peak 1-hour ozone concentrations for the CNG scenario closely resembles that of the S1 scenario.

- The results for the peak 8-hour average ozone concentrations generally parallel the results for the peak 1-hour ozone concentrations for both cities. For Atlanta, the maximum predicted 8-hour average ozone concentration is $83 \%$ of the maximum 1-hour prediction. For Los Angeles, by contrast, the maximum 8 -hour prediction is $75 \%$ of the naximum 1 -hour prediction.

For cumulative population expcsure to ozone and toxic compounds, the following results were obtained:

- In Atlanta and Los Angiles, the cumulative exposure to ozone decreased from the S1 scenario for both the gasoline-fueled and CNG scenarios. In Los Angeles, the lowest exposures were predicted for the RFG scenario. The reduction in exposure from the no-vehicle case appears to be due to an increase in titration of ozone by NO emissions from motor vehicles during the course of the entire day, including nighttime hours.

- In Atlanta, the cumulative ozone exposure for the low RVP gasoline scenario is larger than that for the CNG scenario on the first day but is smaller on the second day. This shift in exposure pattern suggests that, mitteorology can have a significant influence on estimated ozone exposures.

- The gasoline-fueled scenarios produce the highest emissions and the largest exposures to toxic compounds for both cities.

In terms of reactivity, the following results were obtained:

- Total $\mathrm{NO}_{\mathrm{x}}$ and VOC emnissions from the gasoline-fueled scenarios are larger than those for the CNG scenario. However, when the mass of ozone formed is normalized by the VOC mass of emissions it was found that less ozone was formed per ton for gasoline fueled vehicles than from the CNG scenario.

- For Atlanta, the net ozone formation was smaller for the low RVP gasoline scenario than the S1 scenario where there were no on-road light duty vehicle emissions.

- The ozone formation potential for only aromatic species were found to be consistently negative. Since the gasoline fueled scenarios have larger mass fractions of aromatics than CNG vehicles, the smaller ozone formation per ton of emission of gasoline fueled vehicles is likely due to the aromatic compounds. 


\section{S.6 Conclusions}

The principal conclusions from our work are:

1. With the exception of the greenhouse gas methane, CNG fueled vehicles emit less pollutants than gasoline fueled vehicles. CNG vehicles have much lower emission rates of toxic air pollutants, and except for methane, lower emission rates for greenhouse gases. Emission rates for $\mathrm{VOC}, \mathrm{NO}_{\mathrm{x}}$ and $\mathrm{CO}$ are also lower for $\mathrm{CNG}$ fueled vehicles.

2. Emissions from RFG and low RVP gasoline fueled vehicles are predicted to promote more incremental ozone formation in the future year (2007) than are emissions from CNG fueled vehicles. The spatial patterns of ozone impacts from the CNG scenarios modeled are closer in appearance to those from scenarios where all light- and medium-duty vehicle emissions have been removed.

3. Cumulative population exposure to toxic air compounds is lower for the CNG scenarios than for the gasoline-fueled scenarios.

4. The modeling results for ozone present a complex picture of the competing processes that contribute to photochemical ozone formation. At night and in the immediate vicinity of $\mathrm{NO}_{x}$ emission sources, ozone titration by NO will reduce predicted ozone concentrations. Farther downwind, the same $\mathrm{NO}_{x}$ emissions can contribute to net ozone formation. Changes in predicted peak ozone concentrations and in ozone exposures, particularly near urban centers, are imperfect metrics for evaluating the impacts of alternative fuel scenarios. As a consequence, a scenario which produces higher emissions of ozone precursors may lead to lower predicted peak ozone concentrations and ozone exposures for a given city on a given episode day. The results for Atlanta illustrate such counter-intuitive behavior.

5. The directional impacts of alternative motor vehicle fuel strategies on emissions are well understood for most of the pollutants addressed in this study. Important limitations, however, are associated with both the motor vehicle emission factors and the photochemical modeling tools used to quantify emissions and air quality impacts. Further efforts to reduce the uncertainty associated with motor vehicle emission factors and to characterize episode-specific photochemical model performance are needed for a full evaluation of alternative motor vehicle fuel strategies.

6. There is a large amount of uncertainty in the emissions estimates for some greenhouse gases from motor vehicles and in the effects of off-FTP operation on motor vehicle emissions. Consequently, results presented in this study for greenhouse gases and off-FTP effects should be carefully evaluated for usefulness until they are verified in other studies. 


\subsection{Introduction}

This report documents the photochemical modeling study of the potential impacts on air quality of future emissions from alternative fuel vehicles (AFVs). Although the emissions scenarios examined in this study are unlikely to occur in the timeframe postulated, they provide a consistent basis on which to evaluate potential air quality impacts associated with future potential use of each fuel. This report is funded under subcontract YCC-05-14072-01 from the National Renewable Energy Laboratory (NREL).

\subsection{Project Overview}

The main objective of NREL in supporting this study is to determine the relative air quality impact of the use of compressed natural gas (CNG) as an alternative transportation fuel when compared to low Reid vapor pressure (RVP) gasoline and reformulated gasoline (RFG). Table 1-1 lists the criteria, air toxic, and greenhouse gas pollutants for which emissions were estimated for the alternative fuel scenarios. Air quality impacts were then estimated by performing photochemical modeling of the alternative fuel scenarios using the Urban Airshed Model Version 6.21 with the Carbon Bond Mechanism Version IV (CBIV) (Morris and Myers, 1990). Using this model, we examined the formation and transport of ozone under alternative fuel strategies for motor vehicle transportation sources for the year 2007. Photochemical modeling was performed for modeling domains in Los Angeles, California, and Atlanta, Georgia.

\section{Table 1-1. Criteria, Toxic, and Greenhouse Gas Pollutants for Which Emission Estimates Were Developed for Alternative Fuel Vehicles}

\begin{tabular}{ccc}
\hline Criteria & Toxics & Greenhouse Gases \\
\hline Nitrogen oxides $\left(\mathrm{NO}_{x}\right)$ & Benzene & Methane $\left(\mathrm{CH}_{4}\right)$ \\
Volatile organic compounds $(\mathrm{VOC})$ & 1,3 -Butadiene & Carbon dioxide $\left(\mathrm{CO}_{2}\right)$ \\
Carbon monoxide $(\mathrm{CO})$ & Formaldehyde & Nitrous oxide $\left(\mathrm{N}_{2} \mathrm{O}\right)$ \\
& Acetaldehyde & \\
\hline
\end{tabular}

A project team consisting of Radian Corporation, Earth Technology Corporation, and Mr. James Killus performed this study. Radian was responsible for overall management of the project, emissions estimation and modeling, and preparation of project reports. Earth Technology was responsible for photochemical modeling and analysis of air quality impacts. Mr. Killus modified the chemical mechanisms used in the photochemical modeling to handle explicitly the toxic compounds emitted from AFVs.

\subsection{Overview of Methodology}

Emissions estimates for the two future-year fuel scenarios, gasoline and CNG, for the two modeling domains, Los Angeles and Atlanta, were based on the most advanced vehicle technology currently available. Advanced CNG vehicles are dedicated to the use of CNG, but are not optimized for use of CNG. Emissions for the future year (2007) baseline scenario were calculated using emission factors for gasoline fueled vehicles from the current emission factor models, MOBILE5a (U.S. EPA 1993) and EMFAC7F (ARB 1994). The gasoline-based fuels are assumed to be California Phase 2 RFG for Los Angeles and conventional reduced Reid vapor pressure (RVP) gasoline for Atlanta. From this future-year 
baseline scenario, we developed the future-year CNG scenario which assumes $100 \%$ penetration of CNG into the light- and medium-dut $y$ vehicle fleet.

After estimating future-year er.1ission factors for vehicle fleets fueled with RFG (Los Angeles) and low RVP (LRVP) gasoline (Atlanta), we developed emission adjustment factors to account for potential average fleet operation outside the bounds of the Federal Test Procedure (FTP) and for the use of CNG as a motor vehicle fuel. For this study, off-FTP operation was defined as vehicle operation outside the speed and load (acceleration) boundaries encompassed by the FTP. Emission adjustment factors for off-FTP operation and for CNG fueled vehicles w'ere developed by Radian from motor vehicle emission test data available from several recent research programs.

The motor vehicle emissions irputs for UAM-IV for each modeling scenario were calculated using files of hourly, gridded traffic data oltained from the South Coast Air Quality Management District (SCAQMD) and the Georgia Department of Natural Resources (DNR). Emission estimates of the air toxic compounds were obtained directly from the speciation of total organic gas (TOG) emissions into constituent compounds using the Geocoded Emissiors Modeling and Projections System (GEMAP). For estimating $\mathrm{CO}_{2}$ emissions, we assumed all fuel carbon was combusted to $\mathrm{CO}_{2}$. For $\mathrm{CH}_{4}$ and $\mathrm{N}_{2} \mathrm{O}$ emissions, we used three methods to estimate emissions; direct speciation, and application of two alternative sets of emission factors. Details of the emissions modeling analysis and the estimation of the greenhouse gas and air toxics emissions AFVs are given in Appendix C.

\subsection{Overview of Photochemical Modeling Methodology}

Over the past five years considerable effort has been devoted to the study of potential air quality impacts of new fuels to be used in automobiles and trucks in the United States (Chang and Rudy 1990), (Pollack et al. 1992), (Russell et al. 1991). This research has been stimulated by provisions of the 1990 Clean Air Act Amendments (CAAA) that set key performance targets for alternative fuels. Major targets are: (1) an eventual $25 \%$ reduction of volatile organic compounds (VOCs) and toxics emissions, and (2) no increases in $\mathrm{NO}_{x}$ emissions (Reichhardt 1995). Because of the targets, major air quality considerations have been focused on the implacts of (1) alternative fuel emissions on $\mathrm{O}_{3}$ formation, and (2) human exposure to toxic compounds.

Comparing the effects of alternative fuels on air quality poses a number of challenges. Many fuels under consideration have potentially conflicting benefits and drawbacks with regard to estimated impacts on human health. For example, a fuel that offers benefits by reducing unhealthy $\mathrm{O}_{3}$ exposures in heavily populated regions may have the drawback of additional toxic air exposures. Such air quality issues are the major focus of the present study, in which the air quality impacts of AFVs are compared to the impacts of vehicles fueled by low RVP gasoline or RFG.

To accomplish our modeling objectives, we obtained and evaluated UAM-IV regulatory modeling episodes from two urban areas: applications by the SCAQMD for Los Angeles and by the Georgia DNR for Atlanta. After evaluating available episodes, we selected the 27-28 August 1987 modeling episode for Los Angeles and the 29-31 July 1987 modeling episode for Atlanta. Episode selection and modeling procedures are described in the Modeling Protocol (Appendix B). In our modeling, we used the agency methodology and model input files as received for each episode, except for the following changes:

- Modification of temperature gradients for the Los Angeles episode, after consultation with SCAQMD modeling staff, to correct erroneous values in the original input files 
Adjustment of initial and boundary conditions to allow inclusion of four toxic air pollutants into the modeling episode

Creation of new emission inventories to reflect the two alternative motor vehicle fuel scenarios for the year 2007 for each city.

Our goal in modeling was to build on the agency regulatory modeling analyses as closely as possible. Various model quality assurance (QA) and sensitivity simulations were carried out for each modeling domain to ensure the correct implementation of the episodes on our computer system. After confirming correct implementation of each episode, we performed a number of simulations to analyze the potential future impact of the two fuel scenarios. As part of our analysis of model output, we examined peak 1-hour concentrations of $\mathrm{O}_{3}, \mathrm{VOC}, \mathrm{NO}_{x}$, and air toxics; 8-hour $\mathrm{O}_{3}$ concentrations; population exposure to $\mathrm{O}_{3}$ and air toxics; $\mathrm{O}_{3}$ formation potential of emissions; and reactivity-weighted emissions.

In lieu of extensive sets of plots in an appendix presenting hourly isopleths for $\mathrm{O}_{3}$ and tile plots of VOC and $\mathrm{NO}_{\mathrm{x}}$ emissions, we provide as part of the final report animation files that include side-by-side comparisons of the emissions and photochemical modeling results. We prepared animations of hourly $\mathrm{O}_{3}$ isopleths and VOC and $\mathrm{NO}_{\mathrm{x}}$ emissions tile plots. Individual animations were prepared for each city for the following scenarios: base year with air toxics, base year with air toxics and no motor vehicle emissions, RFG scenario, and CNG scenario. These animations are in a file format suitable for linking to a Web page or viewing with public domain animation software.

\subsection{Organization of this Report}

The report is divided into eight sections (including this introductory section) and four appendices. In Section 2.0 , we present a summary of the emissions analysis of motor vehicle emissions that forms the basis of the alternative fuel strategies we analyze in this report. Details of the motor vehicle emissions analysis is given in Appendix $\mathrm{A}$.

Section 3.0 discusses the modifications made to UAM-IV photochemical model and the Carbon Bond IV chemical reaction mechanism (CBM-IV) to account for the photochemistry of four air toxic compounds: formaldehyde (FORM), acetaldehyde (ALD2), benzene (BENZ), and 1,3-butadiene (BUDI). The CBM-IV mechanism was altered to allow assessment of the impacts of these four air toxic compounds. This section describes the model implementation of the revised chemical schemes for toxics as well as changes made to model input preprocessors.

Sections 4.0 and 5.0, respectively, provide documentation of the setup and QA performed to verify proper functioning of the Los Angeles and Atlanta photochemical modeling episodes obtained from the respective regulatory agencies and used in this analysis. Sections 6.0 and 7.0 present the results of the photochemical modeling performed for the two cities using the motor vehicle emissions for the alternative fuel scenarios documented in Section 2.0. Finally, references are presented in Section 8.0.

Four appendices are a part of this report. Appendix A provides the documentation for the motor vehicle emissions analysis performed to estimate future year emissions from AFVs. Appendix B is the photochemical modeling protocol. Appendix $\mathrm{C}$ documents the emissions modeling performed to estimate the emissions of GHG and air toxics and to produce the photochemical model input files. Appendix D is an "electronic appendix" consisting of animated tile plots of the hourly emissions and predicted surfacelevel concentrations for each scenario, provided on a set of computer diskettes. These animations are designed for viewing using a public domain software program. 


\subsection{Motor Vehicle Emissions Analysis}

The primary objective of the emissions analysis task is to devise a methodology for estimating emissions from alternative fuel vehicles, suitable for generating the emission inputs required by UAM-IV. The goal is to produce emission estimates for a motor vehicle fleet fueled by CNG, building on the regulatory modeling framework. In addition to estimating criteria pollutant emissions, the methodology must provide estimates of greenhouse gas and air toxics emissions from both conventional and alternative fuel vehicles. The procedures and emission factors used to estimate motor vehicle emissions for this study are described below. Details of the motor vehicle emissions analysis for criteria pollutants are given in Appendix A. Details of the CNG and air toxics emissions analysis are given in Appendix C.

\subsection{Future Year Motor Vehicle Scenario Definition}

The future year 2007 RFG and CNG scenarios were based upon full penetration of the most advanced vehicle technology currently available. We assumed that all CNG vehicles were dedicated to the use of CNG but were not optimized for use of CNG. We developed as part of this study comparable emission factor estimates for gasoline and CNG fueled vehicles. Emissions for the 2007 gasoline fuel scenarios were produced with the current emission factor models, MOBILE5a (U.S. EPA 1993a) and EMFAC7F (ARB 1994). The gasoline-based fuels were assumed to be California Phase 2 RFG for Los Angeles and LRVP gasoline for Atlanta. From the future year gasoline scenarios, we then developed the future year CNG scenario, which assumed $100 \%$ penetration of CNG into the light- and medium-duty vehicle fleet. As part of the regulatory modeling process, estimates of projected future motor vehicle activity had been produced for each urban area. Foundation files of hourly traffic characteristics for 2007, allocated to individual modeling grid cells, were obtained from SCAQMD and Georgia DNR. The motor vehicle emission estimates for all scenarios were developed using these foundation files.

Specific assumptions inherent in the alternative fuel scenarios were:

- $100 \%$ conversion of all on-road light- and medium-duty gasoline-powered vehicles to CNG.

- $100 \%$ conversion of light- and medium-duty motor vehicle fuel marketing and transportation sources to reflect use of $\mathrm{CNG}$ in place of current gasoline fuels.

- On-road emission estimates include estimates of incremental emissions due to on- and off-FTP operation. The FTP is the Federal Test Procedure. Off-FTP refers to operation outside the load and speed boundaries of the FTP.

- $\quad$ LRVP and RFG vehicle fleets reflect optimized vehicles that employ the most sophisticated technology for which emissions data are currently available.

- CNG vehicle fleets reflect dedicated, but not optimized, vehicles that employ the most sophisticated technology for which emissions data are currently available.

- $\quad$ RFG and LRVP emission factors and deterioration rate distributions reflect the assumptions and methodology in the EMFAC7F and MOBILE5a models, respectively.

- Current CNG ULEV emissions are representative of 2007 CNG ULEVs. 
Future year 2007 emiss ion factors and deterioration rate distributions of the CNG fleet is based on the RFG and LRVP deterioration rate distributions.

\subsection{Overview of Motor '/ehicle Emissions Analysis Methodology}

The emission factor models which are used to estimate motor vehicle emissions of criteria pollutants for regulatory applications are desijned to characterize fleet-average emissions as a function of operating and environmental conditions. Models such as MOBILE5a and EMFAC7F have been developed using emissions test data from both prototype and in-use (gasoline-fueled) motor vehicles collected over a wide range of operating cycles and e:zvironmental conditions. For CNG fuel vehicles, by contrast, only a very limited amount of emissions tes: data is available, based on a small set of prototype vehicles and a limited range of operating conditions.

The emissions estimation approach which was devised for this study was designed to build on the existing framework of emission models for gasoline fuel motor vehicles. Using available test data for CNG fuel vehicles, a set of "adjustment factors" were developed that reflect the ratio between motor vehicle emissions fueled with CNG versus gasoline. These pollutant-specific adjustment factors were then applied to the hourly, gridded emission estimates for gasoline fuel vehicles, in order to calculate emissions for the CNG scenario. To obtain appropriate emission estimates for the CNG fuel scenarios in Los Angeles and Atlanta, it was necessary to develop two different sets of adjustment factors. The EMFAC7F emission factors for gasoline fuel vehicles for Los Angeles for 2007 reflect RFG and California emission control requirements, while the MOBILE5a emissior. factors used for Atlanta reflect conventional LRVP gasoline and federal control requirements.

Emissions of air toxics compounds for each fuel scenario were calculated by applying speciation profiles to the TOG emissions estimate:s. Different profiles were applied for evaporative and exhaust emissions, and for gasoline versus CNG tuel. For greenhouse gases, emission calculations were not used for air quality modeling, but are only intended to compare domain-wide emissions for different fuel scenarios. Alternative estimates for gres:nhouse gases from motor vehicles were developed based on energy consumption, speciation profiles, and direct emission factors.

The available data on motor vehicle emissions reflect both current technology and technology that is expected in the near future. The NREL supplied to Radian a database of all the motor vehicle emissions test data for alternative fuels and RFG available at NREL at the time of the study. These data include exhaust and evaporative emissions data for advanced technology CNG vehicles, as well as data for California RFG vehicles. We also performed a literature search and updated the NREL-supplied data with data from other sources. Of these data, only emissions data that reflect vehicles optimized for RFG or gasoline or dedicated for CNG were used in this study.

After assembling these data, we developed adjustment factors consisting of the ratio of fleet-average CNG emission factors to LRVP gasoline or RFG emission factors to reflect the use of CNG as the vehicle fuel. In addition, we developed estinnates of the speciation of the vehicle exhaust and evaporative emissions. Our estimates of future year enissions account for future emission standards and the impact of expected control technology. The emissions adjustment factors account for emissions from vehicles operating under both FTP and off-FTP conditions of speed and load.

Off-FTP emissions from gasoline powered vehicles depart most from those expected under the FTP driving cycle during conditions of fuel enrichment under full power operation (hard accelerations and high speeds). Unlike gasoline powered vehicles, CNG fuel vehicles can operate at near-stoichiometric conditions under 
full power. Therefore, CNG fueled vehicles may not experience increases in emissions from off-FTP operation comparable to those observed for gasoline powered vehicles.

We produced one set each of FTP and off-FTP operation adjustment factors for each fuel. Emissions data for CNG fueled vehicles are limited at this time. Therefore, our approach for CNG was to use our experience and engineering judgement to extrapolate available CNG emissions data to produce a consistent set of emission factors for FTP and off-FTP operation by vehicle type and operating mode.

Emission adjustment factors were developed for light-duty and medium-duty gasoline vehicles. The adjustment factors are a multiplicative factor that are applied to the MOBILE5a and EMFAC7F emission factors to yield emission factors for CNG powered vehicles, including off-FTP effects. The emission factor models themselves were not modified. The adjustment factors were applied as constant values, with no variation due to temperature, speed, or other parameters. Temporal and spatial variations in estimated motor vehicle emissions from CNG fuel vehicles will therefore mirror the variations in emissions from gasoline fuel vehicles as predicted by MOBILE5a or EMFAC7F.

\subsection{Summary of Motor Vehicle Emission Analysis Results}

The estimated fleet-average RFG, LRVP gasoline, and CNG emissions factors for 2007 for Los Angeles and Atlanta are shown in Table 2-1. These emission factors have been derived using the EMFAC7F (Los Angeles) and MOVILE5a (Atlanta) emission models which assume operation within the bounds of the FTP test procedure. When comparing these emission factors for TOG, it is important to note that each fuel produces a very different suite of emitted compounds. For CNG fuel vehicles, 95 percent of TOG exhaust emissions are methane. Speciation profiles for motor vehicle emissions of TOG are provided in Appendix A. Tables 2-2 and 2-3 present the estimated emission adjustment factors for Atlanta and Los Angeles, respectively, developed using the methodology and data discussed in Appendix A.

Table 2-1. Light- and Medium-Duty Fleet Composite Average Exhaust

Emission Factors for FTP Operation for Year 2007

(units are grams/mile)

\begin{tabular}{lccc}
\hline Pollutant & $\begin{array}{c}\text { Los Angeles } \\
\text { RFG Baseline }\end{array}$ & $\begin{array}{c}\text { Atlanta } \\
\text { LRVP Baseline }\end{array}$ & CNG \\
\hline TOG & 0.27 & 0.85 & 0.55 \\
NO $_{x}$ & 0.53 & 1.1 & 0.20 \\
CO & 3.8 & 11.0 & 1.9 \\
\hline
\end{tabular}


Table 2-2. Exhaust Emission Adjustment Factors for Atlanta for Year 2007

\begin{tabular}{|c|c|c|c|c|c|}
\hline \multirow[b]{2}{*}{ Pollutant } & \multirow{2}{*}{$\begin{array}{l}\text { Vehicle } \\
\text { Type }^{\mathrm{a}}\end{array}$} & \multirow{2}{*}{$\begin{array}{l}\text { Off-FTP } \\
\text { Adjustment for } \\
\text { LRVP gasoline }\end{array}$} & \multicolumn{3}{|c|}{ CNG Adjustment Factors ${ }^{\mathfrak{b}}$} \\
\hline & & & $\begin{array}{c}\text { A } \\
\text { FTP } \\
\text { CNG/gasoline }\end{array}$ & $\begin{array}{c}\text { B } \\
\text { Off-FTP }\end{array}$ & $\begin{array}{l}\text { Total } \\
\mathbf{A}{ }^{*} \mathbf{B}\end{array}$ \\
\hline \multirow[t]{3}{*}{ TOG } & LDV & 1.3 & 0.68 & 1.1 & 0.74 \\
\hline & LDT & 1.2 & 0.63 & 1.1 & 0.69 \\
\hline & MDT & 1.3 & 0.56 & 1.1 & 0.62 \\
\hline \multirow[t]{3}{*}{$\mathrm{NO}_{x}$} & LDV & 2.0 & 0.19 & 1.5 & 0.29 \\
\hline & LDT & 1.8 & 0.18 & 1.5 & 0.27 \\
\hline & MDT & 1.6 & 0.20 & 1.5 & 0.30 \\
\hline \multirow[t]{3}{*}{ Co } & LDV & 2.7 & 0.16 & 2.1 & 0.33 \\
\hline & LDT & 2.2 & 0.15 & 2.1 & 0.31 \\
\hline & MDT & 2.4 & 0.28 & 2.1 & 0.58 \\
\hline
\end{tabular}

a Note: LDV = Light-duty gasoline vehicles

LDT = Light-duty gasoline trucks $(0-6,000$ pounds GVW)

MDT = Medium-duty gasoline trucks $(6,000-8,500$ pounds $G V W)$

- To obtain the adjusted exhaust emissions including off-FTP impacts for a given fuel, the FTP emission factor estimated using the IMOBILE5a emission model is multiplied by the appropriate adjustment factors. 
Table 2-3. Exhaust Emission Adjustment Factors for Los Angeles for Year 2007

\begin{tabular}{|c|c|c|c|c|c|c|}
\hline \multirow[b]{2}{*}{ Pollutant } & \multirow[b]{2}{*}{$\begin{array}{l}\text { Operating } \\
\text { Mode }\end{array}$} & \multirow[b]{2}{*}{$\begin{array}{c}\text { Vehicle } \\
\text { Type }\end{array}$} & \multirow{2}{*}{$\begin{array}{c}\text { RFG } \\
\text { Off-FTP } \\
\text { Adjustment }^{\mathrm{a}}\end{array}$} & \multicolumn{3}{|c|}{ CNG Adjustment factors } \\
\hline & & & & $\begin{array}{c}\text { A } \\
\text { CNG/RFG } \\
\text { for FTP }\end{array}$ & $\begin{array}{c}\text { B } \\
\text { Off-FTP } \\
\text { Adjustment }\end{array}$ & $\begin{array}{l}\text { Total } \\
(A * B)\end{array}$ \\
\hline \multirow[t]{3}{*}{ TOG } & Cold Start & $\begin{array}{l}\text { LDV } \\
\text { LDT } \\
\text { MDT }\end{array}$ & $\begin{array}{l}1.3 \\
1.2 \\
1.3\end{array}$ & $\begin{array}{l}0.95 \\
0.95 \\
0.95\end{array}$ & $\begin{array}{l}1.1 \\
1.1 \\
1.1\end{array}$ & $\begin{array}{l}1.0 \\
1.0 \\
1.0\end{array}$ \\
\hline & Hot Start & $\begin{array}{l}\text { LDV } \\
\text { LDT } \\
\text { MDT }\end{array}$ & $\begin{array}{l}1.3 \\
1.2 \\
1.3\end{array}$ & $\begin{array}{l}3.9 \\
3.9 \\
3.9\end{array}$ & $\begin{array}{l}1.1 \\
1.1 \\
1.1\end{array}$ & $\begin{array}{l}4.3 \\
4.3 \\
4.3\end{array}$ \\
\hline & $\begin{array}{l}\text { Hot } \\
\text { Stabilized }\end{array}$ & $\begin{array}{l}\text { LDV } \\
\text { LDT } \\
\text { MDT }\end{array}$ & $\begin{array}{l}1.3 \\
1.2 \\
1.3\end{array}$ & $\begin{array}{l}2.5 \\
2.5 \\
2.5\end{array}$ & $\begin{array}{l}1.1 \\
1.1 \\
1.1\end{array}$ & $\begin{array}{l}2.8 \\
2.8 \\
2.8\end{array}$ \\
\hline \multirow[t]{3}{*}{$\mathrm{NO}_{\mathbf{x}}$} & Cold Start & $\begin{array}{l}\text { LDV } \\
\text { LDT } \\
\text { MDT }\end{array}$ & $\begin{array}{l}2.0 \\
1.8 \\
1.6\end{array}$ & $\begin{array}{l}0.76 \\
0.76 \\
0.76\end{array}$ & $\begin{array}{l}1.5 \\
1.5 \\
1.5\end{array}$ & $\begin{array}{l}1.1 \\
1.1 \\
1.1\end{array}$ \\
\hline & Hot Start & $\begin{array}{l}\text { LDV } \\
\text { LDT } \\
\text { MDT }\end{array}$ & $\begin{array}{l}2.0 \\
1.8 \\
1.6\end{array}$ & $\begin{array}{l}0.38 \\
0.38 \\
0.38\end{array}$ & $\begin{array}{l}1.5 \\
1.5 \\
1.5\end{array}$ & $\begin{array}{l}0.57 \\
0.57 \\
0.57\end{array}$ \\
\hline & $\begin{array}{l}\text { Hot } \\
\text { Stabilized }\end{array}$ & $\begin{array}{l}\text { LDV } \\
\text { LDT } \\
\text { MDT }\end{array}$ & $\begin{array}{l}2.0 \\
1.8 \\
1.6\end{array}$ & $\begin{array}{l}0.27 \\
0.27 \\
0.27\end{array}$ & $\begin{array}{l}1.5 \\
1.5 \\
1.5\end{array}$ & $\begin{array}{l}0.41 \\
0.41 \\
0.41\end{array}$ \\
\hline \multirow[t]{3}{*}{$\mathrm{CO}$} & Cold Start & $\begin{array}{l}\text { LDV } \\
\text { LDT } \\
\text { MDT }\end{array}$ & $\begin{array}{l}2.7 \\
2.2 \\
2.4\end{array}$ & $\begin{array}{l}0.55 \\
0.55 \\
0.55\end{array}$ & $\begin{array}{l}2.1 \\
2.1 \\
2.1\end{array}$ & $\begin{array}{l}1.2 \\
1.2 \\
1.2\end{array}$ \\
\hline & Hot Start & $\begin{array}{l}\text { LDV } \\
\text { LDT } \\
\text { MDT }\end{array}$ & $\begin{array}{l}2.7 \\
2.2 \\
2.4\end{array}$ & $\begin{array}{l}1.10 \\
1.10 \\
1.10\end{array}$ & $\begin{array}{l}2.1 \\
2.1 \\
2.1\end{array}$ & $\begin{array}{l}2.3 \\
2.3 \\
2.3\end{array}$ \\
\hline & $\begin{array}{l}\text { Hot } \\
\text { Stabilized }\end{array}$ & $\begin{array}{l}\text { LDV } \\
\text { LDT } \\
\text { MDT }\end{array}$ & $\begin{array}{l}2.7 \\
2.2 \\
2.4\end{array}$ & $\begin{array}{l}0.39 \\
0.39 \\
0.39\end{array}$ & $\begin{array}{l}2.1 \\
2.1 \\
2.1\end{array}$ & $\begin{array}{l}0.82 \\
0.82 \\
0.82\end{array}$ \\
\hline
\end{tabular}

a To obtain the adjusted exhaust emissions including off-FTP impacts for a given fuel, the FTP emission factor estimated using the EMFAC7F emission model is multiplied by the appropriate adjustment factors.

The motor vehicle emissions estimates developed in this study are subject to significant limitations and uncertainties beyond those associated with emission estimates for conventional gasoline-fueled vehicles. Available test data to characterize emissions from CNG-fueled vehicles or from off-FTP operation of 
gasoline-fueled vehicles is quite limited. The emissions data and procedures used to develop the adjustment factors are described in detail in Appendix A. The primary data set used to develop CNG adjustment factors for FTP operation consists of zero mile test data from seven prototype vehicles (3 LDV and 4 MDV) and one LDV engine, tested on a dynamometer. For off-FTP operation of gasoline fuel vehicles, the primary emissions data bast: represents 525 vehicle tests of 34 light-duty automobiles and trucks. For CNG-fueled vehicles, only preliminary test data for off-FTP operation is available. From the available data, it is not feasible to develop emission factors or adjustment factors that accurately reflect variations in emissions by vehicle type and operating mode. The emissions estimation procedures employed for this study are intended only to cha:acterize the relative quantities of composite, fleet-average emissions for different fuel scenarios. Limitations and uncertainties inherent in our adjustment factors for on-FTP and off-FTP operation are summar zed in Tables 2-4 and 2-5.

Table 2-4. Summary of Identified On-FTP Estimate Limitations

Limitation
Potential Impact

Emission adjustment factors for CNG were only estimated at standard test conditions. Corrections for non-standard conditions such as speed and temperature existing in the EMFAC7F and MOBILE5a models were assumed to be applicable to CNG vehicles.

The vehicles on which the CVG test data were based are assumed to be representative of the fleet in general.

The amount of data available: for estimating ULEV-capable CNG vehicle deterioration rates was extremely limited.

CNG vehicle exhaust and evaporative speciation profiles were based on average gas composition. CNG composition is known to vary significantly.

Considerable variation in the individual species concentrations was seen in the RFG vehicle tests.
Potential over-estimate of CNG emissions due to changes in temperature.

Unknown.

Potentially significant impact of unknown direction and magnitude.

Moderate potential impact on photochemistry.

Moderate potential impact on photochemistry.

Table 2-5. Summary of Identified Off-FTP Estimate Limitations

Limi:ation

Potential Impact

Emission factors for the on-FTP portion were taken from the FTP test results of the vehicles.

Activity data used to compute the weighted average offFTP emission rates were basied on driving data collected from Atlanta during winter.

Off-FTP correction factors wise developed using speed and acceleration to represent engine load.

Emissions data were generatıd from a set of late model vehicles, tuned for correct orieration.
Moderate potential impact.

Moderate potential impact.

Unknown.

Unknown. 


\subsection{Emission Estimates for Greenhouse Gases and Air Toxics}

Greenhouse gas emissions for $\mathrm{CO}_{2}, \mathrm{CH}_{4}$, and nitrous oxide $\left(\mathrm{N}_{2} \mathrm{O}\right)$ from "affected" on-road mobile sources were calculated for the LRVP/RFG and CNG scenarios. "Affected" sources refer to passenger cars, LDTs and MDTs for which the emissions varied from one scenario to the next. Emissions from on-road mobile sources, heavy-duty gasoline trucks, all diesel vehicles, and motorcycles remained unchanged between scenarios and were therefore not included in this analysis.

For greenhouse gases, only domain-wide total emissions were calculated. The $\mathrm{CO}_{2}$ emissions from affected sources were calculated using emission factors based on mass of carbon per unit of fuel energy content. The remaining greenhouse gas emissions were calculated using three different methods based, respectively, on vehicle miles traveled (VMT), energy (British Thermal Unit, BTU) content of the fuel, and speciated results from the GEMAP emissions modeling. The estimates derived from direct speciation are preferred. The results for the other two methods are given for comparison purposes. Gridded, hourly emissions of air toxics consisting of BENZ, BUDI, ALD2, and FORM were also calculated for the affected on-road mobile sources, based on direct speciation of the GEMAP emissions modeling results. Details of the estimation of greenhouse gas and air toxic emissions are given in Appendix C.

\subsubsection{Emission Estimates for $\mathrm{CO}_{2}$}

Table 2-6 presents estimated $\mathrm{CO}_{2}$ emissions for 2007 for light- and medium-duty vehicles fueled by gasoline or CNG. The emission factors used are for natural gas and gasoline combustion (U.S. DOE 1994). We assumed that the gasoline emission factors are representative of emissions from the combustion of either RFG or LRVP gasoline. Implicit in the use of these emission factors is the assumption that all carbon in the fuel is combusted completely to $\mathrm{CO}_{2}$.

\subsubsection{Emission Estimates for $\mathrm{CH}_{4}$ and $\mathrm{N}_{2} \mathrm{O}$}

Emissions estimates for $\mathrm{CH}_{4}$ and $\mathrm{N}_{2} \mathrm{O}$ were calculated using three methods:

- Directly by the emissions modeling system (requires an assumed $\mathrm{N}_{2} \mathrm{O}$ to $\mathrm{NO}_{x}$ emission ratio to estimate $\mathrm{N}_{2} \mathrm{O}$ emissions).

- $\quad$ Emission factors based on energy consumption.

- Emission factors based on VMT.

Our preferred estimates of $\mathrm{CH}_{4}$ and $\mathrm{N}_{2} \mathrm{O}$ emissions are based on the speciation profiles for exhaust and evaporative emissions. Nitrous oxide emissions were estimated based on model-input $\mathrm{NO}_{\mathrm{x}}$ emissions. To obtain estimates of $\mathrm{N}_{2} \mathrm{O}$ for gasoline-fueled vehicles, the $\mathrm{NO}_{x}$ emissions were multiplied by 0.04 (U.S. EPA 1995). 
Table 2-6. Estimated Fuel Usage, Energy Usage, Carbon Emission Factors and $\mathrm{CO}_{2}$ Emission Rates for Los Angeles and Atlanta for Year 2007 for Light- ancl Medium-Duty Gasoline and CNG Fueled Vehicles

\begin{tabular}{cccccc}
\hline $\begin{array}{c}\text { Modeling } \\
\text { Domain }\end{array}$ & Fuel & $\begin{array}{c}\text { Gasoline } \\
\text { Usage } \\
\left(10^{6} \mathrm{Gal}\right. \\
\text { per day })\end{array}$ & $\begin{array}{c}\text { Energy } \\
\text { Usage } \\
\left(10^{12} \mathrm{BTU}\right. \\
\text { per day })\end{array}$ & $\begin{array}{c}\text { Emission } \\
\text { Factor } \\
\left(10^{6} \mathrm{MT} \mathrm{C}\right. \\
\left.\text { per } 10^{15} \mathrm{BTU}\right)\end{array}$ & $\begin{array}{c}\mathrm{CO}_{2} \\
\text { Emissions } \\
(\text { U.S. Tons } \\
\text { per day })^{\mathrm{a}}\end{array}$ \\
\hline Los Angeles & $\mathrm{RFCi}$ & $16.1^{\mathrm{a}}$ & 2.0 & $19.4^{\mathrm{b}}$ & 160,000 \\
& $\mathrm{CNG}$ & 16.1 & 2.0 & $14.5^{\mathrm{c}}$ & 120,000 \\
Atlanta & LRVI & $6.76^{\mathrm{d}}$ & 0.85 & $19.4^{\mathrm{b}}$ & 67,000 \\
& $\mathrm{CNCj}$ & 6.76 & 0.85 & $14.5^{\mathrm{c}}$ & 50,000 \\
\hline
\end{tabular}

a Source: BURDEN7F output for Los Angeles obtained from SCAOMD.

b Source: U.S. DOE, 1994. Table A4.

c Source: U.S. DOE, 1994. Table A3.

- Fuel usage based on an estimated VMT of $158 \times 10^{6}$ miles per day and an assumed average fuel economy of 23.4 miles per çallon based on BURDEN7F output for Los Angeles.

e All emissions are rounded to two or fewer significant figures.

For comparison purposes, we developed alternative estimates using two EPA emission factor approaches. Estimates of $\mathrm{CH}_{4}$ and $\mathrm{N}_{2} \mathrm{O}$ emissions using BTU-based and VMT-based factors are given in Tables 2-7 and 2-8 for Los Angeles and Atlanta, respectively. Both sets of emission factors were developed by U.S. EPA, but the BTU-based emission factors are preferred because, unlike the VMT-based factors, they do not require an inherent assumption of fuel economy (U.S. EPA 1995). For both cities, the speciation-based $\mathrm{CH}_{4}$ emissions for the $\mathrm{CNG}$ scenario are significantly lower than those estimated using emission factors, while $\mathrm{CH}_{4}$ estimates for the RFCi/LRVP scenarios are higher. For $\mathrm{N}_{2} \mathrm{O}$, the trend is mixed with emission factors producing higher estimates for the Los Angeles scenario while the modeling approach produces higher $\mathrm{N}_{2} \mathrm{O}$ emission for the Atlanta gasoline scenario. The inconsistent trend and large differences in the model and emission factor estimates indicate there is significant uncertainty in these estimates of greenhouse gas emissions.

Table 2-7. Estimated $\mathrm{CH}_{4}$ and $\mathrm{N}_{2} \mathrm{O}$ Emissions from Affected

On-Ruad Mobile Sources in Los Angeles (tons/day)

\begin{tabular}{cccccc}
\hline & & & \multicolumn{2}{c}{ Alternative Estimates } \\
Pollutant & $\begin{array}{c}\text { Modeling } \\
\text { Scenario }\end{array}$ & $\begin{array}{c}\text { Preferred Estimate } \\
\text { (Speciation) }\end{array}$ & BTU-Based & VMT-Based \\
\hline \multirow{2}{*}{$\mathrm{CH}_{4}$} & RFG & 30 & 19 & 18 \\
& CNG & 200 & 620 & 520 \\
\multirow{2}{*}{$\mathrm{N}_{2} \mathrm{O}$} & RFG & 8 & 15 & 15 \\
& CNG & 0 & 0 & 0 \\
\hline
\end{tabular}

Note: All emission estimates are rounded to two or fewer significant figures 
Table 2-8. Estimated $\mathrm{CH}_{4}$ and $\mathrm{N}_{2} \mathrm{O}$ Emissions from Affected

On-Road Mobile Sources in Atlanta (tons/day)

\begin{tabular}{ccccc}
\hline & & & \multicolumn{2}{c}{ Alternative Estimates } \\
\cline { 5 - 5 } Pollutant & $\begin{array}{c}\text { Modeling } \\
\text { Scenario }\end{array}$ & $\begin{array}{c}\text { Preferred Estimate } \\
\text { (Speciation) }\end{array}$ & BTU-Based & VMT-Based \\
\hline $\mathrm{CH}_{4}$ & LRVP & 25 & 8.0 & 7.4 \\
& CNG & 140 & 260 & 200 \\
\multirow{2}{*}{$\mathrm{N}_{2} \mathrm{O}$} & LRVP & 15 & 6.3 & 6.0 \\
& CNG & 0 & 0 & 0 \\
\hline
\end{tabular}

Note: All emission estimates are rounded to two or fewer significant figures

\subsubsection{Emission Estimates for Air Toxics}

Air toxics emissions of BUDI, BENZ, ALD2, and FORM were estimated both as gridded, hourly model input species and as daily totals for the entire Los Angeles and Atlanta modeling domains.

The air toxics emissions estimates presented in Table 2-9 for Los Angeles and Atlanta were calculated similarly to the $\mathrm{CH}_{4}$ emissions. These chemicals are calculated from the speciated TOG emissions for each fuel scenario. The results presented in this table indicate that the CNG scenario is associated with lower estimates of primary emissions of all four air toxics compounds for both modeling domains.

Table 2-9. Estimated Air Toxic Emissions from Affected On-Road Mobile Sources in Los Angeles and Atlanta (tons/day)

\begin{tabular}{cccccc}
\hline Area & $\begin{array}{c}\text { Modeling } \\
\text { Scenario }\end{array}$ & Benzene & 1-, 3-Butadiene & Acetaldehyde & Formaldehyde \\
\hline Los & RFG & 5.7 & 0.28 & 0.25 & 0.80 \\
Angeles & CNG & 0.03 & 0.02 & 0.02 & 0.15 \\
& & & & & \\
\multirow{2}{*}{ Atlanta } & LRVP & 8.2 & 0.88 & 0.88 & 1.9 \\
& CNG & 0.02 & 0.01 & 0.01 & 0.11 \\
\hline
\end{tabular}

Note: All emission estimates are rounded to two or fewer significant figures. 


\subsection{Development and Testing of a Toxics CBM-IV Chemical Mechanism for UAM-IV}

In order to estimate ambient concentrations and exposures for identified air toxics compounds contained in motor vehicle emissions, it was necessary to modify the chemical mechanism in UAM-IV. The identification of acetaldehyde (ACET) as a toxic chemical of concern required that the chemical lumping of higher aldehydes in the present version of the CBM-IV mechanism be revised in order to break out ACET as a separate chemical species. This disaggregation requires significant changes in the CBM-IV mechanism used in UAM-IV version 6.21. Other changes are required for better simulation of gas phase chemistry for the toxic species BENZ and BUDI. These revisions to the CBM-IV chemistry were made by Killus (1995) for this project and are described below. The modifications to the chemical mechanism produce changes in predicted ozone concentrations. A series of tests were conducted to ensure that the new mechanism was operating properly and to document and quantify any predicted changes in ozone photochemistry.

\subsection{Modifications of the CBM-IV Surrogate Approximation}

The technique of "surrogate approximation" is used in the CBM-IV mechanism to reduce the number of state (transported) species. It is common in atmospheric models to account for a group of chemically-similar compounds by using a single compound as a "surrogate", e.g., using propene as a surrogate for all 1-olefins (OLE). UAM also uses another form of surrogate approximation, by treating a number of highly reactive compounds as if they had already reacted to form products. Thus, a very reactive compound such as cis-2-butene can be approximated as an emission of two molecules of its reaction product ACET. Tests have shown the UAM surrogate approximation technique to give adequate results in most situations.

The present highly aggregated version of the Carbon Bond chemical reaction mechanism known as CBM-IV has 10 primary organic species. Three of these species are highly lumped surrogates: paraffins (PAR), OLE, and ALD2, representing ACET and higher aldehydes (HALD). The other explicit surrogate chemical species include FORM, toluene (TOL), xylene (XYL), isoprene (ISOP), ethene (ETH), and the alcohols ethanol (ETOH), and methanol (MEOH). The complete chemical mechanism has 33 species and is represented by 86 chemical reactions. The new toxics CBM-IV mechanism has 42 species, as listed in Table 3-1, and 109 chemical reactions. The complete chemical mechanism is documented in Table 3-2. The last 9 species listed in Table 3-1 and the last 23 reactions in Table 3-2 are those added for the new mechanism. With the introduction of new species (ACET, IOLE, HALD, HPAN, $\mathrm{C}_{3} \mathrm{O}_{3}$ ) the related reactions in the original mechanism have also been modified.

The explicit treatment of ACET in UAM is not straightforward because the original formulation lumped all non-formaldehyde aldehyde species into a single category. It is necessary to distinguish ACET both from other higher aldehyde species and from reactive compounds that form ACET. This change was accomplished by adding two new "species": HALD, for other higher aldehydes, and IOLE, for internal olefins such as cis-2-butene and trans-2-butene, which form ACET as a reaction product. The addition of HALD, in turn, requires a new species "HPAN" to represent the PAN-analog reaction products of HALD.

The photolysis rate for ACET is considerably smaller than the rate for other higher aldehydes (Moortgat et al., 1989). With a smaller photolysis rate, ACET will react more slowly, which can result in higher predicted ACET concentrations and lower concentrations of radicals produced via photolysis. For the new species IOLE, a new set of chemical reactions (Reactions 89 to 92 in Table 3-2) was added to the chemical mechanism, based on Atkinson et al (1994) and Atkinson (1990). The reaction pathways to form HALD 
from OLE and PAR are based on similar product pathways in the original CBM-IV mechanism (Geary et al., 1988).

Three air toxics compounds, BENZ, BUDI, and acrolein (ACRO), were installed as "ghost" state variables, with no feedback to $\mathrm{O}_{3}$ photoch $\mathrm{mistry}$. The emission and decay of these compounds is described explicitly, while their effects on $\mathrm{O}_{3}$ photochemistry are treated via their contributions to the Carbon Bond surrogates already in the model. The "ghcist" variable approach will give reasonable results as long as the species in question is a relatively minor constituent of a class of compounds and is not itself a reaction product. The simplifying assumption of "ghost" species makes the addition of BENZ, BUDI, and ACRO to the UAM chemistry routines, and the testing of those additions, both simple and straightforward. Reactions for the "ghost" species are numbered 87, and 99 through 103 in Table 3-2. They have no effect on the chemistry, and will track concentrations of the three compounds so long as the reacting species $\left(\mathrm{OH}, \mathrm{O}_{3}\right.$, and $\left.\mathrm{NO}_{3}\right)$ are correctly simulated.

Three chemical reactions involving propane and acetone (Reactions 104-106) were also added to the toxics chemical mechanism and are listed in Table 3-2. For the present study, these reaction have been disabled, since they do not involve any toxic species of concern.

\subsection{Testing of the CBM-TV Toxics Chemical Mechanism}

The implementation of the chan zes to the CBM-IV chemistry for this project has been tested under a variety of conditions. The modified chemical mechanism solver was installed in a chemical box model, BOXCHEM, which functions as a numerical smog chamber. The results for a series of test cases are discussed in Killus (1995). The testing indicates that predicted peak ozone is reduced slightly for the revised mechanism, compared to the urmodified CBM-IV chemistry.

The BOXCHEM model was exercised in two modes. In the first mode, the compounds were introduced as initial conditions with no emissions. In the second mode, emissions were input as $30 \%$ of the initial conditions for each time step. The BOXCHEM was operated for both nighttime (zero photolysis) and midday conditions. The most relevant tests were for midday conditions. During these midday tests the chamber was operated for a 6 -hour simulation period in the afternoon with a constant temperature of $298^{\circ} \mathrm{K}$ and water vapor concentration (a source of hydroxyl radicals) of $20,000 \mathrm{ppm}$. An error tolerance was set to $1 \%$ for $\mathrm{NO}$ and $\mathrm{HO}_{2}$. The predicted concentrations were saved every 30 minutes as a period ending snapshot.

Plots of the modeled concentration for midday conditions for seven chemical species are given in Figure 3-1 for each type of BOXCHEM sinulation. The ending digit of the simulation identifier (see legend box in the lower right of the figure) indicates the mode in which BOXCHEM was exercised. Figure 3-1a indicates that typically $5-8 \%$ more ozone is produced by the original unmodified chemistry. Also, there is no effective difference between simulations with and without "ghost" species toxics as was expected.

Differences in ozone production are reflected in changes in the nitrogen chemistry. In the new chemical scheme, there are 10 chemical species (including nitrate and excluding NTR) and 9 in the old scheme. The new addition is the higher PAIN analogs (HPAN). Of all the species, all but a percent or so of the total nitrogen is sequestered in the ' $A N s, \mathrm{HNO}_{3}, \mathrm{~N}_{2} \mathrm{O}_{5}, \mathrm{NO}_{2}$, AND NO. A summary of the nitrogen species concentrations at the end of the 15-hour afternoon simulation is shown in Table 3-3. The table indicates that the TOXIC chemistry scheme re sults in less $\mathrm{NO}_{\mathrm{x}}$ to participate in ozone chemistry. One reason is that HPAN facilitates the conversion of $\mathrm{NO}_{\mathrm{x}}$ to a nitrate and represents a significant nitrogen reservoir, as shown in Table 3-3. 
The time versus concentration plots for $\mathrm{NO}_{2}$ and PAN are shown in Figures 3-1b and 3-1c, respectively. For all of the test cases the $\mathrm{NO}_{2}$ initially jumps then decays with the passage of time. The rate of decrease is larger for the toxics chemistry. The decrease in the rate of PAN formation (and buildup) in the toxics chemistry case is evident.

The radical $(\mathrm{OH})$ concentrations were examined. Figure 3-1d shows that the expanded CBM chemical mechanism results in lower radical concentrations regardless of the presence of emission species. The situation is a little more complicated for the peroxy radicals $\left(\mathrm{C}_{2} \mathrm{O}_{3}\right)$. When emissions of peroxy radicals are added, the time series in Figure 3-1e indicates that for some times more peroxy radicals are present under the expanded CBM scheme than the original, but at the end of the experiment more radicals are produced with the original chemistry.

In the base simulation, ALD2 contains all of the aldehydes other than formaldehyde. In the case of the toxics chemistry, ALD2 only contains acetaldehyde, with all remaining higher aldehydes lumped into HALD. The time series of ALD2 is given in Figure 3-1f. An interesting finding is that there is more acetaldehyde as ALD2 in the expanded CBM simulations than all of the aldehydes present in ALD2 in the base simulation. The reduced photolysis for acetaldehyde (ACET) relative to the larger photolysis in the original CBM higher aldehydes (ALD2) contributes to the overall increase in total aldehyde concentrations in the expanded CBM chemistry. The slower photolytic destruction results in fewer radicals being formed.

The reactions of the "ghost" toxic species such as benzene and 1,3-butadiene was examined. The time series of benzene is shown in Figure 3-1g. Benzene reacts very slowly, so there is essentially very little difference between the cases when benzene is and is not allowed to react. When the toxics switch is enabled, the 1-3butadience concentrations plunge from $3.0 \times 10^{-3} \mathrm{ppm}$ at the start of the experiment to $1.3 \times 10^{-5}$ six hours later.

Table 3-1. Chemical Species in the Toxics Version of the CBM-IV Mechanism

\begin{tabular}{|c|c|}
\hline Species Name & Representation \\
\hline Nitric oxide & NO \\
\hline Nitrogen dioxide & $\mathrm{NO}_{2}$ \\
\hline Nitrogen trioxide (nitrate radical) & $\mathrm{NO}_{3}$ \\
\hline Dinitrogen pentoxide & $\mathrm{N}_{2} \mathrm{O}_{5}$ \\
\hline Nitrous acid & HONO \\
\hline Nitric acid & $\mathrm{HNO}_{3}$ \\
\hline Peroxynitric acid $\left(\mathrm{HO}_{2} \mathrm{NO}_{2}\right)$ & PNA \\
\hline Oxygen atom (singlet) & $0^{1} \mathrm{D}$ \\
\hline Oxygen atom (triplet) & $\mathrm{O}$ \\
\hline Hydroxyl radical & $\mathrm{OH}$ \\
\hline Water & $\mathrm{H}_{2} \mathrm{O}$ \\
\hline Ozone & $\mathrm{O}_{3}$ \\
\hline Hydroperoxy radical & $\mathrm{HO}_{2}$ \\
\hline Hydrogen peroxide & $\mathrm{H}_{2} \mathrm{O}_{2}$ \\
\hline
\end{tabular}


Carbon monoxide

$\mathrm{CO}$

Formaldehyde $\left(\mathrm{CH}_{2} \mathrm{O}\right)$

FORM

Acetaldhyde (RCHO)

ACET

Peroxyacyl radical $\left(\mathrm{CH}_{3} \mathrm{C}(\mathrm{O}) \mathrm{OO} \cdot\right)$

$\mathrm{C}_{2} \mathrm{O}_{3}$

Peroxyacyl nitrate $\left(\mathrm{CH}_{3} \mathrm{C}(\mathrm{O}) \mathrm{OONO}\right.$.)

PAN

Paraffin carbon bond (C-C)

PAR

Secondary organic oxy radical

ROR

Olefinic carbon bond $(\mathrm{C}=\mathrm{C})$

OLE

Ethene $\left(\mathrm{CH}_{2}=\mathrm{CH}_{2}\right)$

ETH

Toluene $\left(\mathrm{C}_{6} \mathrm{H}_{5}-\mathrm{CH}_{3}\right)$

TOL

Cresol and higher molecular weight shenols

CRES

Toluene-hydroxyl radical adduct

$\mathrm{TO}_{2}$

Methylphenoxy radical

CRO

High molecular weight aromatic oxilation ring fragment

OPEN

Xylene $\left(\mathrm{C}_{6} \mathrm{H}_{4}-\left(\mathrm{CH}_{3}\right)_{2}\right)$

$\mathrm{XYL}$

Methylglyoxal $\left(\mathrm{CH}_{3} \mathrm{C}(\mathrm{O}) \mathrm{C}(\mathrm{O}) \mathrm{H}\right)$

MGLY

Isoprene

ISOP

NO-to- $\mathrm{NO}_{2}$ operation

$\mathrm{XO}_{2}$

NO-to-nitrate operation

$\mathrm{XO}_{2} \mathrm{~N}$

Sulfate

SULF

Nitrate

NTR

Internal olefins

IOLE

Higher PAN anlogs (e.g.PPN)

HPAN

Higher aldehydes $\left(\mathrm{R}_{n} \mathrm{CHO}\right)$

HALD

Benzene $\left(\mathrm{C}_{6} \mathrm{H}_{6}\right)$

BENZ

1-, 3-butadiene $\left(\left(\mathrm{CH}_{2}\right)_{2} \mathrm{CHCH}\right)$

BUDI

Acrolein $\left(\mathrm{CH}_{2} \mathrm{CFORM}\right)$

ACRO

Propane $\left(\mathrm{C}_{3} \mathrm{H}_{8}\right)$

PRPA

Acetone $\left(\mathrm{CH}_{3} \mathrm{COCH}_{3}\right)$

AONE

Higher peroxacyl radicals

$\mathrm{C}_{3} \mathrm{O}_{3}$

Total number of chemical species 
Table 3.2 The Toxics version of the Carbon Bond Mechanism IV

\begin{tabular}{|c|c|c|c|c|}
\hline $\begin{array}{l}\text { Reaction } \\
\text { No. }\end{array}$ & Reaction & $\begin{array}{l}\text { Pre-factor } \\
\mathrm{ppm}^{-\mathrm{n}} \mathrm{hr}^{-1}\end{array}$ & $\begin{array}{l}\text { Temperature } \\
\text { dependency }\end{array}$ & $\begin{array}{l}\text { Rate constant at } 298 \mathrm{~K} \\
\mathrm{ppm}^{-2} \mathrm{hr}^{-1}\end{array}$ \\
\hline \multicolumn{5}{|c|}{ Inorganic Reactions } \\
\hline (R1) & $\mathrm{NO}_{2}+\mathrm{hv}+\mathrm{NO}+\mathrm{O}$ & radiation dependent & none & na \\
\hline (R2) & $\mathrm{O}+\mathrm{O}_{2}+\mathrm{M} \rightarrow \mathrm{O}_{3}+\mathrm{M}$ & $0.503 \mathrm{E}+07$ & $e^{1175 / \pi}$ & $0.600 \mathrm{E}+02$ \\
\hline (R3) & $\mathrm{O}_{3}+\mathrm{NO} \rightarrow \mathrm{NO}_{2}+\mathrm{O}_{2}$ & $0.155 \mathrm{E}+06$ & $e^{-1370 / r}$ & $0.160 \mathrm{E}+04$ \\
\hline (R4) & $\mathrm{O}+\mathrm{NO}_{2}+\mathrm{NO}+\mathrm{O}_{2}$ & $0.825 E+05$ & none & $0.825 \mathrm{E}+06$ \\
\hline (R5) & $\mathrm{O}+\mathrm{NO}_{2}+\mathrm{M} \rightarrow \mathrm{NO}_{3}+\mathrm{M}$ & $0.138 \mathrm{E}+05$ & $e^{687 / T}$ & $0.139 \mathrm{E}+06$ \\
\hline (R6) & $\mathrm{O}+\mathrm{NO}+\mathrm{M} \rightarrow \mathrm{NO}_{2}+\mathrm{M}$ & $0.194 \mathrm{E}+05$ & $e^{602 \pi}$ & $0.146 \mathrm{E}+06$ \\
\hline (R7) & $\mathrm{O}_{3}+\mathrm{NO}_{2} \rightarrow \mathrm{NO}_{3}+\mathrm{O}_{2}$ & $0.106 \mathrm{E}-05$ & $\mathrm{e}^{-2450 / \mathrm{T}}$ & $0.284 \mathrm{E}+01$ \\
\hline (R8) & $\mathrm{O}_{3}+\mathrm{hv} \rightarrow \mathrm{O}+\mathrm{O}_{2}$ & radiation dependent & none & na \\
\hline (R9) & $\mathrm{O}_{3}+\mathrm{h} v \rightarrow \mathrm{O}^{\prime} \mathrm{D}$ & radiation dependent & none & na \\
\hline (R10) & $\mathrm{O}^{\prime} \mathrm{D}+\mathrm{M} \rightarrow \mathrm{O}+\mathrm{M}$ & $0.688 \mathrm{E}+07$ & $e^{390 / \pi}$ & $0.255 E+08$ \\
\hline (R11) & $\mathrm{O}^{\prime} \mathrm{D}+\mathrm{H}_{2} \mathrm{O} \rightarrow 2 \mathrm{OH}$ & $0.196 \mathrm{E}+03$ & none & $0.196 \mathrm{E}+03$ \\
\hline (R12) & $\mathrm{O}_{3}+\mathrm{OH} \rightarrow \mathrm{HO}_{2}+\mathrm{O}_{2}$ & $0.141 \mathrm{E}+06$ & $e^{-940 / \pi}$ & $0.600 \mathrm{E}+04$ \\
\hline (R13) & $\mathrm{O}_{3}+\mathrm{HO}_{2} \rightarrow \mathrm{OH}+2 \mathrm{O}_{2}$ & $0.126 \mathrm{E}+04$ & $\mathrm{e}^{-.580 / \mathrm{T}}$ & $0.180 \mathrm{E}+03$ \\
\hline (R14) & $\mathrm{NO}_{3}+\mathrm{hv} \rightarrow 0.89 \mathrm{NO}_{2}+0.89 \mathrm{O}+0.11 \mathrm{NO}$ & radiation dependent & none & na \\
\hline (R15) & $\mathrm{NO}_{3}+\mathrm{NO} \rightarrow 2 \mathrm{NO}_{2}$ & $0.115 \mathrm{E}+07$ & $\mathrm{e}^{250 / \mathrm{T}}$ & $0.265 \mathrm{E}+07$ \\
\hline (R16) & $\mathrm{NO}_{3}+\mathrm{NO}_{2} \rightarrow \mathrm{NO}+\mathrm{NO}_{2}+\mathrm{O}_{2}$ & $0.220 \mathrm{E}+04$ & $e^{-1230 / \pi}$ & $0.354 \mathrm{E}+02$ \\
\hline (R17) & $\mathrm{NO}_{3}+\mathrm{NO}_{2}+\mathrm{M} \rightarrow \mathrm{N}_{2} \mathrm{O}_{5}+\mathrm{M}$ & $0.471 \mathrm{E}+05$ & $e^{256 / \pi}$ & $0.111 \mathrm{E}+06$ \\
\hline (R18) & $\mathrm{N}_{2} \mathrm{O}_{5}+\mathrm{H}_{2} \mathrm{O} \rightarrow 2 \mathrm{HNO}_{3}$ & $0.114 \mathrm{E}-03$ & none & $0.114 \mathrm{E}-03$ \\
\hline (R19) & $\mathrm{N}_{2} \mathrm{O}_{3}+\mathrm{M} \rightarrow \mathrm{NO}_{3}+\mathrm{NO}_{2}+\mathrm{M}$ & $0.127 \mathrm{E}-19$ & $\mathrm{e}^{-10897 \pi \mathrm{T}}$ & $0.167 \mathrm{E}+03$ \\
\hline (R20) & $\mathrm{NO}+\mathrm{NO}+\mathrm{O}_{2} \rightarrow 2 \mathrm{NO}_{2}$ & $0.156 \mathrm{E}-02$ & $e^{330 / T}$ & $0.923 E-02$ \\
\hline (R21) & $\mathrm{NO}+\mathrm{NO}_{2}+\mathrm{H}_{2} \mathrm{O} \rightarrow 2 \mathrm{HONO}$ & $0.960 \mathrm{E}-09$ & none & $0.960 \mathrm{E}-09$ \\
\hline (R22) & $\mathrm{OH}+\mathrm{NO} \rightarrow \mathrm{HONO}$ & $0.383 E+05$ & $e^{806 / T}$ & $0.588 \mathrm{E}+06$ \\
\hline
\end{tabular}




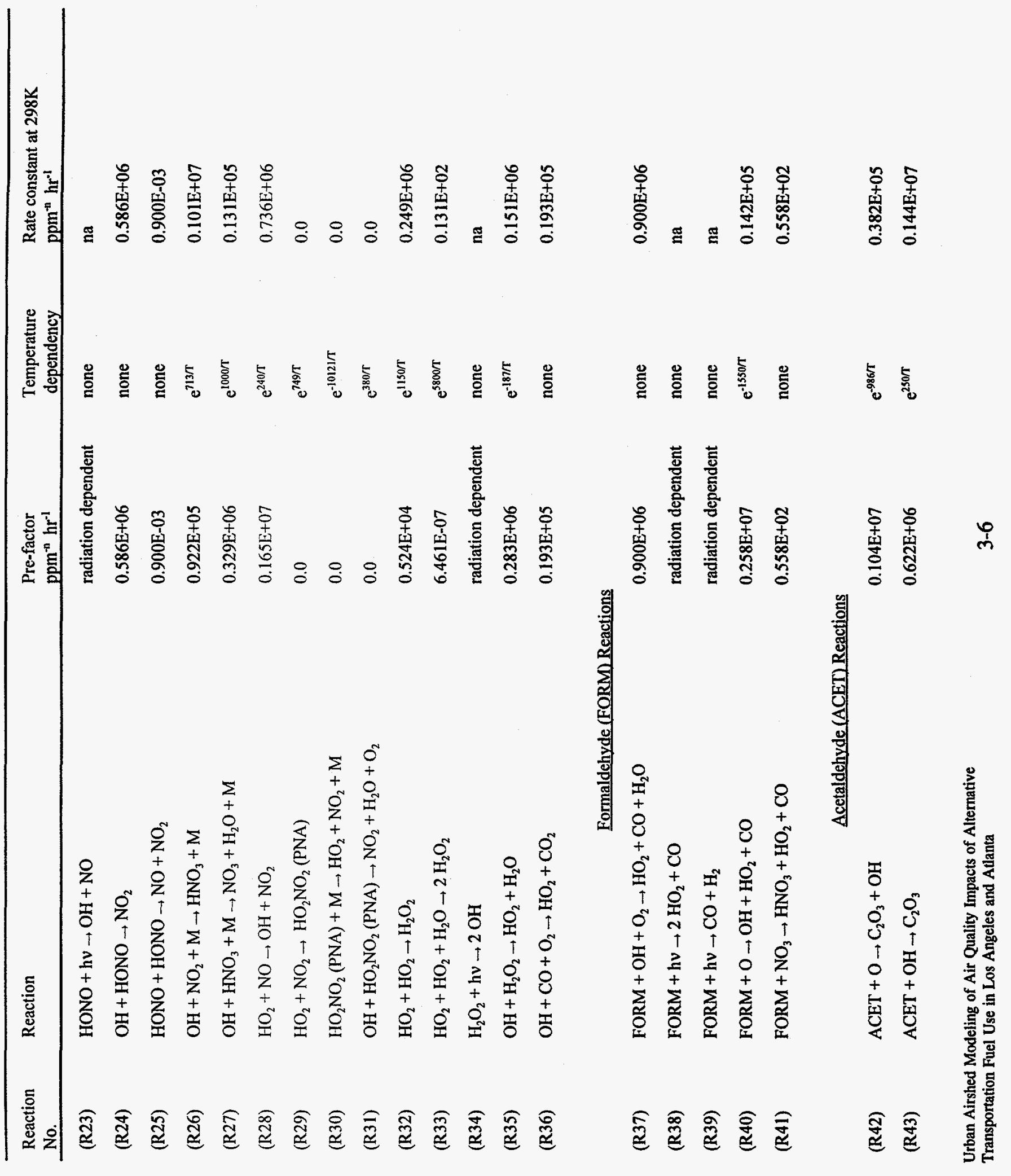




\begin{tabular}{|c|c|c|c|c|}
\hline $\begin{array}{l}\text { Reaction } \\
\text { No. }\end{array}$ & Reaction & $\begin{array}{l}\text { Pre-factor } \\
\mathrm{ppm}^{-\mathrm{n}} \mathrm{hr}^{-1}\end{array}$ & $\begin{array}{l}\text { Temperature } \\
\text { dependency }\end{array}$ & $\begin{array}{l}\text { Rate constant at } 298 \mathrm{~K} \\
\mathrm{ppm}^{-n} \mathrm{hr}^{-1}\end{array}$ \\
\hline (R44) & $\mathrm{ACET}+\mathrm{NO}_{3} \stackrel{\mathrm{O}_{2}}{\longrightarrow} \mathrm{C}_{2} \mathrm{O}_{3}+\mathrm{HNO}_{3}$ & $0.2222 \mathrm{E}+03$ & none & $0.222 \mathrm{E}+03$ \\
\hline$(\mathrm{R} 45)$ & $\mathrm{ACET}+\mathrm{hv} \stackrel{2 \mathrm{O}_{2}}{\longrightarrow} \mathrm{FORM}+\mathrm{XO}_{2}+\mathrm{CO}+2 \mathrm{HO}_{2}$ & radiation dependent & & \\
\hline (R46) & $\mathrm{C}_{2} \mathrm{O}_{3}+\mathrm{NO} \stackrel{\mathrm{O}_{2}}{\longrightarrow} \mathrm{FORM}+\mathrm{XO}_{2}+\mathrm{HO}_{2}+\mathrm{NO}_{2}$ & $0.310 \mathrm{E}+07$ & $\mathrm{e}^{-180 \mathrm{~T}}$ & $0.169 \mathrm{E}+07$ \\
\hline (R47) & $\mathrm{C}_{2} \mathrm{O}_{3}+\mathrm{NO}_{2} \rightarrow \mathrm{PAN}$ & $0.230 \mathrm{E}+06$ & $e^{380 / T}$ & $0.822 \mathrm{E}+06$ \\
\hline (R48) & $\mathrm{PAN} \rightarrow \mathrm{C}_{2} \mathrm{O}_{3}+\mathrm{NO}_{2}$ & $0.720 \mathrm{E}-20$ & $\mathrm{e}^{-13500 / \mathrm{T}}$ & $0.152 \mathrm{E}+01$ \\
\hline$(\mathrm{R} 49)$ & $\mathrm{C}_{2} \mathrm{O}_{3}+\mathrm{C}_{2} \mathrm{O}_{3} \rightarrow 2 \mathrm{FORM}+2 \mathrm{XO}_{2}+2 \mathrm{HO}_{2}$ & $0.222 \mathrm{E}+06$ & none & $0.222 \mathrm{E}+06$ \\
\hline (R50) & $\begin{array}{l}\mathrm{C}_{2} \mathrm{O}_{3}+\mathrm{HO}_{2} \rightarrow 0.79 \mathrm{FORM}+0.79 \mathrm{XO}_{2}+0.79 \mathrm{HO}_{2} \\
0.79 \mathrm{OH}\end{array}$ & $0.576 E+06$ & none & $0.576 \mathrm{E}+06$ \\
\hline (R51) & $\mathrm{OH} \rightarrow \mathrm{FORM}+\mathrm{XO}_{2}+\mathrm{HO}_{2}$ & $0.391 E+06$ & $\mathrm{e}^{-1710 \mathrm{r} T}$ & $0.126 \mathrm{E}+04$ \\
\hline \multicolumn{5}{|c|}{ Alkane Reactions } \\
\hline (R52) & $\begin{array}{l}\mathrm{PAR}+\mathrm{OH} \rightarrow 0.87 \mathrm{XO}_{2}+0.13 \mathrm{XO}_{2} \mathrm{~N}+0.11 \mathrm{HO}_{2} \\
+0.06 \mathrm{ACET}+0.76 \mathrm{ROR}-0.11 \mathrm{PAR}+0.05 \mathrm{HALD}\end{array}$ & $0.722 \mathrm{E}+05$ & none & $0.722 E+05$ \\
\hline \multirow[t]{2}{*}{ (R53) } & \multirow[t]{2}{*}{$\begin{array}{l}\mathrm{ROR} \rightarrow 0.6 \mathrm{ACET}+0.96 \mathrm{XO}_{2}+0.94 \mathrm{HO}_{2}+0.04 \mathrm{XO}_{2} \mathrm{~N} \\
+0.02 \mathrm{ROR}-2.10 \mathrm{PAR}+0.5 \mathrm{HALD}\end{array}$} & & & \\
\hline & & $0.375 \mathrm{E}+19$ & $\mathrm{e}^{-8000 \pi}$ & $0.823 E+07$ \\
\hline (R54) & $\mathrm{ROR} \rightarrow \mathrm{HO}_{2}$ & $0.573 \mathrm{E}+07$ & none & $0.573 \mathrm{E}+07$ \\
\hline (R55) & $\mathrm{ROR}+\mathrm{NO}_{2} \rightarrow$ & $0.132 \mathrm{E}+07$ & none & $0.132 E+07$ \\
\hline \multicolumn{5}{|c|}{ Alkene Reactions } \\
\hline \multirow[t]{2}{*}{ (R56) } & $\begin{array}{l}\mathrm{O}+\mathrm{OLE} \rightarrow 0.32 \mathrm{ACET}+0.38 \mathrm{HO}_{2}+0.28 \mathrm{XO}_{2} \\
+0.30 \mathrm{CO}+0.20 \mathrm{FORM}+0.02 \mathrm{X0}_{2} \mathrm{~N}+0.22 \mathrm{PAR} \\
+0.20 \mathrm{OH}+0.31 \mathrm{HALD}\end{array}$ & & & \\
\hline & & $0.105 E+07$ & $\mathrm{e}^{-324 \pi}$ & $0.355 \mathrm{E}+06$ \\
\hline (R57) & $\begin{array}{l}\mathrm{OH}+\mathrm{OLE} \rightarrow \mathrm{FORM}+0.5 \mathrm{ACET}+\mathrm{XO}_{2}+\mathrm{HO}_{2}-\mathrm{PAR} \\
+0.5 \mathrm{HALD}\end{array}$ & $0.464 \mathrm{E}+06$ & $\mathrm{e}^{304 / T}$ & $0.252 \mathrm{E}+07$ \\
\hline
\end{tabular}




\begin{tabular}{|c|c|c|c|c|}
\hline $\begin{array}{l}\text { Reaction } \\
\text { No. }\end{array}$ & Reaction & $\begin{array}{l}\text { Pre-factor } \\
\mathrm{ppm}^{-n} \mathrm{hr}^{-1}\end{array}$ & $\begin{array}{l}\text { Temperature } \\
\text { dependency }\end{array}$ & $\begin{array}{l}\text { Rate constant at 298K } \\
\mathrm{ppm}^{-n} \mathrm{hr}^{-1}\end{array}$ \\
\hline (R58) & $\begin{array}{l}\mathrm{O}_{3}+\mathrm{OLE} \rightarrow 0.25 \mathrm{ACET}+0.74 \mathrm{FORM}+0.33 \mathrm{CO} \\
+0.44 \mathrm{HO}_{2}+0.25 \mathrm{HALD}+0.22 \mathrm{XO}_{2}+0.10 \mathrm{OH} \cdot \mathrm{PAR}\end{array}$ & $0.126 \mathrm{E}+04$ & $e^{-210 s / T}$ & $0.138 \mathrm{E}+01$ \\
\hline (R59) & $\begin{array}{l}\mathrm{NO}_{3}+\mathrm{OLE} \rightarrow 0.91 \mathrm{OL}_{2}+\mathrm{FORM}+0.5 \mathrm{ACET} \\
+0.09 \mathrm{XO}_{2} \mathrm{~N}+\mathrm{NO}_{2} \cdot \mathrm{PAR}+0.5 \mathrm{HALD}\end{array}$ & $0.681 \mathrm{E}+03$ & none & $0.681 \mathrm{E}+03$ \\
\hline (R60) & $\begin{array}{l}\mathrm{O}+\mathrm{ETH} \rightarrow \mathrm{FORM}+0.70 \mathrm{XO}_{2}+\mathrm{CO}+1.70 \mathrm{HO}_{2} \\
+0.30 \mathrm{OH}\end{array}$ & $0.924 \mathrm{E}+06$ & $e^{-792 \pi}$ & $0.648 \mathrm{E}+05$ \\
\hline (R61) & $\mathrm{OH}+\mathrm{ETH} \rightarrow \mathrm{XO}_{2}+1.56 \mathrm{FORM}+\mathrm{HO}_{2}+0.22 \mathrm{HALD}$ & $0.180 \mathrm{E}+06$ & $e^{411 / \pi}$ & $0.715 \mathrm{E}+06$ \\
\hline (R62) & $\mathrm{O}_{3}+\mathrm{ETH} \rightarrow \mathrm{FORM}+0.42 \mathrm{CO}+0.12 \mathrm{HO}_{2}$ & $6.111 \mathrm{E}+04$ & $e^{-2633 \pi}$ & $0.162 \mathrm{E}+00$ \\
\hline \multicolumn{5}{|c|}{ Aromatic Reactions } \\
\hline (R63) & $\begin{array}{l}\mathrm{OH}+\mathrm{TOL}_{\rightarrow} \rightarrow 0.08 \mathrm{XO}_{2}+0.36 \mathrm{CRES}+0.44 \mathrm{HO}_{2} \\
+0.56 \mathrm{TO}_{2}\end{array}$ & $0.186 \mathrm{E}+06$ & $\mathrm{e}^{322 / \mathrm{T}}$ & $0.549 \mathrm{E}+06$ \\
\hline (R64) & $\begin{array}{l}\mathrm{TO}_{2}+\mathrm{NO} \rightarrow 0.08 \mathrm{XO}_{2}+0.36 \mathrm{CRES}+0.44 \mathrm{HO}_{2} \\
+0.56 \mathrm{TO}_{2}\end{array}$ & $0.720 \mathrm{E}+06$ & none & $0.720 \mathrm{E}+06$ \\
\hline (R65) & $\mathrm{TO}_{2} \rightarrow \mathrm{HO}_{2}+\mathrm{CRES}$ & $0.150 \mathrm{E}+05$ & none & $0.150 \mathrm{E}+05$ \\
\hline (R66) & $\begin{array}{l}\mathrm{OH}+\mathrm{CRES} \rightarrow 0.40 \mathrm{CRO}+0.60 \mathrm{XO}_{2}+0.60 \mathrm{HO}_{2} \\
+0.30 \mathrm{OPEN}\end{array}$ & $.0366 \mathrm{E}+07$ & none & $0.366 \mathrm{E}+07$ \\
\hline (R67) & $\mathrm{NO}_{3}+\mathrm{CRES} \rightarrow \mathrm{CRO}+\mathrm{HNO}_{3}$ & $0.195 \mathrm{E}+07$ & none & $0.195 \mathrm{E}+07$ \\
\hline (R68) & $\mathrm{CRO}+\mathrm{NO}_{2} \rightarrow$ & $0.120 \mathrm{E}+07$ & none & $0.120 \mathrm{E}+07$ \\
\hline (R69) & $\mathrm{OPEN}+\mathrm{hv} \rightarrow \mathrm{C}_{2} \mathrm{O}_{3}+\mathrm{CO}+\mathrm{HO}_{2}$ & radiation dependent & none & na \\
\hline (R70) & $\mathrm{OH}+\mathrm{OPEN} \rightarrow \mathrm{XO}_{2}+\mathrm{C}_{2} \mathrm{O}_{3}+2 \mathrm{HO}_{2}+2 \mathrm{CO}+\mathrm{FORM}$ & $0.264 \mathrm{E}+07$ & none & $0.264 \mathrm{E}+07$ \\
\hline (R71) & $\begin{array}{l}\mathrm{O}_{3}+\mathrm{OPEN} \rightarrow 0.03 \mathrm{ACET}+0.62 \mathrm{C}_{2} \mathrm{O}_{3}+0.70 \mathrm{FORM} \\
+0.03 \mathrm{XO}_{2}+0.69 \mathrm{CO}+0.08 \mathrm{OH}+0.76 \mathrm{HO}_{2} \\
+0.20 \mathrm{MGLY}\end{array}$ & $0.482 E+01$ & $e^{-500 / r}$ & $0.90 \mathrm{E}+00$ \\
\hline (R72) & $\begin{array}{l}\mathrm{OH}+\mathrm{XYL} \rightarrow 0.70 \mathrm{HO}_{2}+0.50 \mathrm{XO}_{2}+0.20 \mathrm{CRES}+0.80 \\
\mathrm{MGLY}+1.10 \mathrm{PAR}+0.30 \mathrm{TO}_{2}\end{array}$ & $0.147 \mathrm{E}+07$ & $e^{116 / \pi}$ & $0.217 \mathrm{E}+07$ \\
\hline
\end{tabular}




\begin{tabular}{|c|c|c|c|c|}
\hline $\begin{array}{l}\text { Reaction } \\
\text { No. }\end{array}$ & Reaction & $\begin{array}{l}\text { Pre-factor } \\
\mathrm{ppm}^{-\mathrm{n}} \mathrm{hr}^{-1}\end{array}$ & $\begin{array}{l}\text { Temperature } \\
\text { dependency }\end{array}$ & $\begin{array}{l}\text { Rate constant at } 298 \mathrm{~K} \\
\mathrm{ppm}^{-\mathrm{n}} \mathrm{hr}^{-1}\end{array}$ \\
\hline (R73) & $\mathrm{OH}+\mathrm{MGLY} \rightarrow \mathrm{XO}_{2}+\mathrm{C}_{2} \mathrm{O}_{3}$ & $0.156 \mathrm{E}+07$ & none & $0.156 \mathrm{E}+07$ \\
\hline (R74) & $\mathrm{MGLY}+\mathrm{hv}+\mathrm{C}_{2} \mathrm{O}_{3}+\mathrm{CO}+\mathrm{HO}_{2}$ & radiation dependent & none & na \\
\hline \multicolumn{5}{|c|}{ Isoprene Reactions } \\
\hline \multirow[t]{2}{*}{ (R75) } & $\begin{array}{l}\mathrm{O}+\mathrm{ISOP} \rightarrow 0.60 \mathrm{HO}_{2}+0.80 \mathrm{ACET}+0.55 \mathrm{OLE} \\
+0.50 \mathrm{XO}_{2}+0.50 \mathrm{CO}+0.45 \mathrm{ETH}+0.90 \mathrm{PAR}\end{array}$ & & & \\
\hline & & $0.162 \mathrm{E}+07$ & none & $0.162 \mathrm{E}+07$ \\
\hline \multirow[t]{2}{*}{ (R76) } & $\begin{array}{l}\mathrm{OH}+\mathrm{ISOP} \rightarrow \mathrm{FORM}+\mathrm{XO}_{2}+0.67 \mathrm{HO}_{2}+0.40 \mathrm{MGLY} \\
+0.20 \mathrm{C}_{2} \mathrm{O}_{3}+\mathrm{ETH}+0.20 \mathrm{ACET}+0.13 \mathrm{X}_{2} \mathrm{~N}\end{array}$ & & & \\
\hline & & $0.852 \mathrm{E}+07$ & none & $0.852 E+07$ \\
\hline \multirow[t]{2}{*}{ (R77) } & $\begin{array}{l}\mathrm{O}_{3}+\mathrm{ISOP} \rightarrow \mathrm{FORM}+0.40 \mathrm{ACET}+0.55 \mathrm{ETH}+0.20 \\
\mathrm{MGLY}+0.06 \mathrm{CO}+0.10 \mathrm{PAR}+0.44 \mathrm{HO}_{2}+0.10 \mathrm{OH}\end{array}$ & & & \\
\hline & & $0.108 \mathrm{E}+01$ & none & $0.108 \mathrm{E}+01$ \\
\hline (R78) & $\mathrm{NO}_{3}+\mathrm{ISOP} \rightarrow \mathrm{XO}_{2} \mathrm{~N}$ & $0.282 E+05$ & none & $0.282 \mathrm{E}+05$ \\
\hline \multicolumn{5}{|c|}{ Operator Reactions } \\
\hline (R79) & $\mathrm{XO}_{2}+\mathrm{NO} \rightarrow \mathrm{NO}_{2}$ & $0.7200 \mathrm{E}+06$ & none & $0.720 \mathrm{E}+06$ \\
\hline (R80) & $\mathrm{XO}_{2}+\mathrm{XO}_{2} \rightarrow$ & $0.153 \mathrm{E}+09$ & $e^{1300 / t}$ & $0.12 \mathrm{E}+06$ \\
\hline (R81) & $\mathrm{XO}_{2} \mathrm{~N}+\mathrm{NO} \rightarrow$ & $0.600 \mathrm{E}+05$ & none & $0.600 \mathrm{E}+05$ \\
\hline \multicolumn{5}{|c|}{ Sulfur Reactions } \\
\hline (R82) & $\mathrm{OH}+\mathrm{SO}_{2} \rightarrow \mathrm{SULF}$ & $0.389 \mathrm{E}+05$ & $\mathbf{e}^{1600 \pi}$ & $0.666 \mathrm{E}+05$ \\
\hline (R83) & $\mathrm{SO}_{2}+\mathrm{O}_{3} \rightarrow \mathrm{SULF}$ & $0.490 \mathrm{E}-02$ & none & $0.490 \mathrm{E}-02$ \\
\hline \multicolumn{5}{|c|}{ Alcohol Reactions } \\
\hline (R84) & $\mathrm{OH}+\mathrm{MEOH} \rightarrow \mathrm{FORM}+\mathrm{HO}_{2}$ & $0.960 \mathrm{E}+05$ & none & $0.960 \mathrm{E}+05$ \\
\hline (R85) & $\mathrm{OH}+\mathrm{ETOH} \rightarrow \mathrm{ACET}+\mathrm{HO}_{2}$ & $0.143 \mathrm{DE}+06$ & $e^{176 \pi}$ & $0.258 \mathrm{E}+06$ \\
\hline \multicolumn{5}{|c|}{ Null Reaction } \\
\hline (R86) & NR & $0.681 E+04$ & $e^{1300 / \mathrm{r}}$ & $0.534 \mathrm{E}+06$ \\
\hline \multicolumn{5}{|c|}{ Benzene Reaction } \\
\hline (R87) & $\mathrm{BENZ}+\mathrm{OH} \rightarrow \mathrm{OH}$ & $0.109 \mathrm{E}+06$ & none & $0.109 E+06$ \\
\hline $\begin{array}{l}\text { Urban Airshe } \\
\text { rransportatio }\end{array}$ & $\begin{array}{l}\text { deling of Air Quality Impacts of Alternative } \\
\text { el Use in Los Angeles and Atlanta }\end{array}$ & $3-9$ & & \\
\hline
\end{tabular}




\begin{tabular}{|c|c|c|c|c|}
\hline $\begin{array}{l}\text { Reaction } \\
\text { No. }\end{array}$ & Reaction & $\begin{array}{l}\text { Pre-factor } \\
\mathrm{ppm}^{-n} \mathrm{hr}^{-1}\end{array}$ & $\begin{array}{l}\text { Temperature } \\
\text { dependency }\end{array}$ & $\begin{array}{l}\text { Rate constant at } 298 \mathrm{~K} \\
\mathrm{ppm}^{-1} \mathrm{hr}^{-1}\end{array}$ \\
\hline \multicolumn{5}{|c|}{ Disaggregated Aldehyde Reactions } \\
\hline (R88) & $\mathrm{IOLE}+\mathrm{OH} \rightarrow 1.5 \mathrm{ACET}+0.5 \mathrm{HALD}+\mathrm{HO}_{2}+\mathrm{XO}_{2}$ & $0.566 \mathrm{E}+07$ & none & $0.566 \mathrm{E}+07$ \\
\hline (R89) & $\begin{array}{l}\text { IOLE }+\mathrm{O} \rightarrow 1.425 \mathrm{ACET}+0.475 \mathrm{HALD}+0.1 \mathrm{HO}_{2} \\
+0.1 \mathrm{XO}_{2}+0.1 \mathrm{CO}+0.1 \mathrm{PAR}\end{array}$ & $0.204 \mathrm{E}+07$ & none & $0.204 \mathrm{E}+07$ \\
\hline (R90) & $\begin{array}{l}\text { IOLE }+\mathrm{O}_{3} \rightarrow 0.75 \mathrm{ACET}+0.25 \mathrm{HALD}+0.2 \mathrm{OH} \\
+.25 \mathrm{CO}\end{array}$ & $0.186 \mathrm{E}+02$ & none & $0.186 \mathrm{E}+02$ \\
\hline (R91) & $\mathrm{IOLE}+\mathrm{NO}_{3} \rightarrow 1.5 \mathrm{ACET}+0.5 \mathrm{HALD}+\mathrm{NO}_{2}$ & $0.344 \mathrm{E}+05$ & none & $0.344 \mathrm{E}+05$ \\
\hline (R92) & $\mathrm{HALD}+\mathrm{OH} \rightarrow \mathrm{C}_{3} \mathrm{O}_{3}$ & $0.144 \mathrm{E}+07$ & none & $0.144 \mathrm{E}+07$ \\
\hline (R93) & $\mathrm{HALD}+\mathrm{h} \nu \rightarrow \mathrm{ACET}+2 \times \mathrm{HO}_{2}+\mathrm{CO}+\mathrm{XO}_{2}-\mathrm{PAR}$ & radiation dependent & none & na \\
\hline (R94) & $\mathrm{HALD}+\mathrm{O} \rightarrow \mathrm{OH}+\mathrm{C}_{3} \mathrm{O}_{3}+-\mathrm{PAR}$ & $0.382 \mathrm{E}+05$ & none & $0.382 \mathrm{E}+05$ \\
\hline (R95) & $\mathrm{HALD}+\mathrm{NO}_{3} \rightarrow \mathrm{C}_{3} \mathrm{O}_{3}+\mathrm{HNO}_{3}-\mathrm{PAR}$ & $0.242 \mathrm{E}+03$ & none & $0.242 \mathrm{E}+03$ \\
\hline (R96) & $\mathrm{C}_{3} \mathrm{O}_{3}+\mathrm{NO}_{2} \rightarrow \mathrm{HPAN}$ & $0.230 \mathrm{E}+06$ & $e^{-380 / \pi}$ & $0.643 \mathrm{E}+05$ \\
\hline (R97) & $\mathrm{HPAN} \rightarrow \mathrm{C}_{3} \mathrm{O}_{3}+\mathrm{NO}_{2}$ & $0.337 \mathrm{E}+21$ & $\mathrm{e}^{-14000 / \mathrm{T}}$ & $0.133 E+01$ \\
\hline (R98) & $\mathrm{C}_{3} \mathrm{O}_{3}+\mathrm{NO} \rightarrow \mathrm{NO}_{2}+\mathrm{ACET}+\mathrm{HO}_{2}+\mathrm{XO}_{2}$ & $0.310 \mathrm{E}+07$ & $e^{-180 / \pi}$ & $0.567 \mathrm{E}+07$ \\
\hline \multicolumn{5}{|c|}{ Toxic Compound Reactions } \\
\hline (R99) & $\mathrm{BUDI}+\mathrm{OH} \rightarrow \mathrm{OH}+\mathrm{ACRO}$ & $0.594 \mathrm{E}+07$ & none & $0.594 \mathrm{E}+07$ \\
\hline (R100) & BUDI $+\mathrm{O}_{3} \rightarrow \mathrm{O}_{3}+$ ACRO & $0.600 \mathrm{E}+00$ & none & $0.600 \mathrm{E}+00$ \\
\hline (R101) & $\mathrm{BUDI}+\mathrm{NO}_{3} \rightarrow \mathrm{NO}_{3}$ & $0.870 \mathrm{E}+04$ & none & $0.870 \mathrm{E}+04$ \\
\hline (R102) & $\mathrm{ACRO}+\mathrm{OH} \rightarrow \mathrm{OH}$ & $0.180 \mathrm{E}+07$ & none & $0.138 \mathrm{e}+07$ \\
\hline (R103) & $\mathrm{ACRO}+\mathrm{O}_{3} \rightarrow \mathrm{O}_{3}$ & $0.666 \mathrm{E}-01$ & none & $0.666 \mathrm{E}-01$ \\
\hline (R104) & $\mathrm{PRPA}+\mathrm{OH} \rightarrow \mathrm{XO}_{2}+\mathrm{HO}_{2}+\mathrm{AONE}$ & $0.108 \mathrm{E}+06$ & none & $0.108 \mathrm{E}+06$ \\
\hline (R105) & $\mathrm{AONE}+\mathrm{OH} \rightarrow \mathrm{C}_{2} \mathrm{O}_{3}+\mathrm{FORM}+\mathrm{XO}_{2}$ & $0.348 \mathrm{E}+05$ & none & $0.348 \mathrm{E}+05$ \\
\hline (R106) & $\mathrm{AONE}+\mathrm{hv} \rightarrow \mathrm{FORM}+\mathrm{XO}_{2}+\mathrm{C}_{2} \mathrm{O}_{3}$ & radiation dependent & none & na \\
\hline \multicolumn{5}{|c|}{ Radical Reactions } \\
\hline (R107) & $\mathrm{C}_{3} \mathrm{O}_{3}+\mathrm{C}_{3} \mathrm{O}_{3} \rightarrow 2 \mathrm{XO}_{2}+2 \mathrm{ACET}+2 \mathrm{HO}_{2}$ & $0.222 \mathrm{E}+06$ & none & $0.222 E+06$ \\
\hline
\end{tabular}




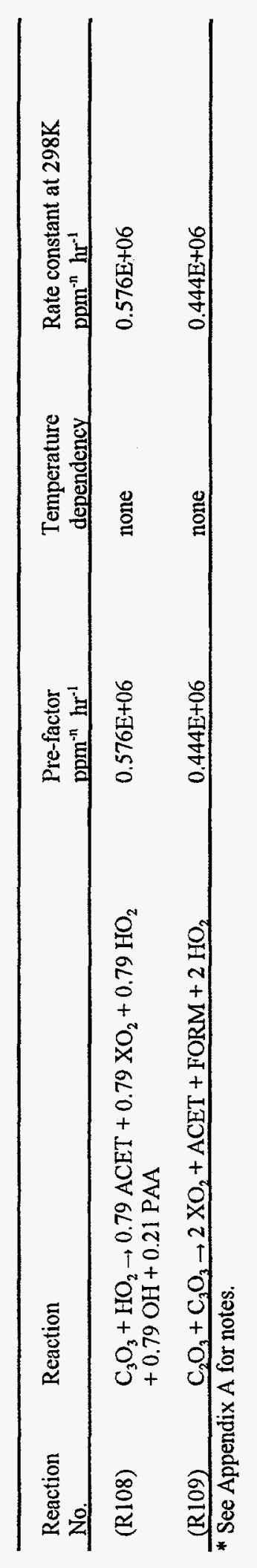

$\bar{m}$

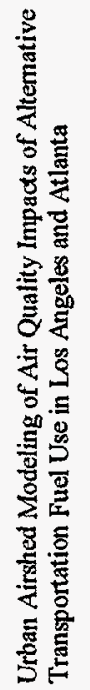


Table 3-3. linal Predicted Concentrations for the Major Nitrogen Species from the 6-Hour Daytime BOXCHEM Simulation CBM and TOXIC (units are ppm)

\begin{tabular}{ccc}
\hline Chemical Species & CBM Simulation & TOXIC Simulation \\
\hline $\mathrm{NO}$ & $6.5 \times 10^{-5}$ & $5.9 \times 10^{-5}$ \\
$\mathrm{NO}_{2}$ & $3.2 \times 10^{-3}$ & $2.9 \times 10^{-3}$ \\
$\mathrm{HNO}_{3}$ & 0.057 & 0.049 \\
$\mathrm{PAN}$ & 0.066 & 0.054 \\
$\mathrm{HPAN}$ & $\mathrm{NA}$ & 0.025 \\
\hline
\end{tabular}




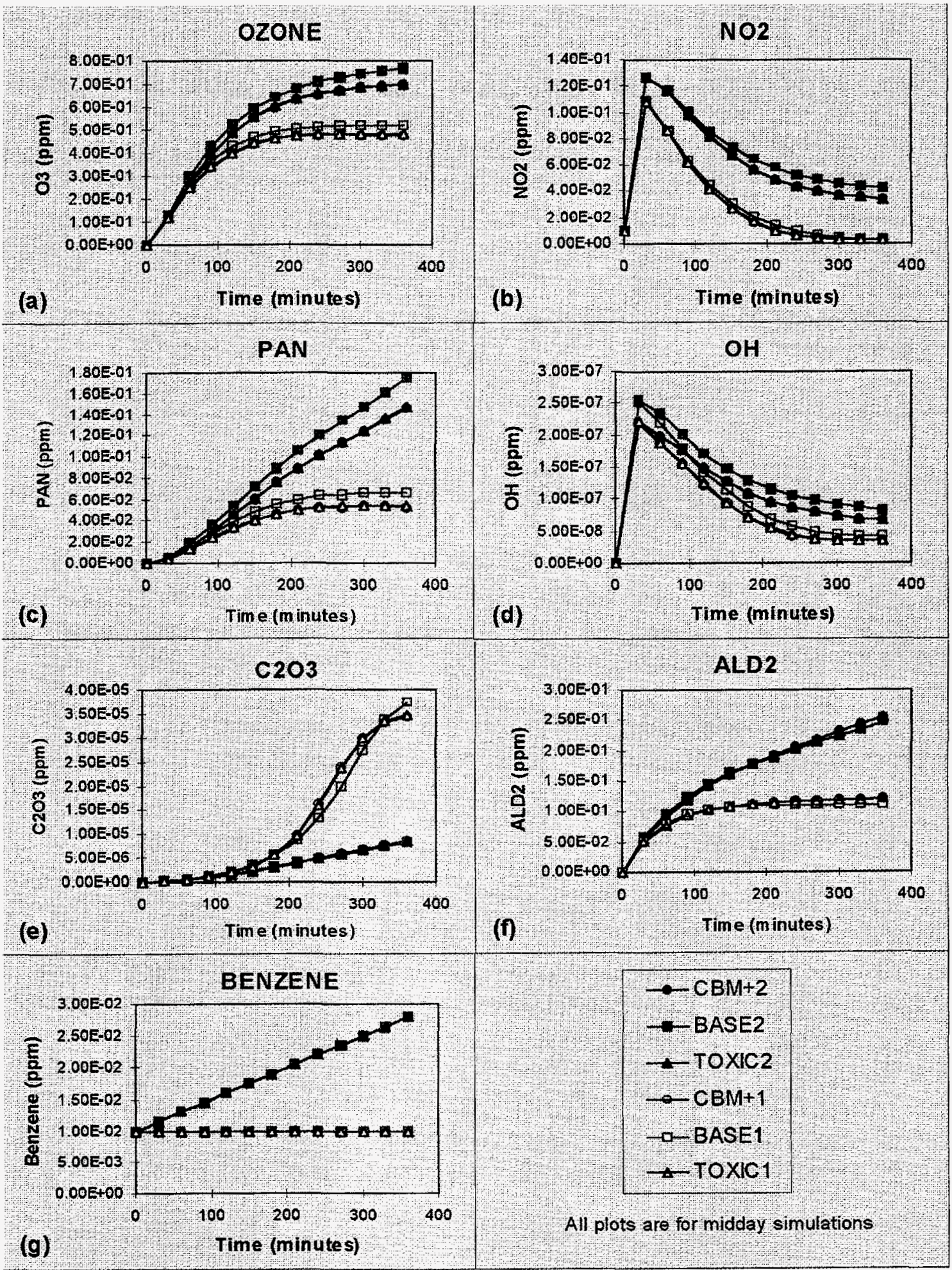

Figure 3.1. BOXCHEM comparison of CBM-IV, Base, and Toxics mechanisms for midday simulation 


\subsection{Model Setup and Quality Assurance for Los Angeles}

The modeling episode for the Los Angeles area chosen for this study is the 26-28 August 1987 episode developed by the SCAQMD. This section discusses the setup and testing performed for the Los Angeles modeling domain, before the alternative fuel scenarios were modeled. Two quality assurance model runs were made: one base case run (designated QA1) to duplicate the regulatory application, and a corresponding run (designated QA2) using toxics chemistry.

\subsection{Modeling Scenario and Sources of Model Inputs}

The model inputs used for Los Angeles are essentially those developed by SCAQMD for their 1994 SIP attainment modeling. The model inputs were reviewed in the modeling protocol (Appendix B). In the protocol, the meteorological conditions of the episode, the processes used to create the meteorological input files, and the quality of the SCAQMD files are discussed. For Los Angeles, the base case runs represent the 1987 emissions scenario. Table 4-1 summarizes the Los Angeles modeling domain, and how UAM-IV was applied to the domain. Table 4-2 summarizes the sources of the model input files. The meteorology inputs, including winds, surface temperatures, mixing heights, and domain-wide average scalars are all from the SCAQMD modeling files. The only exception was a minor correction in the temperature gradients appearing in the UAM-IV METSCALARS file.

Table 4-1. A Summary of Los Angeles Modeling Domain Characteristics

\begin{tabular}{lc}
\hline \multicolumn{1}{c}{ Model Domain Parameter } & Numerical Values Used \\
\hline $\begin{array}{l}\text { Universal Transverse Mercator (UTM) zone and } \\
\text { origin }\end{array}$ & Zone 12 at $275 \mathrm{~km} \mathrm{E,3670} \mathrm{km} \mathrm{N}$ \\
Number of cells in easting and northing & 65 cells by 36 cells \\
Size of grid cells in the horizontal & $5 \times 5 \mathrm{~km}$ \\
Number of model layers & 5 \\
Number of layers below diffusion break & 2 \\
Number of layers above diffusion break & 3 \\
Region top & $2,000 \mathrm{~m}$ \\
Minimum layer thickness below diffusion break & $25 \mathrm{~m}$ \\
Minimum layer thickness above diffusion break & $150 \mathrm{~m}$ \\
\hline
\end{tabular}


Table 4-2. Surrmary of Input Data Sources for the Los Angeles Episode

\begin{tabular}{ll}
\hline \multicolumn{1}{c}{ Modeling criteria } & \multicolumn{1}{c}{ UAM } \\
\hline Modeling period selected & $26-28$ August 1987 \\
Modeling domain & Los Angeles SCAQMD modeling domain used for 1994 AOMP \\
Meteorological fields & SCAQMD files generated using the hybrid Systems \\
& Applications International Mesoscale Model (SAIMM)/objective \\
analysis approach & Use SCAQMD files developed for the base year (1987) \\
simulation. Toxics are added based on observations & \\
Use SCAOMD files developed for the base year simulation. & Toxics are added based on observations \\
Initial conditions & Base-year (1987) emissions are from SCAQMD. Future-year \\
Point-source emissions & 2007 emissions estimated from linear interpolation of South \\
Coast Association of Governments (SCAG) estimated 2000 \\
and 2010 projection factors and SCAOMD 1990 point source \\
inventory. \\
Midrange of base-year day'-specific emissions using the \\
Biogenic Emission Information System (BEIS) with inputs \\
supplied by SCAOMD \\
Base year (1987) emissions are from SCAOMD. For 2007, \\
EMFAC7F mobile emissions. Stationary source emissions \\
estimated as described above for point sources.
\end{tabular}

Before running the model, the point source preprocessor was applied to create a file of elevated point source emissions. The SCAQMD used a version of UAM-IV with the PAN chemistry corrections, but the code was not an official $6.2 \mathrm{X}$ version. Version 6.21 was used throughout this study. One other small difference is that the MAXITElR parameter in the CHEM2B subroutine was set to 50 to prevent the model run from crashing on 26 Augu:t, as per tip \#9 from the UAM USERTIPS.TXT file available from EPA OAQPS on the SCRAM electronic bulletin board.

\subsection{Modification of Initial Input Data Sets for Toxic Compounds}

For the toxics chemistry simulation, explicit breakout of the ALD2 surrogate into ACET and HALD (described in Section 3) requires modifications to emissions and initial and boundary concentration files. A processor was developed that performed the respeciation using mass conservation of carbon. The following modifications were rnade to the AIRQUALITY, BOUNDARY, and TOPCONC files used by UAM-IV:

- Ambient ACET concentrations were set equal to 0.65 of the original ALD2 concentrations.

- HALD concentrations were set equal to 0.23 of ALD2 concentrations.

- $\quad$ BENZ concentrations were set equal to 0.50 of TOL concentrations. 
BUDI concentrations were set equal to 0.30 of OLE concentrations.

For the toxics comparison simulation, BENZ emissions were set to one quarter of TOL emissions and BUDI emissions were set equal to 0.20 of OLE emissions closer to the toxic emission totals given in Harley and Cass (1994) and

To determine whether initial concentrations of toxics were appropriate, the initial mass of each compound was compared with the predicted mass at the end of the second day. Results of this mass balance analysis are given in Table 4-3. The results show that the initial mass for each species is not drastically different from the final mass loadings, suggesting that the initial conditions are reasonable. The top and side boundary conditions were evaluated by reviewing the cumulative fluxes of material over the modeling period. The FORM fluxes that were specified by SCAQMD were not modified. However, the mass loading suggests that boundary fluxes are competing with the internal processes such as the chemistry. The loss of ACET through advection suggests that boundary concentrations are generally low enough that emitted and chemically produced ACET is being exported from the domain. BENZ reacts slowly and so inappropriate boundary concentrations would show up in the flux budget. However, we can see that the emissions outstrip the net export of BENZ by more than a factor of two. BUDI is destroyed rather rapidly . The boundary fluxes suggest that BUDI boundary concentrationsmay be too high. Most of the BUDI mas s is localized near the inflow boundaries.

Table 4-3. A Summary of Major Sources and Sinks of the Toxic

Chemicals in the Los Angeles Modeling Domain for the Base Year (1987)

(units are tons $\left[\mathrm{CH}_{4}\right.$ equivalent mass])

\begin{tabular}{cccccc}
\hline Specie & Emission & Advection & Chemistry & Initial mass & Final mass \\
\hline FORM & 34 & 474 & -580 & 425 & 344 \\
ACET & 75 & -130 & 91 & 227 & 268 \\
BENZ & 114 & -41 & -5 & 278 & 346 \\
BUDI & 34 & 101 & -137 & 6 & 4 \\
\hline
\end{tabular}

\subsection{Evaluation of Base Case Simulation without Air Toxics}

The initial simulation was performed using the UAM-IV inputs as they were received from SCAQMD. (One exception is the use of corrected temperature gradients for QA1, as described in Section 3 and in the protocol.) This simulation, denoted QA1, was for the base year (1987). The SCAQMD did not supply a model output hourly averaged concentration file for direct verification. Therefore, verification was accomplished using information from SCAQMD's final report (SCAQMD 1994). The daily maximum 1hour average $\mathrm{O}_{3}$ concentration patterns from both runs for 27 August are compared in Figure 4-1. ${ }^{1}$ The maximum 1-hour $\mathrm{O}_{3}$ concentration predicted by SCAQMD was $160.9 \mathrm{ppb}$, while the maximum predicted in QA1 is $160.3 \mathrm{ppb}$. Differences of up to $1 \mathrm{ppb}$ are commonly encountered in photochemical modeling when the identical simulation is run on different computer platforms. The predicted spatial patterns match closely, particularly for areas above $120 \mathrm{ppb}$.

\footnotetext{
${ }^{1}$ Figures in this section have been placed together following the text.
} 
The daily maximum 1-hour average surface $\mathrm{O}_{3}$ concentration pattern for 28 August is shown in Figure 4-2, which again shows that the highest concentrations occur in the same locations for both runs. The maximum, which occurs in Riverside County, is $190.5 \mathrm{ppb}$ for the SCAQMD simulation and is $188.9 \mathrm{ppb}$ for the QA1 simulation, a difference of $1.6 \mathrm{ppb}$. This difference is slightly larger than the $1 \mathrm{ppb}$ target identified in the protocol. This small difference is not surprising, however, particularly since the temperature gradient correcticns represent a change in inputs between the two runs.

Figure 4-3 illustrates the time series of hourly ozone predictions at two monitoring sites, Azusa and Norco, along with the observed ozone concentrations. For QA1, the predictions represent grid cell average concentrations. We do not know what procedure was used to determine the SCAQMD predictions at monitoring sites. Close agreenent is seen between the QA1 and SCAQMD time series. Substantial model under-prediction is evident at both sites, and is most extreme for 28 August at Azusa.

\subsection{Comparison of Base: Year with and without Toxic: Compound Chemistry}

The toxics QA simulation is denoted as QA2. Model inputs are the same as QA1, except that the inputs for the aldehydes and IOLE have been converted in the initial, boundary, and emissions files as described above in Section 4.2. Results fir QA1 and QA2 were compared, first in terms of predicted concentrations, and then based on mass budgets. Some differences in the $\mathrm{O}_{3}$ and aldehyde concentrations are expected, as described in Section 2. The disaggregated toxics chemistry tends to produce less $\mathrm{O}_{3}$ than the original CB-IV chemistry as noted earlier in Section 3.

The maximum daily 1-hour surface $\mathrm{O}_{3}$ concentration patterns for QA1 and QA2 are presented in Figures 4-4 and 4-5. The maximum concentrations for the toxics simulation are lower than for QA1. Differences between QA1 and QA2 are slightly greater on 28 August. The only place where there are higher predicted $\mathrm{O}_{3}$ concentrations for QA2 is over the ocean. The spatial pattern of daily maxima and the locations of predicted peaks are nearly identical for QA1 and QA2.

The differences in the maximum daily $\mathrm{O}_{3}$ concentrations from the QA1 and QA2 simulations are shown in Figures 4-6 and 4-7 for 27 and 28 August, respectively. On 27 August, the difference plot indicates that reductions in $\mathrm{O}_{3}$ in the 10 to $20 \mathrm{ppb}$ range occurred over a broad area. The maximum difference is $19 \mathrm{ppb}$, slightly more than $10 \%$ of the peak predicted concentration. Differences in individual grid cells can be larger than the difference between domain-maximum concentrations. For 27 August, the predicted QA2 domain maximum, $148.7 \mathrm{ppb}$, is only $11.6 \mathrm{ppb}$ lower the maximum of $160.3 \mathrm{ppb}$ for QA1, as seen in Figure 4-4. On 28 August, the concentration differences increase, with a maximum difference of 42.3 $\mathrm{ppb}$. This difference is much larger than the $13.1 \mathrm{ppb}$ difference between domain maximum values. In a region with steep gradients in predicted concentrations, a shift of one or two grid cells in the peak location between QA1 and QA2 can produce these large differences. The time series plots in Figures 4-3 show the time series of $\mathrm{O}_{3}$ at A.zusa and Norco for both the QA1 and the QA2 simulations. The largest differences appear to occur at the time when the maximum $\mathrm{O}_{3}$ is predicted.

The daily maximum fields of oxides of nitrogen $\left(\mathrm{NO}_{x}\right)$ and VOC for QA1 and QA2 were also plotted and compared. The daily maximum! 1-hour average surface VOC concentrations for 28 August are shown in Figure 4-8. The concentration field shows very little difference in the maximum predicted VOC concentrations. The peak concentrations differ by only $1 \mathrm{ppb}$. Figure 4-9 displays the daily maximum 1-hour average $\mathrm{NO}_{\mathrm{x}}$ concentrations. Visually, there is no difference between the QA1 and the QA2 fields . The maximum difference is less than $2 \mathrm{ppb}$. The daily maximum FORM concentration field was plotted for both QA1 and QA2. The results are shown in Figure 4-10. The QA1 simulation predicts higher peak FORM concentrations (18.2 vs. $15.8 \mathrm{ppb}$ ). 


\subsection{Mass Budget Analysis}

A mass budget analysis was conducted to provide further comparison of the QA1 and QA2 simulations. The cumulative production and destruction of selected species for 27-28 August are presented in Table 4-4. This table indicates that the chemistry of ACET has been significantly altered by the disaggregation of the CBM-IV chemical scheme. There is a net destruction of ALD2 in the original scheme (using the FORM photolysis rates) but there is a net production of ACET in the toxics chemistry case. The difference is partly due to the altered ACET destruction by photolysis. Mass destruction of such species as OLE and ETH is relatively unchanged.

Table 4-4. A Summary of the Chemical Production of $\mathrm{O}_{3}$ and Other Chemicals over the Period 27-28 August in the Los Angeles Modeling Domain (units are tons)

\begin{tabular}{ccc}
\hline Chemical Specie & $\begin{array}{c}\text { Base Run } \\
\text { (QA1) }\end{array}$ & $\begin{array}{c}\text { Toxics Chemistry Run } \\
\text { (QA2) }\end{array}$ \\
\hline O3 & 17074 & 14672 \\
OLE & -478 & -478 \\
TOL & -667 & -663 \\
XYL & -603 & -602 \\
FORM & -546 & -580 \\
ALD2/ACET & -68 (ALD2) & 91 (ACET) \\
ETH & -501 & -498 \\
HPAN & NA & 24 \\
PAN & 520 & 492 \\
HNO3 & 4372 & 4338 \\
\hline
\end{tabular}

Table 4-4 indicates that the chemistry of CBM-IV organic species that are not affected by the change in the chemical mechanism seems to be relatively unchanged as well. However, minor perturbations (5\% or less over two days) do seem to be present in the $\mathrm{NO}_{\mathrm{x}}$ chemistry for the CBM-IV toxics scheme. The concentration of HPAN varies over several orders of magnitude between midnight and noon with HPAN being formed by radical reactions during the day and decomposition resulting in a rapid HPAN destruction at night. Net production of HPAN for a midnight to midnight simulation is realtively small as shown in Table 4-4, unlike the BOXCHEM which covers an afternoon period. The impact of adding HPAN on night-time $\mathrm{No}_{x}$ is small since $\mathrm{NO}_{2}$ lost during the day is returned at night as a result of decompostion. The reduction in ozone production $(-14 \%)$ is due to day-time sequestering of $\mathrm{NO}_{\mathrm{x}}$ by HPAN and by a slowing of aldehyde chemistry production of $\mathrm{XO}_{2}$ radical which mediates the $\mathrm{NO}$ to $\mathrm{NO}_{2}$ conversion. 

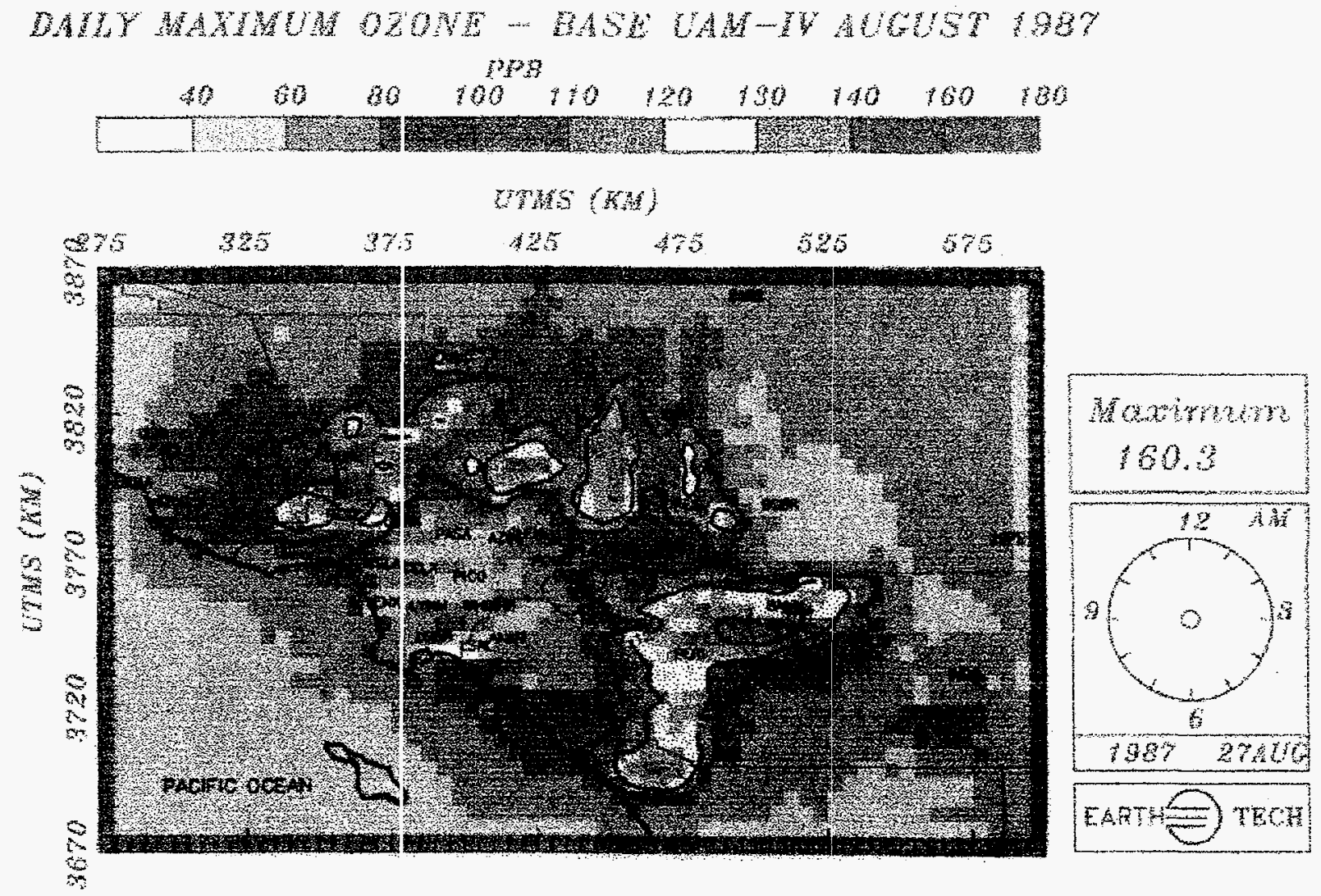

Figure 4-1. Comparison of daily maximum 1-hour surface $\mathrm{O}_{3}$ concentrations for 27 August for SCAQMD simulation (isopleths in pphm) and QA1 simulation (tiles in ppb). 

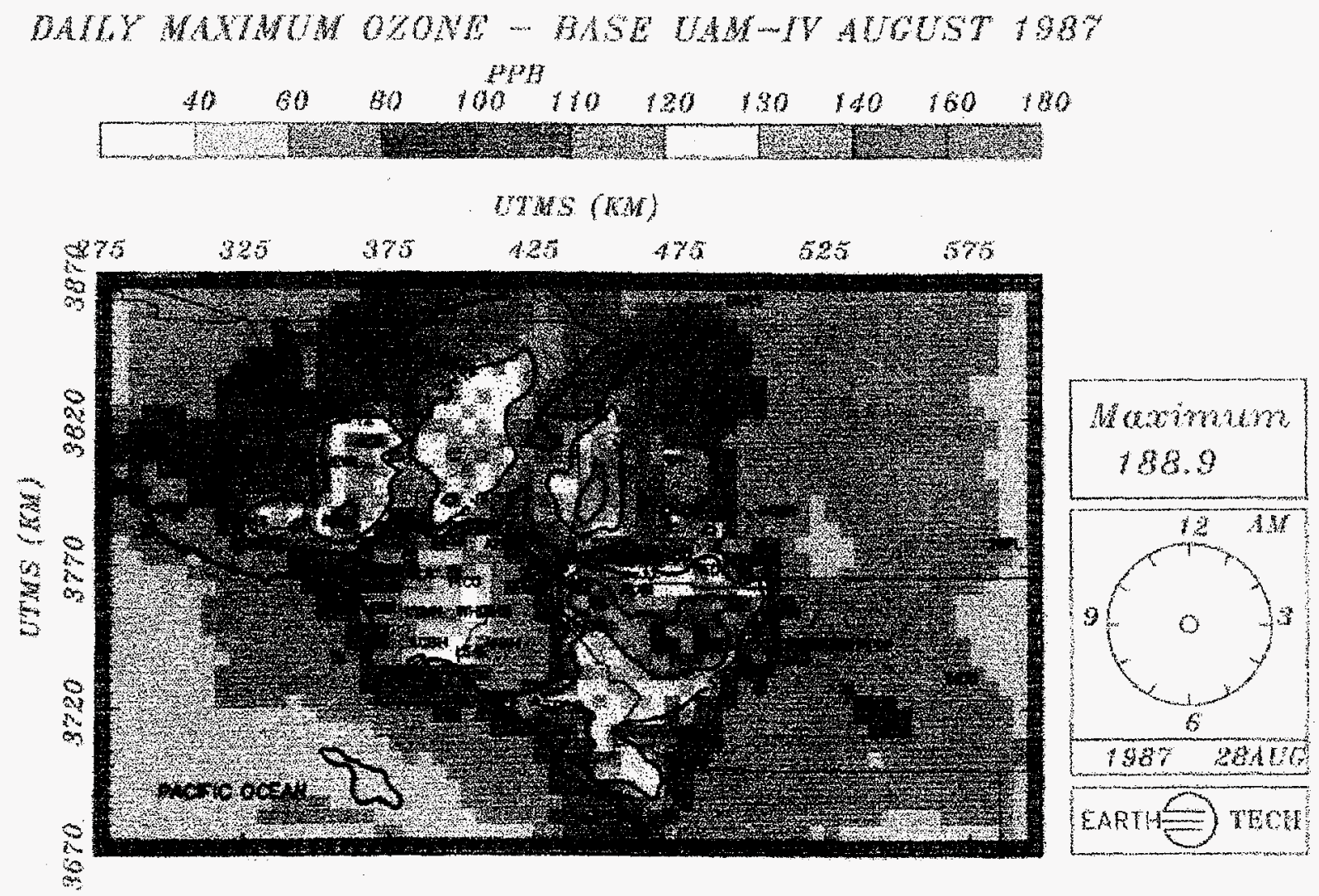

Figure 4-2. Comparison of daily maximum 1-hour surface $\mathrm{O}_{3}$ concentrations for 28 August for SCAOMD simulation (isopleths in pphm) and QA1 simulation (tiles in ppb). 


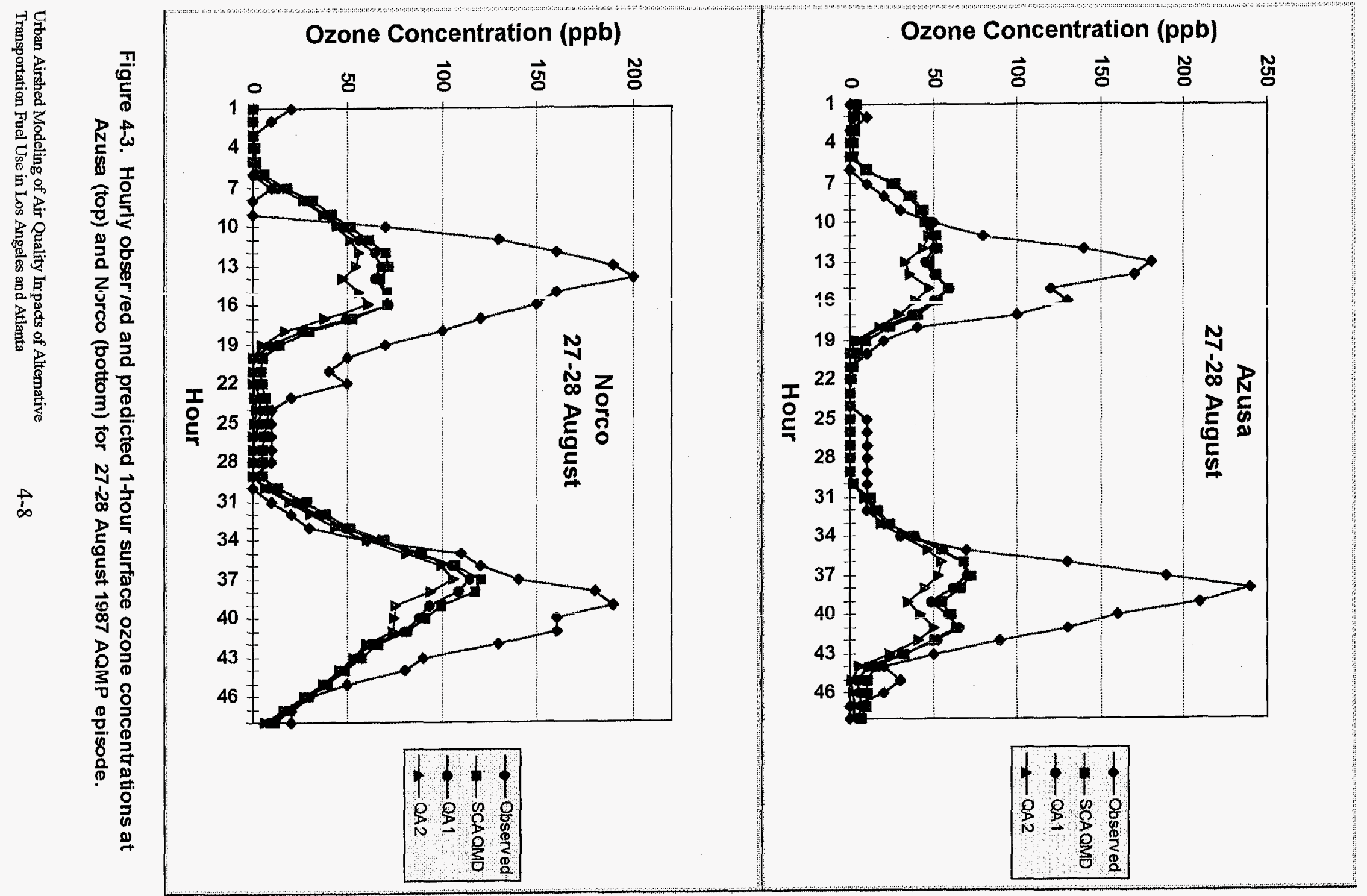




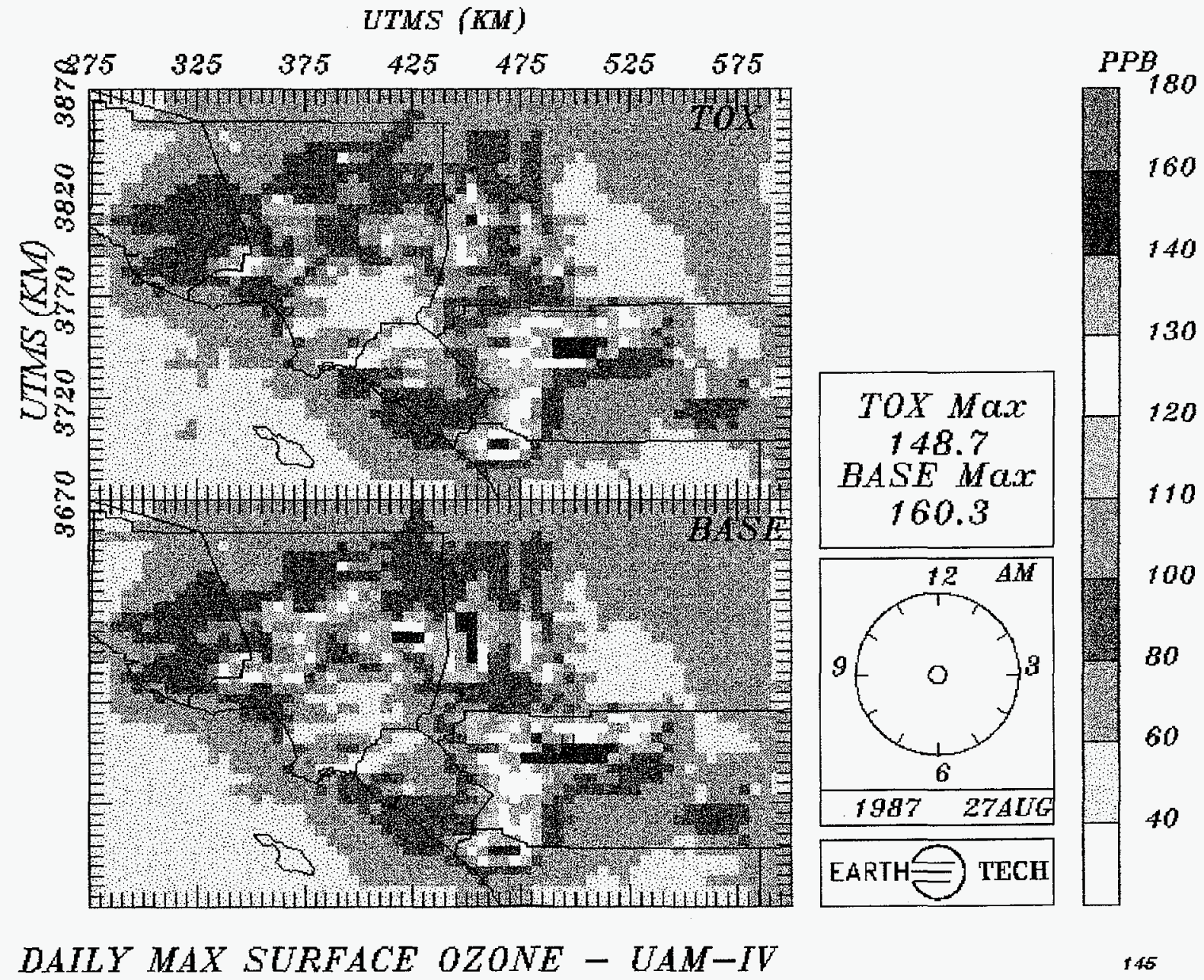

Figure 4-4. Daily maximum 1-hour surface $\mathrm{O}_{3}$ concentrations for Los Angeles for 27 August for QA1 (Base) and QA2 (Air Toxics) QA simulations. 

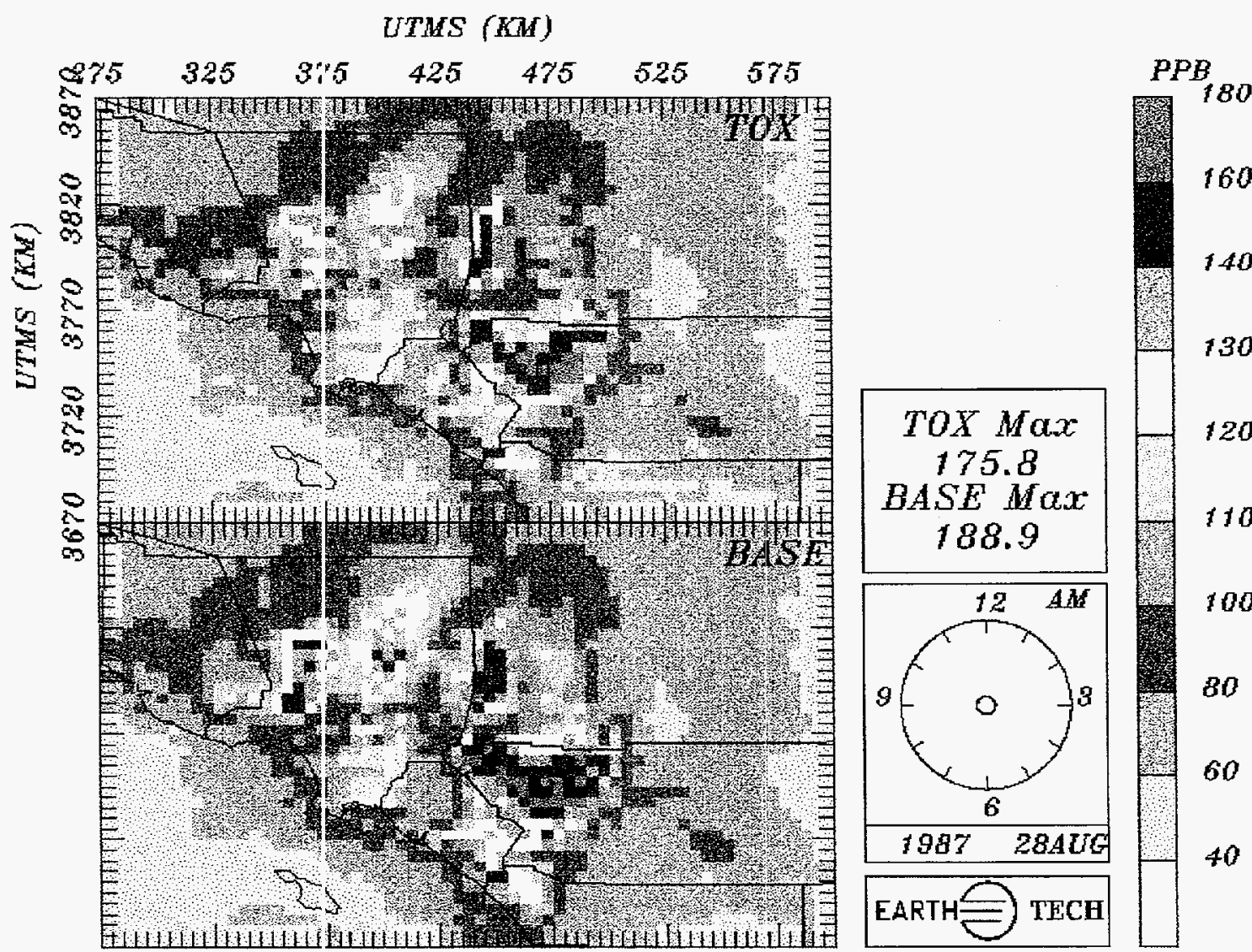

DAILY MAX SURFACE OZONE - UAM-IV

145

Figure 4-5. Daily maximuln 1-hour surface $\mathrm{O}_{3}$ concentrations for Los Angeles for 28 August for QA1 (Base) and QA2 (Air Toxics) QA simulations. 


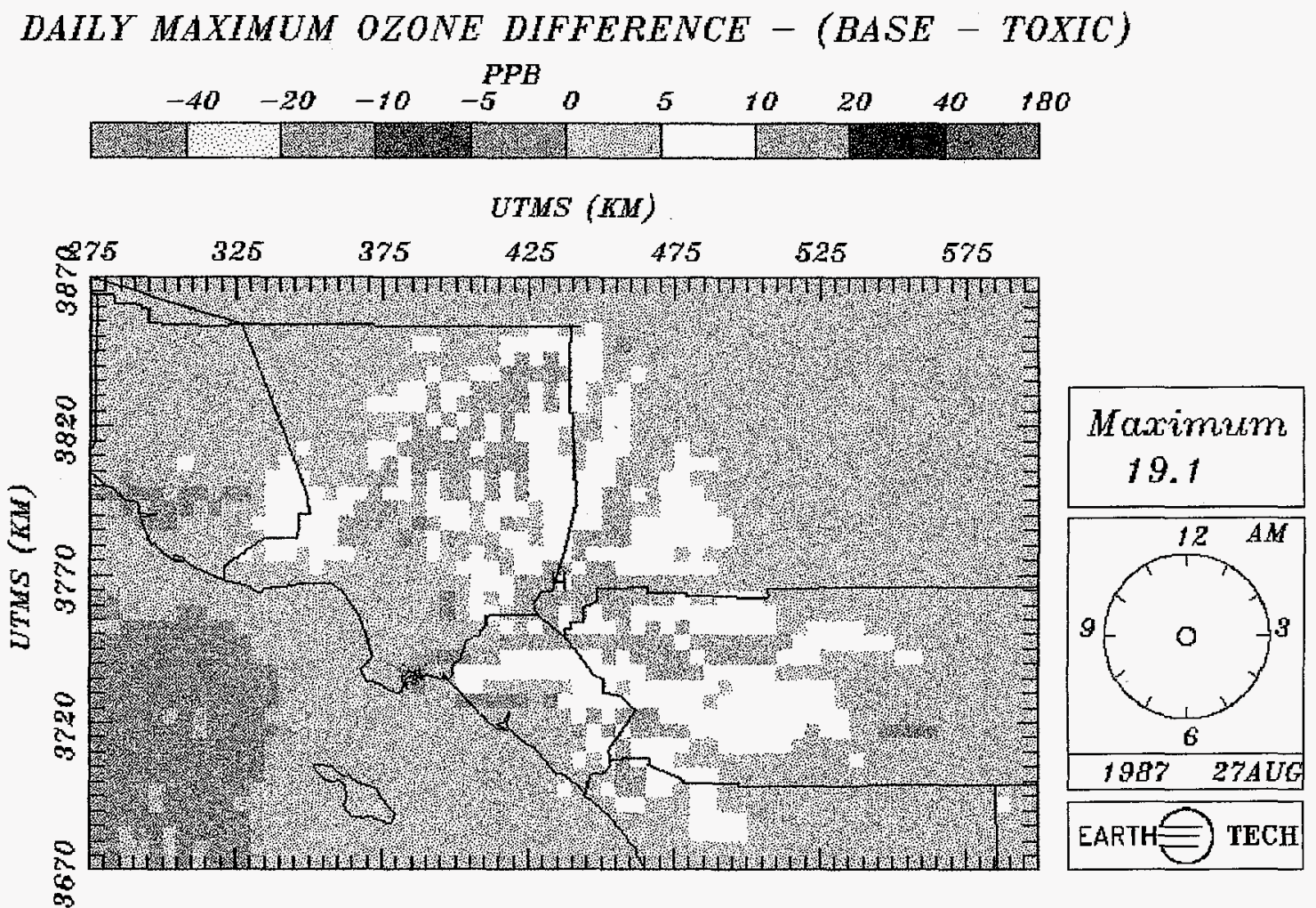

Figure 4-6. Difference in daily maximum 1-hour surface $\mathrm{O}_{3}$ concentrations for Los Angeles for 27 August for QA1 (Base) minus QA2 (Air Toxics) QA simulations. 
DALLY MAXIMUM OZONE DIFFERENCE - (BASE - TOXIC)

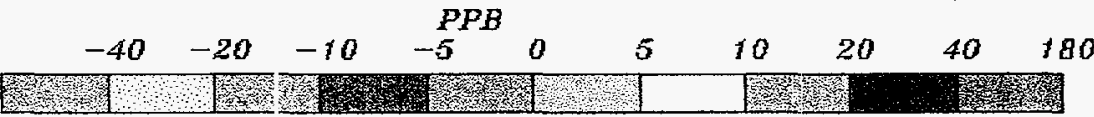

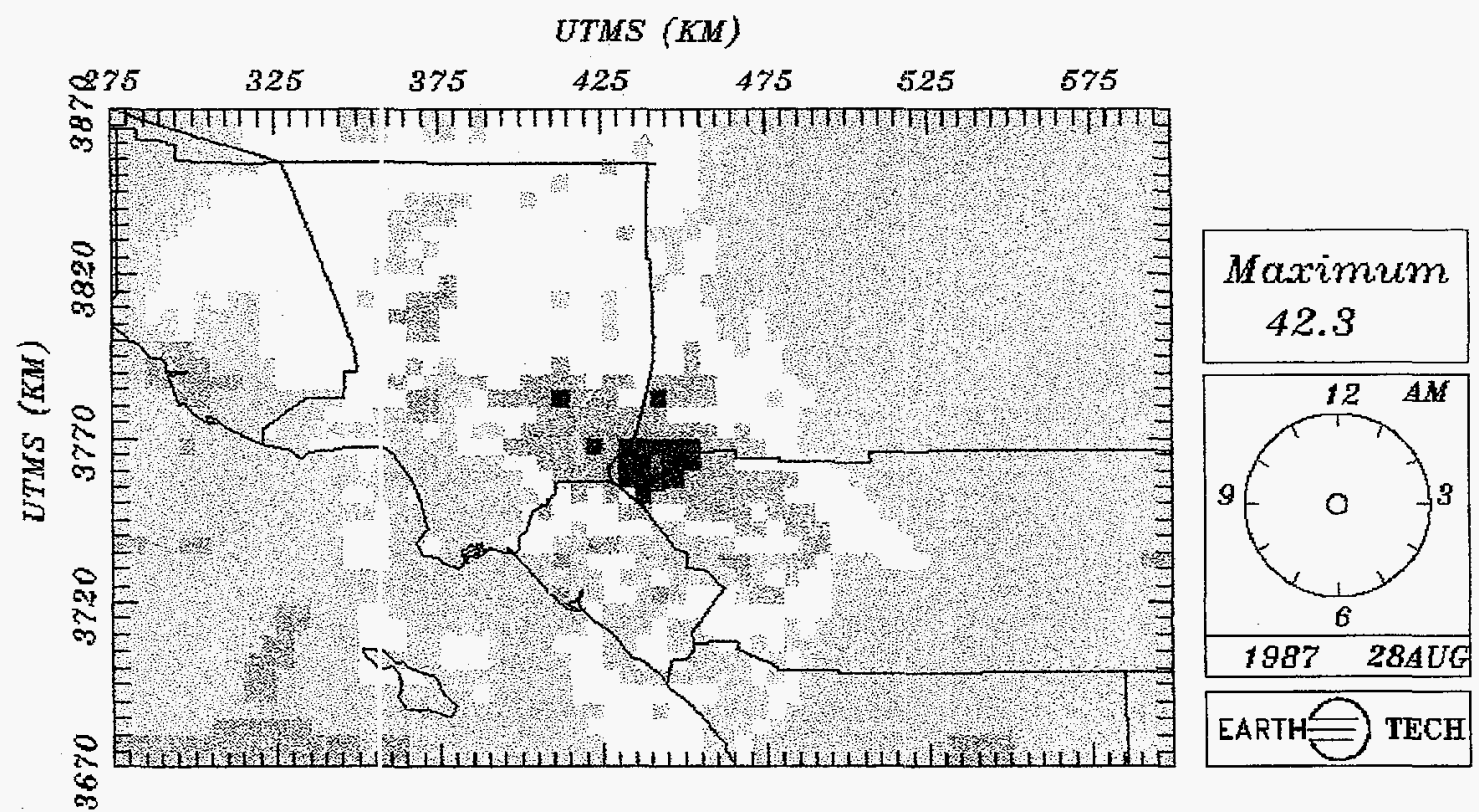

Figure 4-7. Difference in dialy maximum 1-hour surface $\mathrm{O}_{3}$ concentrations for Los Angeles for 28 August for QA.1 (Base) minus QA2 (Air Toxics) QA simulations. 


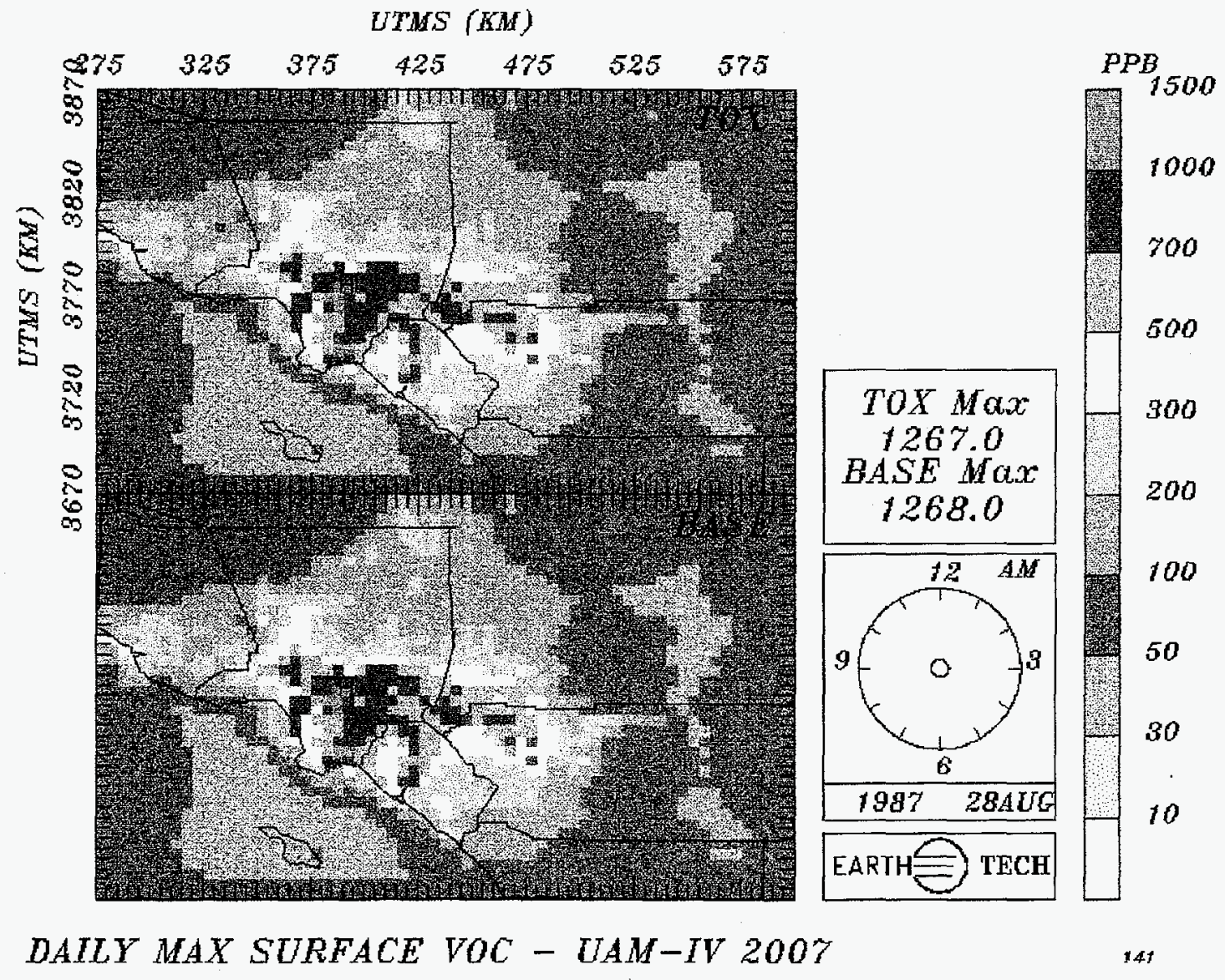

Figure 4-8. Daily maximum 1-hour surface VOC concentrations for Los Angeles for 28 August for QA1 (Base) and QA2 (Air Toxics) QA simulations. 


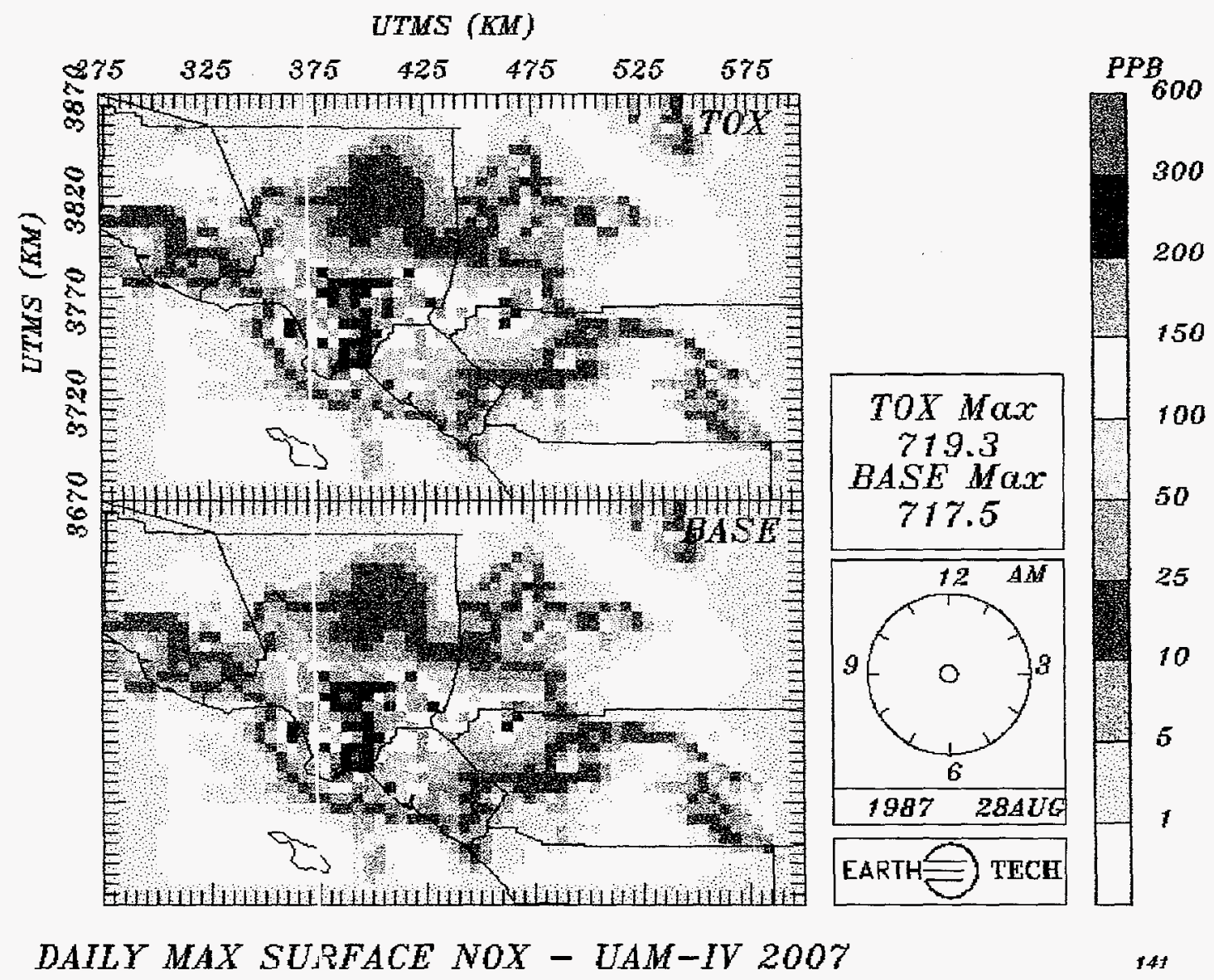

Figure 4-9. Daily maximuin 1-hour surface NO concentrations for Los Angeles for 28 August for QA1 (Base) and QA2 (Air Toxics) QA simulations. 


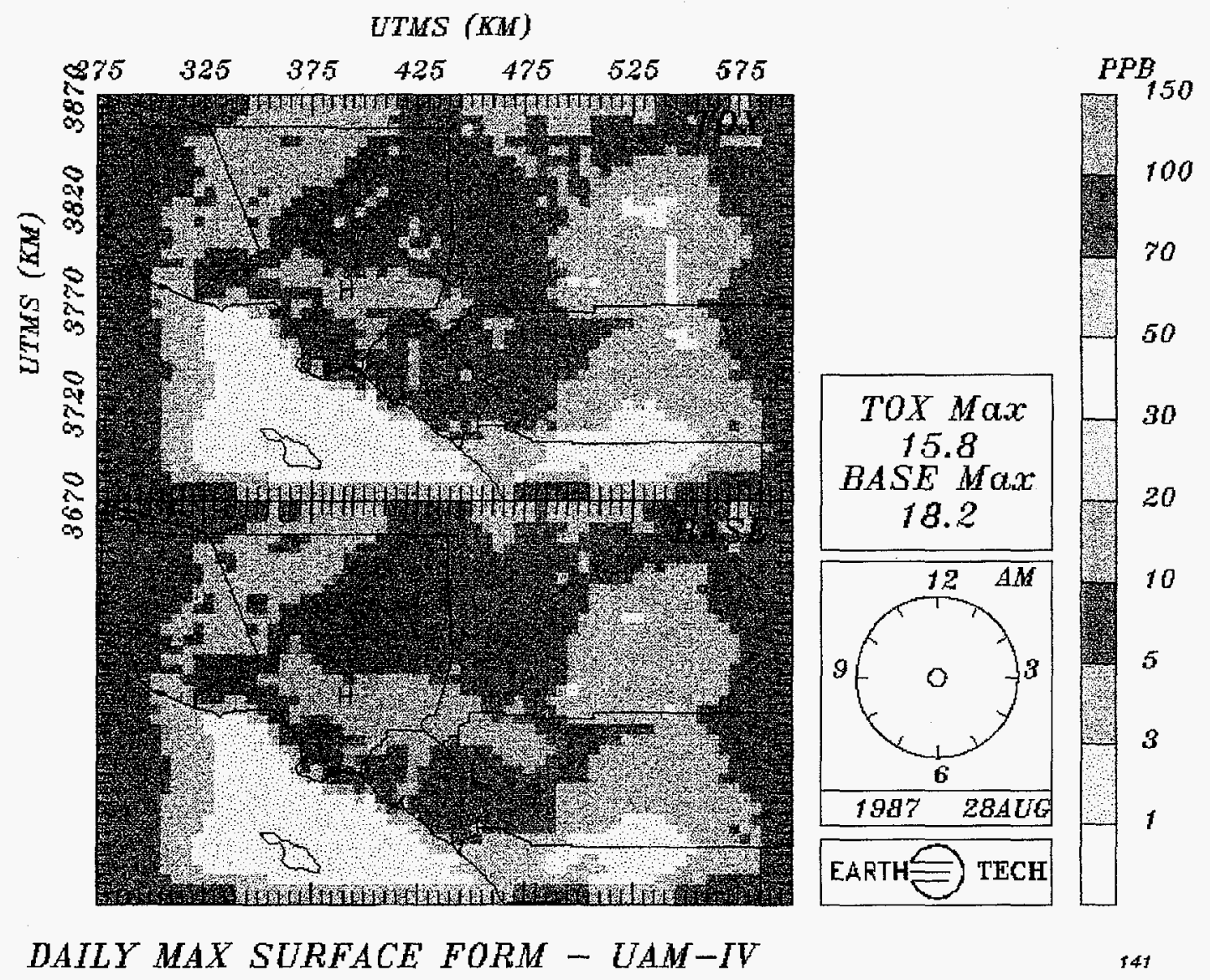

Figure 4-10. Daily maximum 1-hour surface FORM concentrations for Los Angeles for 28 August for QA1 (Base) and QA2 (Air Toxics) QA simulations. 


\subsection{Model Setup and Quality Assurance for Atlanta}

The modeling episode for the Atlanta area chosen for this study was the 29-31 July 1987 episode developed by the Georgia DNR for their 1994 SIP revision. This section discusses the setup and testing performed for the Atlanta modeling domain. Two QA model runs were made: one base run to duplicate the regulatory application, and a corresponding run with toxics chemistry. For the Atlanta episode, the base run represents a 1999 emissions scenario provided by Georgia DNR.

\subsection{Modeling Scenario and Sources of Model Inputs}

The model inputs used for Atlanta are essentially those developed by the DNR for their 1994 SIP modeling. The model inputs were reviewed in the modeling protocol (Appendix B). In the protocol, the meteorological conditions of the episode, the processes used to create the meteorological input files, and the quality of the DNR files are discussed. Table 5-1 summarizes the modeling domain and how UAM-IV was applied to the domain. Table 5-2 summarizes the sources of the model input files.

Modeling was conducted using the DNR meteorology. The winds, surface temperatures, mixing heights, and the meteorological domain-wide average scalars were used as received from the DNR. In changing from the UAM-IV with standard CBM-IV chemistry to the toxics version described in Section 3, it was necessary to change the chemical speciation in the emissions files, the initial condition files, and the boundary condition files.

Table 5-1. A Summary of Atlanta Modeling Domain Characteristics

\begin{tabular}{lc}
\hline \multicolumn{1}{c}{ Model Domain Parameter } & Numerical Values Used \\
\hline UTM zone and origin & Zone 16 at $660 \mathrm{~km} \mathrm{E}, 3665 \mathrm{~km} \mathrm{~N}$ \\
Number of cells in easting and northing & 40 cells by 40 cells \\
Size of grid cells in the horizontal & $4 \times 4 \mathrm{~km}$ \\
Number of model layers & 5 \\
Number of layers below diffusion break & 2 \\
Number of layers above diffusion break & 3 \\
Region top & $2,200 \mathrm{~m}$ \\
Minimum layer thickness below diffusion break & $25 \mathrm{~m}$ \\
Minimum layer thickness above diffusion break & $150 \mathrm{~m}$ \\
\hline
\end{tabular}


Table 5-2. Summary of Input Data Sources for the Atlanta Episode

\begin{tabular}{ll}
\hline \multicolumn{1}{c}{ Modeling criteria } & \multicolumn{1}{c}{ UAM } \\
\hline Modeling period selected & $29-31$ July 1987. \\
Modeling domain & Atlanta domain used for 1994 SIP modeling by Georgia DNR. \\
Meteorological fields & $\begin{array}{l}\text { Model inputs supplied by DNR - meteorological parameters developed by } \\
\text { Systems Applications International (SAI) from the SAI Mesoscale Model } \\
\text { (SAIMM). }\end{array}$ \\
Boundary conditions & $\begin{array}{l}\text { Are set to 1999 DNR values. Toxics are treated in the same manner as } \\
\text { for Los Angeles }\end{array}$ \\
Initial conditions & $\begin{array}{l}\text { Initial conditions on 29 July developed by DNR for 1999. Modifications } \\
\text { for toxics as for Los Angeles. }\end{array}$ \\
Point source emissions & $\begin{array}{l}\text { For base run, used 1999 emissions obtained from DNR. For 2007 } \\
\text { scenarios, point source emissions projected from state 1990 inventory to }\end{array}$ \\
$\begin{array}{l}2007 \text { using BEA growth factors and NO } \\
\text { technology (RACT) and VOC reasonable further progress (RFP) } \\
\text { requirements. }\end{array}$ \\
Same day-specific BEIS biogenic emissions as used by DNR. \\
Biogenic emissions \\
Surface emissions
\end{tabular}

Prior to exercising the model, the point source preprocessor was exercised to create a file of elevated point source emissions. For simulations with no toxics (QA1), the UAM-IV version 6.21 was used.

\subsection{Modification of Initial Input Data Sets for Toxic Compounds}

The explicit breakout of ALD2 into acetaldehyde (ACET) and HALD requires modifications to emissions and initial and boundary concentration files. A processor was developed that performed the respeciation using mass conservation of carbon. The fol owing modifications were made to the AIRQUALITY, BOUNDARY, and TOPCONC files used by UAM-IV:

- $\quad$ ACET concentrations wire set equal to 0.65 of the original ALD2 concentrations.

- HALD concentrations were set equal to 0.23 of ALD2 concentrations.

- BENZ concentrations were set equal to 0.50 of the prevailing TOL concentrations.

- BUDI concentrations were set equal to 0.30 of OLE concentrations. 
For the toxics comparison simulation, BENZ emissions were set to 0.30 of TOL emissions and BUDI emissions were set equal to 0.50 of the FORM emissions close to the toxic emission budget given in Harley and Cass (1994).

To determine whether initial concentrations of toxics were appropriate, the initial mass of each compound was compared with the predicted mass at the end of the second day. The results in Table 5-3 show that, with the exception of BENZ, the initial mass of each species is not very different from the final mass loading, suggesting that the initial conditions are reasonable. The top and side boundary conditions were examined via the cumulative fluxes of material over the modeling period. The FORM fluxes that were specified by the DNR were not modified. However, the mass loading suggests that boundary fluxes are competing with the internal processes such as the chemistry. The emissions of ACET approximately balance losses by chemistry and advective export with no evidence of inflow boundary fluxes seriously perturbing the model chemistry. BENZ reacts slowly and so inappropriate boundary concentrations would show up in the flux budget. We can see that the emissions outstrip the net export of BENZ by over a factor of seven, giving rise to a systematic trend toward increased BENZ mass loading during the days simulated. Because BUDI is destroyed rather rapidly, the boundary inflow flux suggests that the BUDI boundary concentrations may be too high with respect to emissions because the emitted mass is less than a third of the mass lost due to chemical destruction. The mass imbalance is localized near the inflow boundaries because of the rapid destruction, however, so no adjustment was made.

Table 5-3. A Summary of Major Sources and Sinks of the

Toxic Chemicals in the Atlanta Modeling Domain for the

Base Run for 30-31 July 1987

(units are tons $\left[\mathrm{CH}_{4}\right.$ equivalent mass])

\begin{tabular}{cccccc}
\hline Specie & Emission & Advection & Chemistry & Initial Mass & Final Mass \\
\hline FORM & 9 & -43 & 30 & 105 & 103 \\
ACET & 129 & -85 & -42 & 81 & 83 \\
BENZ & 53 & 7 & -1 & 30 & 90 \\
BUDI & 5 & 11 & -16 & 5 & 5 \\
\hline
\end{tabular}

\subsection{Evaluation of Base Run without Air Toxics}

The initial simulation (QA1) was performed using the UAM-IV inputs as they were received from the DNR. The DNR supplied a model output hourly averaged concentration file for 1999 for direct verification. The daily maximum 1-hour average $\mathrm{O}_{3}$ concentration pattems for July 30 are shown in Figure 5-1 for the QAl and DNR simulations. ${ }^{1}$ The maximum $\mathrm{O}_{3}$ concentration predicted by the DNR is $160.3 \mathrm{ppb}$ while the maximum predicted for QAl is $160.4 \mathrm{ppb}$. Visually, there is no difference between the two concentration patterns. The daily maximum 1 hour average $\mathrm{O}_{3}$ concentration pattern for the second day (31 July) is shown in Figure 5-2, which again shows no apparent difference between the two sets of daily maximum concentrations.

${ }^{1}$ Figures in this section have been placed together following the text. 


\subsection{Comparison of Base Run with and without Toxic Compound Chemistry}

The toxics QA simulation is denoted QA2. Model inputs for QA2 are the same as for QA1, except for the modifications necessary to treat the toxic species, as discussed in Section 5.2. Results for QA1 and QA2 were compared, first in terms of predicied concentrations, and then based on mass budgets. Some differences in the $\mathrm{O}_{3}$ and aldehyde concentrations are expected, as described in Section 2.0. The disaggregated toxics chemistry produces less $\mathrm{O}_{3}$.

The daily maximum 1-hour ave rage surface $\mathrm{O}_{3}$ concentration patterns for QA1 and QA2 are presented in Figures 5-3 and 5-4 for 30 and 31 July, respectively. Generally, the maximum concentrations for QA2 are lower than for QA1, with the differences increasing from the first day to the second. On $30 \mathrm{July}$, predicted maximum concentrations west of Atlanta are noticeably lower for QA2. On 31 July, predicted $\mathrm{O}_{3}$ concentrations southeast of Atlanta are lower for QA2. The locations of the peaks in the concentration fields are basically the same for QA1 ind QA2.

The time series plots in Figure 5-5 show predicted surface $\mathrm{O}_{3}$ concentrations at Dawsonville and MLK MARTA Station for both QA1 and QA2. The largest differences, while slight, occur at midday when the maximum $\mathrm{O}_{3}$ is predicted. The differences in the maximum daily $\mathrm{O}_{3}$ concentration pattem are shown in Figures 5-6 and 5-7 for 30-31 July, respectively. On $30 \mathrm{July}$, the difference plot indicates that predicted $\mathrm{O}_{3}$ for QA2 is 5 to $10 \mathrm{ppb}$ lower over a broad area northwest of Atlanta. The maximum grid cell difference is $10 \mathrm{ppb}$, although the domain maximum concentrations agree within $1 \mathrm{ppb}$. On 31 July (Figure 5-7), the concentration differences increase, with a maxinum difference of $22 \mathrm{ppb}$. This maximum difference in the $\mathrm{O}_{3}$ pattern occurs in the vicinity of Cedar Grove. The domain maximum $\mathrm{O}_{3}$ prediction for $\mathrm{QA2}$ is $167 \mathrm{ppb}$, compared to $176 \mathrm{ppb}$ for QA1.

The daily maximum fields of $\mathrm{NO}_{\mathrm{r}}$ and VOC for $\mathrm{QA1}$ and QA2 were also compared. The daily maximum 1hour average surface VOC concentrations for 31 July are shown in Figure 5-8. The concentration fields show very little difference between QA1 and QA2 simulations. The peak concentration differed by less than one ppb. Figure 5-9 displays the daily maximum 1 hour average surface $\mathrm{NO}_{\mathrm{x}}$ concentrations for $31 \mathrm{July}$. Visually, there is no difference between the QA1 and QA2 fields. The maxima differ by less than $0.1 \mathrm{ppb}$. The daily maximum 1-hour surface FORM concentration fields are shown for QA1 and QA2 for 31 July in Figure 5-10. The QA1 simulation shows slightly higher peak FORM concentrations ( $23.7 \mathrm{vs.} 22.8 \mathrm{ppb}$ ) when compared to the toxics chemistry simulation.

\subsection{Mass Budget Analysis}

A mass budget analysis was also conducted to compare chemical production for the QA1 and QA2 simulations. First, the cumulative chemistry over the two episode days was examined. The net production and destruction of selected species are presentel in Table 5-4. This table indicates that the chemistry of ALD2 has been significantly altered by the disaggregation of the CBM-IV chemical scheme. The amount of ALD2 destroyed in the original scheme is larger than the combined destruction of ACET and HALD2 in the toxics scheme. This result is probably due to the slower photolysis of ACET.

Table 5-4 indicates that the chenustry of CBM-IV organic species that are not affected by the change in the chemical mechanism seems to tie relatively unchanged as well. The fact that less $\mathrm{O}_{3}$ (10\% less) is being produced seems to be due mainly to the reduced rate of production of species which mediate the $\mathrm{NO}$ to $\mathrm{NO}_{2}$ conversion (e.g. $\mathrm{XO}_{2}$ radical species). The aldehyde destruction chemistry is a significant producer of $\mathrm{XO}_{2}$. 
Table 5-4. A Summary of the Chemical Production of $\mathrm{O}_{3}$ and Other Chemicals over the Period 30-31 July 1987 in the Atlanta Modeling Domain

(units are tons)

\begin{tabular}{ccc}
\hline Chemical Specie & $\begin{array}{c}\text { Base Run } \\
\text { (QA1) }\end{array}$ & $\begin{array}{c}\text { Toxics Chemistry Run } \\
\text { (QA2) }\end{array}$ \\
\hline O3 & 5173 & 4622 \\
OLE & -196 & -197 \\
TOL & -185 & -190 \\
XYL & -175 & -177 \\
FORM & 39 & 30 \\
ALD2/ACET & $-74($ ALD2) & $-42($ ACET) \\
ETH & -20 & -27 \\
PAN & 512 & 458 \\
HNO3 & 2056 & 2068 \\
HPAN & - & 17 \\
\hline
\end{tabular}




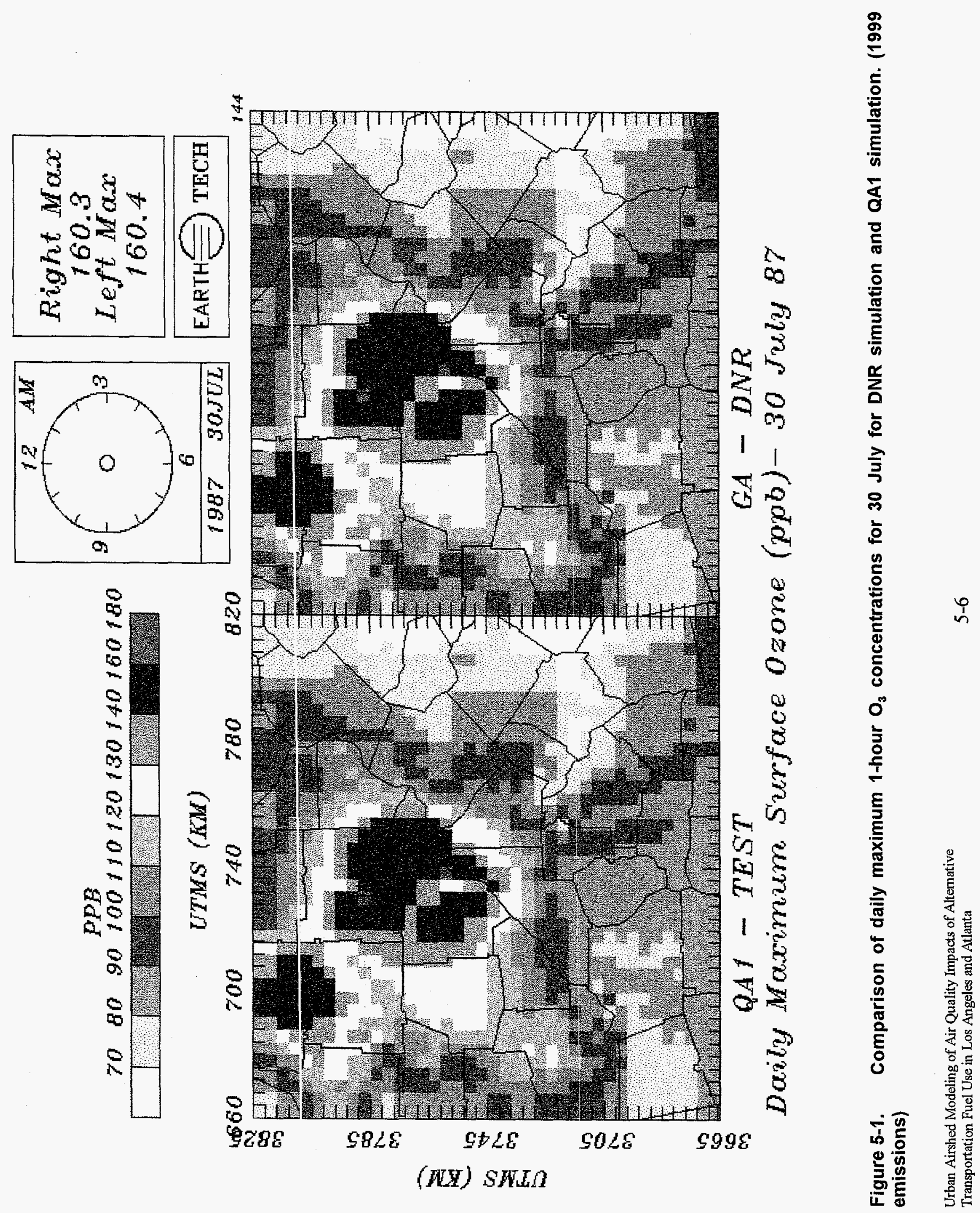




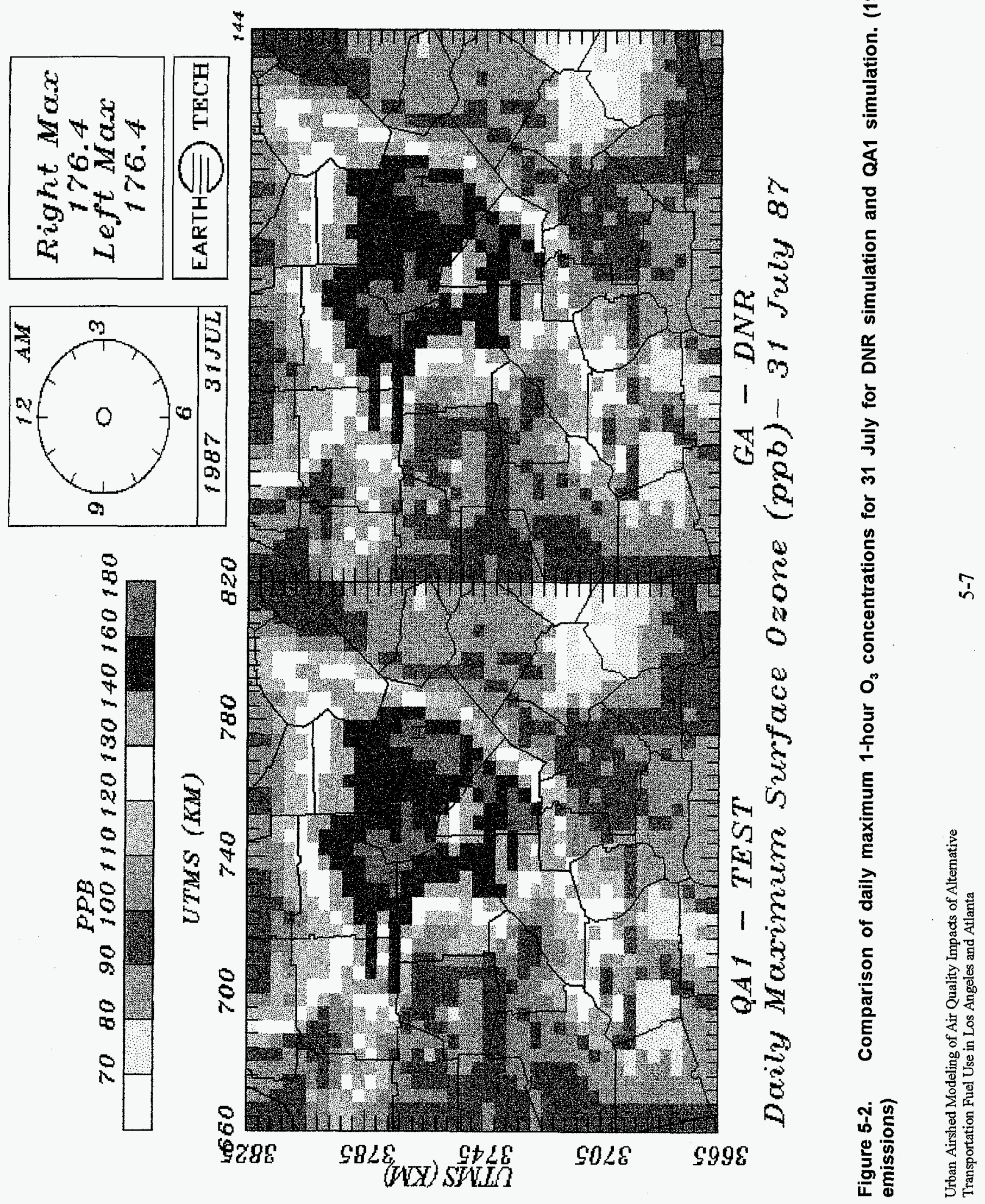




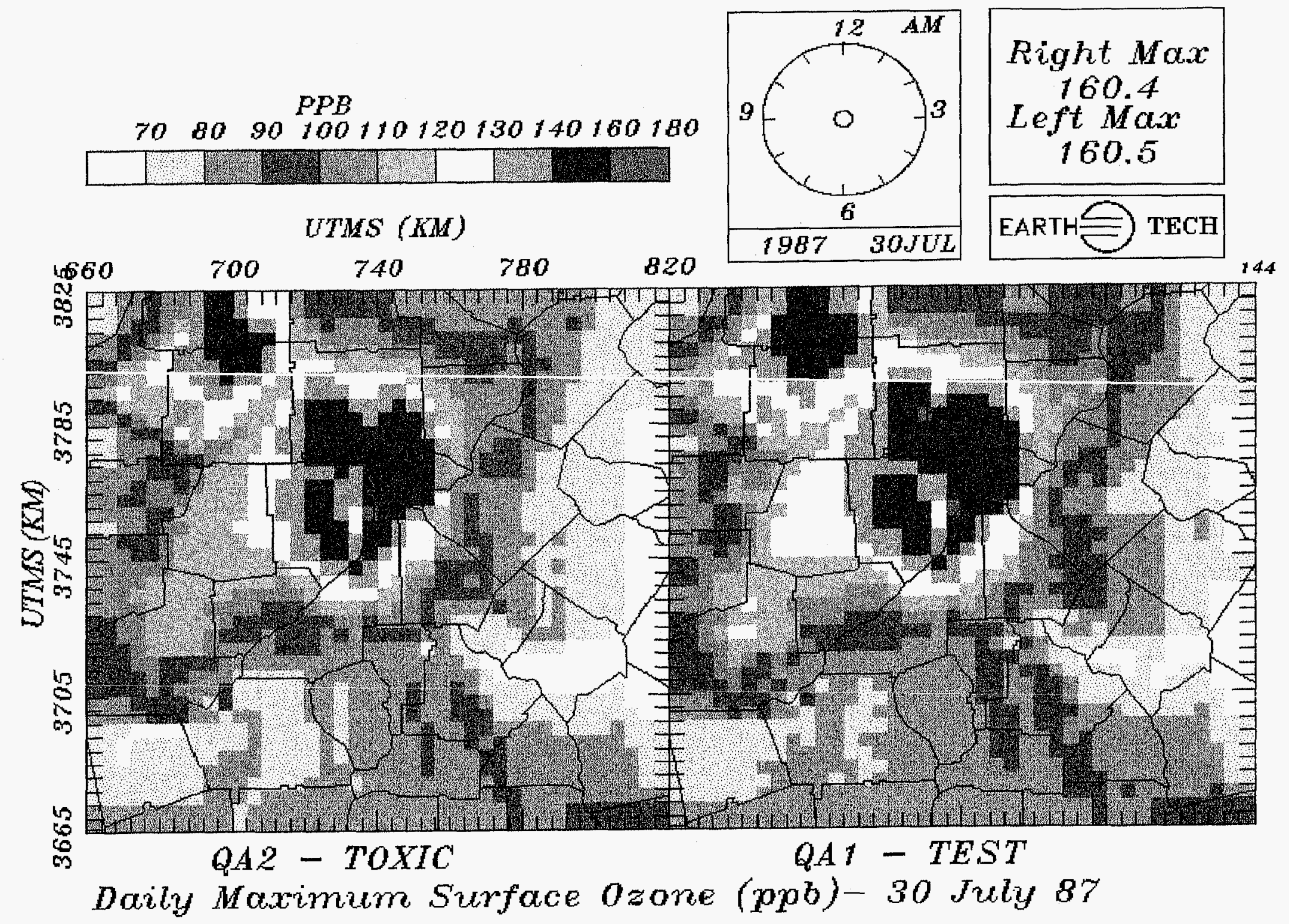

Figure 5-3. Comparison of daily maximum 1-hour surface $O_{3}$ concentrations for 30 July for Atlanta for QA1 (Base) and QA2 (Air Toxics) QA simulations. (1999 emissions) 


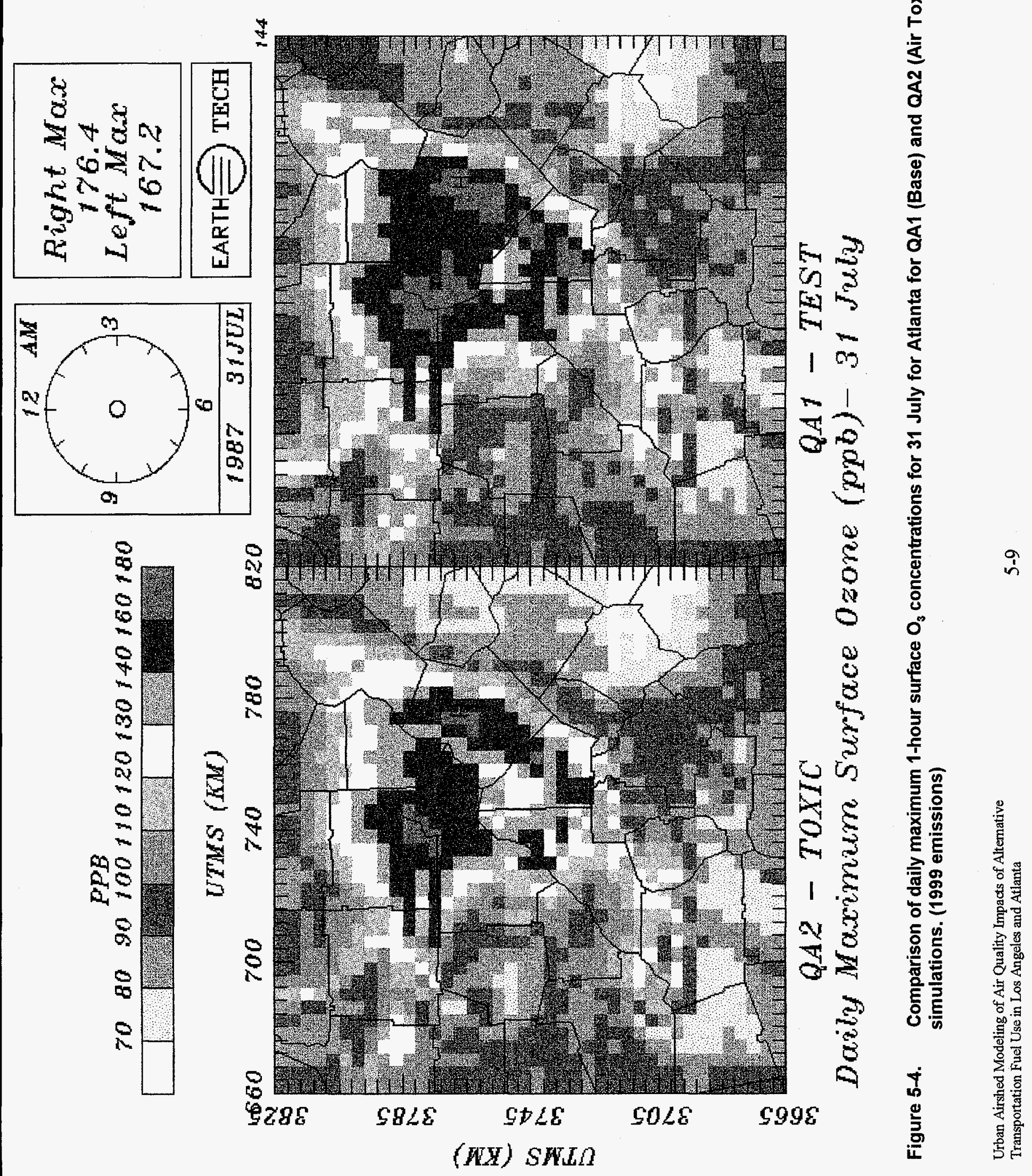




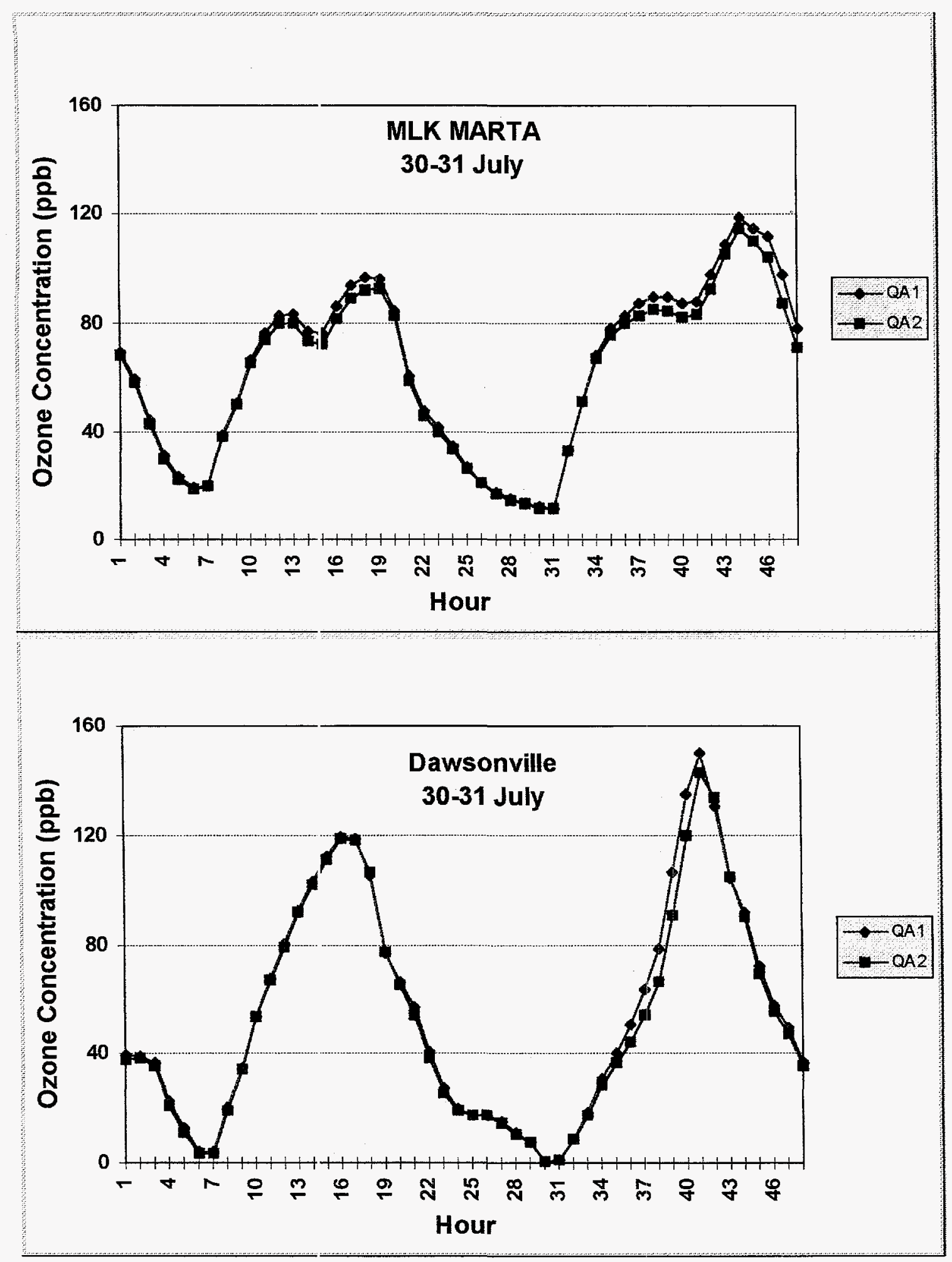

Figure 5-5. Hourly predicted 1-hour surface ozone concentrations at MLK MARTA (top) and Dawsonville (bottom) for 30-31 July 1987 for QA1 (Base) and QA2 (Air Toxics) simulations. 


\section{DAILY MAXIMUM OZONE DIFFERENCE - (BASE - TOXIC)}

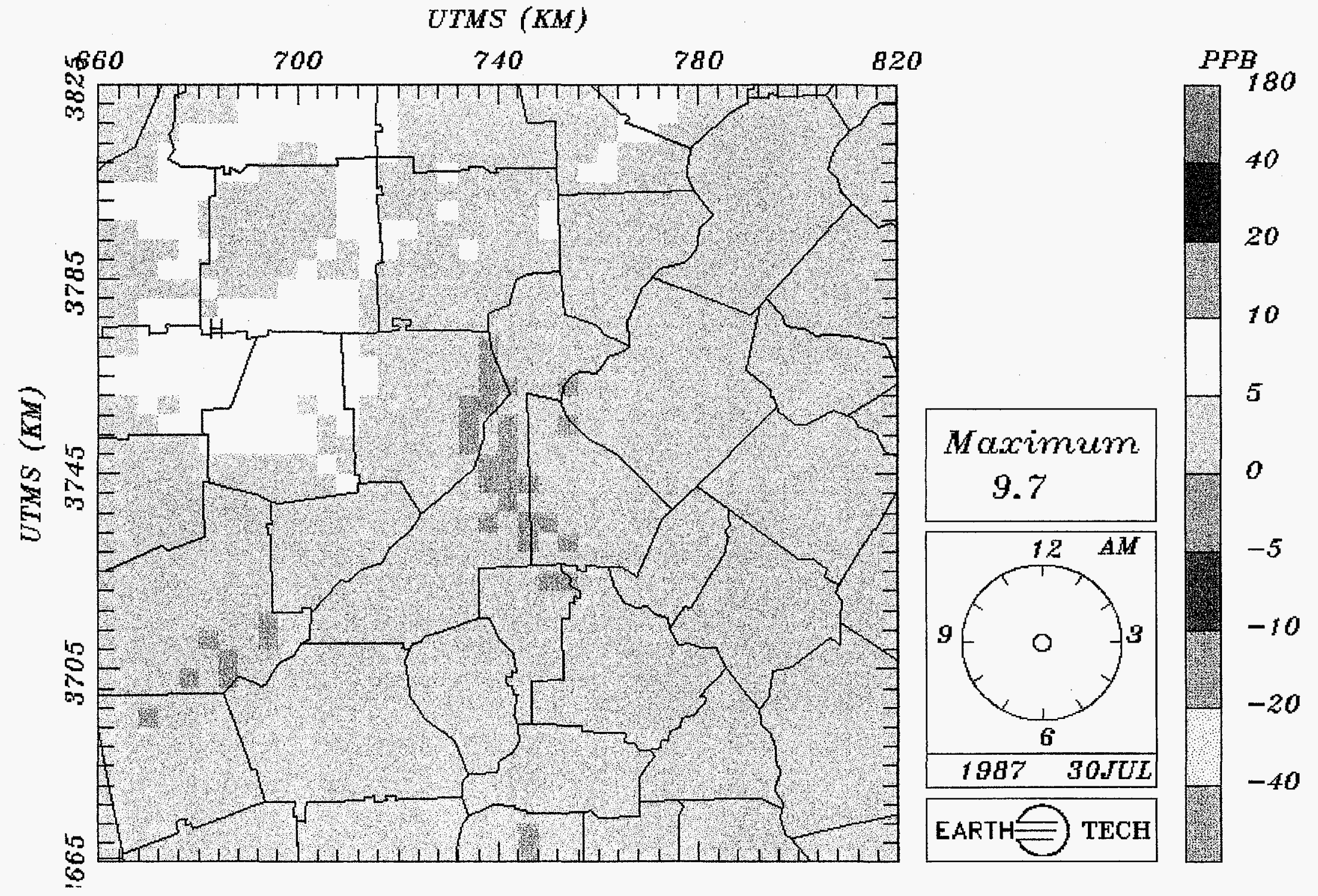

Figure 5-6. Difference in daily maximum 1-hour surface $O_{3}$ concentration for Atlanta for 30 July for QA1 (Base) minus QA2 (Air Toxics) QA simulations. (1999 emissions) 


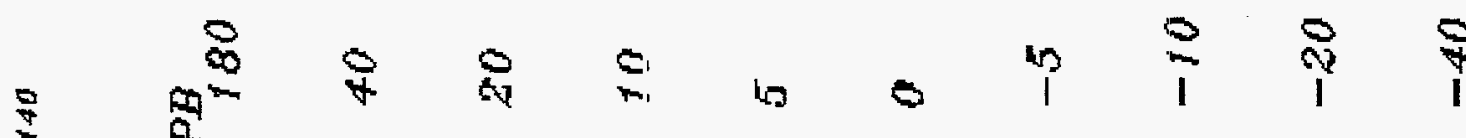

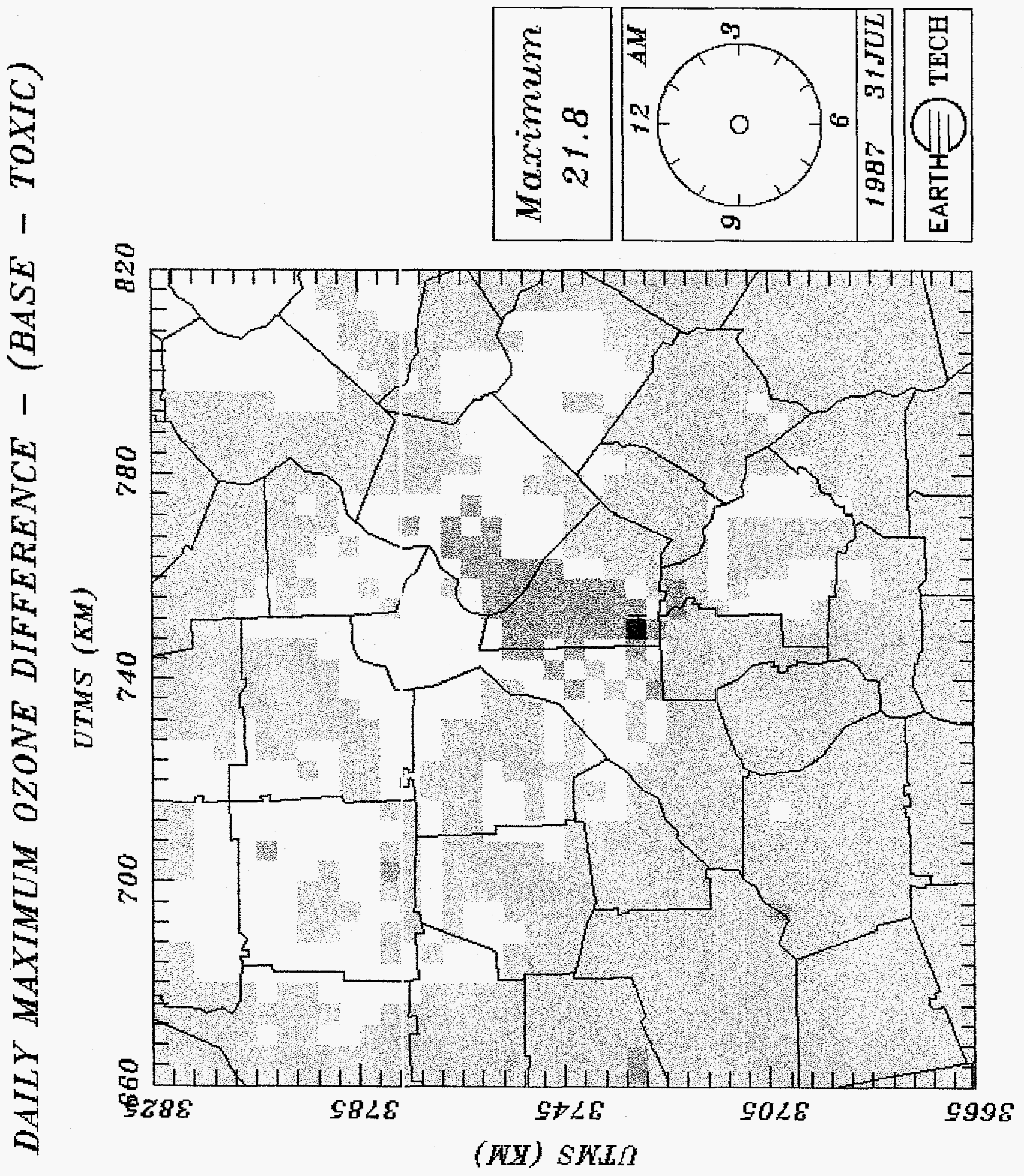

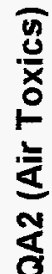

号

5

흔

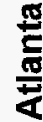

ᄒํㄴ

을

o

언

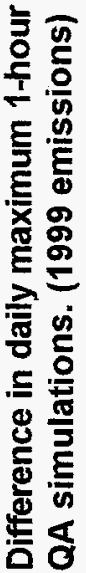

ํㅜㅇ 

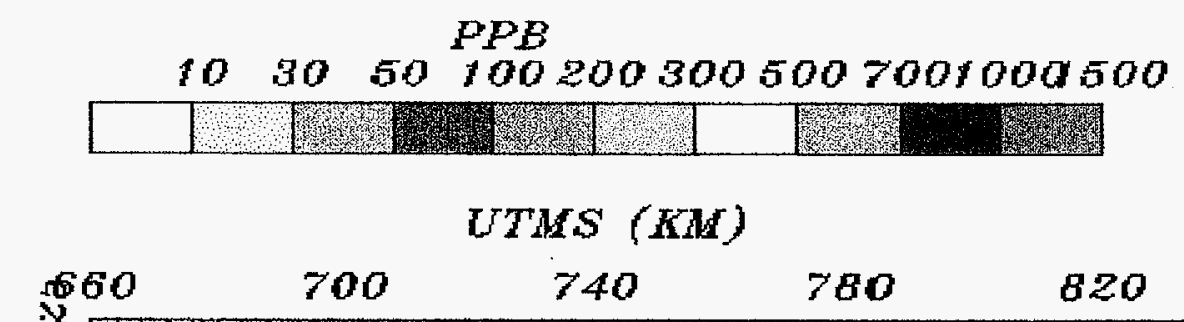

\section{Right $M a x$ 697.7 \\ Left $M a x$ 697.5}

EARTH $\fallingdotseq \mathrm{TECH}$

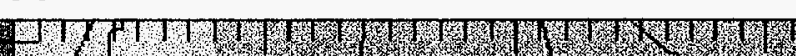

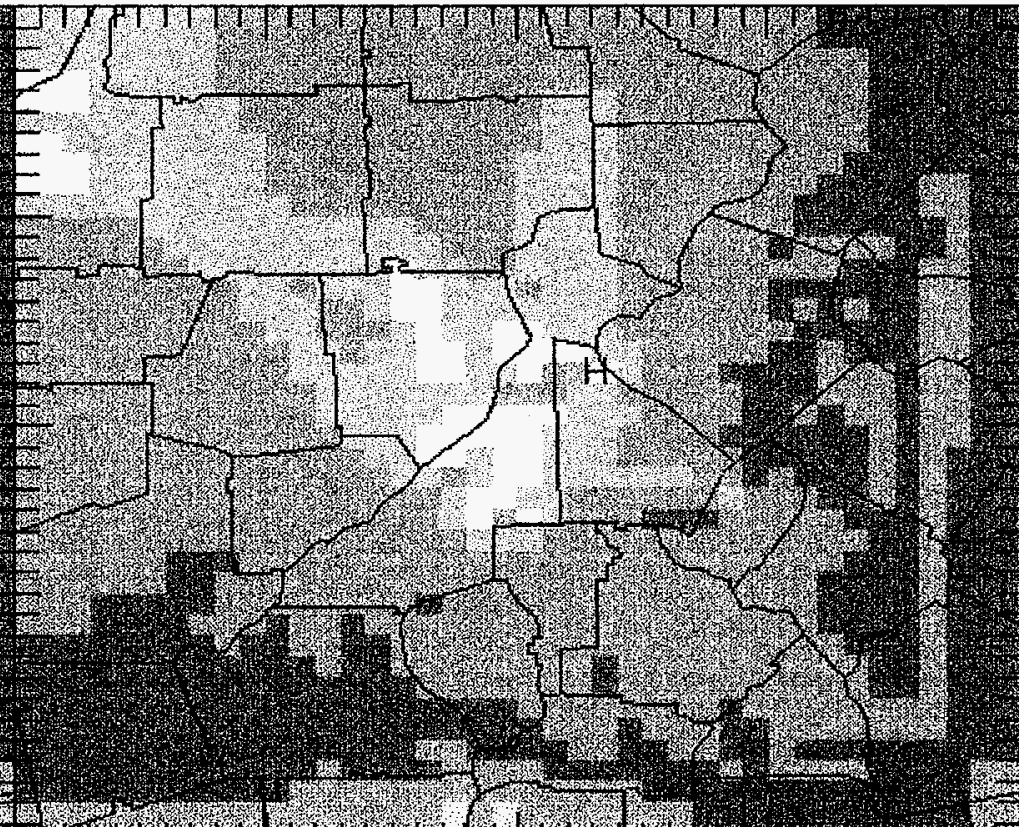

8

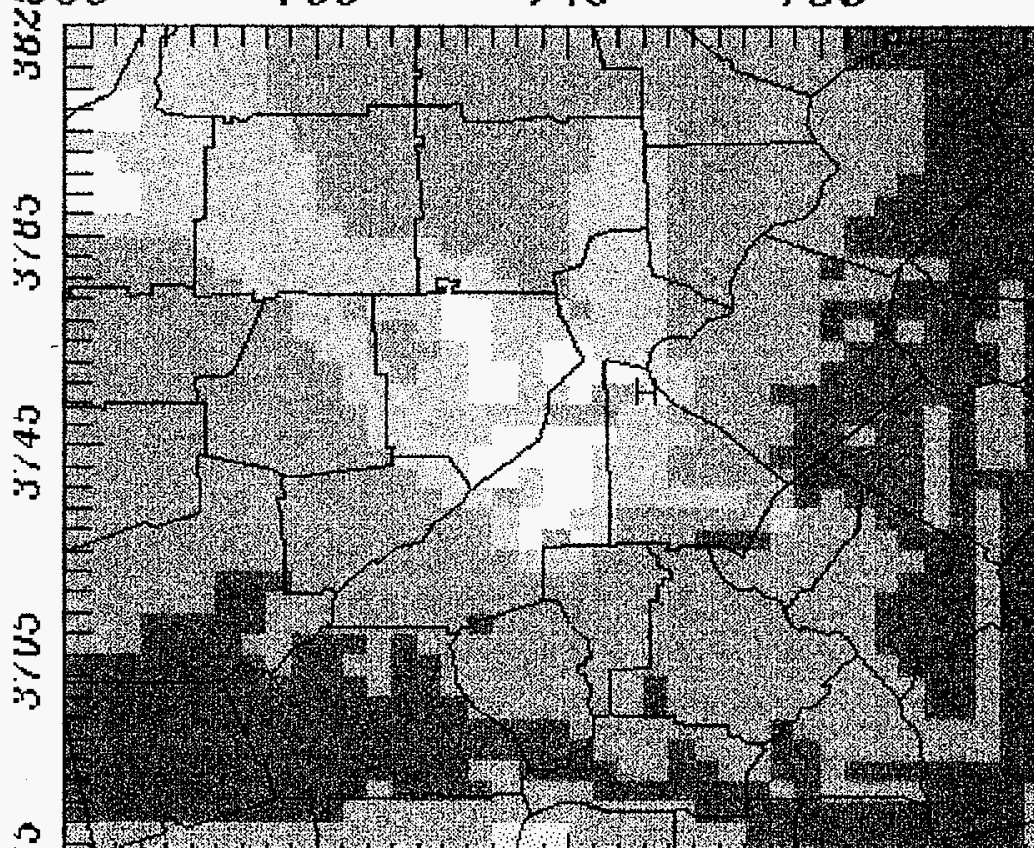

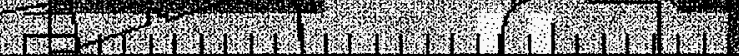

$Q A 1-T E S T$
$(p p b)-31$ JuLy 87

Figure 5-8. Daily maximum 1-hour surface VOC concentrations for Atlanta for 31 July for QA1 (Base) and QA2 (Air Toxics) QA simulations. (1999 emissions) 


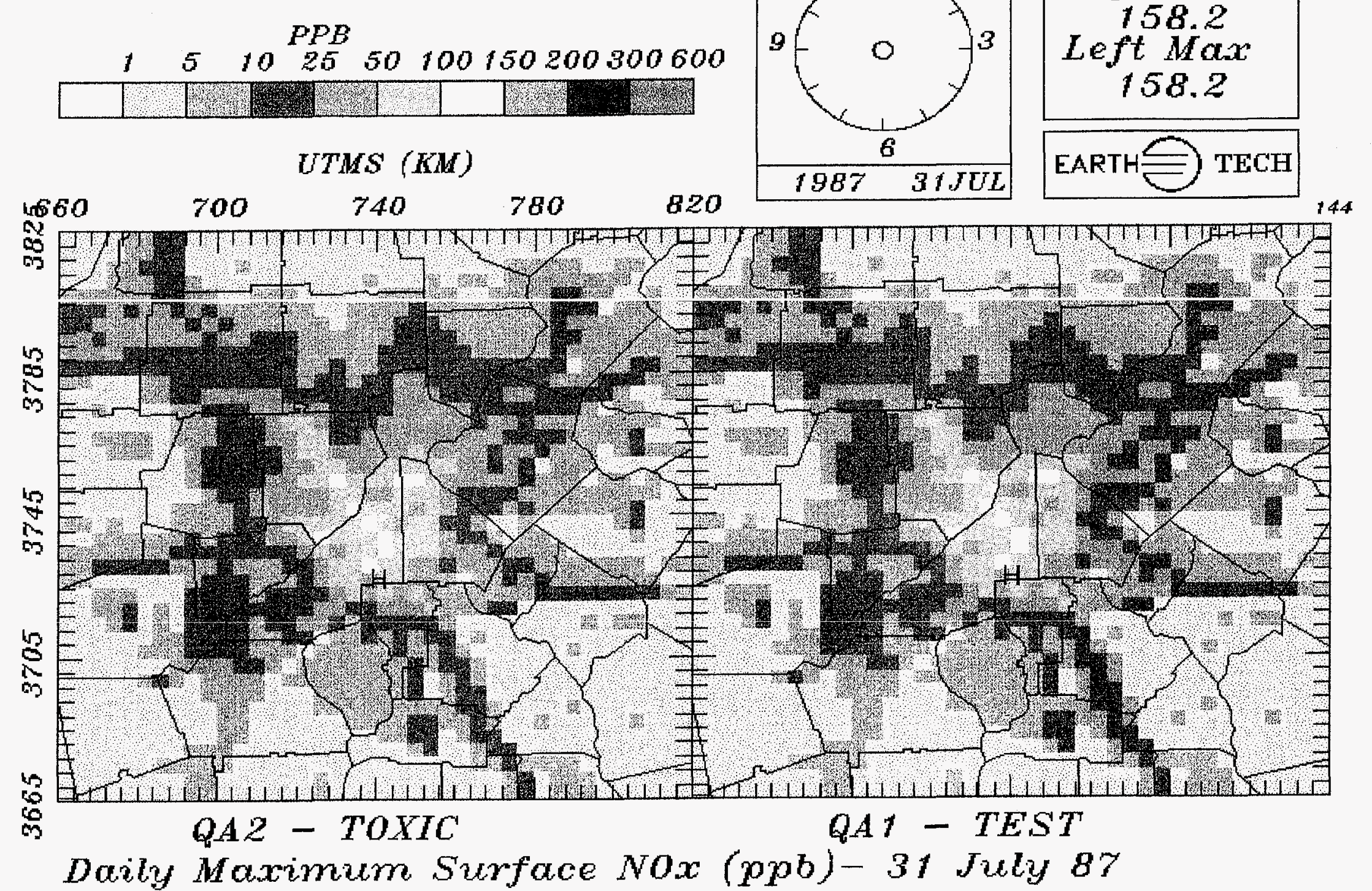

Figure 5-9. Daily maximum 1-hour surface $\mathrm{NO}_{\mathrm{x}}$ concentrations for Atlanta for 31 July for QA1 (Base) and QA2 (Air Toxics) QA simulations. (1999 emissions) 


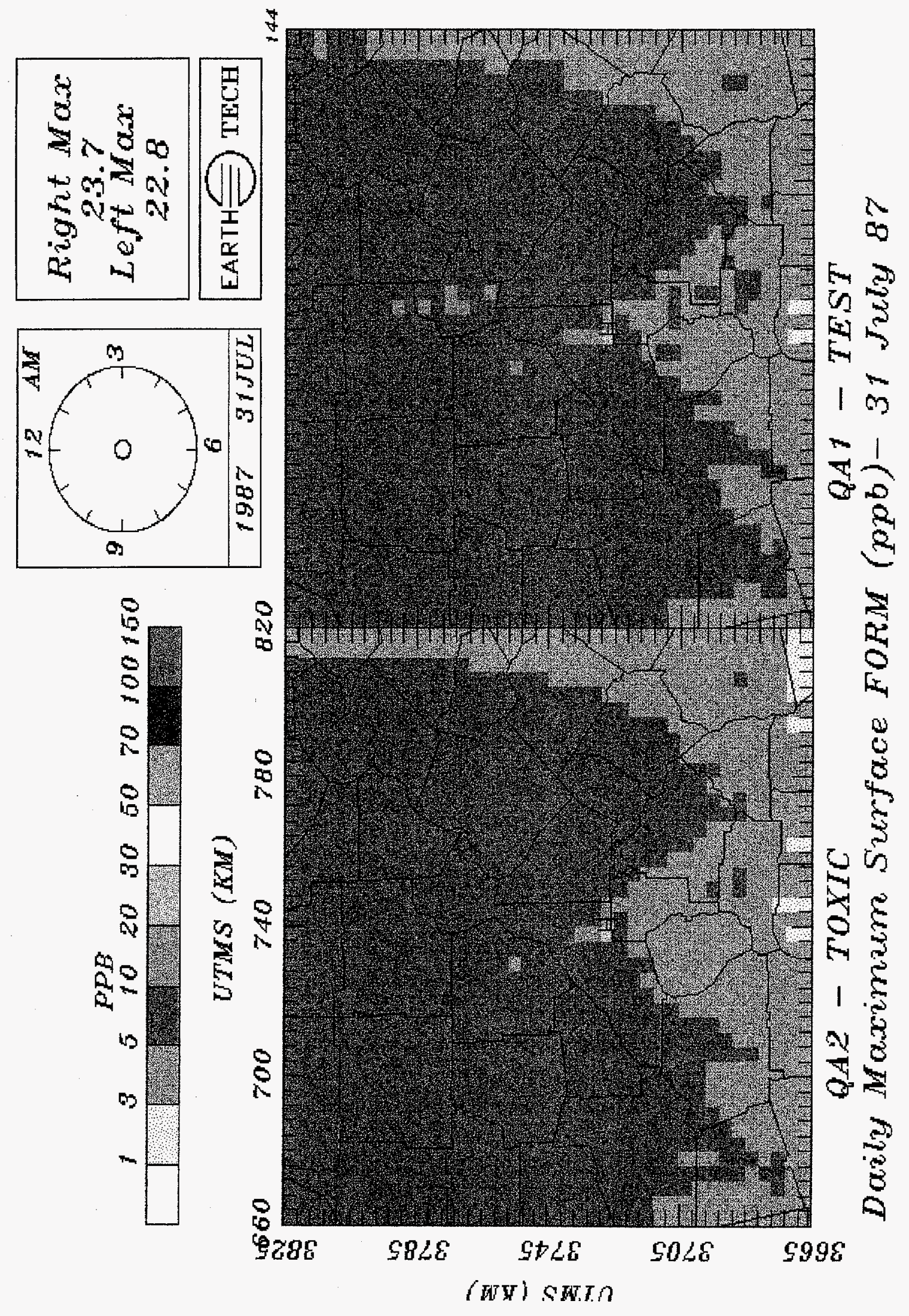

g

莺

$\overleftarrow{d}$

氙

넌

$\frac{y}{2}$

믈

ชี

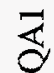

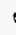

롤

m

옹

葶

$\frac{n}{n}$

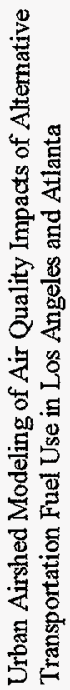




\subsection{Analysis of Future Year Modeling Results for Los Angeles}

Three future UAM-IV model simulations were made for the year 2007 . The 1987 base year emissions had appropriate growth and control factors applied to project the emissions to the year 2007. Such projections become rather uncertain after a few years because of the vagaries of the economy, unforeseen shifts in demography, and the complex interplay between evolving emission control programs. The use of AFVs will result not only in changes in the on-road mobile emissions component, but also in emission changes associated with fuel processing and distribution.

Three emission inventories were prepared for the future year modeling. The first contained all point and area source emissions in the Los Angeles area except those associated with on-road vehicles, plus gasoline fuel distribution and marketing. In addition, it contained emissions for all diesel vehicles, both on- and off-road, and emissions for all heavy-duty gasoline-fueled motor vehicles. This emissions scenario was called $\mathrm{S} 1$, and when modeled, provides an indication of what fraction of the surface $\mathrm{O}_{3}$ concentrations are due to sources other than light- and medium-duty gas vehicles. The sources comprising the S1 scenario was called the unaffected sources since they were not involved in or affected by motor vehicle fuel substitution.

The second inventory consisted of emissions from all light- and medium-duty gasoline on-road motor vehicle using RFG as fuel. In addition, it included emissions from those point and area sources associa ted with gasoline-fuel distribution and marketing. These emissions, when added to the $\mathrm{S} 1$ inventory emissions, produced the 2007 RFG scenario. This scenario was used to estimate the future year $\mathrm{O}_{3}$ air quality for an inventory representing a gasoline-fueled motor vehicle fleet. In a similar manner, an emissions scenario was developed that assumed all light- and medium-duty gasoline vehicles were instead dedicated to use of CNG. This inventory, when added to the S1 inventory, produced the CNG scenario inventory.

As indicated in the introduction, a major focus of this study is to quantify the degree to which the use of CNG may affect ambient concentrations and population exposures to $\mathrm{O}_{3}$ and toxics during a severe $\mathrm{O}_{3}$ episode. In this section we present and analyze the results of the three UAM simulations where the changes in model inputs reflect the effects of alternative motor vehicle fuels.

\subsection{Surface Emissions Inventory Description}

Our focus is on surface emission sources of VOCs and $\mathrm{NO}_{x}$ the major precursors of $\mathrm{O}_{3} .{ }^{12}$ Of secondary interest are the emissions of the toxic compounds FORM, ACET, BENZ, and BUDI. The surface emissions inventory consists of four major components; biogenics, low-level points, off-road area emissions (fixed plus stationary), and on-road mobile emissions. We summarize the VOC and $\mathrm{NO}_{\mathrm{x}}$ emissions components for each of the three emissions inventories in Table 6-1. In this table the daily tonnages of emissions for $\mathrm{NO}_{\mathrm{x}}$ are expressed as $\mathrm{NO}_{2}$ equivalents and the VOCs are expressed in terms of

\footnotetext{
${ }^{1}$ In the SCAQMD, VOC emissions are typically referred to as ROG. For consistency with the Atlanta nomenclature, we will use the term VOC in this section.

${ }^{2}$ Organic emissions in Sections 6 and 7 are stated as VOCs, while emission factors in Section 2 are stated as TOG. One important distinction between TOG and VOC emissions is that TOG includes methane, while VOC does not.
} 
$\mathrm{CH}_{4}$ equivalent mass for only the primary CB-IV species (e.g., no BENZ or BUDI). For comparison, elevated point source emissions are also contained in Table 6-1.

As expected, the emissions dati indicate that biogenic emissions in Los Angeles constitute a relatively minor fraction of the total VOC smissions budget. No soil $\mathrm{NO}_{\mathrm{x}}$ emissions were contained in the SCAQMD emission inventory. Motor vehicle emissions of $\mathrm{NO}_{\mathrm{x}}$ are dominated by diesel vehicles and heavy duty trucks, which are included in unaffected sources. For $\mathrm{S1}$, area and low point emissions represent approximately $60-70 \%$ of the total VOC and $\mathrm{NO}_{\mathrm{x}}$ emissions. The CNG fueled vehicle emissions add essentially no VOCs and only one-fourth the amount of $\mathrm{NO}_{\mathrm{x}}$ emissions of RFG fueled vehicles.

Table 6-1. Estimated Emissions in Los Angeles Modeling Domain for 2007 for S1 Scenarios and RFG and CNG Scenario Incremental Emissions

\begin{tabular}{|c|c|c|c|c|}
\hline \multirow[b]{2}{*}{ Pollutant } & \multirow[b]{2}{*}{ Source Type } & \multirow{2}{*}{$\begin{array}{l}\text { Unaffected } \\
\text { Sources } \\
\text { (tons/day) }\end{array}$} & \multicolumn{2}{|c|}{$\begin{array}{c}\text { Future Year Motor Vehicle } \\
\text { Incremental Emissions (tons/day) }\end{array}$} \\
\hline & & & RFG & CNG \\
\hline \multirow[t]{6}{*}{ VOC } & Motor Vehicle & 28 & 141 & 3.7 \\
\hline & Area & 234 & 19 & 2.7 \\
\hline & Low Level Point & 163 & 3.2 & 0.5 \\
\hline & Elevated Pioint & 3.2 & 0 & 0 \\
\hline & Biogenics & 160 & 0 & 0 \\
\hline & Total VOC & 560 & 160 & 6.9 \\
\hline \multirow[t]{6}{*}{$\mathrm{NO}_{x}$} & Motor Vehicle & 148 & 198 & 54 \\
\hline & Area & 229 & 0 & 0 \\
\hline & Low Level Point & 109 & 0 & 0 \\
\hline & Elevated Pioint & 12 & 0 & 0 \\
\hline & Biogenics & 0 & 0 & 0 \\
\hline & Total $\mathrm{NO}_{\mathrm{x}}{ }^{\mathrm{a}}$ & 500 & 200 & 54 \\
\hline
\end{tabular}

a Totals are rounded to two significant figures and are $\mathrm{VOC}$ as non methane hydrocarbon containing no $\mathrm{CO}$ and $\mathrm{CH}_{4}$. 


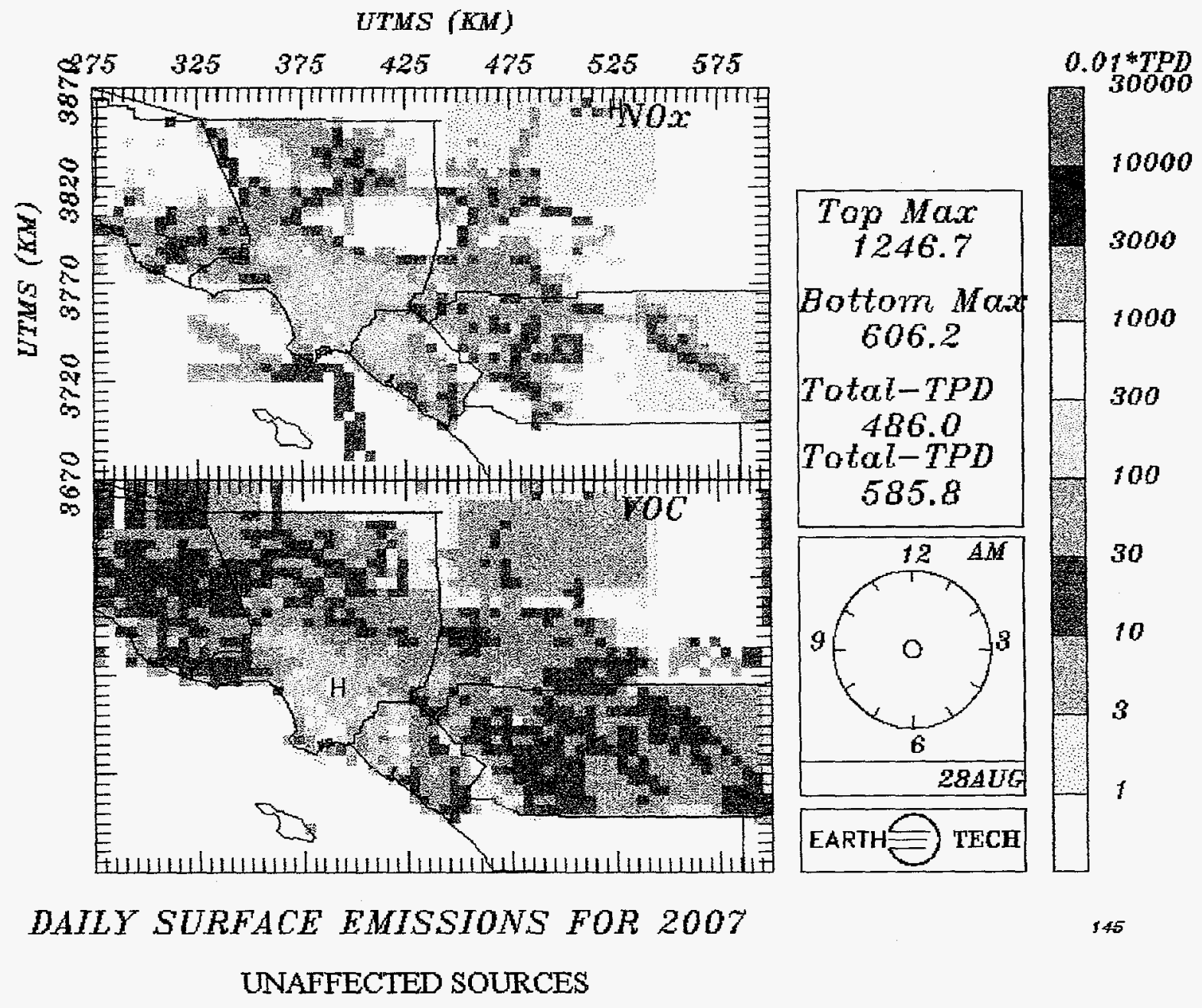

Figure 6-1. Daily VOC and $\mathrm{NO}_{\mathrm{x}}$ emission density plots with on-road light- and medium-duty vehicle emissions removed for Los Angeles for 28 August for 2007. 
The spatial distribution of surlace emissions of $\mathrm{NO}_{\mathrm{x}}$ and VOC for the $\mathrm{S} 1$ inventory is shown in Figure 6-1. This figure indicates that within the modeling domain there are no emissions from San Diego County. Also evident is the absence of any VOC emissions from the desert areas of San Bernardino County. This pattern of emissions is consistent with the emissions summaries presented in SCAQMD (1994). Although the peak $\mathrm{NO}_{\mathrm{x}}$ emission rate pir cell is more than twice as large as that of VOCs (12 vs. 6 ton/day) there is more total tonnage of VOC; emitted per day than $\mathrm{NO}_{x}$. The greatest VOC emissions are in downtown Los Angeles and near Long Beach, which is expected given the petroleum industrial concentration. The largest non-elevated point $\mathrm{NO}_{x}$ emissions occur near the Victorville and Barstow areas. There seems to be a spurious column of VOC emissions in the most easterly cells in San Bernardino County. Major highways and shipping routes show up as corridors of elevated $\mathrm{NO}_{\mathrm{x}}$ emissions.

The diurnal patterns of doma in-total $\mathrm{NO}_{\mathrm{x}}$ and VOC emissions by major component for the $\mathrm{S} 1$ inventory are shown in Figure 6-2. Diesel emissions peak around 0700 LST in the morning and again around 1700 LST in the evening. Surprisingly, biogenic emissions appear to peak later in the day around 1800 LST before collapsing to a small value during the night. Low-level point source VOC emissions show an activity profile that resembles a square wave signal between 0800 and 1500 LST corresponding to the work day. The off-road and on-road emission profiles are very similar, suggesting that both are dominated by similar emission processes and activity profiles.

The speciation of the RFG on-road mobile emissions is presented in Table 6-2. This table shows several interesting features, including, a significant lack of FORM emissions from RFG fueled vehicles. From standard gasoline, one expects of the order $2 \%$ of the $\mathrm{CH}_{4}$ equivalent mass to be FORM. For RFG, there appears to be very little FOlRM or ACET present. There are relatively large emissions of aromatic compounds (TOL and XYL) as well as the toxic compound BENZ. Conversely, as one would expect, motor vehicles emit very small, if any amounts of a biogenic compound such as isoprene.

\section{Table 6-2. RFG Scenario Selected Speciation of Gasoline Powered On-Road Motor Vehicle Emissions for Los Angeles for 2007 Expressed as $\mathrm{CH}_{4}$ Equivalents from GEMAP}

\begin{tabular}{cc}
\hline Toxics CB-IV Species & $\begin{array}{c}\text { Domain Wide } \\
\text { Emissions (tons/day) }\end{array}$ \\
\hline PAR & 92 \\
XYL & 27 \\
TOL & 25 \\
BENZ & 7.7 \\
OLE & 5.5 \\
ETH & 3.7 \\
FORM & 0.71 \\
ACET & 0.19 \\
HALD & 3.2 \\
BUDI & 0.17 \\
ISOP & 0.15 \\
\hline
\end{tabular}




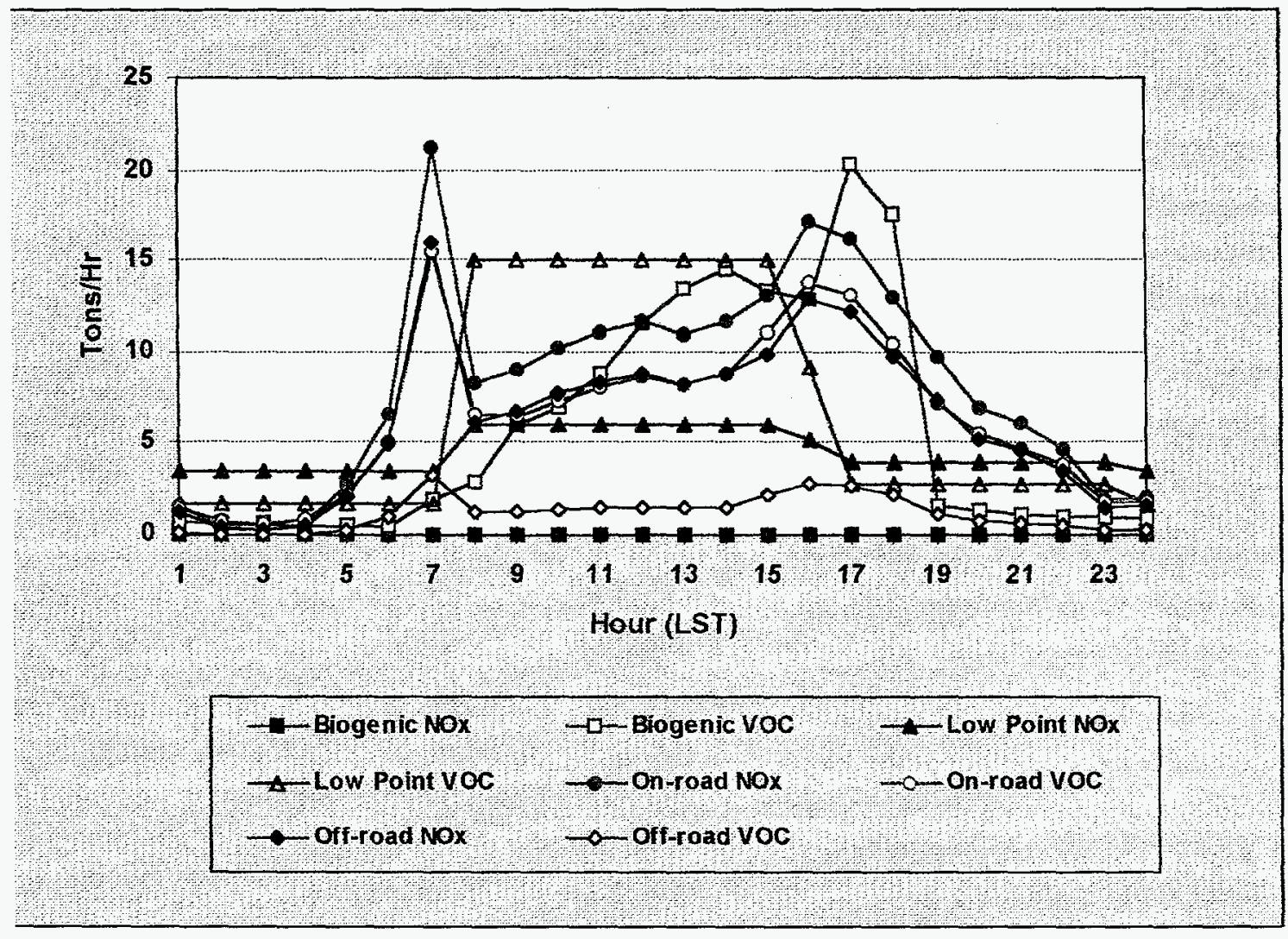

Figure 6-2. Diurnal trend in $\mathrm{NO}_{x}$ and VOC emissions for Los Angeles by emission category for 2007. 
The spatial pattern of daily VOC emissions due to RFG and CNG fueled vehicles is presented in Figure 6-3. This figure indicates that the RFG fueled vehicle emissions are over an order of magnitude larger than those due to CNG fuelec vehicles. Emissions of VOCs from both CNG and RFG fuel use peak in the corridor between the coast and downtown Los Angeles.

Figure 6-4 illustrates the spatial pattern of daily $\mathrm{NO}_{\mathrm{x}}$ emissions due to RFG and CNG fueled vehicles in the Los Angeles modeling domain. As in the case of VOC emissions, the $\mathrm{NO}_{\mathrm{x}}$ emissions peak in the downtown Los Angeles area. The spatial pattern is the same for both fuels. The maximum daily grid-cel 1 and domain-wide total emission rates for $\mathrm{NO}_{\mathrm{x}}$ from $\mathrm{RFG}$ fueled vehicles are each almost four times those from CNG fueled vehicles.

\subsection{Intercomparisons of Maximum Hourly Ozone}

The spatial patterns of predicted daily maximum 1-hour $\mathrm{O}_{3}$ with and without RFG fueled vehicles are displayed in Figure 6-5 for 27 August and Figure 6-6 for 28 August. On 27 August, the difference in maximum $\mathrm{O}_{3}$ is $5 \mathrm{ppb}$. For the $\mathrm{RFG}$ scenario, the maximum is predicted in the San Bernardino mountains north of Pasadena. For Scerario $\mathrm{S} 1$, the maximum $\mathrm{O}_{3}$ is predicted between Reseda and Burbank. On 28 August, the difference in maximum $\mathrm{O}_{3}$ is $13 \mathrm{ppb}$, with the RFG maximum predicted just west of Rubidoux.

The predicted daily maximum 1-hour concentrations with RFG and with CNG fueled vehicles are compared in Figure 6-7 for 27 August and in Figure 6-8 for 28 August. The spatial patterns of predictions with CNG fueled vehicles resemble the S1 scenario more closely than the RFG scenario. Statistics describing predicted peak $\mathrm{O}_{3}$ for the three 2007 Los Angeles emission scenarios are summarized in Table 6-3. Domain-maximum predicted concentrations with CNG increase by $1 \mathrm{ppb}$ and $5 \mathrm{ppb}$, respectively, for 27 and 28 August. The domain-average daily maximum prediction for 27 August is the same for all three scenarios, indicating that the addition of motor vehicle emissions produces decreases in predicted peak $\mathrm{O}_{3}$ in some parts of the domain. For 28 August, the domain-average predicted maximum increased by $1.1 \mathrm{ppb}$ with RFG and $0.3 \mathrm{ppb}$ with CNG.

Table 6-3. Daily Maximum and Average $\mathrm{O}_{3}$ Concentrations in the Los Angeles Modeling Domain for 2007 (units are ppb)

\begin{tabular}{lccc}
\hline \multicolumn{1}{c}{ Statistic } & Emission Scenario & 27 August & 28 August \\
\cline { 2 - 4 } Maximum daily 1-hour & S1 & 128 & 137 \\
Maximum daily 1-hour & RFG & 133 & 150 \\
Maximum daily 1-hour & CNG & 129 & 142 \\
$\begin{array}{l}\text { Domain average 1- } \\
\text { hour }\end{array}$ & S1 & 47.5 & 50.4 \\
$\begin{array}{l}\text { Domain average 1- } \\
\text { hour }\end{array}$ & RFG & 47.5 & 51.5 \\
$\begin{array}{l}\text { Domain average 1- } \\
\text { hour }\end{array}$ & CNG & 47.5 & 50.7 \\
\hline
\end{tabular}




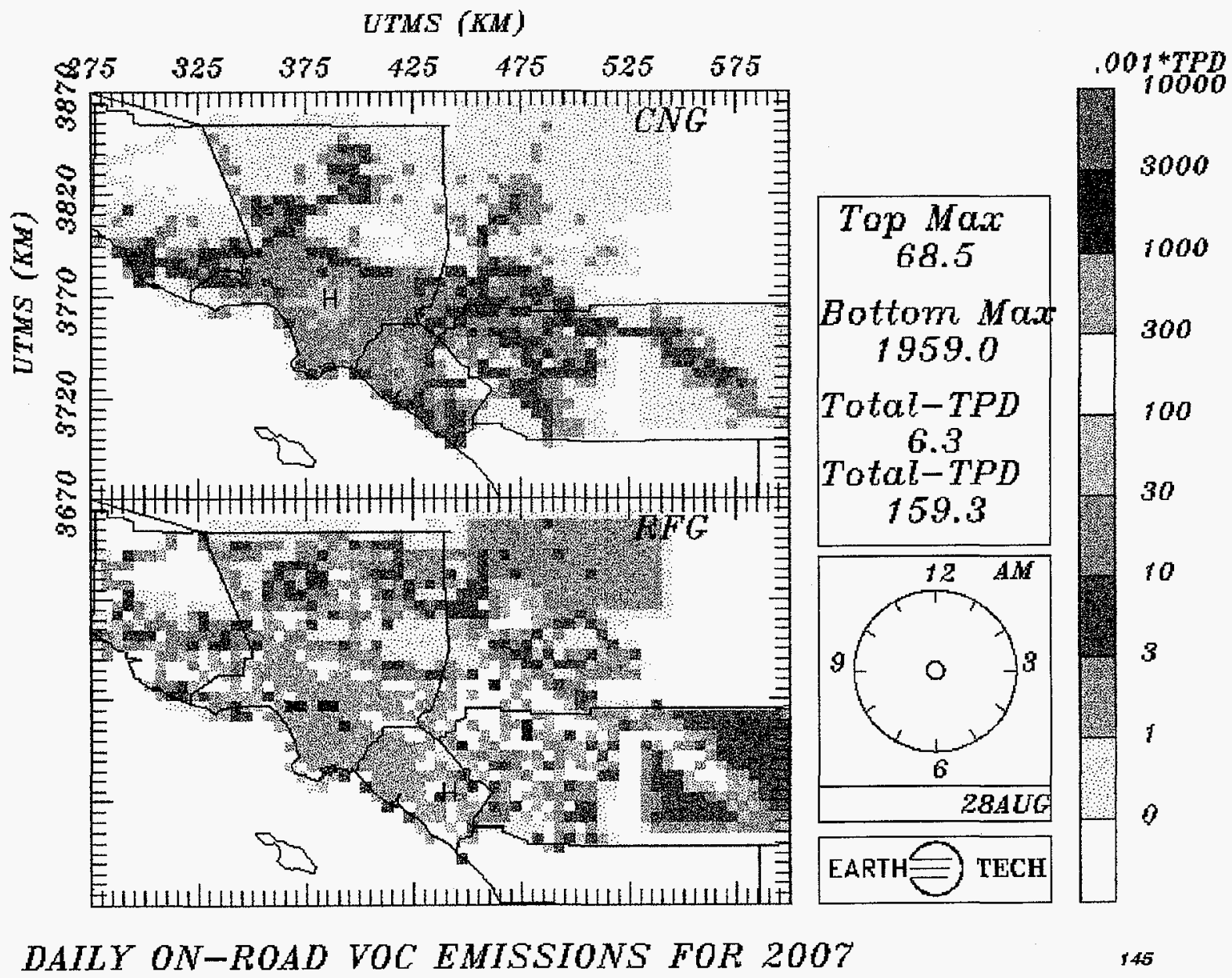

Figure 6-3. Daily VOC emission density plots for CNG and RFG scenarios for Los Angeles for 28 August for 2007. 


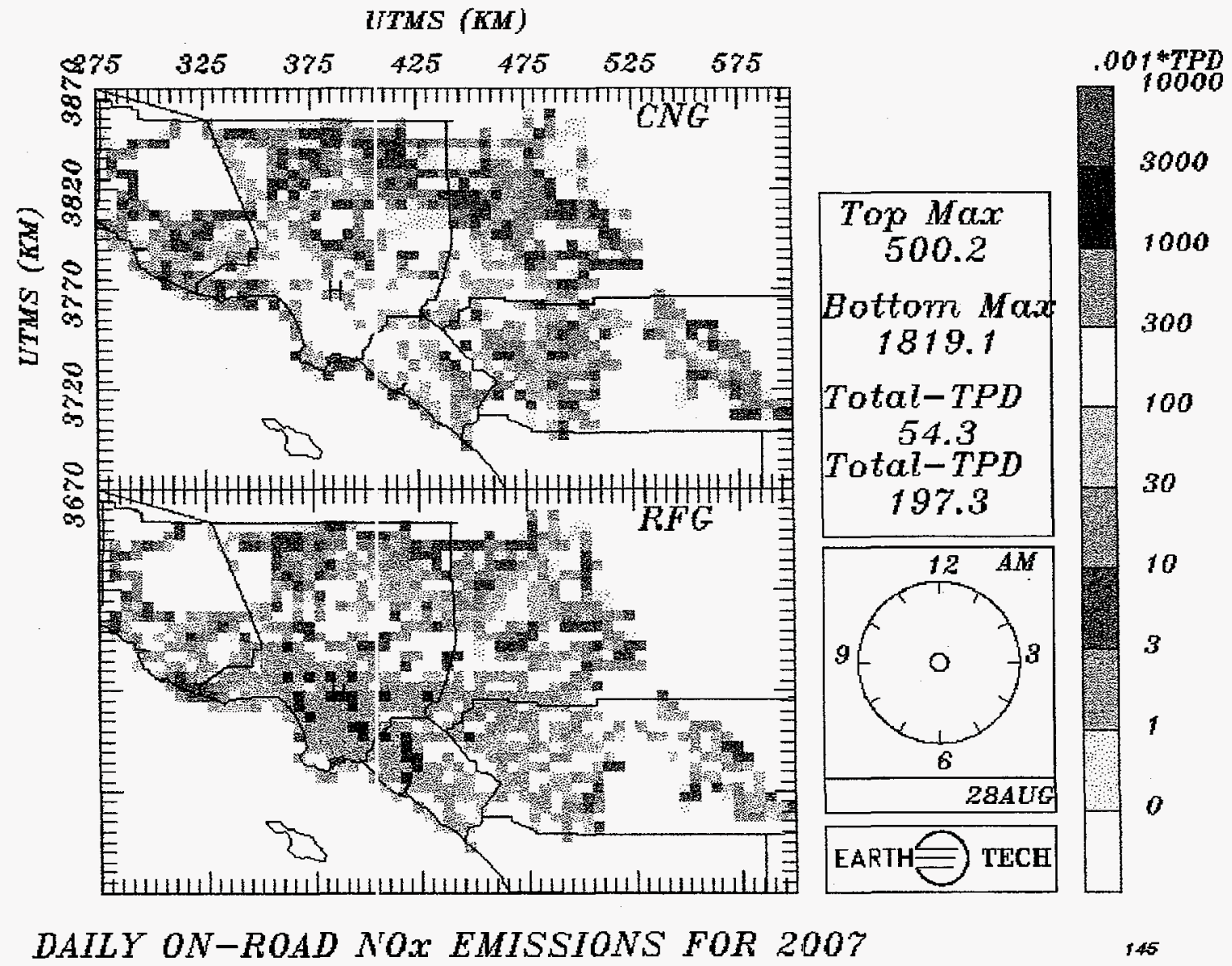

Figure 6-4. Daily NO emission density plots for CNG and RFG scenarios for Los Angeles for 28 August for 2007. 


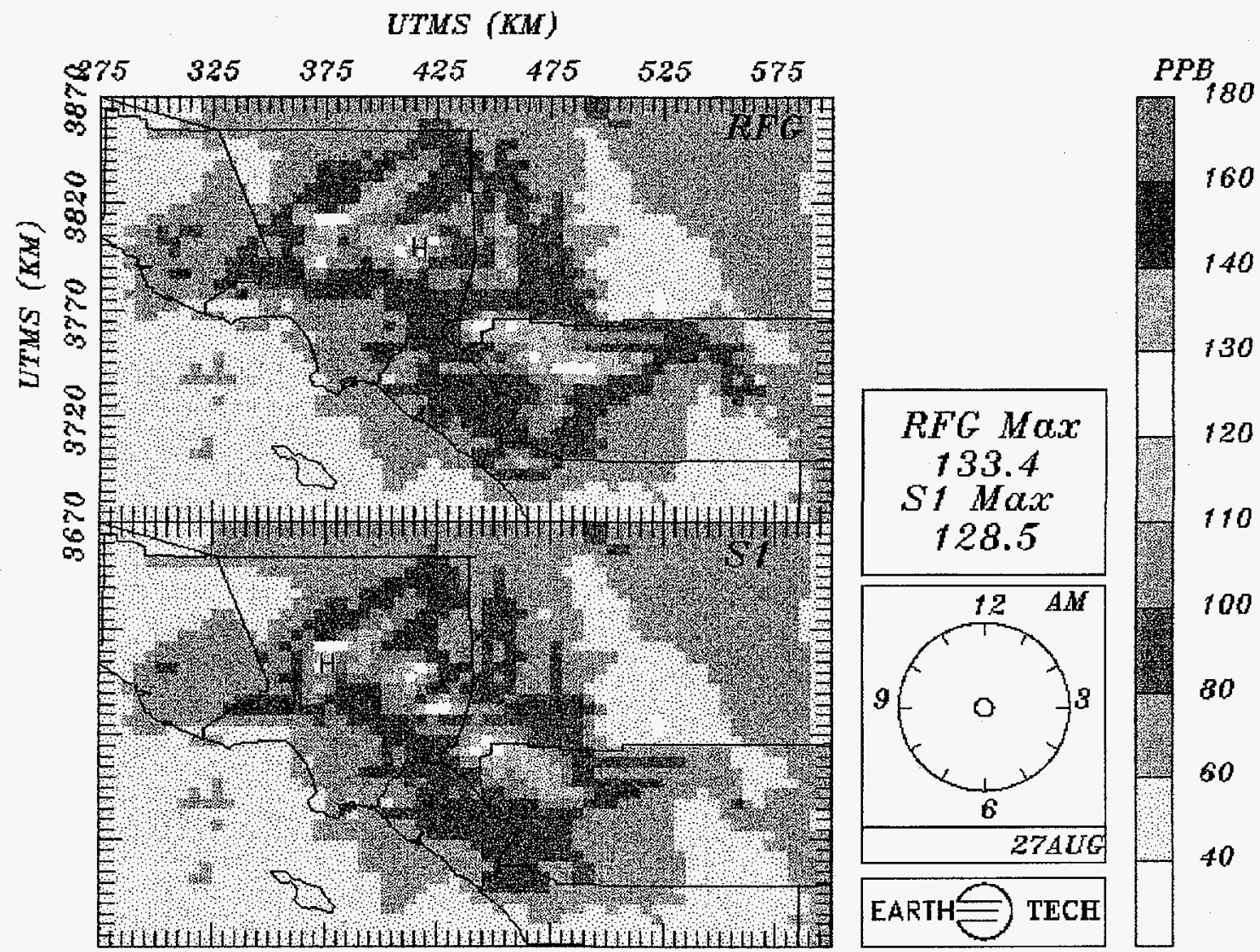

DAILY MAX SURFACE OZONE- UAM-IV 2007

145

Figure 6-5. Daily maximum 1-hour $\mathrm{O}_{3}$ concentrations with and without on-road motor vehicles for the RFG scenario for Los Angeles for 27 August for 2007. 


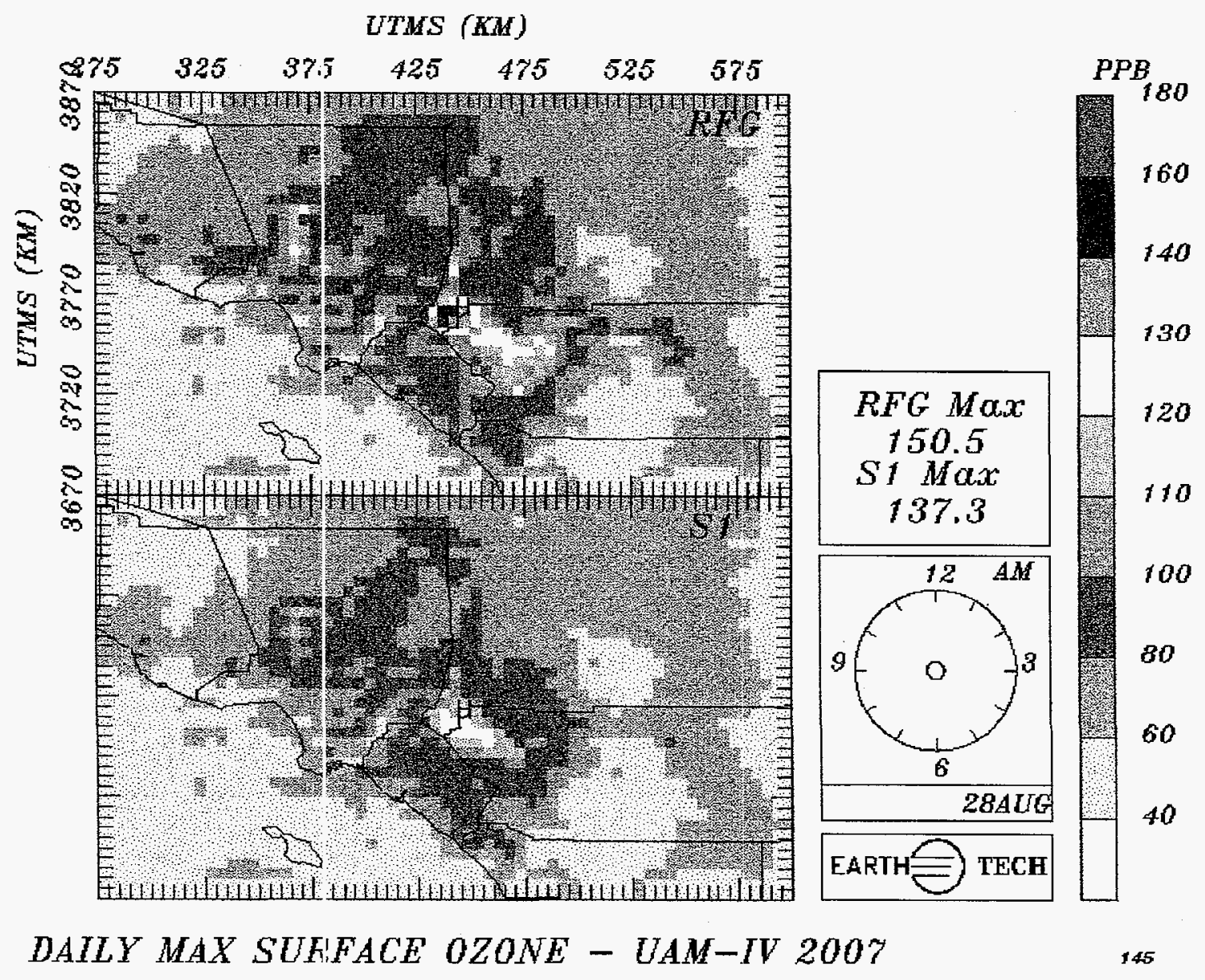

Figure 6-6. Daily maximum 1-hour $O_{3}$ concentrations with and without on-road motor vehicles for the RFG scenario for Los Angeles for 28 August for 2007. 


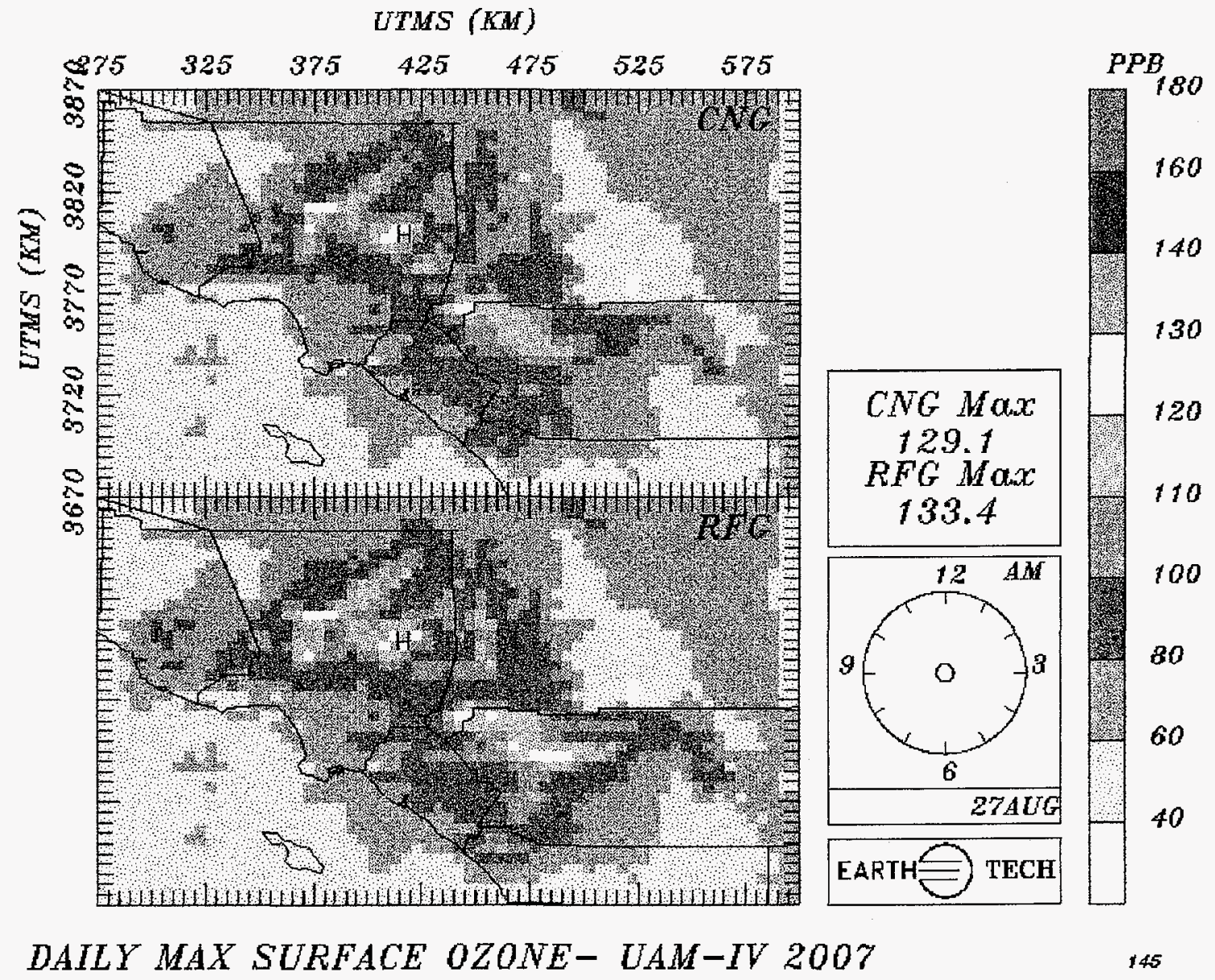

Figure 6-7. Daily maximum 1-hour $\mathrm{O}_{3}$ concentrations for RFG and CNG scenarios for Los Angeles for 27 August for 2007. 


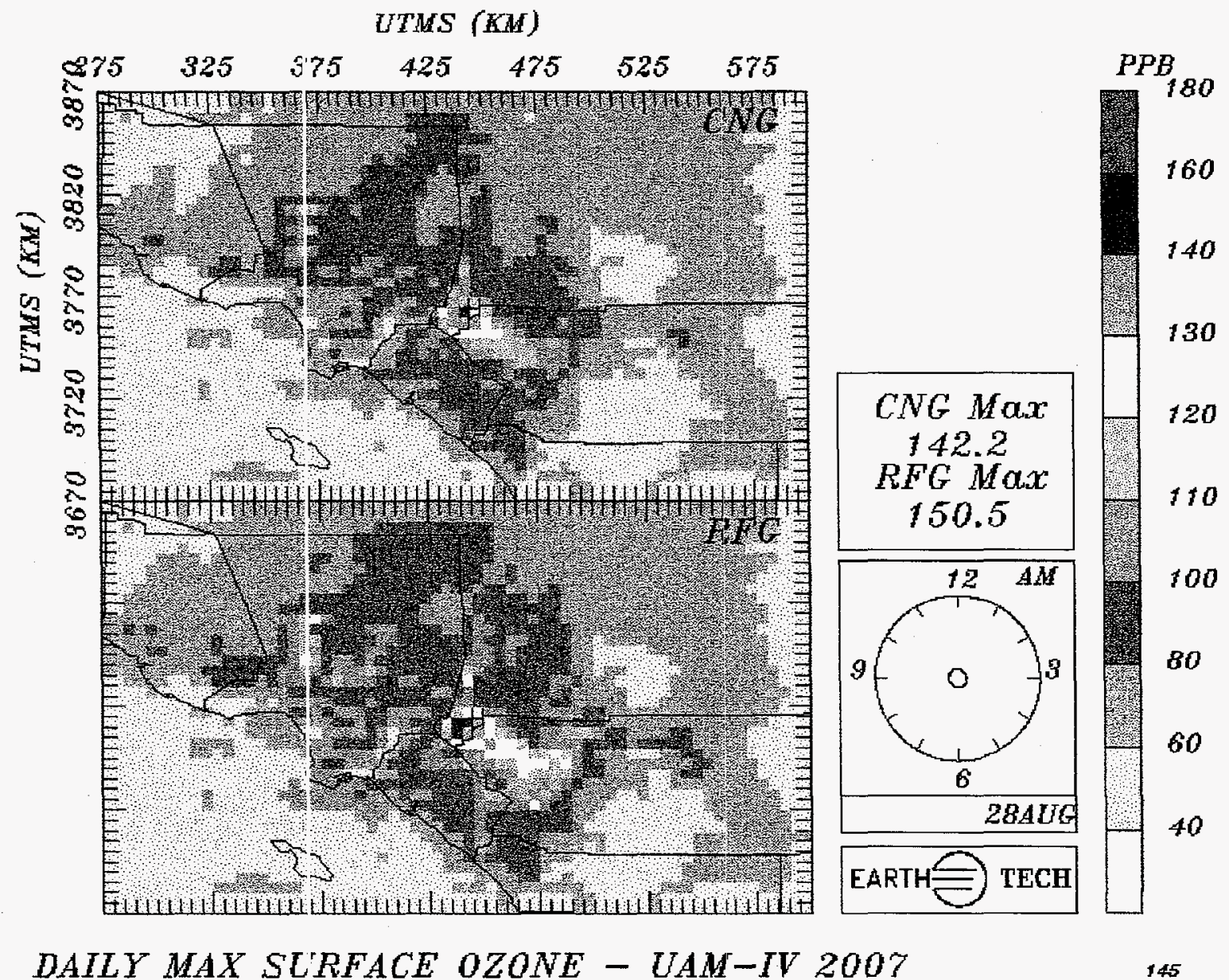

Figure 6-8. Daily maximum 1-hour $\mathrm{O}_{3}$ concentrations for RFG and CNG scenarios for Los Angeles for 28 August for 2007. 
The surface (UAM layer 1) daily maximum 1-hour VOC concentrations with RFG and CNG fueled vehicles are shown in Figure 6-9 for 28 August. For both scenarios, the peak VOC concentrations occur in the vicinity of Lennox and Long Beach with a secondary maximum in and around the city of Riverside. The maximum VOC concentration for the RFG scenario is only about $10 \%$ higher than for the CNG scenario, despite a factor of five difference in motor vehicle emissions.

The daily maximum 1-hour $\mathrm{NO}_{\mathrm{x}}$ concentrations for RFG and CNG scenarios are shown in Figure 6-10. Since the highest concentrations of $\mathrm{NO}_{\mathrm{x}}$ are caused by other source categories such as large point sources, domain-maximum values are the same for the two scenarios. Comparing the spatial patterns of $\mathrm{NO}_{\mathrm{x}}$ concentrations, the largest differences show up in major highway corridors such as the Riverside-Palm Springs corridor and the I-5 beltway between Anaheim and Irvine in Orange County.

\subsection{Intercomparisons of Maximum 8-Hour $\mathrm{O}_{3}$}

The patterns of daily maximum 8-hour average $\mathrm{O}_{3}$ concentrations on 28 August (Figure 6-11) are similar to those of daily maximum 1-hour concentrations in Figure 6-8. The peak 8-hour average $\mathrm{O}_{3}$ concentration due to RFG fueled vehicles is approximately $6 \mathrm{ppb}$ higher than that for CNG fueled vehicles (e.g., 112 ppb vs. $106 \mathrm{ppb}$ ). The maximum predicted concentrations for both fuel scenarios are located just to the west of Riverside. Riverside County has by far the highest 8-hour average concentrations. Statistics for peak 8-hour $\mathrm{O}_{3}$ predictions are summarized in Table 6-4. Differences between scenarios are very small for 27 August. For 28 August, the RFG scenario produced a $10 \%$ increase (10 ppb) in the domain maximum, relative to $\mathrm{S} 1$, while the $\mathrm{CNG}$ scenario produced a $4 \%$ increase. Domain-average 8 -hour concentrations increased by $0.2 \mathrm{ppb}$ for $\mathrm{CNG}$ and $0.6 \mathrm{ppb}$ for RFG.

\subsection{Intercomparisons of $\mathrm{O}_{3}$ and Toxic Exposures}

The SCAQMD study region fills the central portion of the modeling domain. Population exposure estimates were made using 1990 census data that were gridded on a $10 \times 10 \mathrm{~km}$ grid by the SCAQMD. The population density is displayed in Figure 6-12. The maximum population density is located in downtown Los Angeles. Several secondary maxima occur, including one in northern Orange County (i.e., Anaheim), one in the Rasceta-Burbank corridor, and the Pomona-Redlands-Riverside triangle. Smaller, isolated maxima occur in places like Palm Springs, Indio, and Victorville. The maximum population density is approximately one to two thousand people per square kilometer in Los Angeles proper. As can be noted from Figure 6-12, the SCAQMD data file used for the exposure assessment has numerous grid cells with zero population, which indicates a data base limitation for sparsely populated areas. 


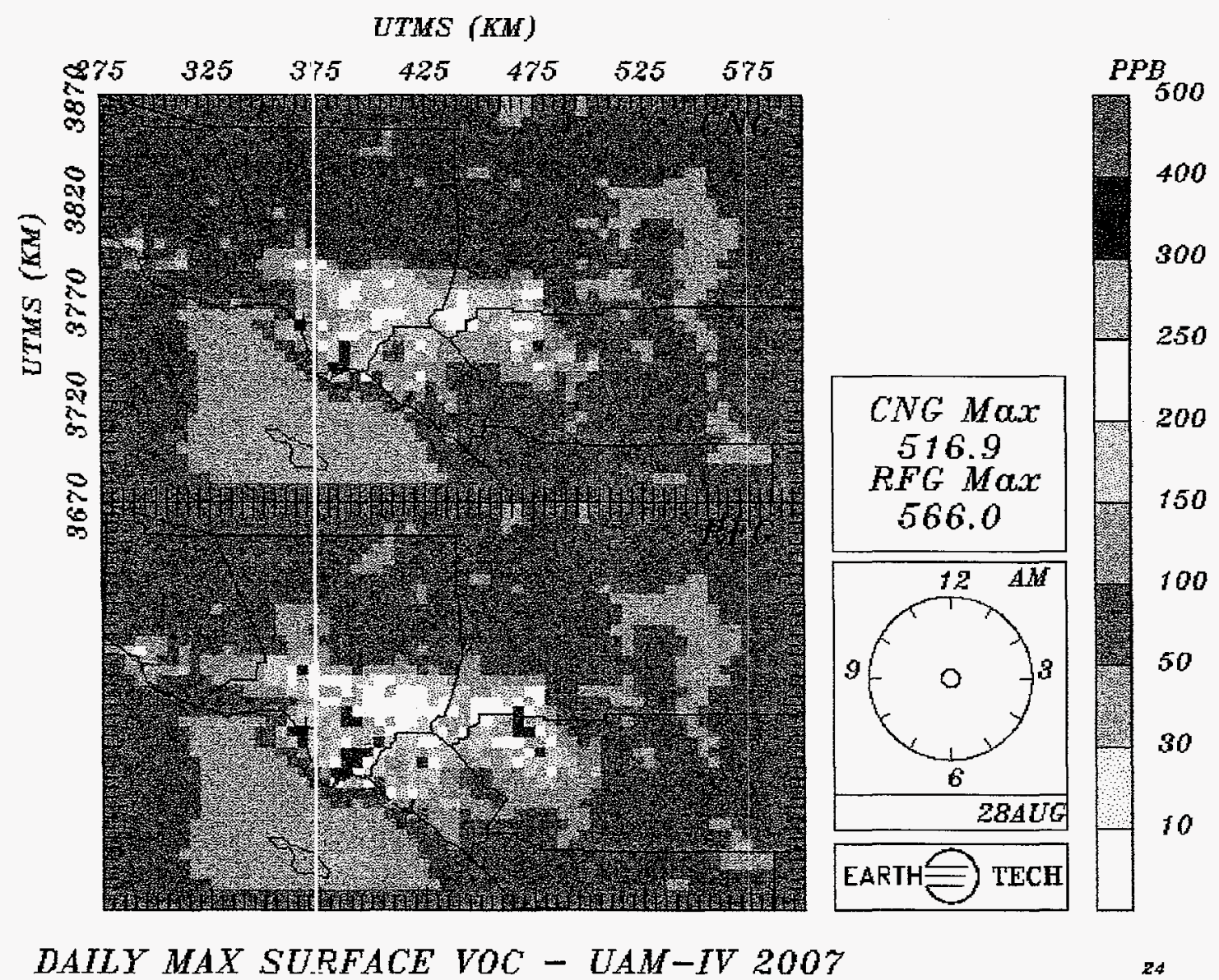

Figure 6-9. Daily maximun 1-hour VOC concentrations for RFG and CNG scenarios for Los Angeles for 28 August for 2007. 


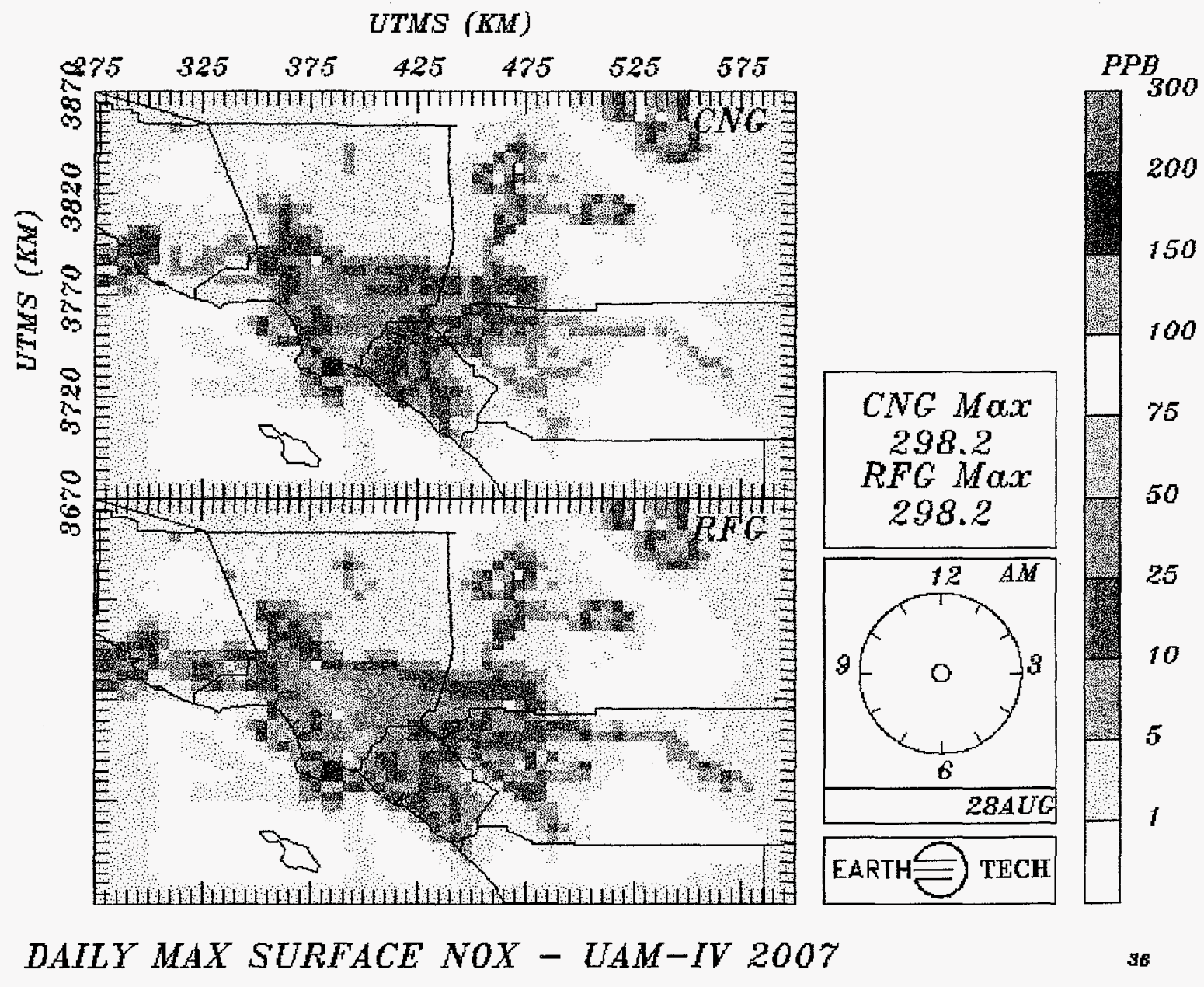

Figure 6-10. Daily maximum 1-hour NO concentrations for RFG and CNG scenarios for Los Angeles for 28 August for 2007. 


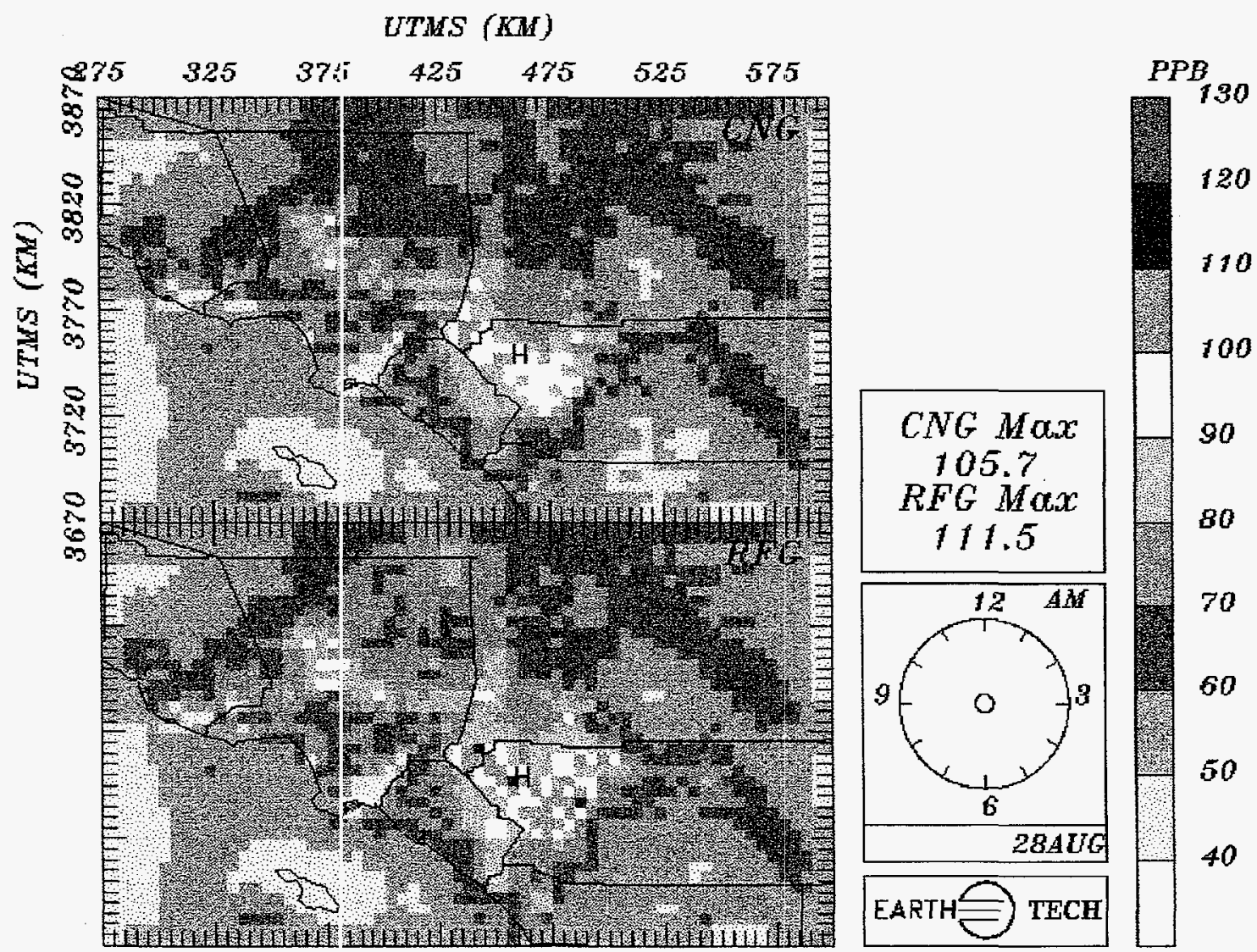

DAILY MAX B-FR SURFACE OZONE - UAM-IV 2007

19

Figure 6-11. Daily maximum 8-hour $\mathrm{O}_{3}$ concentration for RFG and CNG scenarios for Los Angeles for 28 August for 2007. 
SCAQMD 1990 POPULATION KILOPEOPLE PER GRID CELL

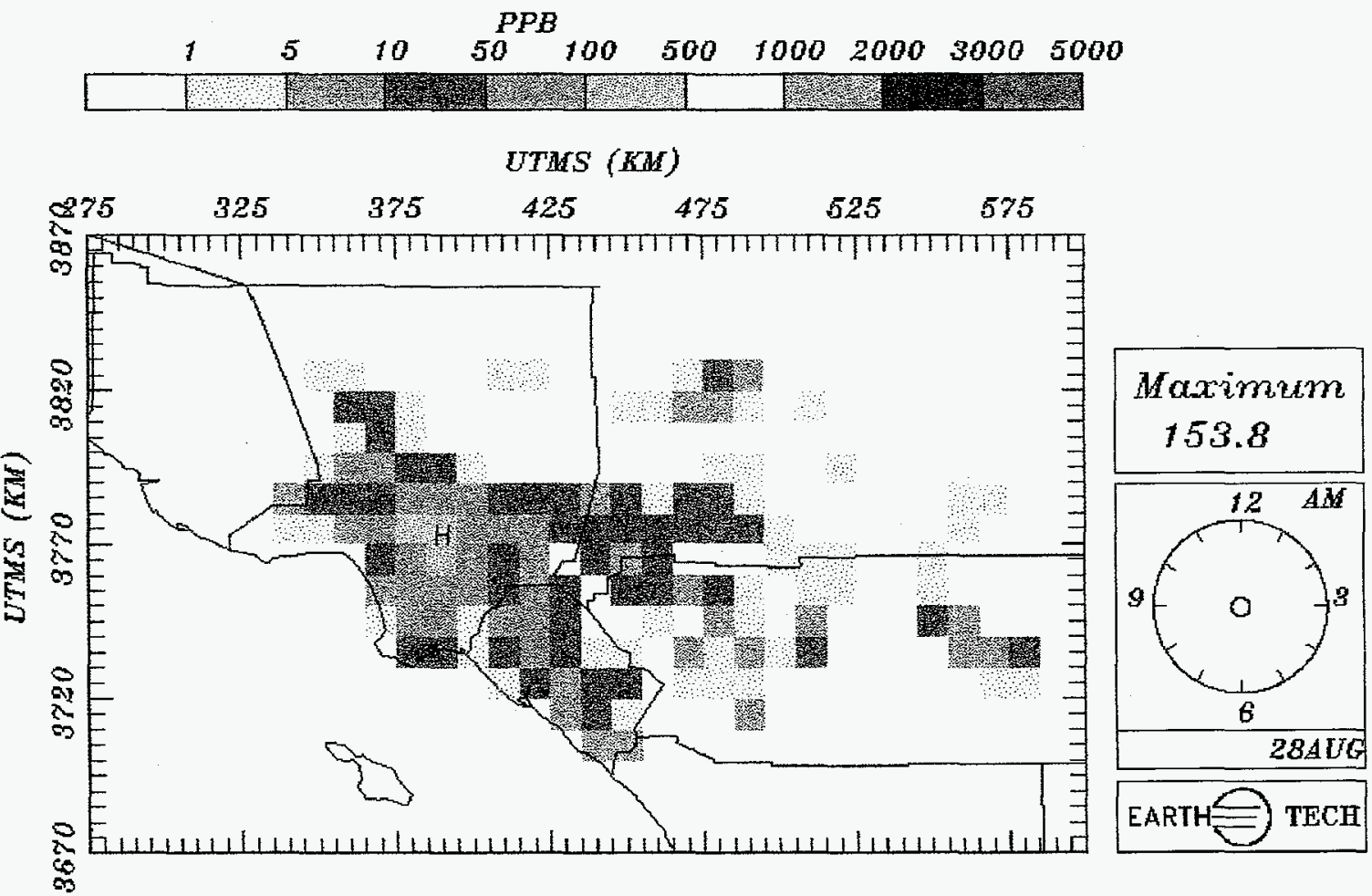

Figure 6-12. Population density in Los Angeles area for 1990. 
Table 6-4. Daily Maximum and Average 8-Hour $\mathrm{O}_{3}$ Concentrations in the Los Angeles Modeling Domain for 2007 (units are ppb)

\begin{tabular}{lccc}
\hline Statistic & Emission Scenario & 27 August & 28 August \\
\hline Maximum daily & S1 & 105 & 102 \\
Maximum daily & RFG & 106 & 112 \\
Maximum daily & CNG & 105 & 106 \\
Domain average & S1 & 45.2 & 45.8 \\
Domain average & RFG & 45.1 & 46.4 \\
Domain average & CNG & 45.2 & 46.0 \\
\hline
\end{tabular}

The exposure to $\mathrm{O}_{3}$ was estimated on a daily basis as the sum over all hours of the product of the hourly predicted $\mathrm{O}_{3}$ in a cell times the number of people in the grid cell. The domain-wide sum of exposure to $\mathrm{O}_{3}$ is summarized in Table 6-5. The units are parts per million times million people times hours. Two sets of exposure estimates are presinted, the first (No Threshold) representing all hourly concentrations in all grid cells, the second ( $80 \mathrm{fpb}$ Threshold) representing only those hours and cells with predicted concentrations exceeding $80 \mathrm{jpb}$. The No Threshold results are larger by more than a factor of 100 , reflecting the lower $\mathrm{O}_{3}$ predictions that occur in most cells for most hours. For both episode days, the No Threshold exposures are highest for the $\mathrm{S} 1$ scenario. At night, increased $\mathrm{NO}_{\mathrm{x}}$ emissions lead to lower predicted $\mathrm{O}_{3}$ concentrations, which may explain why the RFG scenario (with the highest $\mathrm{NO}_{x}$ emissions) produces the lowest exposure sstimates. With a concentration threshold of $80 \mathrm{ppb}$, exposure estimates a re consistent with peak $\mathrm{O}_{3}$ predicitions. The RFG scenario produces the highest exposure estimates for both episode days, and the S1 scentrio the lowest.

Table 6-5. Population Exposure to Predicted

Surface $\mathrm{O}_{3}$ Concentrations in Los Angeles for 2007 (units are $10^{6}$ people $x$ ppm-hours)

\begin{tabular}{ccccc}
\hline & \multicolumn{2}{c}{ No Threshold } & \multicolumn{2}{c}{80 ppb Threshold } \\
Emission Scenario & 27 August & 28 August & 27 August & 28August \\
\hline S1 & 13.6 & 14.5 & .026 & .048 \\
RFG & 12.4 & 13.8 & .057 & .114 \\
CNG & 13.2 & 14.2 & .036 & .078 \\
\hline
\end{tabular}

The pattern of $\mathrm{O}_{3}$ exposure (No Threshold) for the RFG and CNG fueled vehicle cases is illustrated in Figure 6-13 for 28 August when the largest overall exposures were predicted. The peak in the $\mathrm{O}_{3}$ exposure occurs 


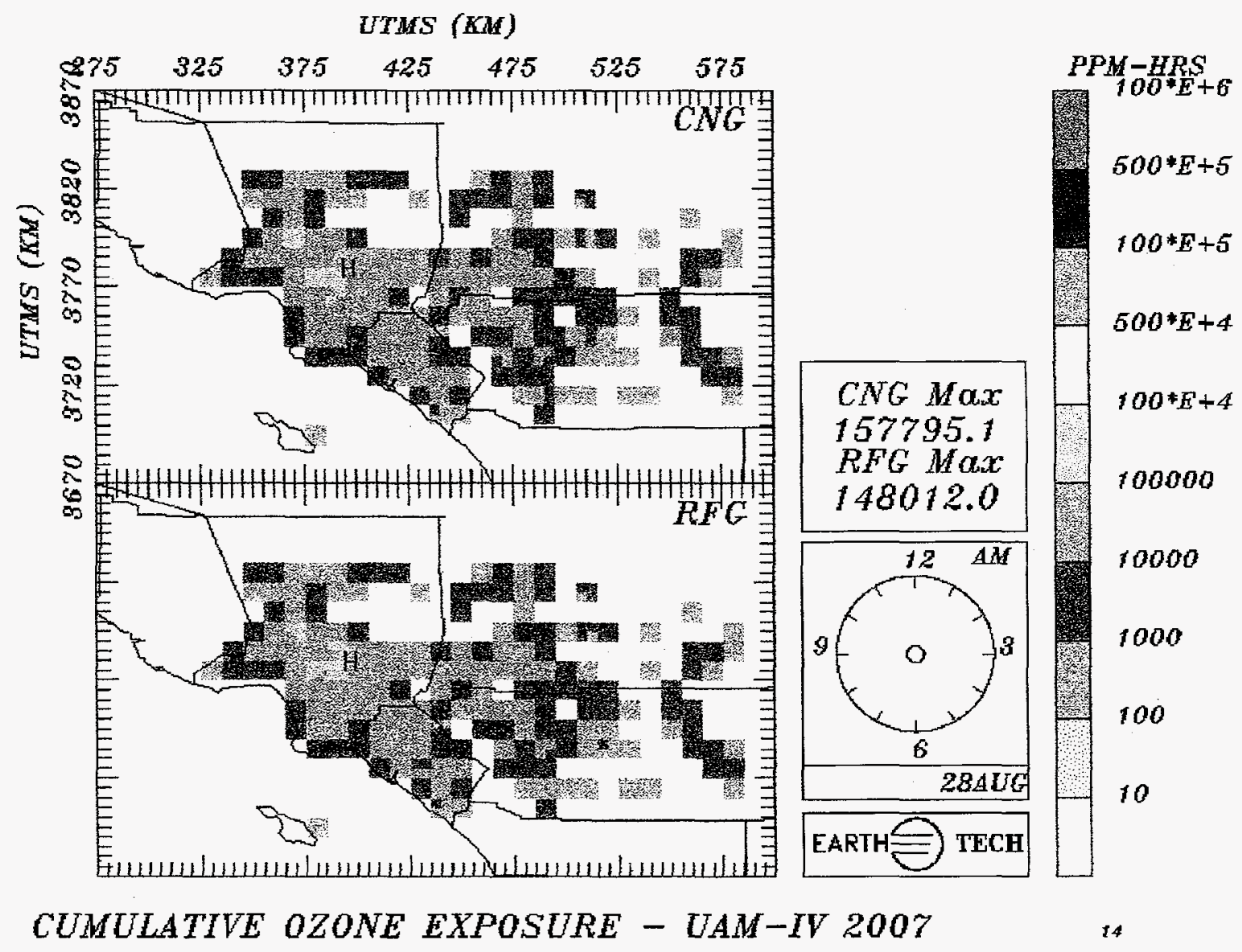

Figure 6-13. Cumulative $\mathrm{O}_{3}$ exposure for RFG and CNG scenarios for Los Angeles for 28 August for 2007. 
in the vicinity of downtown Los Angeles, which might be expected given the population density. The largest differences in $\mathrm{O}_{3}$ exposure occur in the Reseda-Burbank-Los Angeles corridor. The surface $\mathrm{NO}_{\mathrm{x}}$ concentrations in this corriclor are relatively large. The predicted $\mathrm{O}_{3}$ time series at Burbank in the base simulation (not shown) indicates that surface $\mathrm{O}_{3}$ concentrations fall very close to zero at night. The low night-time $\mathrm{O}_{3}$ and elevated $\mathrm{NO}_{x}$ concentrations suggest that the titration of $\mathrm{O}_{3}$ by $\mathrm{NO}$ (at night) is a key factor in the No Threshold exposure results.

The maximum daily 1-hour concentrations and the population exposure to the four toxic compounds (FORM, ACET, BENZ, and BUDI) are summarized in Table 6-6. Emissions of the two "ghost" species, $\mathrm{BENZ}$ and BUDI, were only assigned for motor vehicle sources. Concentration predictions for these two species are therefore based cnly on motor vehicle emissions, plus contributions from initial and boundary concentrations. The species FORM and ACET were assigned for all VOC emission sources, based on source emission profiles. Several observations can be made from this table including the following:

- $\quad$ Predicted FORM concentrations and population exposures are the largest of any of the toxic compounds.

- The largest concentrations and exposures occur on 28 August with the exception of the maximum ACET concentration.

- The largest predicted toxic concentrations and exposures occur for the RFG scenario.

- The CNG fueled velicle scenario and the unaffected source scenario are most similar in terms of the maximum predicted concentrations and exposures.

The cumulative FORM expc sure patterns for the RFG and CNG fueled vehicle cases are shown in Figure 6-14 for 28 August. Note that the units are ppb-people-hours. The figure indicates that the highest predicted exposure occurs in the vicinity of downtown Los Angeles. The exposures to FORM in the RFG scenario are most different from those for the CNG scenario in and around Los Angeles. The spatial pattern of population exposure to toxic compounds for the CNG scenario resembles the exposure pattern for the S1 scenario more closely than the RFG pattern.

\subsection{Relative $\mathrm{O}_{3}$ Formation Potential Analysis}

The individual chemical species included within VOC emissions do not all contribute equally to $\mathrm{O}_{3}$ formation. Since the chemical composition of VOC emissions from RFG and CNG fueled vehicles is quite different, a method of comparing VOC emissions on the basis of reactivity or ozone-forming potential would provide further insight regarding the environmental impact of AFVs. Several approaches for making this comparison were: considered in the protocol (Appendix B), including the maximum incremental reactivity (MIR) metric defined by Carter (1994). 
UTMS (KM)

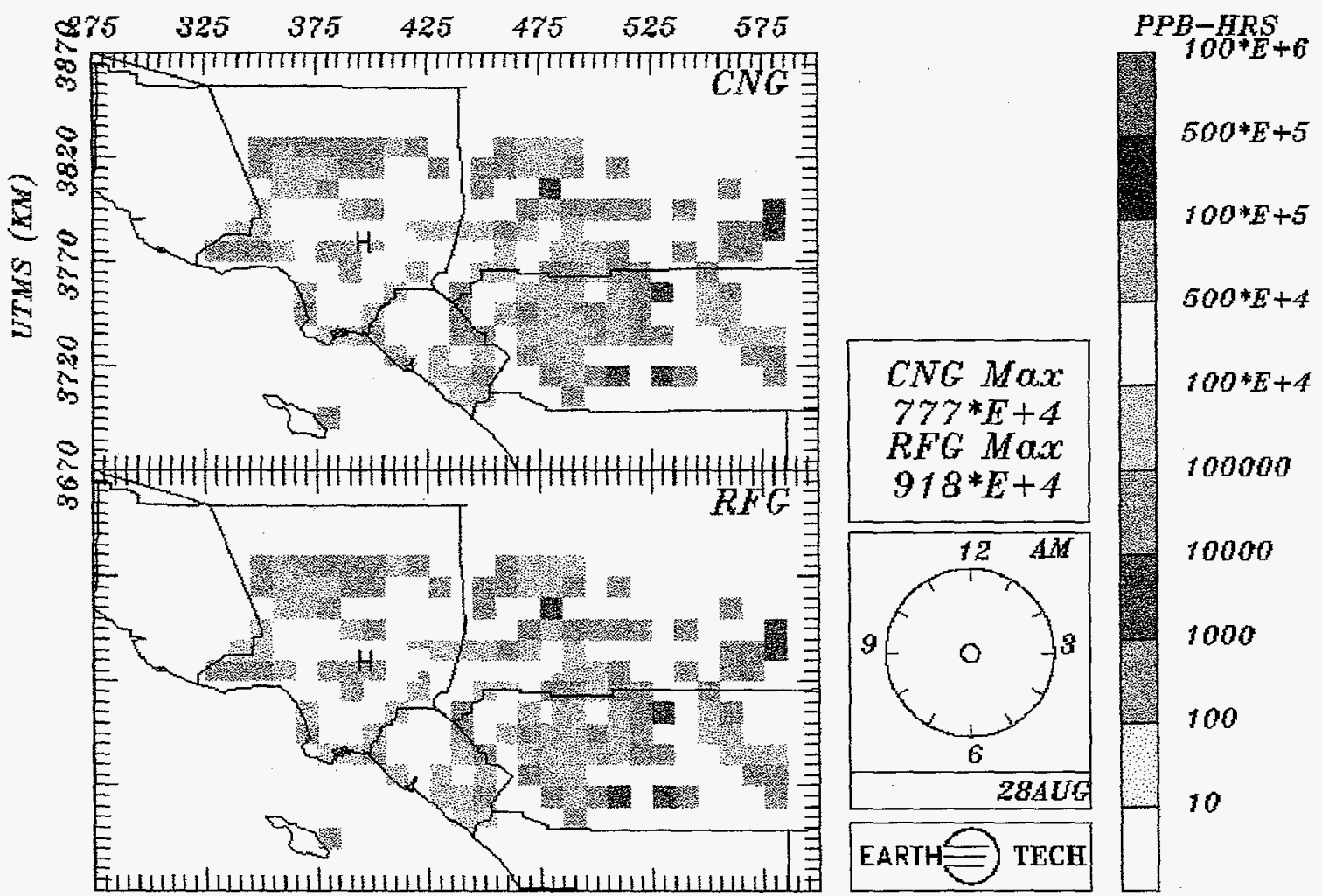

CUMULATIVE FORM EXPOSURE - UAM-IV 2007

GE

Figure 6-14. Cumulative FORM exposure for RFG and CNG scenarios for Los Angeles for 28 August for 2007. 
Table 6-6. Daily Maximum 1-Hour Concentrations and Domain-wide Cumulative Populations Exposures to Each of the Four Toxic Compounds

in Los Angeles Modeling Domain for 2007 (units are ppb-people-hours)

\begin{tabular}{lcccccc}
\hline Statistic & Date & Emission scenario & FORM & ACET & BENZ & BUDI \\
\hline Maximum daily 1-hour & 2.7 August & S1 & 16.0 & 4.20 & 1.28 & 0.25 \\
& & RFG & 16.3 & 5.40 & 2.00 & 0.27 \\
& & CNG & 16.0 & 4.20 & 1.28 & 0.25 \\
Cumulative exposure & 27 August & S1 & 1.13 & 0.565 & 0.138 & 0.0027 \\
& & RFG & 1.18 & 0.626 & 0.191 & 0.0055 \\
Maximum daily 1-hour & 28 August & CNG & 1.13 & 0.567 & 0.139 & 0.0030 \\
& & S1 & 16.4 & 4.00 & 1.20 & 0.25 \\
& & RFG & 16.8 & 5.40 & 2.00 & 0.25 \\
Cumulative exposure & 28 August & CNG & 16.5 & 4.10 & 1.30 & 0.25 \\
& & S1 & 0.876 & 0.531 & 0.135 & 0.0014 \\
& & RFG & 0.956 & 0.622 & 0.208 & 0.0038 \\
\hline
\end{tabular}

${ }^{1}$ No emissions of BUDI, BENI for S1 scenario

For this study, one would like to be able to calculate the ozone formation potential (ozone formed per unit emission) that would result from use of a given alternative fuel. Multiple model runs in which small emissions increments are applied independently to each CB-4 species that is emitted by use of a given fuel are made, and the resulting formation potentials are summed to yield the composite ozone formation potential of the fuel. However, there is a conflict between using a small enough emissions increment to maintain linearity in the resulting chemical calculations and using a large enough increment to produce a statistically detectable change in ozone concentration.

For this study, a method of establishing a statistically significant yet linearity-preserving emission increment for each specie was not available. The scope of the study did not allow development of either direct differentiation versions (e.g., ADIFOR - Bischof, 1994) or direct decoupled me thod versions (e.g., Yang et al., 1997) of UAM-IV to yield incremental emissions sensitivities. Also, this study involves a specific episode with specific space- and time-varying meteorological conditions and overall emissions, so using generic specie ozone formation potentials from the literature (e.g. Carter, 1995) and applying them on a weighted basis to the present emissions mix for RFG and CNG would introduce uncertainties.

This study used a compromise approach to examine ozone forming potentials of the alternative fuels. A single generic set of incremental runs by specie was done. The increments chosen represented the difference between the RFG ernissions case and the no-motor-vehiclescase, except for several species for which a larger increment was necessary to produce a significant response. The results were assumed to represent the average ozone formation potential for these individual species over the range of motor vehicle emissions spanning no vehicle; to the full RFG case. The emissions from the CNG case will fall within this range, and these average sjecies-specific ozone potentials can be weighted to produce a fuel-specific ozone formation potential for either RFG or CNG. Any proposed approach would be limited by the factors 
discussed above; this approach has the advantage that the specie-specific ozone formation potentials are appropriate for this set of episode conditions, domain, and emissions mix.

A series of nine simulations were conducted in which a single chemical species that is emitted by RFG vehicles was to the $S 1$ scenario. The simulations include eight organic species, plus $N_{\mathrm{x}}$ for comparison purposes. Table 6-7 lists the incremental species emissions ( $\triangle \mathrm{Qs})$. The emissions for FORM, ACET and ISOP were scaled upwards by factors of 10 or 100 in order to obtain a significant $\mathrm{O}_{3}$ response. The estimated peak $\mathrm{O}_{3}$ sensitivity and the $\mathrm{O}_{3}$ formation potential for each pollutant depend on the degree to which the $\mathrm{O}_{3}$ response can be linearly scaled.

The largest change in daily maximum ozone $\left(\Delta \mathrm{O}_{3}\right)$ was predicted in response to motor vehicle $\mathrm{NO}_{x}$ emissions. The negative sign indicates that an increase in $\mathrm{NO}_{x}$ emissions produced a decrease in predicted peak $\mathrm{O}_{3}$ for 28 August. The large response for $\mathrm{NO}_{x}$ reflects the large emission increment (197 tons/day). On an emissions-weightedbasis $\left(\Delta \mathrm{O}_{3} / \Delta \mathrm{Q}\right)$, the largest incremental $\mathrm{O}_{3}$ response is predicted for OLE. The smallest emissions-weighted responses are predicted for PAR and for TOL, which also has a predicted negative $\mathrm{O}_{3}$ response on 28 August.

These $\mathrm{O}_{3}$ sensitivities are similar to those reported by Bergin et al. (1995). The peak $\mathrm{O}_{3}$ at the surface reflects the competing effects of $\mathrm{NO}_{x}$ titration and radical scavenging and $\mathrm{O}_{3}$ production by increased efficiency of $\mathrm{NO}_{2}$ formation by radical chemistry. The negative sensitivity of $\mathrm{O}_{3}$ to TOL emissions is generally thought to occur under large VOC: $\mathrm{NO}_{x}$ ratios for which $\mathrm{O}_{3}$ formation is expected to be $\mathrm{NO}_{\mathrm{x}}{ }^{-}$ limited. On 28 August, the domain average VOC:NO ratio ranges from 15:1 to 20:1. In this range, Bergin et al. indicates TOL would have a negative sensitivity effect.

Table 6-7. $\mathrm{O}_{3}$ Sensitivities (ppb/ton) for Peak Maximum Daily $\mathrm{O}_{3}$ in Los Angeles on 28 August 1997

(unless noted otherwise, the $\Delta Q$ is the difference between $\mathrm{S} 1$ and RFG emissions scenarios)

\begin{tabular}{lccc}
\hline \multicolumn{1}{c}{ Species } & $\Delta O 3(\mathrm{ppb})$ & $\Delta \mathrm{Q}(\mathrm{TPD})$ & $\Delta 03 / \Delta \mathrm{O} \mathrm{ppb} /$ ton \\
\hline $\mathrm{NO}_{\mathrm{x}}$ & -5.21 & 197.0 & -0.026 \\
PAR & 1.29 & 92.0 & 0.014 \\
TOL & -0.33 & 25.0 & -0.013 \\
XYL & 0.90 & 26.5 & 0.034 \\
FORM & 1.32 & $7.1^{*}$ & 0.187 \\
ACET & 2.32 & $18.5^{* *}$ & 0.125 \\
OLE & 1.20 & 5.5 & 0.217 \\
ETH & 0.48 & 3.7 & 0.130 \\
ISOP & 2.36 & $15.0^{* *}$ & 0.157 \\
\hline
\end{tabular}

$*=\times 10$ actual

$*^{*}=\times 100$ actual 
Peak $\mathrm{O}_{3}$ sensitivity is sometimes not a good indicator of $\mathrm{O}_{3}$ formation potential since the meteorological component of the $\mathrm{O}_{3}$ buildup cannot be separated from the emissions. An approach that is less dependent on the source characteristicsand on the dispersion pattern is to estimate how many tons of $\mathrm{O}_{3}$ were formed or destroyed per ton of a specific chemical emitted over the entire domain. The net $\mathrm{O}_{3}$ production by species between daily maximums was also estimated for the entire Los Angeles modeling domain for August 28, based on the sensitivity runs described above. The resulting estimates of $\mathrm{O}_{3}$ formation potential in terms of tons of $\mathrm{O}_{3}$ per ton of emissions are summarized in Table 6-8.

Table 6-8 also presents VOC reactivity weights that are normalized by the sum of all the VOC sensitivities. Any VOC emission source can be weighted on the basis of reactivity using the weights presented in Table 6-8. Note that of all the VOCs, the PARs, while contributing the largest mass emissions, are a ssigned the smallest weighting factor. Also, fuel that is rich in TOL is likely to produce less $\mathrm{O}_{3}$ than one with less TOL. 
Table 6-8. $\mathrm{O}_{3}$ Formation Potentials (ton- $\mathrm{O}_{3}$ /ton- $\mathrm{Q}$ ) Over the Entire Modeling Domain in Los Angeles on 28 August 2007

\begin{tabular}{lcccc}
\hline Species & $\Delta M^{\text {a }}$ (Tons) & $\Delta Q$ (TPD) & $\Delta M / \Delta Q$ (ton/ton) & $\begin{array}{c}\text { Normalized VOC } \\
\text { Reactivity Weight }\end{array}$ \\
\hline NO $_{\times}$ & 204 & 197.0 & 1.04 & $N A$ \\
PAR & 7.7 & 92.0 & 0.083 & 0.010 \\
TOL & -7.4 & 25.0 & -0.296 & -0.038 \\
XYL & 6.3 & 26.5 & 0.238 & 0.030 \\
FORM & 14.2 & $7.1^{*}$ & 2.00 & 0.254 \\
ALD2 & 27.7 & $18.5^{* *}$ & 1.50 & 0.191 \\
OLE & 14.0 & 5.5 & 2.55 & 0.323 \\
ETH & 1.2 & 3.7 & 0.324 & 0.041 \\
ISOP & 22.2 & $15.0^{* *}$ & 1.48 & 0.188 \\
\hline
\end{tabular}

a Cumulative Mass change from hour beginning 2300 on 27 August through 2400 on 28 August.

By weighting the emissions by reactivity using Table 6-8, we can compare the $\mathrm{O}_{3}$ formation potential for the CNG scenario with the RFG scenario. The results of such reactivity weighting are summarized in Table 6-9. An incremental increase of 6.2 tons of VOC from CNG fuel vehicles translates into a 0.14 ton reactivity weighted increment. The RFG fueled vehicle emission difference is greater. A 153 ton increase translates to a 3 ton reactivity weighted increment. On a reactivity-weighted basis, the VOC emissions increment for RFG fuel vehicles is 21 times the increment for CNG vehicles ( 3 versus 0.14 tons), while the VOC mass emissions (unweighted) from RFG are 25 times the CNG emissions (154 versus 6.2 tons). The small difference is attributable primarily to a larger TOL fraction in the RFG emissions.

\subsection{Mass Budget Analysis}

The mass flux budget provides information regarding the role of initial and boundary conditions and the influence of different sources and sinks of a given chemical. It can also indicate whether a chemical is highly reactive with a short lifetime. The overall 2-day cumulative mass exchanges for selected species into and out of the modeling domain are summarized in Table 6-10.

For $\mathrm{O}_{3}$, the net chemical production over two days is roughly equal to the domain-wide total mass. The net increase in $\mathrm{O}_{3}$ mass is only $7 \%$ of the total mass present at the end of the episode. The export of $\mathrm{O}_{3}$ through the side boundaries equals about half of the chemical production of $\mathrm{O}_{3}$ and is much larger than the deposition flux. This large export, as was shown earlier, is dominated by outflow through the eastern boundary of the modeling domain. 
Table 6-9. Reactivity-Weighted Daily VOC Emissions

Increment for Alternative Fuel Scenarios, Los Angeles, 2007 (units are tons/day)

\begin{tabular}{lccccc}
\hline Species & \multicolumn{2}{c}{ RFG Fueled Vehicles } & & \multicolumn{2}{c}{ CNG Fueled Vehicles } \\
\cline { 3 - 5 } & $\begin{array}{c}\text { Erission } \\
\text { (tons) }\end{array}$ & $\begin{array}{c}\text { Reactivity } \\
\text { weighted emission } \\
\text { (tons) }\end{array}$ & $\begin{array}{c}\text { Emissions } \\
\text { (tons) }\end{array}$ & $\begin{array}{c}\text { Reactivity weighted } \\
\text { emission } \\
\text { (tons) }\end{array}$ \\
\hline PAR & 92 & 0.92 & 4.6 & 0.046 \\
OLE & 5.5 & 1.78 & 0.14 & 0.045 \\
ETH & 3.7 & 0.15 & 0.51 & 0.021 \\
TOL & 25 & -0.95 & 0.49 & -0.019 \\
XYL & 27 & 0.80 & 0.37 & 0.011 \\
FORM & 0.71 & 0.18 & 0.09 & 0.023 \\
ACET & $(1.19$ & 0.04 & 0.04 & 0.008 \\
ISOP & $(1.15$ & 0.03 & 0.0 & 0.00 \\
Total & 154 & 2.95 & 6.2 & 0.14 \\
\hline
\end{tabular}

Table 6-10. A Summary of Cumulative Domain-wide Mass Exchanges (Fluxes, Sources, Sinks) for Selectel Chemicals Over the Two-Day Period 27-28 August 2007 (units are tons)

\begin{tabular}{llccccccc}
\hline Species & Run & Net & $\begin{array}{c}\text { Top } \\
\text { flux }\end{array}$ & $\begin{array}{c}\text { Side } \\
\text { Flux }\end{array}$ & Deposition & Emission & Chemistry & $\begin{array}{c}\text { Total } \\
\text { Mass }^{\text {a }}\end{array}$ \\
\hline O3 & S1 & 913 & -3290 & -5490 & -2140 & 0 & 11800 & 13400 \\
NO & S1 & -103 & 567 & 823 & -94 & 677 & -2080 & 199 \\
VOC & S1 & -1360 & 777 & 2110 & 0 & 1040 & -5290 & 4330 \\
BENZ & S1 & 5.5 & -18 & 10 & 0 & 16 & -2 & 137 \\
BENZ & RFG & 15 & -21.7 & 8.4 & 0 & 31.4 & -2.3 & 146 \\
FORM & S1 & -107 & 165 & 330 & 0 & 6.6 & -609 & 296 \\
\hline
\end{tabular}

a The total mass is rounded to three significant figures and is the domain-wide total at midnight between 27 and 28 August.

Relatively little $\mathrm{NO}_{\mathrm{x}}$ mass is stored in the atmosphere, resulting in low predicted $\mathrm{NO}_{\mathrm{x}}$ concentrations in rural regions and aloft. The fluxes are several times larger than the typical total mass, suggesting that the turnover time of $\mathrm{NO}_{\mathrm{x}}$ within the domain is significantly less than a day. The total $\mathrm{NO}_{\mathrm{x}}$ mass is very responsive to the chemistry and fluxes through the boundaries. Over the course of the two-day episode, the total mass decreased by 50 percent. 
The chemical destruction of VOC is of the same magnitude as the domain-total VOC mass. The combined fluxes of VOC through the top and lateral boundaries are approximately three times larger than the emissions, suggesting that unless the source region is very localized, the boundary conditions may affect the $\mathrm{O}_{3}$ response to $\mathrm{VOC}$ emission control strategies.

BENZ is fairly nonreactive with only $1 \%$ of the total mass of BENZ reacting over the course of the twoday episode. The BENZ emissions are of the same approximate size as the lateral and top boundary fluxes. The total mass of BENZ is over a factor of five larger than the source term. Under the case of the RFG fueled vehicles, the emission rate is several times larger than the boundary imports and exports. This difference suggests that the boundary conditions are not so large as to dominate over the response of the model to increased RFG BENZ emissions.

The FORM emissions are many times smaller than the total mass and the lateral fluxes, indicating that changing the FORM source term is unlikely to have much of an effect on human exposure to FORM throughout the modeling domain. The chemistry is rather reactive, with the rate of destruction exceeding the total rate of mass import. The net loss over two days is about a third of the total mass, and in this respect FORM behaves like the overall VOC. 


\subsection{Analysis of Future-Year Modeling Results for Atlanta}

Three future-year UAM-IV model simulations for Atlanta were made for 2007. The 1987 base-year emissions were projected to 2007 through application of appropriate growth and control factors. Such projections become rather uncertain after a few years due to the vagaries of the economy, unforeseen shifts in demography, and the complex interplay between evolving emission control programs. The use of AFVs will result not only in changes in the on-road mobile emissions component, but also in emission changes associated with fuel processing and distribution.

Three emission inventories were prepared for the future year modeling. The first inventory contained all point and area source emissions in the Atlanta area except those associated with on-road vehicles, plus gasoline fuel distribution and marketing. In addition, it contained emissions for all diesel vehicles, both on- and off-road, and emissions for all heavy-duty gasoline-fueled motor vehicles. This emissions scenario was called $\mathrm{S} 1$, and when modeled, provides an indication of what fraction of the surface $\mathrm{O}_{3}$ concentrations are due to sources other than light- and medium-duty gas vehicles. The sources comprising the S1 scenario were called "unaffected sources" since they were not involved in or affected by motor vehicle fuel substitution.

The second inventory consisted of emissions from all light- and medium-duty gasoline on-road motor vehicles. In addition, it included emissions from those point and area sources associated with gasoline-fuel distribution and marketing. These on-road emissions, when added to the $S 1$ inventory emissions, produced the 2007 LRVP scenario ${ }^{1}$. This scenario was used to estimate the future year response of $\mathrm{O}_{3}$ due to an inventory containing a gasoline fuel motor vehicle fleet. In a similar manner, an emissions scenario was developed that assumed all light- and medium-duty gasoline vehicles were instead dedicated to use of CNG. This inventory, when added to the S1 inventory, produced the CNG scenario inventory.

As indicated in the introduction, a major goal of this study is to quantify the degree to which the use of LRVP gasoline and CNG fuel vehicles may affect ambient concentrations of and population exposures to $\mathrm{O}_{3}$ and toxics during a severe $\mathrm{O}_{3}$ episode. In this section, we present and analyze the results of the three UAM simulations where the changes in model inputs reflect the effects of alternative vehicle fuels.

\subsection{Surface Emissions Inventory Description}

Our focus is on surface emission sources of VOCs and $\mathrm{NO}_{x}$, the major precursors of $\mathrm{O}_{3}$. Of secondary interest are the emissions of the toxic compounds FORM, ACET, BENZ, and BUDI. The surface emissions inventory consists of four major components: biogenics, low-level points, off-road area emissions (fixed plus stationary), and on-road mobile emissions. We summarize the VOC and $\mathrm{NO}_{\mathrm{x}}$ emissions components for each of the three emissions inventories in Table 7-1. The daily tonnages of emissions for $\mathrm{NO}_{\mathrm{x}}$ are expressed as $\mathrm{NO}_{2}$ equivalents and the VOCs are expressed in terms of $\mathrm{CH}_{4}$ equivalent mass for only the primary CBM-IV species (e.g., no BENZ or BUDI). For comparison, elevated point source emissions are also contained in Table 7-1.

\footnotetext{
${ }^{1}$ Emissions for this scenario are based on low RVP gasoline.
} 
Table 7-1. Estimated Emissions in Atlanta Modeling Domain for 2007 Emission Scenarios

\begin{tabular}{|c|c|c|c|c|}
\hline \multirow[b]{2}{*}{ Pollutant } & \multirow[b]{2}{*}{ Source Type } & \multirow{2}{*}{$\begin{array}{c}\text { s1 } \\
\text { Unaffected } \\
\text { Sources } \\
\text { (tons/day) }\end{array}$} & \multicolumn{2}{|c|}{$\begin{array}{l}\text { Alternative Fuel Scenario } \\
\text { Incremental Emissions (tons/day) }\end{array}$} \\
\hline & & & LRVP & CNG \\
\hline \multirow[t]{6}{*}{ Voc } & Motor Velicle & 39 & 209 & 2.5 \\
\hline & Area & 365 & 11 & 1.1 \\
\hline & Low Leve Point & 55 & 6.0 & 0.6 \\
\hline & Elevated F'oint & 24 & 0.2 & 0 \\
\hline & Biogenics & 1,010 & 0 & 0 \\
\hline & Total VOC: & 1,500 & 230 & 4.2 \\
\hline \multirow[t]{6}{*}{$\mathrm{NO}_{\mathrm{x}}$} & Motor Vehicle & 122 & 364 & 55 \\
\hline & Area & 189 & 0 & 0 \\
\hline & Low Level Point & 0.2 & 0 & 0 \\
\hline & Elevated Foint & 380 & 0 & 0 \\
\hline & Biogenics & 28 & 0 & 0 \\
\hline & Total $\mathrm{NO}_{x}^{\mathrm{a}}$ & 720 & 360 & 55 \\
\hline
\end{tabular}

a Totals are rounded to two or fewer significant figures and do not include $\mathrm{CO}$ and $\mathrm{CH}_{4}$.

The emissions totals in Table 7-1 indicate that biogenic emissions in Atlanta constitute a major fraction of the total VOC emission budget. These biogenic emissions are used directly as obtained from the DNR. It should also be noted that (unlike the Los Angeles inventory) the Atlanta biogenic emissions include a small soil $\mathrm{NO}_{\mathrm{x}}$ component. For all emission scenarios, the largest VOC source categories are biogenics and area sources. For $\mathrm{NO}_{\mathrm{x}}$, elevated point sources account for $53 \%$ of $\mathrm{S} 1$ scenario emissions and $49 \%$ of CNG (plus S1) scenario emissions. For the LRVP scenario, the motor vehicle source category has the largest $\mathrm{NO}_{\mathrm{x}}$ emissions (45\%). The CNG fuel vehicle emissions contribute minimal VOCs; their contribution to $\mathrm{NO}_{x}$ emissions is only $15 \%$ of the $\mathrm{NO}_{x}$ emissions from LRVP gasoline fuel vehicles.

The spatial distribution of surface emissions of $\mathrm{NO}_{\mathrm{x}}$ and VOC for the $\mathrm{S} 1$ inventory is shown in Figure 7-1. The $\mathrm{NO}_{\mathrm{x}}$ emissions pattern indicates that Atlanta is a rather compact, well defined island of $\mathrm{NO}_{\mathrm{x}}$ emissions. The major highways appear as spokes from the central core. The largest $\mathrm{NO}_{\mathrm{x}}$ emissions occur near each of the three airports in the region. The VOC emissions indicate the dominance of the biogenic emissions. The density of emissions in the urban core is roughly a factor of four larger than the surrounding rural areas. The peak $\mathrm{NO}_{x}$ emission :ate per cell is smaller than that for VOCs (6.0 vs. 9.6 tons per day), and the total tonnage emitted per dzy is four times larger for VOCs than for (non-elevated) $\mathrm{NO}_{\mathrm{x}}$. 


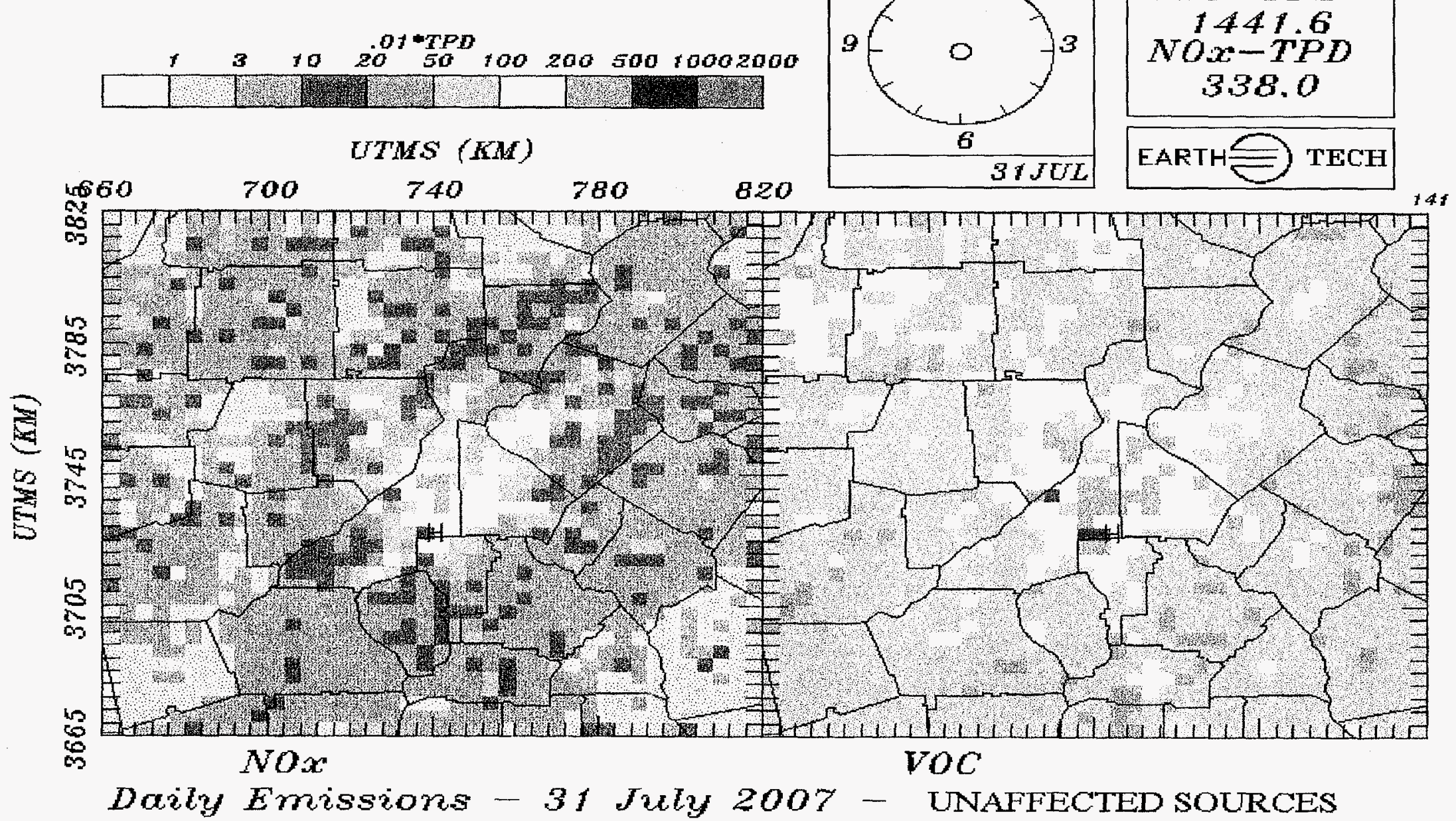

Figure 7-1. Daily Atlanta VOC and $\mathrm{NO}_{\mathrm{x}}$ emissions density plot for 2007 with on-road light- and medium-duty vehicle emissions removed. 
The diurnal pattern of domain-total $\mathrm{NO}_{\mathrm{x}}$ and VOC by major component for the $\mathrm{S} 1$ inventory is shown in Figure 7-2. Diesel and gasoline (heavy truck) vehicle emissions peak around 0700 local standard time (LST) in the morning and again around 1600 LST in the evening. Biogenic VOC emissions appear to peak around 1500 LST when the higiest temperatures of the day occur. Low-level point source VOCs show an activity profile that resembles a square wave signal between 0900 and $1800 \mathrm{LST}$, corresponding to the work day.

The speciation of the LRVP gasoline scenario on-road mobile emissions is presented in Table 7-2. This table shows several interesting features, including low FORM emissions. With standard gasoline, one expects on the order of $2 \%$ of VOC emissions to be FORM. For the gasoline scenario, FORM and ACET together represent only $1 \%$ o: total emissions. Aromatic compounds (TOL and XYL) or the toxic compound BENZ represent, after PAR, the second largest source of organic carbon.

Figure 7-3 shows the spatial patterns of daily VOC emissions from gasoline and CNG fuel scenarios. The differences between the scenarios are dwarfed by the large biogenic VOC emissions. The highway corridors only begin to show up for the gasoline scenario. Emission differences are also evident in the Atlanta urban core and to the northwest (Marietta area). The CNG VOC emissions spatial pattern is essentially identical to Scenario S1.

Table 7-2. Speciation of VOC Emissions Increment for LRVP Gasoline Scenario for Atlanta, 2007

\begin{tabular}{cc}
\hline CBM-IV Speries & Emissions (tons per day, as $\mathrm{CH}_{4}$ equivalents) \\
\hline PAR & 130 \\
XYL & 29 \\
TOL & 34 \\
BENZ & 11 \\
OLE & 12 \\
ETH & 11 \\
FORM & 1.5 \\
ACET & 0.90 \\
HALD & .063 \\
BUDI & 0.58 \\
\hline
\end{tabular}

Figure 7-4 illustrates the spatial pattern of daily low-level $\mathrm{NO}_{\mathrm{x}}$ emissions for the two fuel scenarios. The $\mathrm{NO}_{\mathrm{x}}$ emissions peak in the dorvntown Atlanta area. The spatiall pattern for the LRVP scenario clearly shows highway corridors bracketing the downtown urban maximum. The grid-cell maximum and domainwide daily total emission rates show that $\mathrm{NO}_{\mathrm{x}}$ from gasoline fuel vehicles is much greater than that for the CNG fuel scenario (8.9 TPD vs. 6.5 TPD and 700 vs. 390 TPD, respectively). 


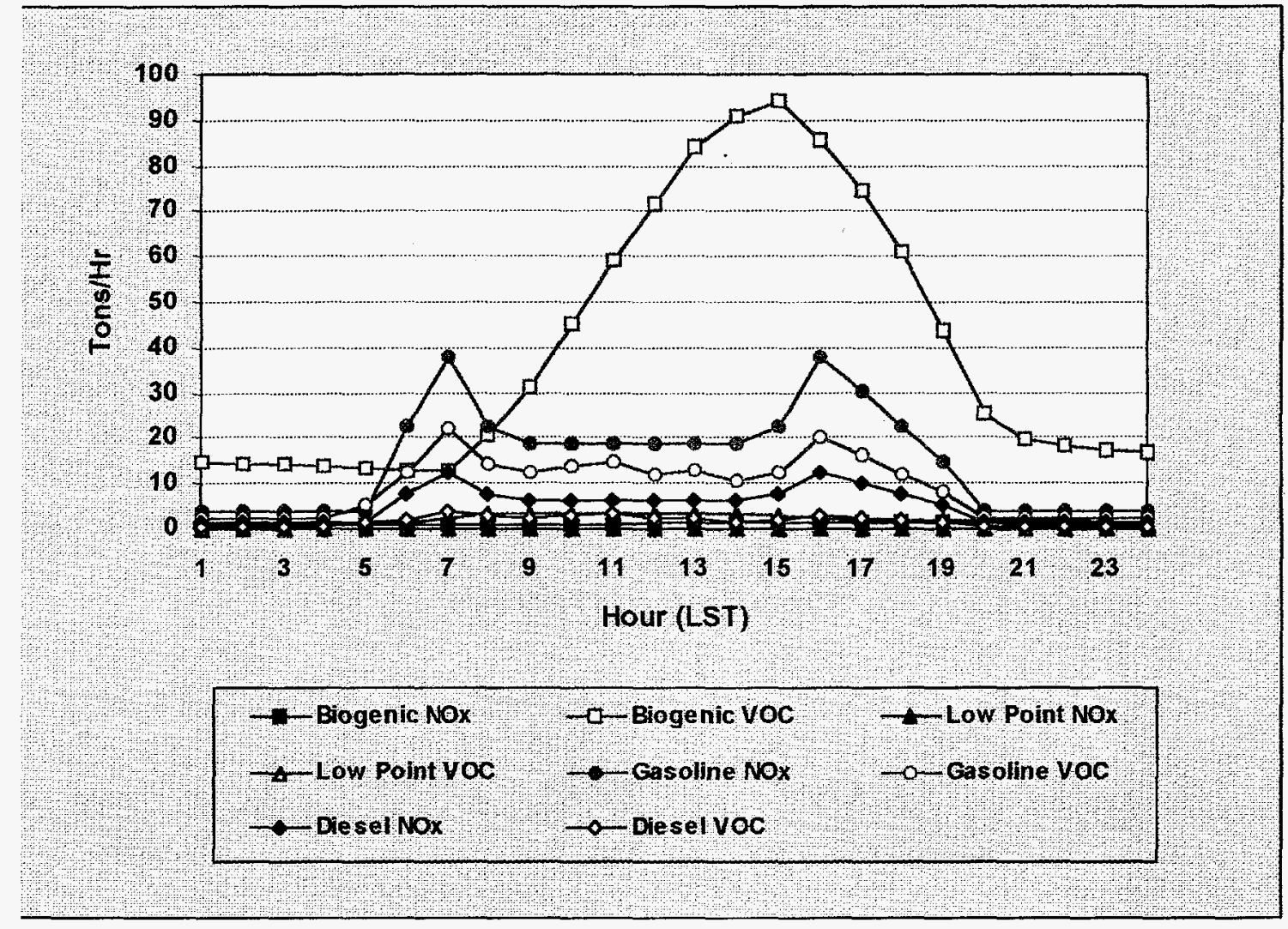

Figure 7-2. Diurnal trend in $\mathrm{NO}_{\mathrm{x}}$ and $\mathrm{VOC}$ emissions for Atlanta by emission category for 2007. 


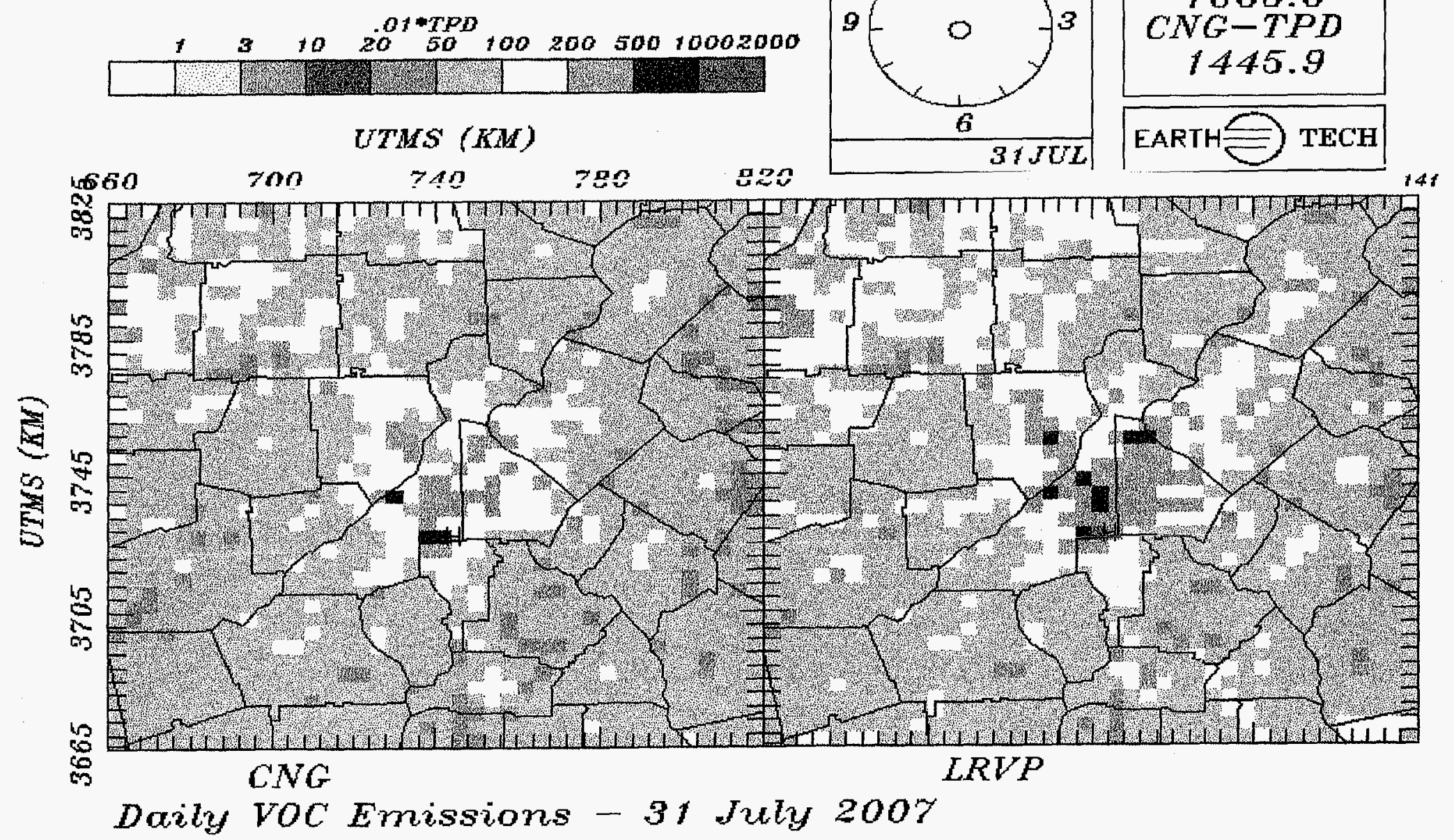

Figure 7-3. Spatial pattern of daily VOC emissions in Atlanta for 31 July for 2007 for CNG and LRVP scenarios. 


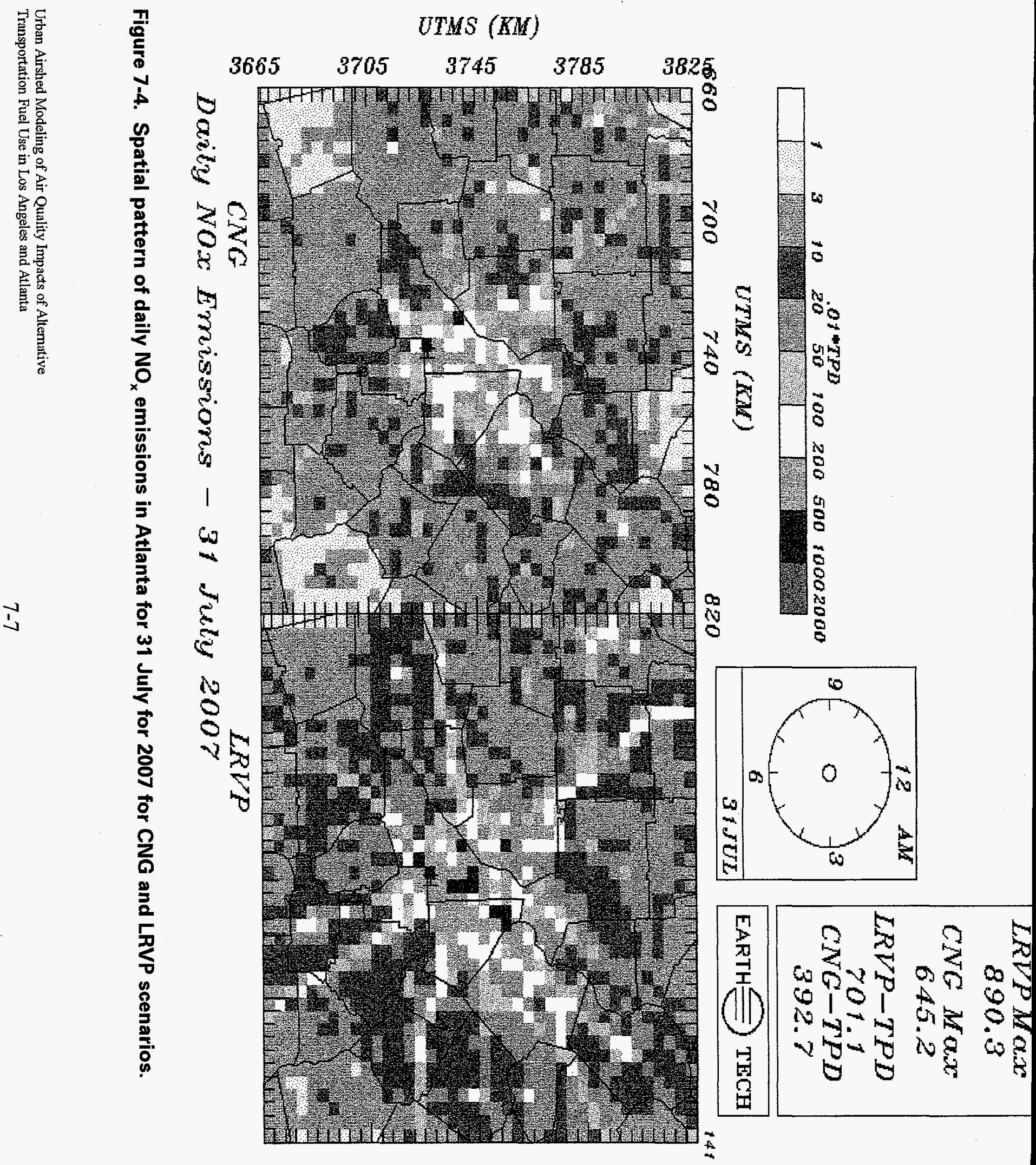




\subsection{Intercomparisons of Daily Maximum Hourly $\mathrm{O}_{3}$}

The changes in the spatial pattern of peak predicted 1-hour average $\mathrm{O}_{3}$ with emissions from LRVP gasoline fueled vehicles can be seen by comparing the daily $\mathrm{O}_{3}$ maxima for the $\mathrm{S} 1$ and LRVP cases, which are displayed in Figure 7-5 for 30 July and Figure 7-6 for 31 July. On 30 July, the maximum $\mathrm{O}_{3}$ concentration for the LRVP scenario occurs north of downtown Atlanta, while the S1 maximum occurs in the industrial region southeast of Atlanta, near the Fulton County airport. The predicted maximum $\mathrm{O}_{3}$ increases from $156 \mathrm{ppb}$ for $\mathrm{S} 1$ to $172 \mathrm{ppb}$ for the gasoline scenario. Another notable difference is significantly lower predicted $\mathrm{O}_{3}$ concentrations west of downtown for the $\mathrm{S} 1$ simulation.

On 31 July (Figure 7-6), the difference in the predicted maximum $\mathrm{O}_{3}$ is significantly smaller, with the $\mathrm{S} 1$ peak value $(172 \mathrm{ppb})$ slightly higher than the LRVP scenario $(168 \mathrm{ppb})$. The pattern of peak predicted $\mathrm{O}_{3}$ for the LRVP scenario cortains an $\mathrm{O}_{3}$ "hole" when compared to the $\mathrm{S} 1$ scenario. The predicted peak moves from southeast of dowitown (Decatur-Stone Mountain area) for S1 to north of downtown (towards Swanee). The LRVP scenario shows lower $\mathrm{O}_{3}$ in the Atlanta urban core, ringed by areas of predicted higher $\mathrm{O}_{3}$. The $\mathrm{O}_{3}$ increases more than $20 \mathrm{ppb}$ over a wide area north of Atlanta in Cherokee County.

The predicted spatial patterns of daily peak 1-hour average surface $\mathrm{O}_{3}$ with and without CNG fuel vehicles are given in Figures 7-7 and 7-8 for 30 and 31 July, respectively. Comparison of the two plots in Figures 7-7 indicates little discernible difference in peak $\mathrm{O}_{3}$ for the $\mathrm{S} 1$ and CNG scenarios for 30 July. On 31 July (Figure 7-8), the location of piak daily $\mathrm{O}_{3}$ coincides for both scenarios. The peak $\mathrm{O}_{3}$ for the $\mathrm{CNG}$ scenario is lower than that for either this S1 or LRVP scenario on 31 July. There is again evidence of an $\mathrm{O}_{3}$ "hole," relative to the $\mathrm{S} 1$ scenario. The major emissions difference between the $\mathrm{S} 1$ and $\mathrm{CNG}$ scenarios is higher $\mathrm{NO}_{\mathrm{x}}$ emissions. We suspect that the lower predicted $\mathrm{O}_{3}$ is caused by titration of $\mathrm{O}_{3}$ with $\mathrm{NO}$ from vehicle emissions.

The maximum and domain average $\mathrm{O}_{3}$ concentrations for each scenario are summarized in Table 7-3. The gasoline vehicle emissions contribute $16 \mathrm{ppb}$ to the maximum peak $\mathrm{O}_{3}$ concentration on 30 July, while peak $\mathrm{O}_{3}$ decreases by $3 \mathrm{ppb}$ (relative to $\mathrm{S} 1$ ) on 31 July. In contrast, CNG fuel vehicles contribute less than 3 $\mathrm{ppb}$ to the maximum concentration on $30 \mathrm{July}$. On 31 July, the CNG scenario produces a $6 \mathrm{ppb}$ decrease in peak $\mathrm{O}_{3}$.

Table 7-3. Daly Maximum and Domain Average Peak $\mathrm{O}_{3}$ Concentrations for 2007 Atlanta Emission Scenarios (units are ppb)

\begin{tabular}{lccc}
\hline Statistic & Scenario & 30 July & 31 July \\
\hline Maximum daily 1-hr & S1 & 156 & 172 \\
Maximum daily 1-hr & LRVP & 172 & 168 \\
Maximum daily 1-hr & CNG & 159 & 166 \\
Domain average 1-hr & S1 & 53.4 & 55.3 \\
Domain average 1-hr & LRVP & 56.8 & 57.9 \\
Domain average 1-hr & CNG & 54.1 & 55.9 \\
\hline
\end{tabular}




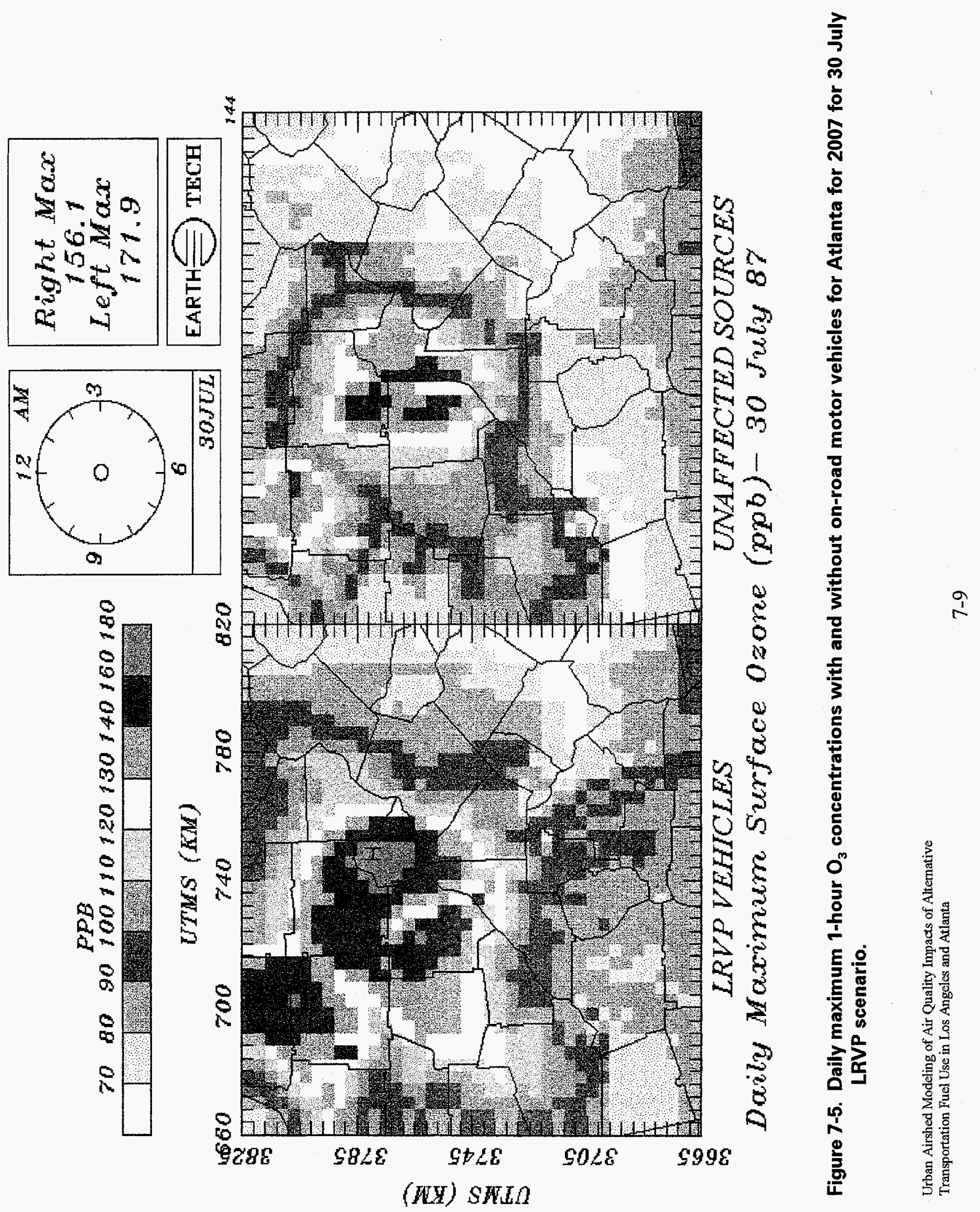




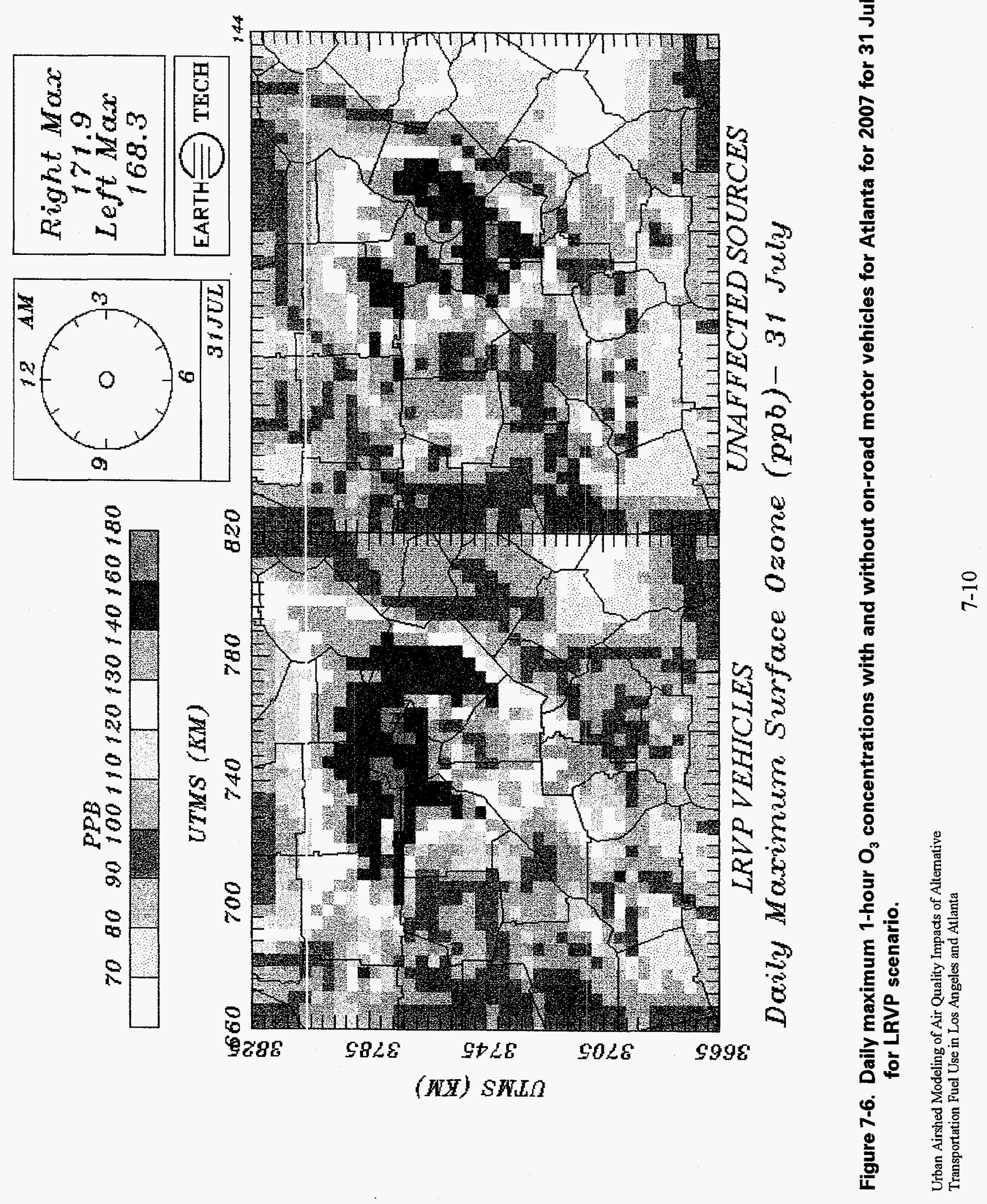




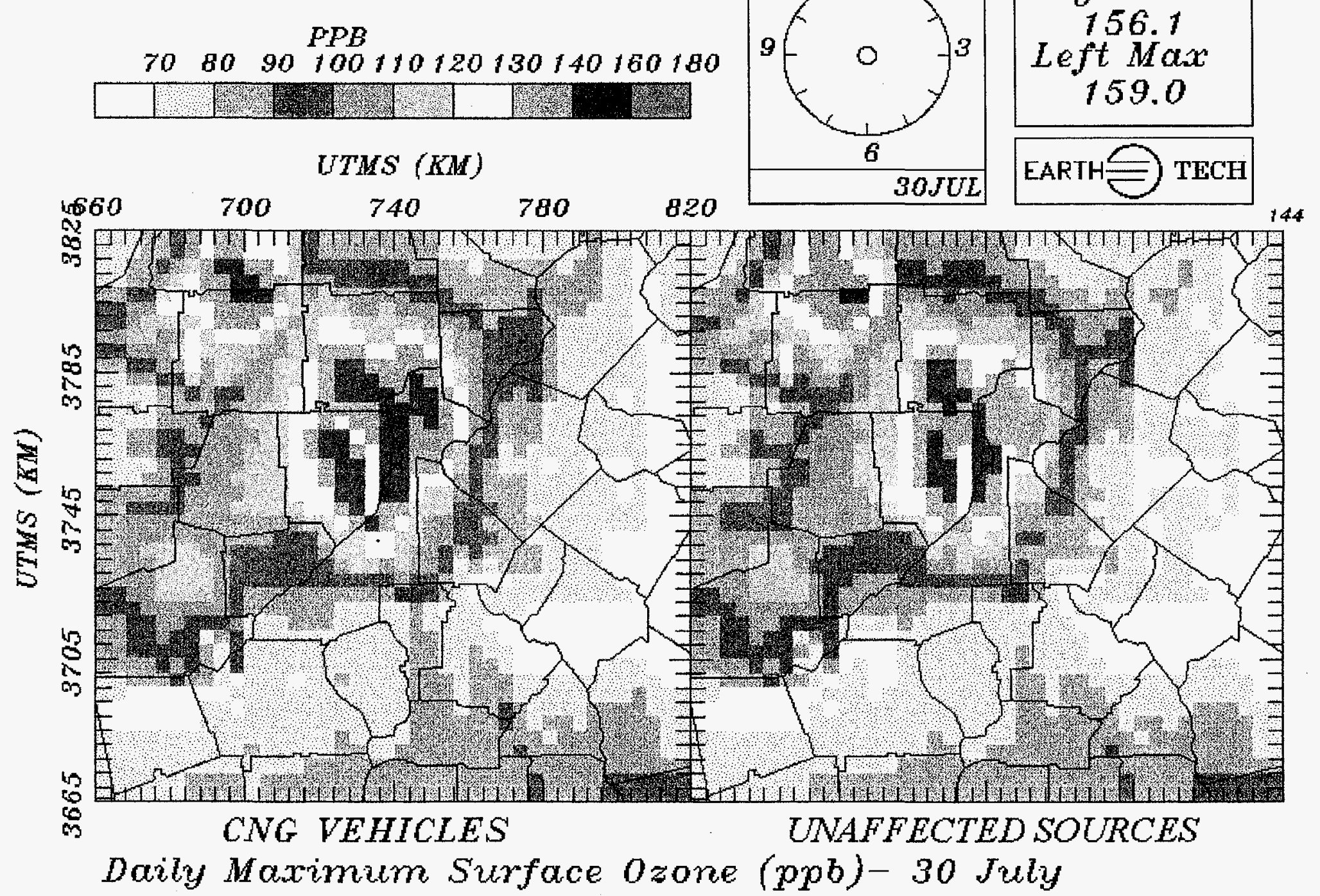

Figure 7-7. Daily maximum 1-hour $\mathrm{O}_{3}$ concentrations with and without on-road motor vehicles for Atlanta for 2007 for 30 July for CNG scenario. 


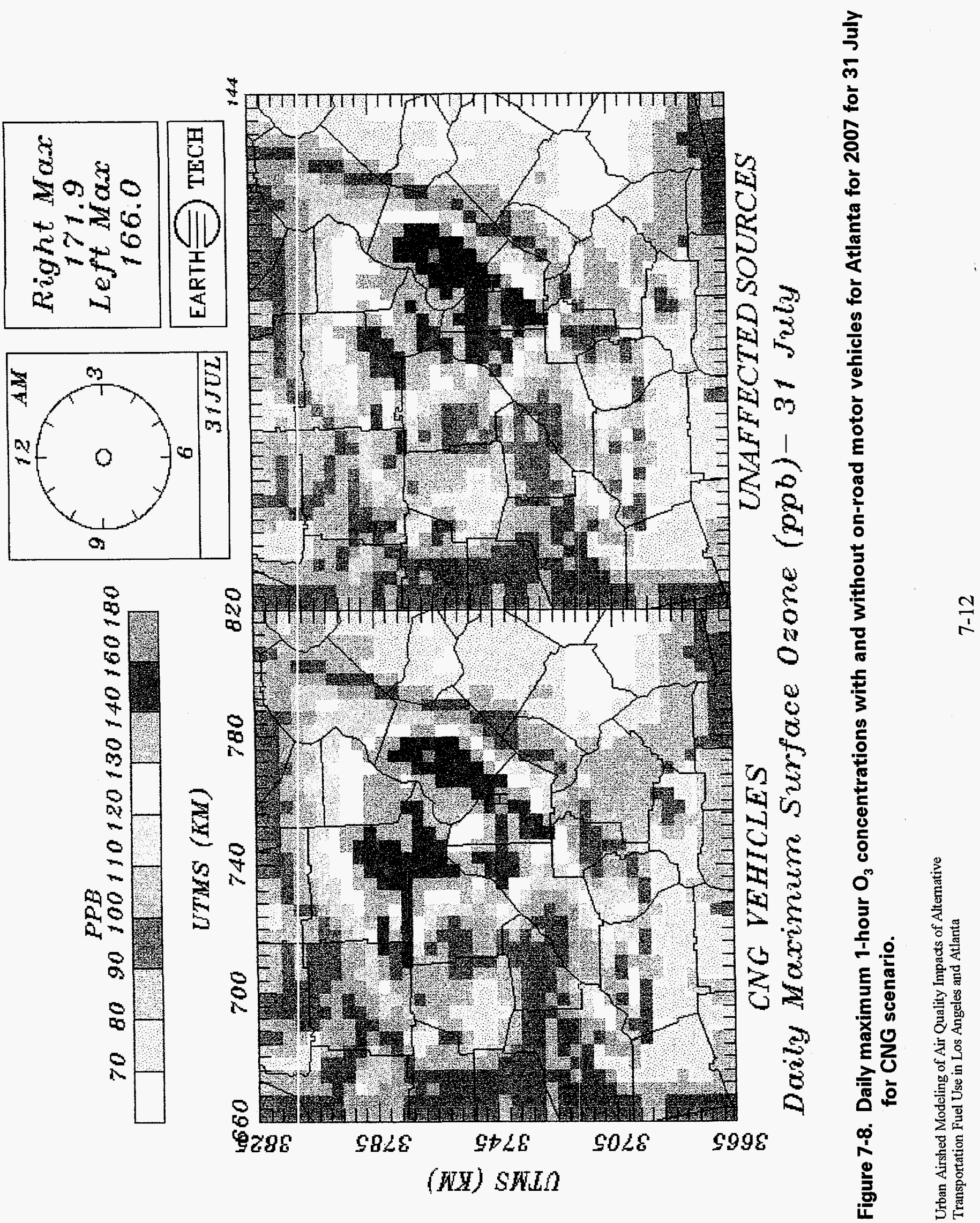


Predicted daily maximum 1-hour VOC concentrations for the LRVP and CNG scenarios are shown in Figure 7-9 for 31 July. The peak VOC concentrations occur in the vicinity of the Dekalb County airport. The maximum VOC concentration for the LRVP scenario is about $50 \%$ higher than the CNG scenario, reflecting the large difference in VOC emissions.

The daily peak 1-hour $\mathrm{NO}_{\mathrm{x}}$ concentrations for LRVP and CNG scenarios are shown in Figure 7-10 for 31 July. The maximum predicted $\mathrm{NO}_{\mathrm{x}}$ concentration for the LRVP scenario is $80 \%$ higher than the CNG maximum, which again illustrates the large differences in emissions. In terms of the spatial patterns of $\mathrm{NO}_{\mathrm{x}}$ concentrations, the largest differences show up in the major highway corridors and in the urban core of Atlanta.

\subsection{Intercomparisons of Daily Maximum 8-Hour Ozone}

The maximum daily and domain-average 8-hour $\mathrm{O}_{3}$ concentrations for the CNG and LRVP scenarios for both days are given in Table 7-4. The spatial pattern of daily peak 8-hour average $\mathrm{O}_{3}$ concentrations for the CNG and LRVP scenarios are shown in Figures 7-11 and 7-12 for 30 and 31 July, respectively. For both fuel scenarios, the patterns of 8-hour average $\mathrm{O}_{3}$ concentrations on 31 July are similar to the peak 1hour concentrations shown in Figures 7-6 and 7-8, including the $\mathrm{O}_{3}$ "holes". The predicted 8-hour maximum concentrations for both scenarios increase, relative to $S 1$, unlike the predicted decreases seen for peak 1-hour concentrations. On 30 July, the maximum 8 -hour $\mathrm{O}_{3}$ concentration increases by $18 \mathrm{ppb}$, relative to $\mathrm{S} 1$. The domain-wide maximum 8 -hour average $\mathrm{O}_{3}$ concentrations decrease for both scenarios from 30 July to 31 July. For both days, the LRVP scenario results in higher 8-hour $\mathrm{O}_{3}$ concentrations than does the CNG scenario.

\section{Table 7-4. Maximum and Domain-Average Peak 8-hr Average $\mathrm{O}_{3}$ Concentration in the Atlanta Modeling Domain (units are ppb)}

\begin{tabular}{lccc}
\hline \multicolumn{1}{c}{ Statistic } & Scenario & 30 July & 31 July \\
\hline Maximum daily 8-hr & S1 & 126.0 & 118.1 \\
Maximum daily 8-hr & LRVP & 143.6 & 121.7 \\
Maximum daily 8-hr & CNG & 128.7 & 119.7 \\
Domain average 8-hr & S1 & 53.4 & 55.3 \\
Domain average 8-hr & LRVP & 56.7 & 57.9 \\
Domain average 8-hr & CNG & 54.1 & 55.9 \\
\hline
\end{tabular}

The maximum predicted 8-hour $\mathrm{O}_{3}$ concentration remains in the same location for $\mathrm{S} 1$ and for both fuel scenarios, in Gordon County at the northwestern edge of the modeling domain. The concentration pattern for the CNG scenario is very similar to the $\mathrm{S} 1$ case. 


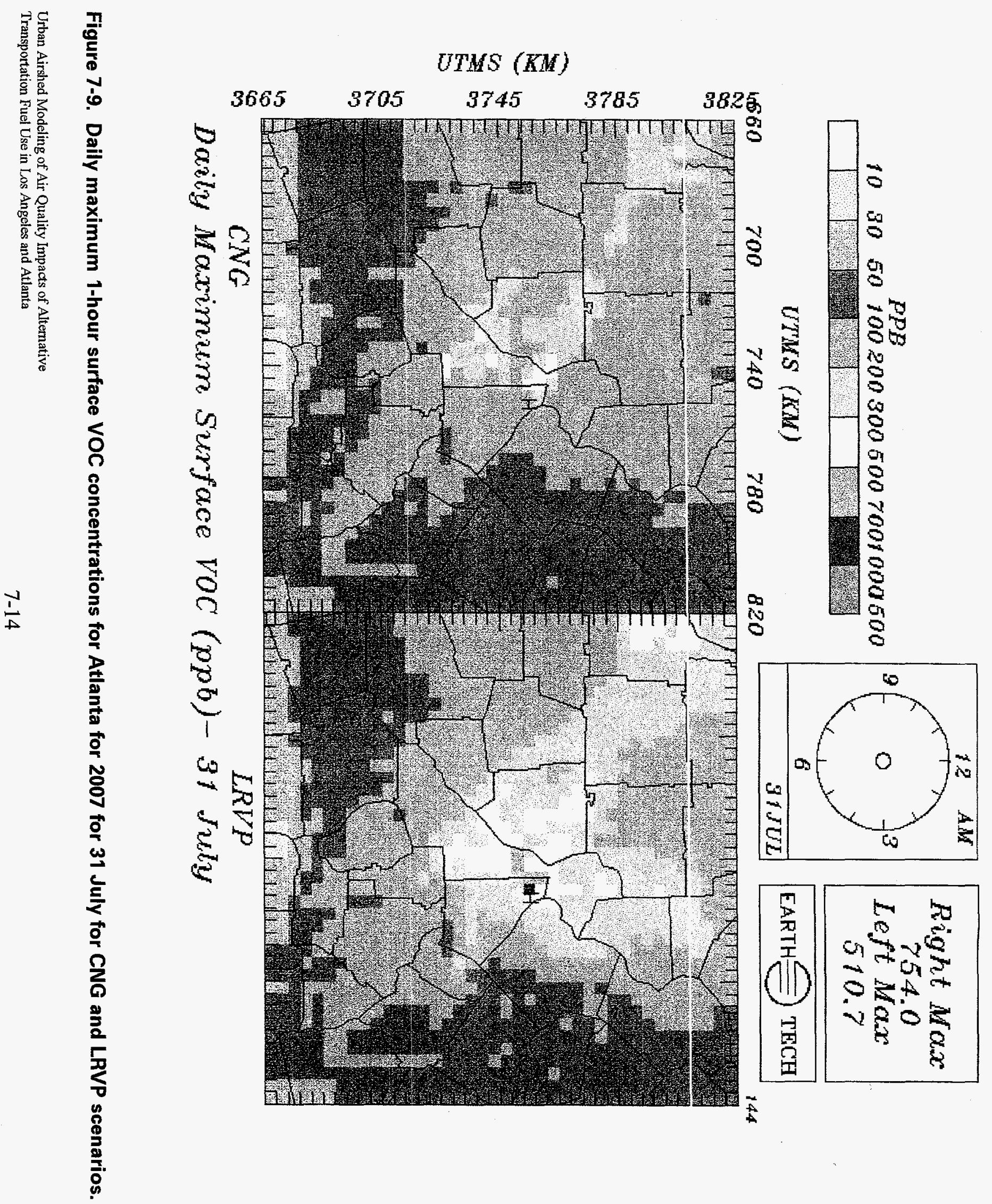




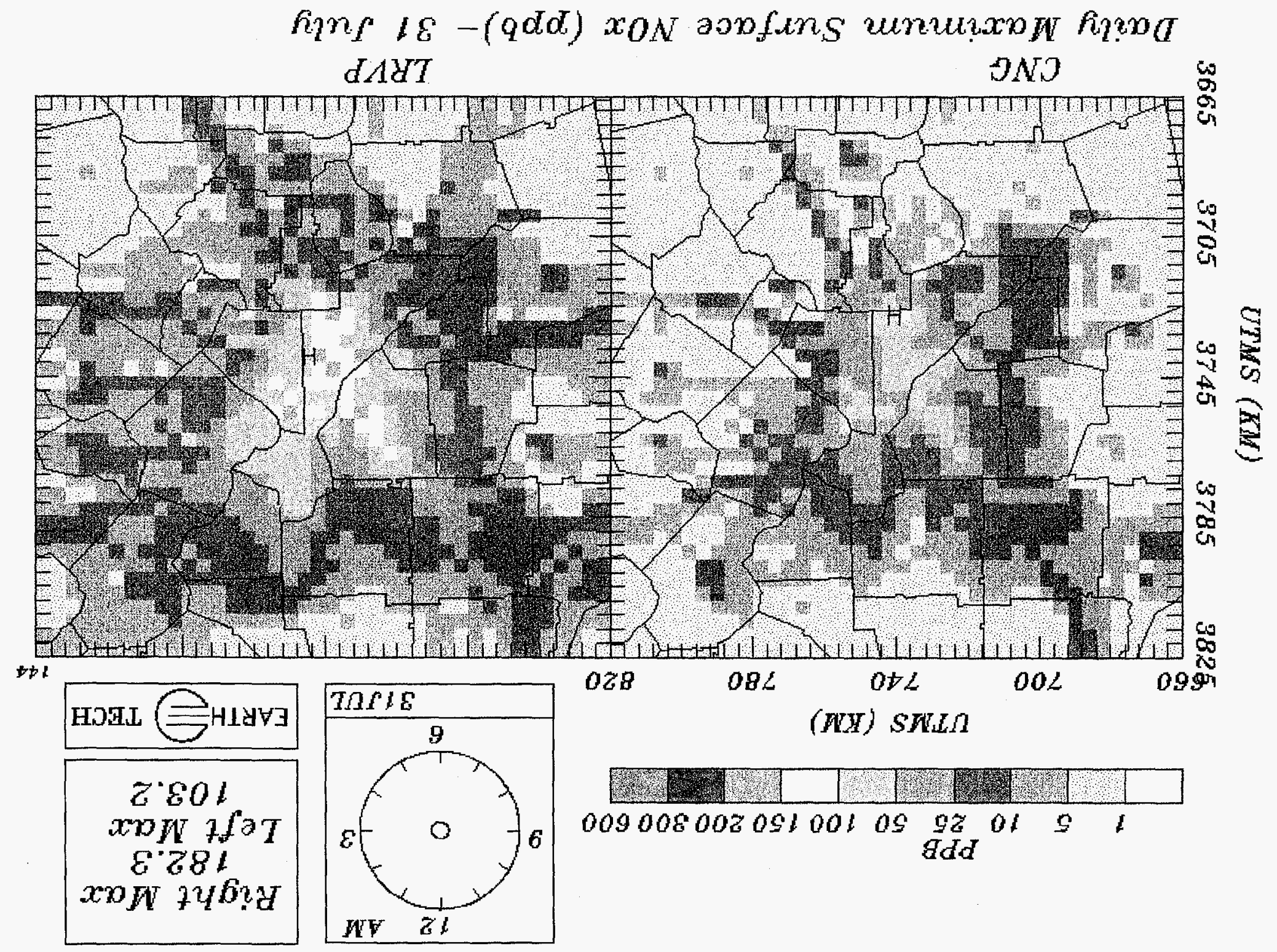




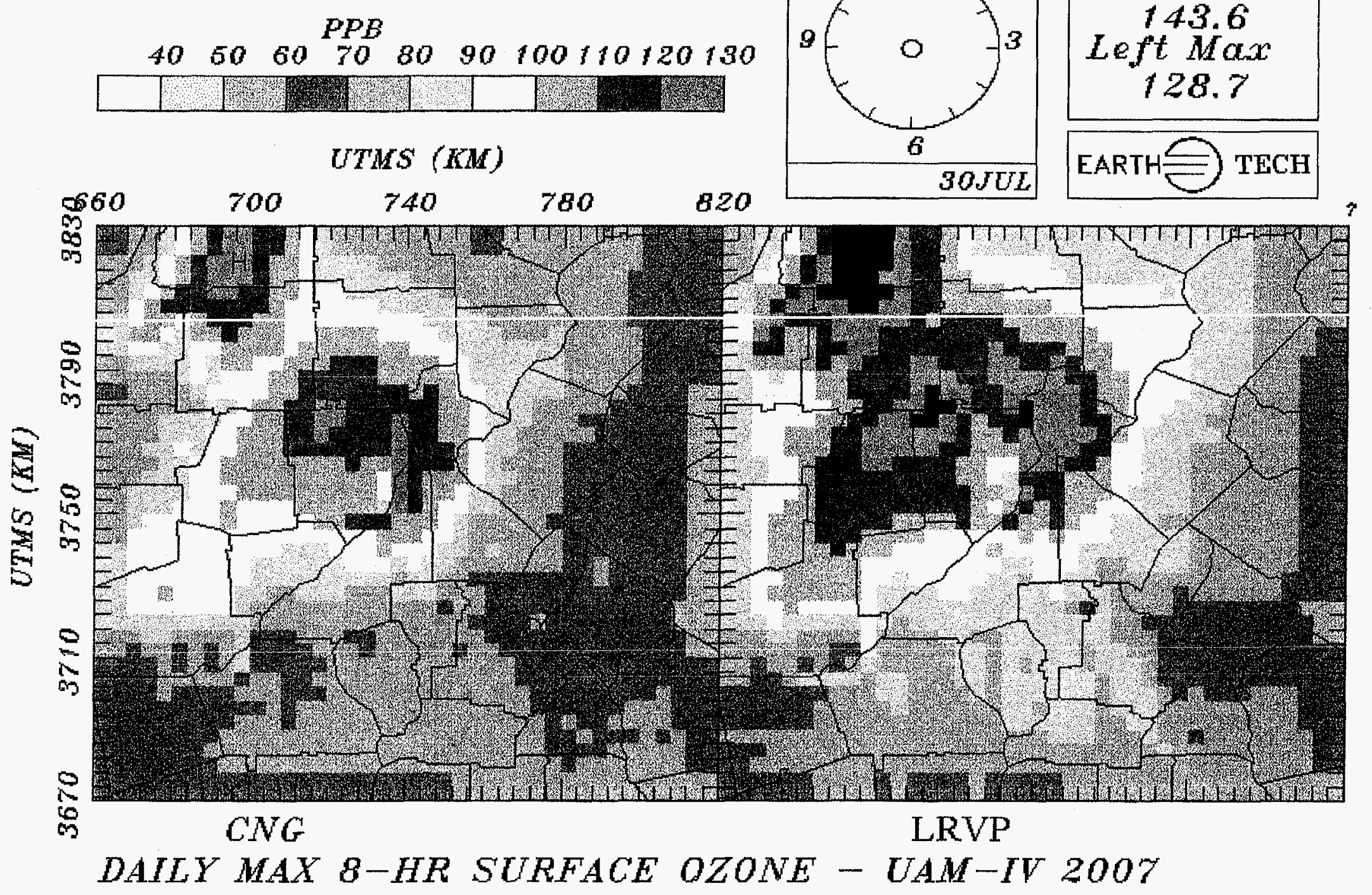

Figure 7-11. Daily maximum 8-hour surface $\mathrm{O}_{3}$ concentrations for Atlanta for 2007 for 30 July for CNG and LRVP scenarios. 


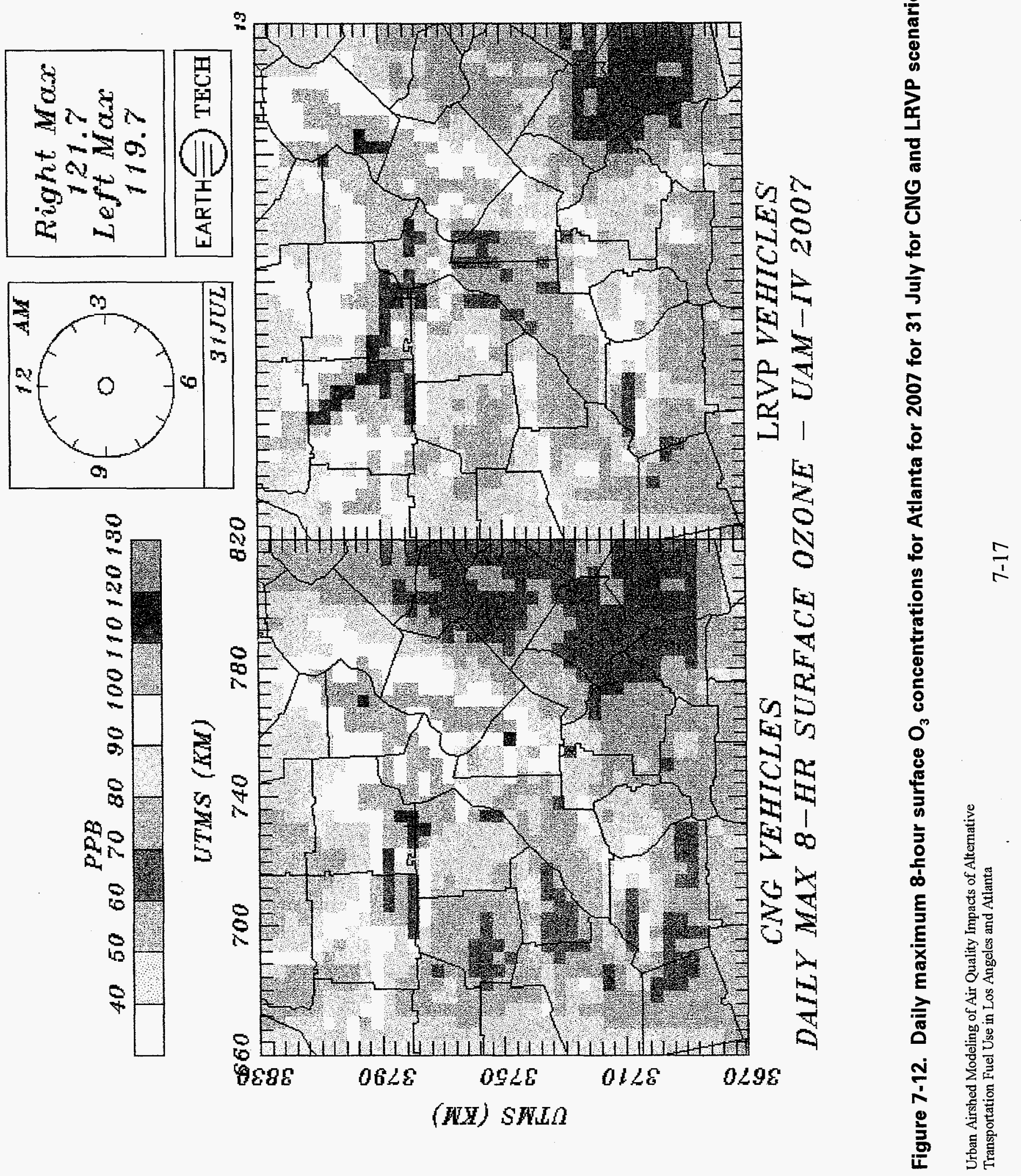




\subsection{Intercomparisons of Exposures to Ozone and Toxics}

Population exposure estimates were developed using a population file supplied by DNR, representing 1990 census data distributed to a $4 \times 4 \mathrm{~km}$ grid. The population density for the Atlanta modeling domain is displayed in Figure 7-13. The maximum population density is located in downtown Atlanta as would be expected. The peak population density is approximately 2,200 people per square kilometer $(35,000$ per grid cell).

The exposure to $\mathrm{O}_{3}$ was estimated on a daily basis as the sum over all hours of the product of the hourly predicted $\mathrm{O}_{3}$ concentration ir. a cell times the population present in the grid cell. Two sets of exposure estimates were calculated, the first (No Threshold) using all hourly concentrations, and the second (Threshold $80 \mathrm{ppb}$ ) using only hourly concentration predictions exceeding $80 \mathrm{ppb}$. The domain-wide daily exposures to $\mathrm{O}_{3}$ are summarized in Table 7-5. No Threshold exposures for the three scenarios for the two days are within $5 \%$ of each other. On 30 July, the LRVP scenario has the highest exposure, while on 31 July, higher exposures are calculated for the CNG and S1 scenarios. With an 80 ppb concentration threshold, exposure estimates are lower by roughly a factor of 10 . The differences between scenarios are more pronounced, with the highest exposure estimates on both days for the LRVP scenario, roughly $25 \%$ higher than the S1 scenario. For each scenario, the exposure estimates for 30 July and 31 July are very similar. The $80 \mathrm{ppb}$ thresholc exposures for Atlanta are considerably higher than those calculated for Los Angeles, despite the lower pcpulation, which reflects predicted peak ozone concentrations above $80 \mathrm{ppb}$ that cover a larger area and fersist for more hours.

The spatial distribution and magnitude of No Threshold $\mathrm{O}_{3}$ exposures are very similar between the CNG and gasoline scenarios for both modeling days. Plots of cumulative $\mathrm{O}_{3}$ exposure for the CNG and LRVP scenarios are given for $31 \mathrm{Jul} / \mathrm{in}$ Figure 7-14, the day with the highest modeled $\mathrm{O}_{3}$ exposures. Note that the units are ppm-people-hours. The peak in $\mathrm{O}_{3}$ exposure occurs in the vicinity of downtown Atlanta, in the grid cell with the highest fopulation density. The largest differences in $\mathrm{O}_{3}$ exposures, while not shown in the figure, occur in central Atlanta (Fulton County proper), an area of high surface $\mathrm{NO}_{\mathrm{x}}$ emissions.

Table 7.5. Estimated Population Exposures to Predicted $\mathrm{O}_{3}$ Concentrations in Atlanta for 2007 (units are $10^{6}$ people $x$ ppm-hours)

\begin{tabular}{ccc|cc}
\hline & \multicolumn{2}{c|}{ No Threshold } & \multicolumn{2}{c}{$80 \mathrm{ppb}$ Threshold } \\
Emission Scenario & 30 July & 31 July & 30 July & 31 July \\
\hline S1 & 4.4 & 4.6 & 0.47 & 0.46 \\
LRVP & 4.5 & 4.4 & 0.59 & 0.59 \\
CNG & 4.4 & 4.6 & 0.49 & 0.49 \\
\hline
\end{tabular}




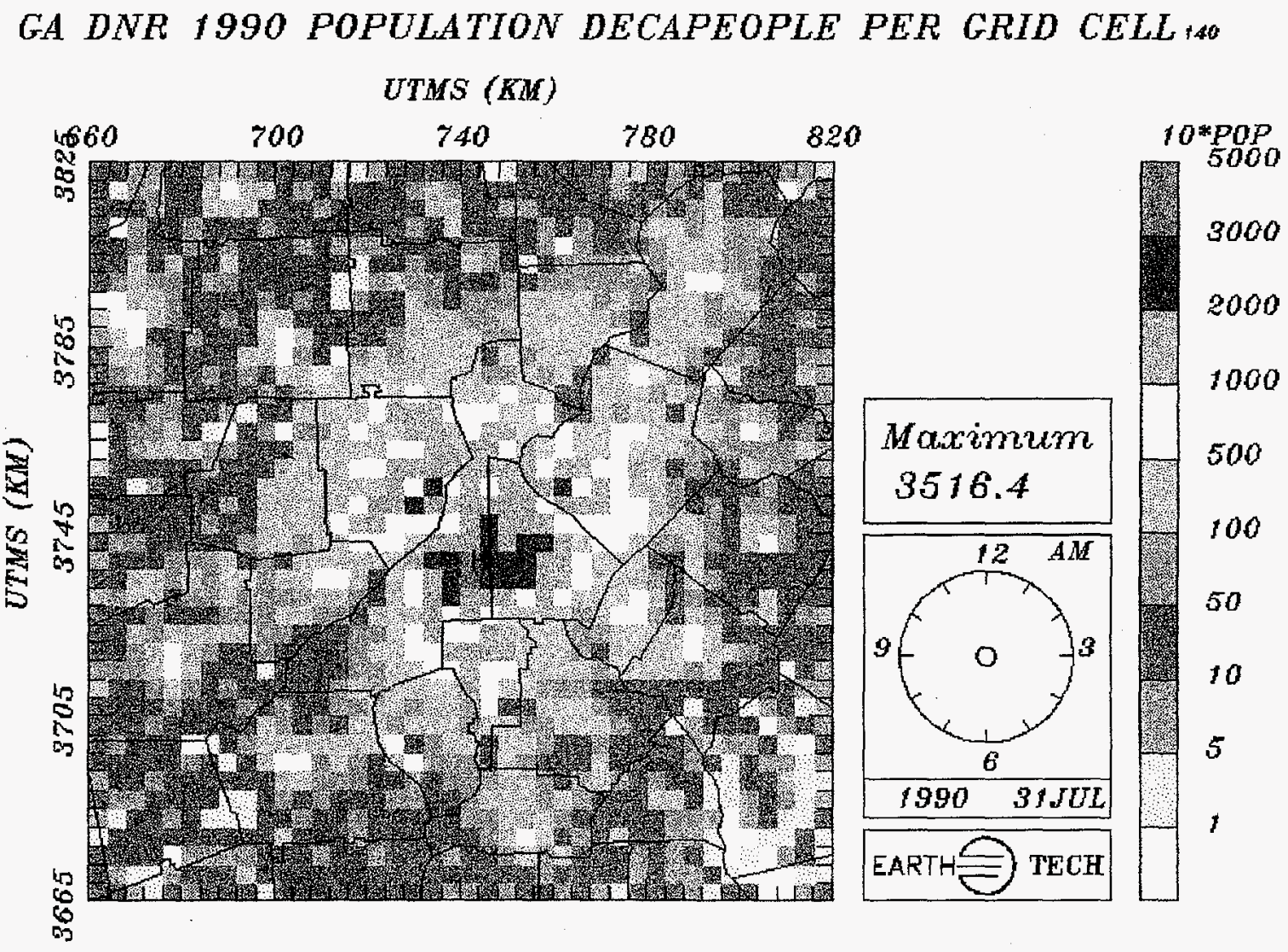

Figure 7-13. Population density in the Atlanta modeling domain for 1990.

Urban Airshed Modeling of Air Quality Impacts of Alternative

Transportation Fuel Use in Los Angeles and Atlanta 


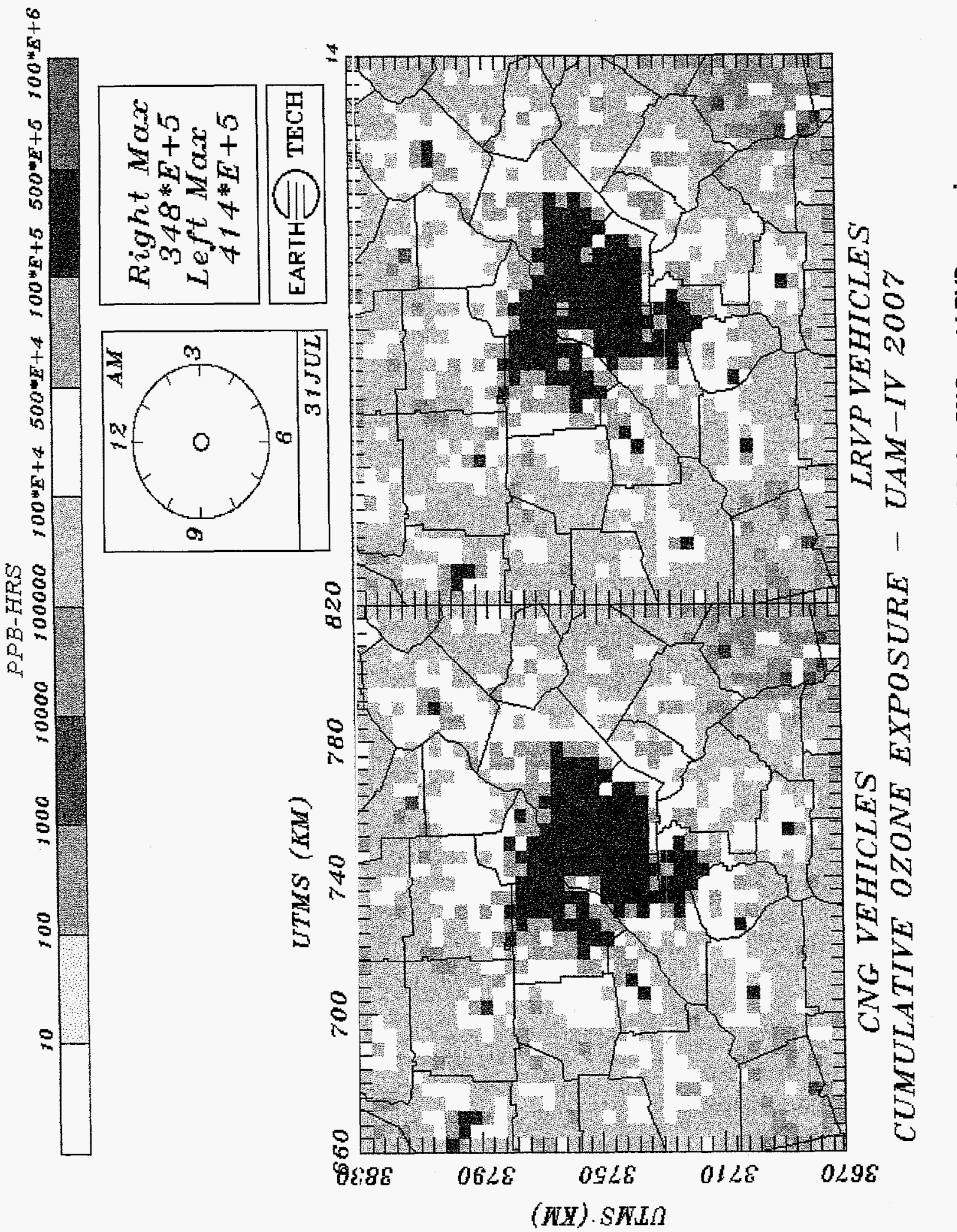

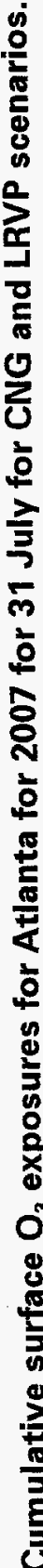

줏

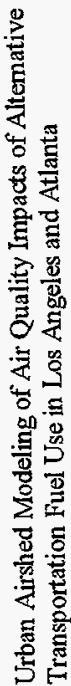


The maximum daily 1-hour concentrations and the population exposure to the four toxic compounds (FORM, ACET, BENZ, and BUDI) are summarized in Table 7-6. Several observations can be made from this table including the following:

- $\quad$ Of all the toxic compounds examined, predicted concentrations and population exposures for FORM are the largest.

- $\quad$ Peak exposures tend to occur on 31 July for all compounds.

- The largest predicted toxic concentrations and exposures occur for the LRVP gasoline scenario.

- The CNG and S1 scenarios are most similar in terms of the maximum predicted concentrations and exposures.

The cumulative FORM exposure patterns for 31 July for the LRVP and CNG scenarios are shown in Figure 7-15. Note that the units are ppb-people-hours. The highest predicted exposure occurs in the vicinity of downtown Atlanta. The LRVP scenario exposures to FORM are most different from those of the CNG scenario in and around Atlanta. The CNG pattern of population exposure to toxic compounds is most like that of the S1 scenario (not shown).

Table 7-6. Daily Maximum 1-Hour Concentrations and Domain-wide Cumulative Populations Exposures to Each of the Four Toxic Compounds in the Atlanta Modeling Domain for $\mathbf{2 0 0 7}$ (units are $\mathrm{ppb}$ people-hours)

\begin{tabular}{lcccccc}
\hline Statistic & Date & Scenario & FORM & ALD2 & BENZ & BUDI \\
\hline Maximum daily 1-hr & \multirow{2}{*}{30 July } & S1 & 14.1 & 6.31 & 1.21 & 2.12 \\
& & LRVP & 15.4 & 6.48 & 2.24 & 2.00 \\
Maximum daily 1-hr & \multirow{2}{*}{31 July } & CNG & 14.2 & 6.32 & 1.24 & 2.08 \\
& & S1 & 18.2 & 6.70 & 1.26 & 2.91 \\
& & LRVP & 18.7 & 7.55 & 3.20 & 3.00 \\
Cumulative exposure & \multirow{3}{*}{30 July } & CNG & 18.2 & 6.75 & 1.05 & 2.91 \\
& & S1 & 0.36 & 0.13 & 0.0190 & 0.0032 \\
& & LRVP & 1.39 & 0.14 & 0.034 & 0.0040 \\
Cumulative exposure & \multirow{2}{*}{31 July } & CNG & 0.36 & 0.13 & 0.019 & 0.0032 \\
& & S1 & 0.33 & 0.13 & 0.0194 & 0.0035 \\
& & LRVP & 0.36 & 0.14 & 0.036 & 0.0049 \\
& & CNG & 0.33 & 0.13 & 0.0196 & 0.0035 \\
\hline
\end{tabular}




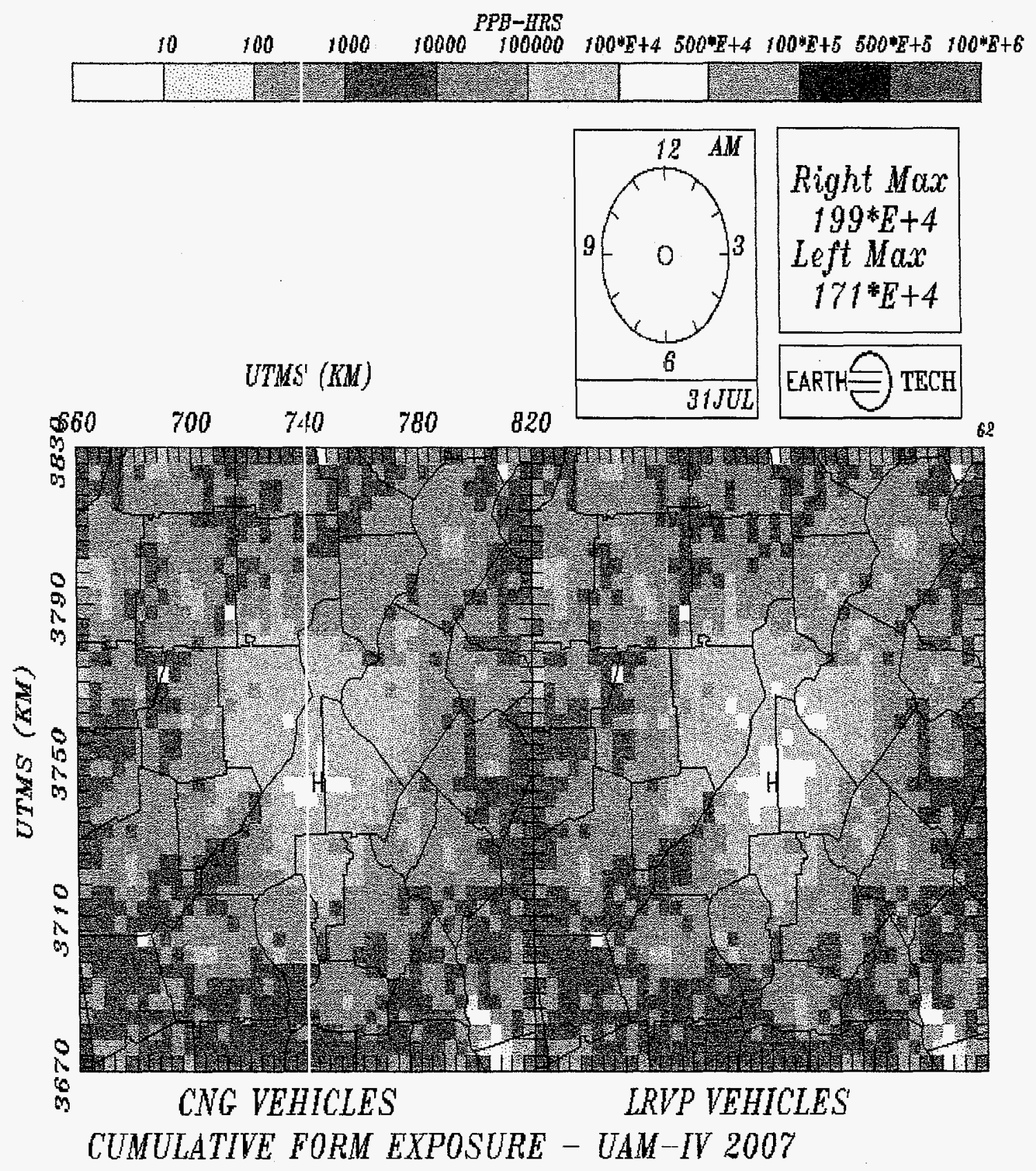

Figure 7-15. Cumulative sIJrface FORM exposures for Atlanta for 2007 for 31 July for CNG and LRVP scenarios.

\subsection{Relative Ozone Formation Potential Analysis}

In order to place the VOC emissions for the CNG and LRVP scenarios on an equal footing, the VOC totals can be weighted by their ability to form $\mathrm{O}_{3}$, expressed as the total amount (moles) of $\mathrm{O}_{3}$ formed or destroyed per ton of each VOC species emilted. In Atlanta, the urban core is surrounded by rural areas where biogenic emissions are quite large, resulting is a large spatial variation in VOC:NO ${ }_{x}$ ratio. The spatial variation is demonstrated dramatically by Figure 7-13 which shows the daily average VOC: $\mathrm{NO}_{\mathrm{x}}$ concentration ratios 
In order to place the VOC emissions for the CNG and LRVP scenarios on an equal footing, the VOC totals can be weighted by their ability to form $\mathrm{O}_{3}$, expressed as the total amount (moles) of $\mathrm{O}_{3}$ formed or destroyed per ton of each VOC species emitted. In Atlanta, the urban core is surrounded by rural areas where biogenic emissions are quite large, resulting is a large spatial variation in VOC: $\mathrm{NO}_{\mathrm{x}}$ ratio. The spatial variation is demonstrated dramatically by Figure 7-13 which shows the daily average VOC:NO ${ }_{x}$ concentration ratios predicted by the UAM-IV for the CNG and LRVP scenarios. The gasoline scenario shows a dramatic change in the VOC:NO ratio compared with the CNG case, with highway corridors showing up with significantly reduced ratios (e.g., 5-10 is common). The result suggests that (1) air moving from the urban core to the outskirts of Atlanta will experience large changes in VOC:NO ratios (over an order of magnitude), and (2) gasoline-fueled vehicle emissions lead to a situation where the urban core is definitely not in a $\mathrm{NO}_{\mathbf{x}}$ limited state.

For this study, one would like to be able to calculate the ozone formation potential (ozone formed per unit emission) that would result from use of a given alternative fuel. Multiple model runs in which small emissions increments are applied independently to each CB-4 species that is emitted by use of a given fuel are made, and the resulting formation potentials are summed to yield the composite ozone formation potential of the fuel. However, there is a conflict between using a small enough emissions increment to maintain linearity in the resulting chemical calculations and using a large enough increment to produce a statistically detectable change in ozone concentration.

For this study, a method of establishing a statistically significant yet linearity-preserving emission increment for each specie was not available. The scope of the study did not allow development of either direct differentiation versions (e.g., ADIFOR - Bischof, 1994) or direct decoupled method versions (e.g., Yang et al., 1997) of UAM-IV to yield incremental emissions sensitivities. Also, this study involves a specific episode with specific space- and time-varying meteorological conditions and overall emissions, so using generic specie ozone forming potentials from the literature and applying them on a weighted basis to the present emissions mix for LRVP and CNG would introduce uncertainties.

This study used a compromise approach to examine ozone forming potentials of the alternative fuels. A single generic set of incremental runs by specie was done. The increments chosen represented the difference between the LRVP emissions case and the no-motor-vehicles case, except for several species for which a larger increment was necessary to produce a significant response, and the results were assumed to represent the average ozone formation potential for these individual species over the range of motor vehicle emissions spanning no vehicles to the full LRVP case. The emissions from the CNG case will fall within this range, and these average species-specific ozone potentials can be weighted to produce a fuel-specific ozone formation potential for either RFG or CNG. Any proposed approach would be limited by the factors discussed above; this approach has the advantage that the specie-specific ozone formation potentials are appropriate for this set of episode conditions, domain, and emissions mix.

A series of nine simulations was conducted in which an emissions increment for a single CB4 chemical species was added to the $\mathrm{S} 1$ emissions. Table 7-7 lists these incremental species emissions $(\Delta Q s$.) The emission increments for most species correspond to the LRVP gasoline scenario motor vehicle emissions. For selected species (FORM, ACET, and ISOP), emissions were scaled by factors of 10 or 300 in order to produce a numerically significant $\mathrm{O}_{3}$ response. The estimated peak $\mathrm{O}_{3}$ sensitivity and the $\mathrm{O}_{3}$ formation potential for each pollutant is therefore dependent on the degree to which the $\mathrm{O}_{3}$ response can be linearly scaled. 
The $\mathrm{O}_{3}$ sensitivity with the largest absolute magnitude is that for $\mathrm{NO}_{\mathrm{x}}$. The negative sign indicates that $\mathrm{NO}_{\mathrm{x}}$ in Atlanta, on average, is more effective in destroying $\mathrm{O}_{3}$ through titration than in promoting ozone formation. OLE and FORM are the two compounds most efficient at forming $\mathrm{O}_{3}$ on a per ton basis, while PAR and TOL, which account for the largest fractions of VOC emissions, contribute the least to ozone production on a per ton basis.

Table 7-7. $\mathrm{O}_{3}$ Sensitivities (ppb/ton) Based on Maximum 1-Hour Average $\mathrm{O}_{3}$ Concentrations in Atlanta on 31 July (unless noted otherwise, the $\Delta Q$ is the difference between $\mathbf{S 1}$ and LRVP emissions scenarios)

\begin{tabular}{cccc}
\hline Species & $\Delta O 3(\mathrm{ppb})$ & $\Delta \mathrm{Q}(\mathrm{TPD})$ & $\Delta \mathrm{O})$ \\
\hline NOX & -14.4 & 363 & -0.040 \\
PAR & 5.40 & 132 & 0.041 \\
TOL & 0.65 & 34.0 & 0.019 \\
XYL & 3.06 & 29.0 & 0.106 \\
FORM & 6.31 & $14.7^{*}$ & 0.429 \\
ACET & 2.31 & $9.0^{* *}$ & 0.257 \\
OLE & 4.89 & 11.6 & 0.422 \\
ETH & 3.09 & 11.0 & 0.281 \\
ISOP & 2.34 & $19.0^{* *}$ & 0.123 \\
\hline
\end{tabular}

* $=10 \times$ actual

** $=300 \times$ actual

These $\mathrm{O}_{3}$ sensitivities are typical and are similar to those reported by Bergin et al (1995). The peak $\mathrm{O}_{3}$ at the surface is formed through the competing processes of $\mathrm{O}_{3}$ destruction through $\mathrm{NO}_{\mathrm{x}}$ titration and radical scavenging and $\mathrm{O}_{3}$ production $\mathrm{r} \in$ sulting from $\mathrm{NO}_{2}$ formation by radical chemistry. Bergin et al found that $\mathrm{O}_{3}$ sensitivity for TOL is a function of the prevailing VOC:NO $\mathrm{NO}_{\mathrm{x}}$ emissions ratio, with negative sensitivity for VOC: $\mathrm{NO}_{x}$ ratios above 14 . Our calculations for 31 July show a small positive $\mathrm{O}_{3}$ sensitivity for TOL. Figure 7-16 demonstrates that the average VOC: $\mathrm{NO}_{\mathrm{x}}$ ratio over Atlanta is of order 5-10, a range where Bergin et al indicate that positive $\mathrm{O}_{3}$ sensitivity for $\mathrm{TOL}$ is expected. (As noted earlier, however, large spatial variations in VOC: $\mathrm{NO}_{\mathrm{x}}$ yatio occur across the domain.)

Peak $\mathrm{O}_{3}$ sensitivity is not always a good indicator of $\mathrm{O}_{3}$ formation potential, since the meteorological component of the $\mathrm{O}_{3}$ buildup cannot easily be separated from the emissions. For example, the domain maximum prediction will not respond equally to emissions that occur in different parts of the domain. An approach that is less dependent on source characteristics and dispersion patterns is to estimate how many tons of $\mathrm{O}_{3}$ were formed or destrcyed per ton of a specific chemical emitted, across the entire domain, using the same series of simulations desscribed above. Domain-wide net $\mathrm{O}_{3}$ production was therefore estimated for 31 July. The resulting $\mathrm{O}_{3}$ formation potentials, stated as tons of $\mathrm{O}_{3}$ per ton of emissions, are summarized in Table 7-8. 
Table 7-8. $\mathrm{O}_{3}$ Formation Potentials (ton- $\mathrm{O}_{3} /$ ton-Q) Over Atlanta Modeling Domain for 31 July Episode Day

\begin{tabular}{ccccc}
\hline Species & $\Delta M^{\mathrm{a}}$ tons & $\Delta \mathrm{Q}$ (TPD) & $\Delta \mathrm{M} / \Delta \mathrm{Q}$ ton/ton & Reactivity weight \\
\hline NOX & 383 & 363 & 1.05 & $\mathrm{NA}$ \\
PAR & 4.0 & 132 & 0.030 & 0.021 \\
TOL & -32.0 & 34.0 & -0.941 & -0.669 \\
XYL & -5.0 & 29.0 & -0.172 & -0.122 \\
FORM & 15.0 & 14.7 & 1.020 & 0.725 \\
ACET & 0.0 & 9.0 & 0.0 & 0.0 \\
OLE & 16.0 & 11.6 & 1.38 & 0.980 \\
ETH & 1.0 & 11.0 & 0.091 & 0.065 \\
ISOP & 0.0 & 18.0 & 0.0 & 0.0 \\
\hline
\end{tabular}

${ }^{a}$ Cumulative Mass change for hour beginning 2300 on 30 July thru 2400 on 31 July.

Table 7-8 also presents VOC reactivity weights that are calculated by dividing the individual sensitivities by the sum of all the VOC sensitivities. Any fuel can be weighted on the basis of reactivity using the weights presented in Table 7-8. From these results, we see that the ozone formation potentials for TOL and XYL are negative, in contrast to the ozone sensitivities in Table 7-7. 


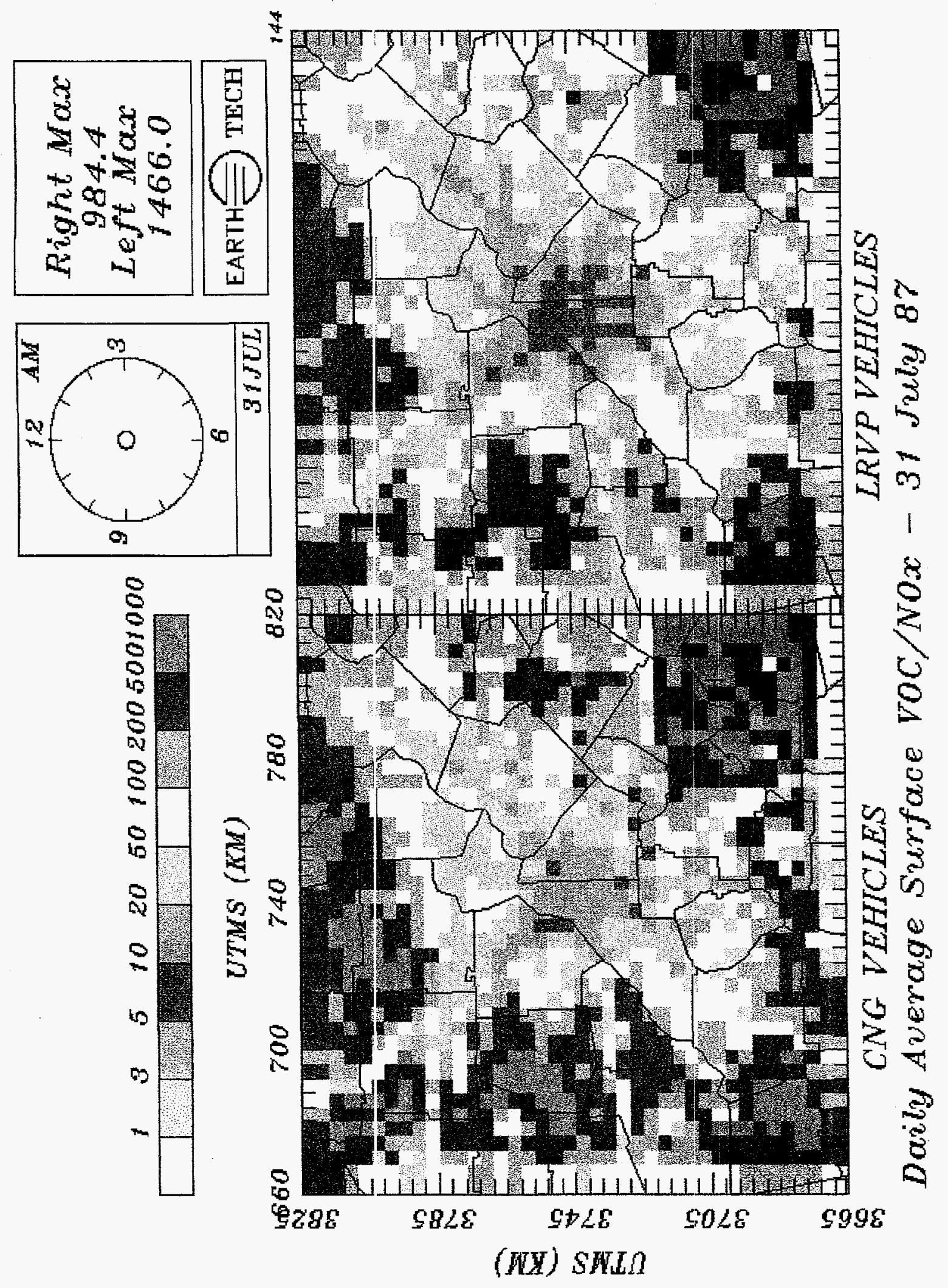

올

$\sum_{10}^{0}$

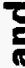

$\sum_{0}^{0}$

온

$\frac{2}{3}$

5

के

옹

옹

焉

\%

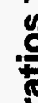

$\stackrel{2}{i}$

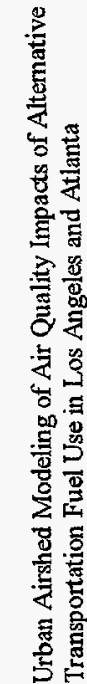


Table 7-9. A Summary of Actual and Reactivity-Weighted Daily VOC Emissions from Alternatively Fueled vehicles by Species for 31 July 2007 in the Atlanta Modeling Domain (units are tons/day)

\begin{tabular}{lcccc}
\hline & \multicolumn{2}{c}{ LRVP Fuel Vehicles } & \multicolumn{2}{c}{ CNG Fuel Vehicles } \\
\hline Species & Emissions & $\begin{array}{c}\text { Reactivity } \\
\text { Weighted } \\
\text { Emissions }\end{array}$ & Emissions & $\begin{array}{c}\text { Reactivity } \\
\text { Weighted } \\
\text { Emissions }\end{array}$ \\
PAR & 130 & 2.73 & 2.82 & 0.06 \\
OLE & 12 & 11.76 & 0.99 & 0.48 \\
ETH & 11 & 0.72 & 0.39 & 0.03 \\
TOL & 34 & -22.75 & 0.27 & -0.18 \\
XYL & 29 & -3.54 & 0.25 & -0.03 \\
FORM & 1.5 & 1.09 & 0.07 & 0.05 \\
ACET & 0.90 & 0.0 & 0.04 & 0.0 \\
ISOP & 0.0 & 0.0 & 0.0 & 0.0 \\
Total & 218.4 & -10.0 & 4.33 & 0.41 \\
\hline
\end{tabular}

* Remainder of emissions do not change and were not modeled with a sensitivity simulation.

It is uncertain how an $\mathrm{X} \%$ increase in VOC emissions from CNG-fueled vehicles will increase $\mathrm{O}_{3}$ formation relative to an $\mathrm{X} \%$ increase in VOC emissions from gasoline-fueled vehicles. By weighting the emissions by reactivity, we can compare on an equal footing the $\mathrm{O}_{3}$ formation potential of changes in VOC emissions for different fuel scenarios. Such a reactivity weighting was performed, with the results summarized in Table 7-9. The LRVP gasoline fueled vehicle emission increment produces a negative reactivity-weighted increment. The CNG vehicle emissions increment, while smaller than the VOC increment from gasoline fuel vehicles by more a factor of 70 , produces a small positive reactivity-weighted increment. These results are somewhat deceptive, since they reflect the domain-wide VOC contribution to potential ozone formation. Actual modeling results, which reflect the combined effect of $\mathrm{NO}_{\mathrm{x}}$ and VOC emissions increments, show a mixed impact of emissions from LRVP gasoline fuel vehicles on predicted peak ozone for 31 July. The maximum daily 1 -hour ozone concentration predicted for the LRVP scenario decreased by $4 \mathrm{ppb}$ relative to the $\mathrm{S} 1$ scenario maximum, but the domain average $1-\mathrm{hr}$ concentration increased by $2.6 \mathrm{ppb}$ for 31 July.

\subsection{Mass Budget Analysis}

The mass flux budget provides information regarding the role of initial and boundary conditions and the influence of different sources and sinks of a given chemical. It can also indicate whether a chemical is highly reactive with a short lifetime. The overall 2-day cumulative mass exchanges for selected species into and out of the modeling domain are summarized in Table 7-10. 
Table 7-10. Cumulative Domain-wide Mass Exchanges

(Fluxes, Siources, Sinks) for Selected Chemical Species Over

the Two-Day Period 30-31 July 2007

(units are tons)

\begin{tabular}{lccccccccc}
\hline & & & & Top & Side & & & & Total \\
Specie & Scenario & Net & & Flux & Flux & Deposition & Emission & Chemistry & Mass \\
\hline O3 & S1 & 507 & 2290 & -3770 & -2010 & 0 & 4000 & 7370 \\
NOX & $S 1$ & -21 & 73 & 297 & -114 & 860 & -1250 & 143 \\
VOC & S1 & -97 & 253 & -853 & 0 & 2020 & -1520 & 948 \\
BENZ & S1 & -1.4 & 5.7 & -24.7 & 0 & 16.5 & -1 & 25 \\
BENZ & LRVP & -0.5 & 5.3 & -43 & 0 & 37 & -1 & 31 \\
FORM & S1 & -16 & 24 & -65 & 0 & 7.5 & 18 & 89 \\
\hline
\end{tabular}

Note: The total mass is rounded to three significant figures and is the domain-wide total at midnight between 30 and 31 July.

For $\mathrm{O}_{3}$, the net chemical production over two days is about half of the domain-wide total mass. The net increase in the $\mathrm{O}_{3}$ mass is on the order of $5 \%$ of the total mass. The lateral export of $\mathrm{O}_{3}$ through the sides nearly equals the chemical production of $\mathrm{O}_{3}$ and is nearly twice the deposition flux. This large export is primarily outflow through the northern boundary of the modeling domain.

Relatively little $\mathrm{NO}_{\mathrm{x}}$ mass is stored in the atmosphere, resulting in very low predicted $\mathrm{NO}_{\mathrm{x}}$ concentrations in rural regions and aloft. The mlodeled $\mathrm{NO}_{\mathrm{x}}$ fluxes are several times larger than the total mass, suggesting that the turnover time of $\mathrm{NO}_{\mathrm{x}}$ within the domain is significantly less than a day. The total $\mathrm{NO}_{\mathrm{x}}$ mass is very responsive to the chemistry and lluxes through the boundaries. However, over the course of the two-day episode, the total mass decrease 1 by only 15 percent.

The chemical destruction of VCIC is $60 \%$ larger than the domain-total VOC mass. The fluxes of VOC through the top and lateral boundaries are considerably smaller than the emissions, suggesting that the boundary conditions do not affert the $\mathrm{O}_{3}$ response to VOC emission changes.

The FORM emissions are many times smaller than the total mass and the lateral fluxes, indicating that changing the FORM source term is unlikely to have much of an effect on human exposure to FORM throughout the modeling domair. The net loss over two days is about $18 \%$ of the total mass.

BENZ reacts very slowly, with 3-4\% of the total mass reacting over the course of the two-day episode. For both the $S 1$ and Gasoline scelsarios, BENZ emissions are of the same approximate size as the combined lateral and top boundary fluxes. The total mass of BENZ is also about the same size as the source term. These results indicate that most of what is being emitted is later exported out the northern boundary. 


\subsection{References}

ARB (1994). EMFAC7F model, Version 1.1. California Air Resources Board, Technical Support Division, Mobile Source Emission Inventory Branch, Sacramento, CA.

Atkinson, R. (1990). "Gas-phase Tropospheric Chemistry of Organic Compounds: A Review." Atmospheric Environment 24A, 1-41.

Atkinson, R. et al. (1994). "Formation Yields of Epoxides and O(3P) Atoms from the Gas-phase Reactions of O3 with a Series of Alkenes." International Journals of Chemical Kinetics, Vol. 26, 945-950.

Bergin, M.S.; Russell, A.G.; and Milford, J.B. (1995). Quantification of Individual VOC Reactivity Using a Chemically Detailed, Three-Dimensional Photochemical Model, Environ. Sci. Technol. 29:3029-3037.

Bischof, C., A. Carle, P. Khademi, A. Mauer, and P. Hovland (1994). ADIFOR 2.0 User's Guide. Argonne National Laboratory report ANL/MCS-TM-192.

Carter, W.P.L. and Atkinson, R. (1989). "Computer Modeling Study of Incremental Hydrocarbon Reactivity." Environ. Sci. Technol. (23) pp 864-880.

Carter, W.P.L. (1990). "A Detailed Mechanism for the Gas-Phase Atmospheric Reactions of Organic Compounds." Atmos. Environ. (24A:3); pp. 481-518.

Carter, W.P.L. (1994). "Development of Ozone Reactivity Scales for Volatile Organic Compounds," J. Air and Waste Manage. Assoc., 44: 881-899.

Carter, W.P.L. (1995). “Atmospheric Process Evaluation of Mobile Source Emissions", Environ. Sci. Technol.

Chang, Y.T. and Rudy, S.J. (1990). "Ozone-Forming Potential of Organic Emissions from AlternativelyFueled Vehicles." Atmos. Environ. (24A:9); pp. 2421-2430.

Department of Natural Resources (November 1994). The 1994 State Implementation Plan for the Atlanta Ozone Nonattainment Area. Prepared by the Air Protection Branch. Atlanta, GA: Georgia Dept. of Natural Resources, Environmental Protection Division.

Emigh, R.A., and J.G. Wilkinson (1995). The Emissions Modeling System (EMS-95) User's Guide.

Gery, M.W., G.Z.Whitten, J.P. Killus and M.C. Dodge (1989). A Photo Chemical Mechanism for Urban and Regional-scale Computer Modeling, J. Geophys. Res. 94: 12925-56.

Harley, R.A., and G.R. Cass (1994). Modeling the Concentrations of Gas-Phase Toxic Organic Air Pollutants: Direct Emissions and Atmospheric Formation, Environ. Sci. Technol., 28, 88-98.

Kelly, N.A. and Groblicki, P.J. (1993). "Real-World Emissions from a Modern Production Vehicle Driven in Los Angeles," Journal of the Air and Waste Management Association, 43:1351. 
Killus, J.P. (1996). Development and Testing of a Toxics Version of the Carbon Bond 4 Mechanism. Technical memorandum to Radian Co, Sacramento, CA 95827.

Ligocki, M.P. and Whitten, G.Z. (1992). "Modeling of Air Toxics with the Urban Airshed Model (UAM)" Presented at the 85th Annual Meeting and Exhibition, Air and Waste Management Association, Kansas City, MO. 92-84.12.

Moortgat, G.; Veryet, B; and Lesclaux, R. (1989). "Absorption Spectrum and Kinetics of Reactions of the Acetylperoxy Radical." J. Phys. Chem., Vol. 93, pp. 2362-2368.

Morris, R.E. and Myers, T.C. (June 1990). User's Guide For the Urban Airshed Model, Volume I: User's Manual for UAM (CB-IV). EF'A-450/4-90-007A. Work performed by Systems Applications, Inc., San Rafael, CA. Research Triangle Park, NC: U.S. Environmental Protection Agency, Office of Air Quality Planning and Standards.

Pollack, A.K., J.P. Cohen, J.L. Fieber, R.E. Morris, and G. Yarwood (1993). Methodology for Modeling the Air Quality Impacts of Changing the Composition of Drels Used in Light-Duty Gasoline Vehicles, Auto/Oil Air Quality Improvement Research Program, Phase I, Final Report, Systems Applications International, San Rafael, California.

Reichhart, T. (1995). "A New F ormula for Fighting Urban Smog." Environ. Sci. Technol. (29:1); pp. 36A$41 \mathrm{~A}$.

Russell, A.G., L.A. McNair, M.I.. Odman, and N. Kumar (1991). Organic Compound Reactivities and the Use of Alternative Fuels, Draft Final Report to the California Air Resource Board.

SCAQMD (1994). 1994 Air Quality Management Plan: Meeting the Clean Air Challenge. South Coast Air Quality Management District, [liamond Bar, CA.

U.S. DOE (1994). Emissions of Greenhouse Gases in the United States 1987-1992. DOE/EIA-0573, Department of Energy, Energy Information Administration, Office of Energy Markets and End Use, Washington, DC.

U.S. EPA (1993). MOBILE5: Emission Factor Model, Version Date March 23, 1993. United States Environmental Protection Agency, Office of Mobile Sources, Ann Arbor, MI.

U.S. EPA (1995). "State Workbjok for Estimating Greenhouse Gas Emissions, Second Edition." EPA-230B-95-001, U.S. Environmental ?.rotection Agency, Office of Planning and Evaluation.

Yang, Yueh-Jiun et al. (1997). F'ast Sensitivity Analysis of Three-Dimensinnal Photochemical Models, $22^{\text {nd }}$ NATO/CCMS International Technical Meeting on Air Pollution Modeling and its Application. 